\title{
PORTSMOUTH GASEOUS DIFFUSION PLANT ANNUAL SITE ENVIRONMENTAL REPORT FOR 1993
}

\author{
Project director \\ F. C. Kornegay
}

\author{
Project coordinator \\ D. C. West \\ Technical coordinator \\ S. C. Newman \\ Coordinating editor \\ C. M. Horak
}

Date Published: November 1994

Prepared by

Environmental, Safety, and Health Compliance and Environmental Management staffs

MARTIN MARIETTA ENERGY SYSTEMS, INC.

P.O. Box 2008

Oak Ridge, Tennessee 37831-6285

and the

Environmental Control Department

Portsmouth Gaseous Diffusion Plant

MARTIN MARIETTA ENERGY SYSTEMS, INC.

P.O. Box 628

Piketon, Ohio 45661

for the

U.S. DEPARTMENT OF ENERGY

under contract No. DE-AC05-840R21400

and

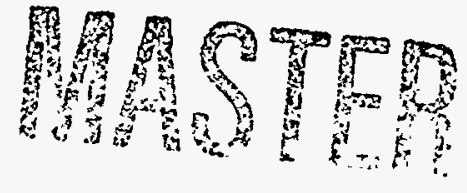

MARTIN MARIETTA UTILITY SERVICES, INC. for the

UNITED STATES ENRICHMENT CORPORATION under contract No. DE-AC05-76OR00001 
. 


\section{DISCLAIMER}

This report was prepared as an account of work sponsored by an agency of the United States Government. Neither the United States Government nor any agency thereof, nor any of their employees, make any warranty, express or implied, or assumes any legal liability or responsibility for the accuracy, completeness, or usefulness of any information, apparatus, product, or process disclosed, or represents that its use would not infringe privately owned rights. Reference herein to any specific commercial product, process, or service by trade name, trademark, manufacturer, or otherwise does not necessarily constitute or imply its endorsement, recommendation, or favoring by the United States Government or any agency thereof. The views and opinions of authors expressed herein do not necessarily state or reflect those of the United States Government or any agency thereof. 


\section{DISCLAIMER}

Portions of this document may be illegible in electronic image products. Images are produced from the best available original document. 


\section{Contents}

Page

List of Figures $\ldots \ldots \ldots \ldots \ldots \ldots \ldots \ldots \ldots \ldots \ldots \ldots \ldots \ldots \ldots \ldots \ldots \ldots \ldots \ldots \ldots$

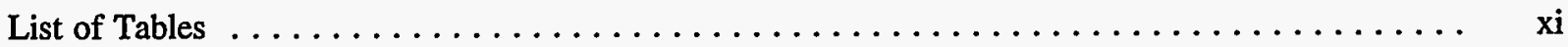

Executive Summary $\ldots \ldots \ldots \ldots \ldots \ldots \ldots \ldots \ldots \ldots \ldots \ldots \ldots \ldots \ldots \ldots \ldots \ldots \ldots \ldots \ldots$

Acronyms and Abbreviations $\ldots \ldots \ldots \ldots \ldots \ldots \ldots \ldots \ldots \ldots \ldots \ldots \ldots \ldots \ldots \ldots \ldots \ldots \ldots \ldots$

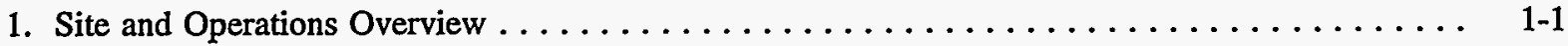

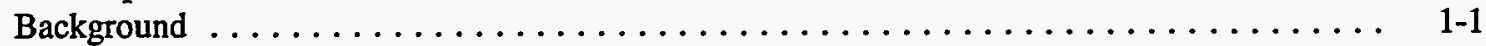

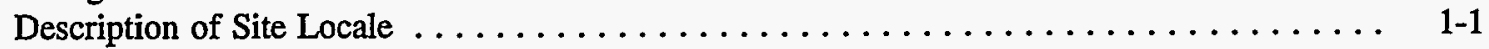

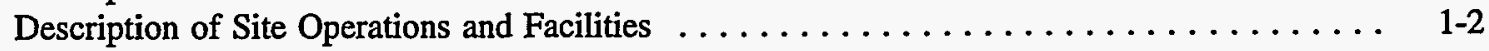

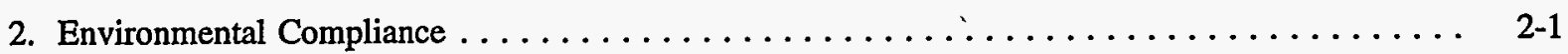

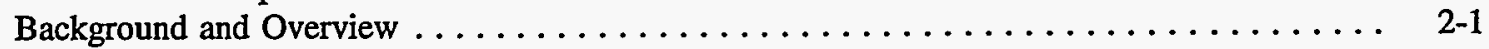

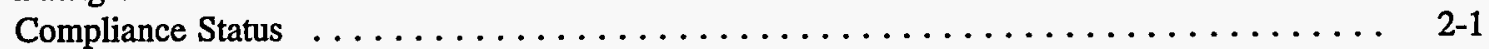

Resource Conservation and Recovery Act (RCRA) ................ 2-1

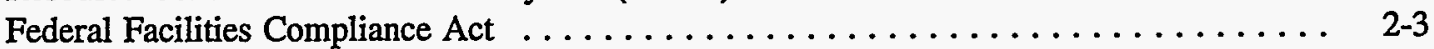

Comprehensive Environmental Response, Compensation, and

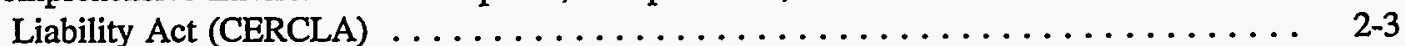

Superfund Amendments and Reauthorization Act (SARA), Title III $\ldots \ldots \ldots \ldots \ldots$ 2-3

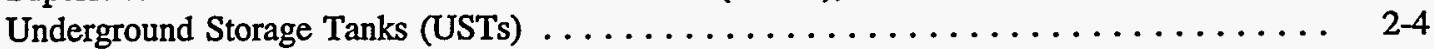

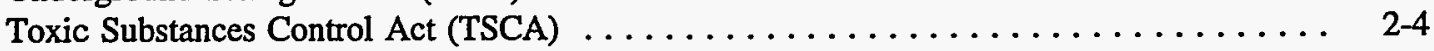

Federal Insecticide, Fungicide, and Rodenticide Act $\ldots \ldots \ldots \ldots \ldots \ldots \ldots \ldots \ldots \ldots \ldots \ldots \ldots$

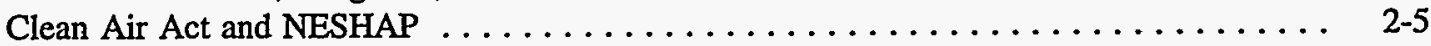

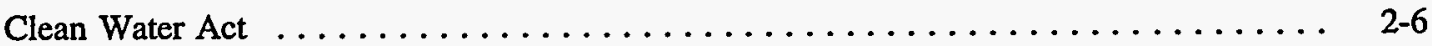

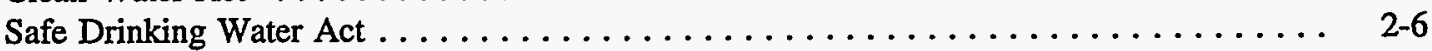

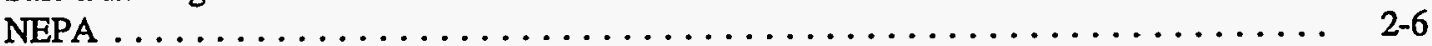

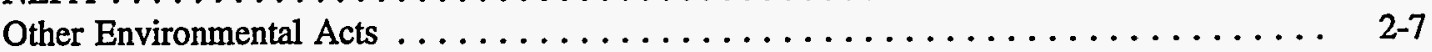

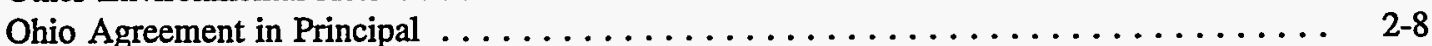

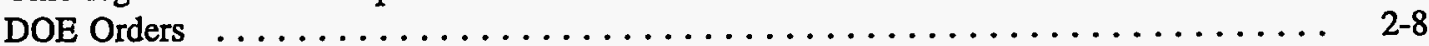

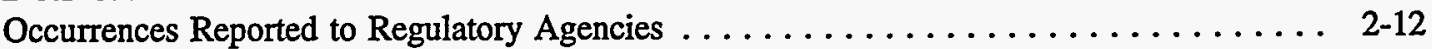

Compliance Audits of Environmental Programs . . . . . . . . . . .

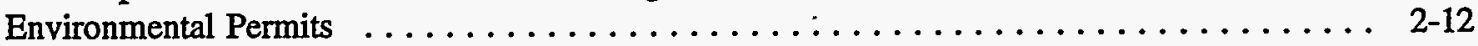

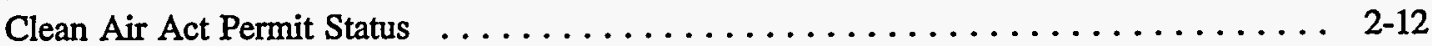

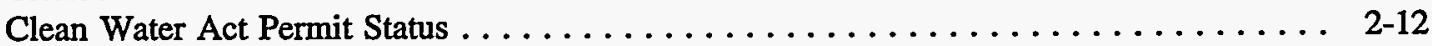

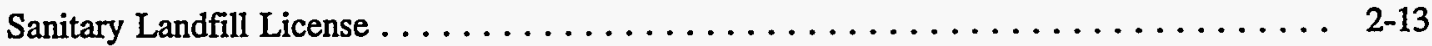

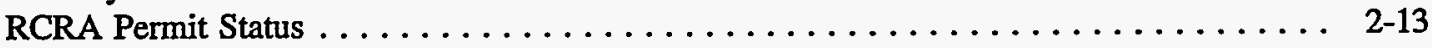

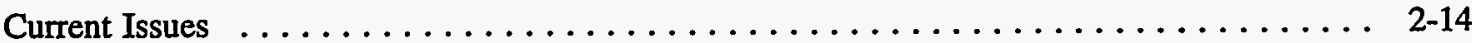

RCRA NOVs ................................... 2-14

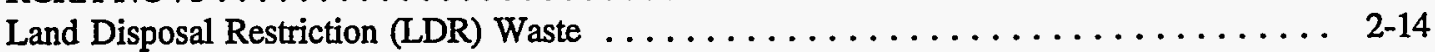

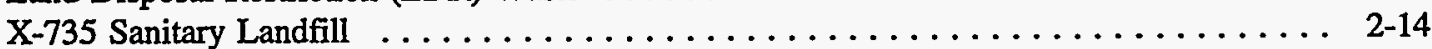

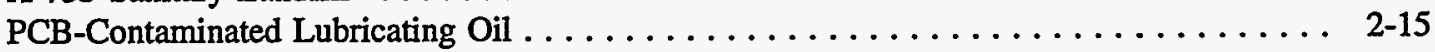

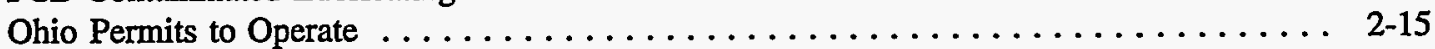

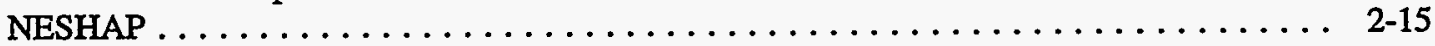

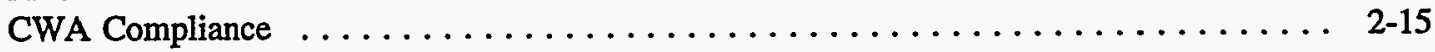

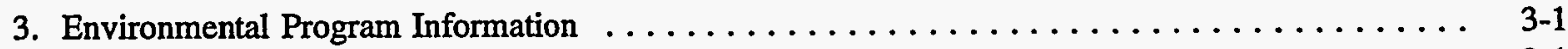

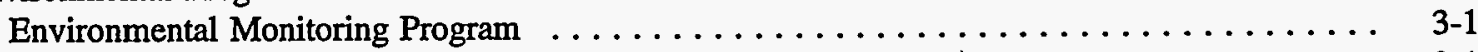

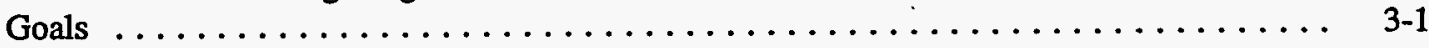


Rationale . . . . . . . . . . . . . . . . . . . . . . . .

Environmental Monitoring Program Changes in $1993 \ldots \ldots \ldots \ldots \ldots \ldots \ldots \ldots$

Environmental Quality . . . . . . . . . . . . . . . . . . . . . . . .

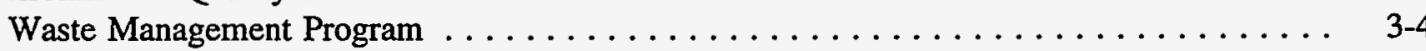

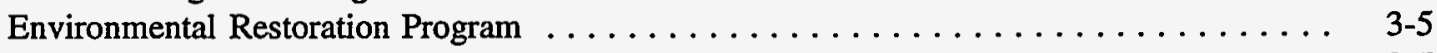

Waste Minimization and Pollution Prevention Program $\ldots \ldots \ldots \ldots \ldots \ldots \ldots \ldots . . \ldots \ldots$

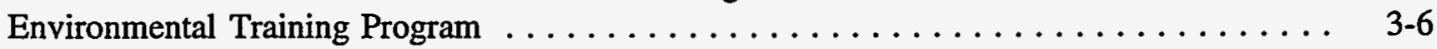

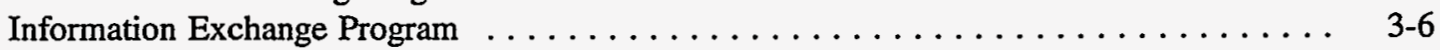

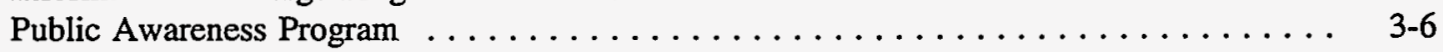

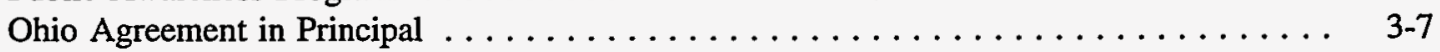

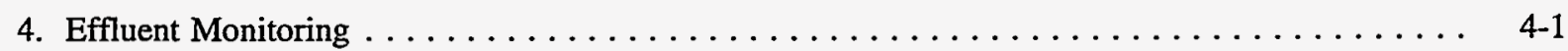

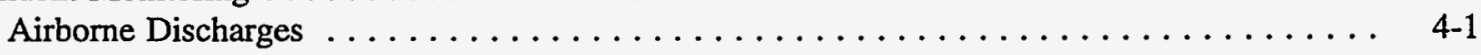

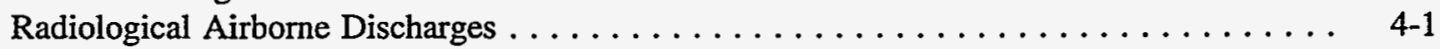

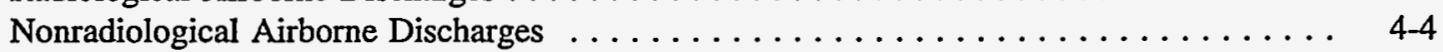

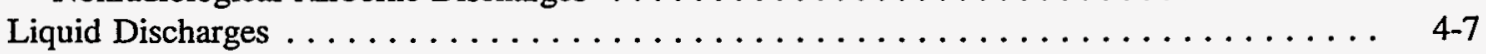

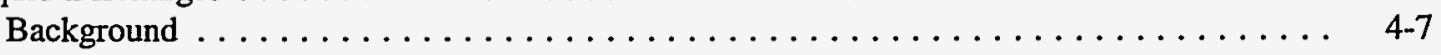

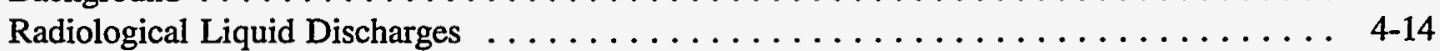

Nonradiological Liquid Discharges $\ldots \ldots \ldots \ldots \ldots \ldots \ldots \ldots \ldots \ldots \ldots \ldots .4 .17$

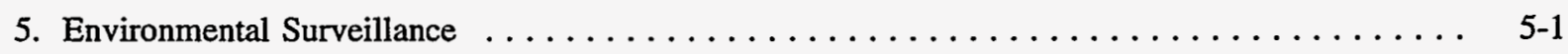

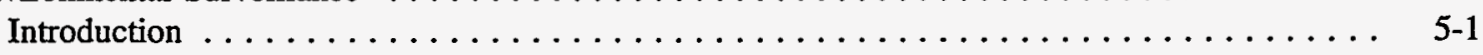

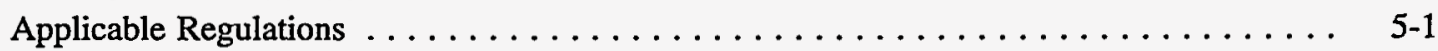

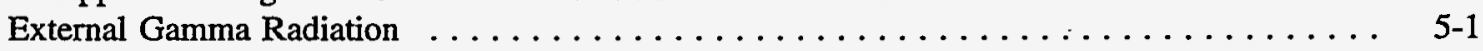

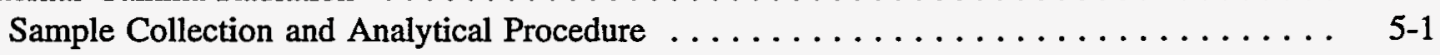

Results .................................. $5-4$

Ambient Air . . . . . . . . . . . . . . . . . . . .

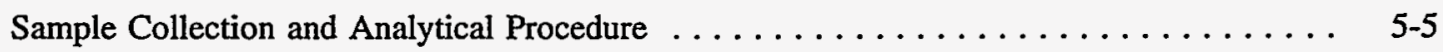

Results ............................ $5-7$

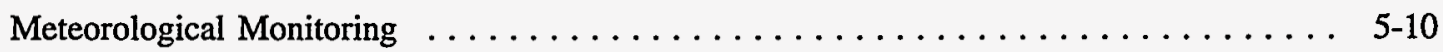

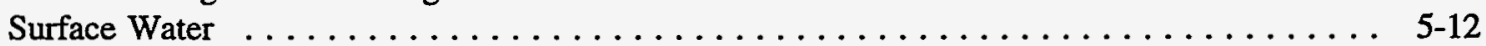

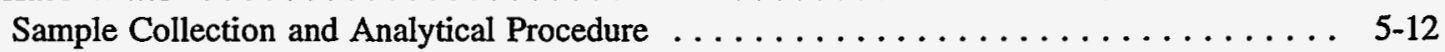

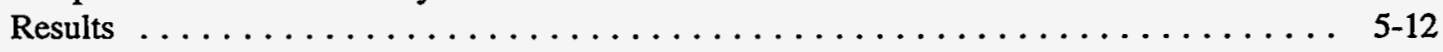

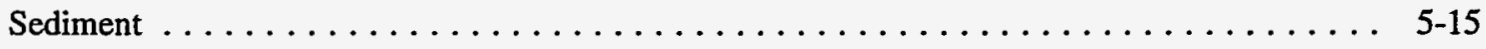

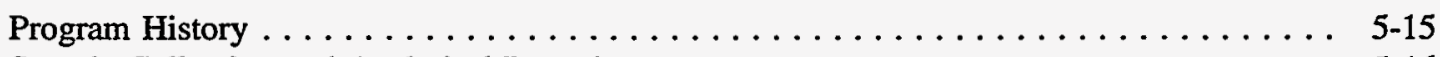

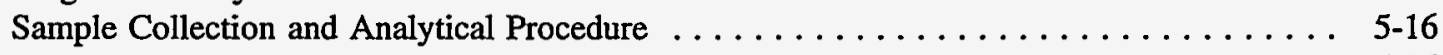

Results ................................. 5-16

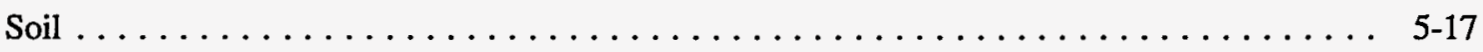

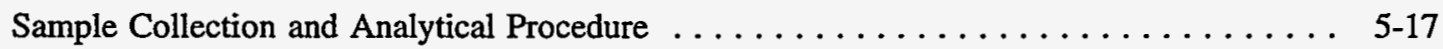

Results ................................. 5-19

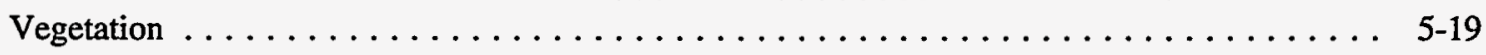

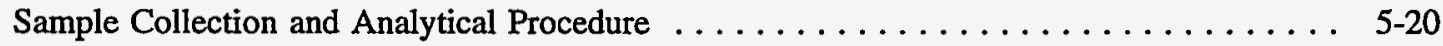

Results ............................ 5-20

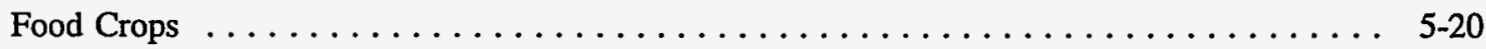

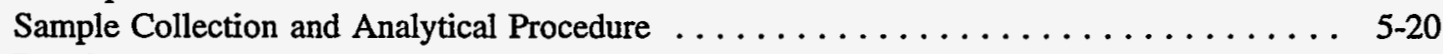

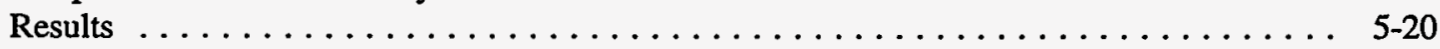

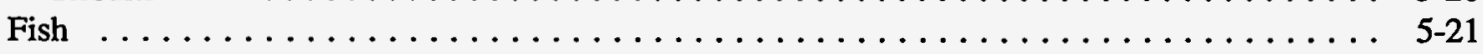

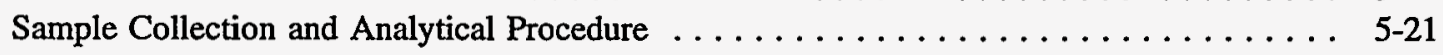

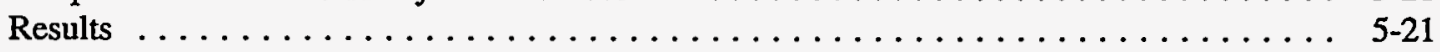

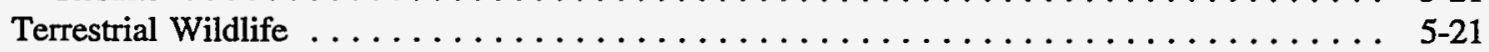

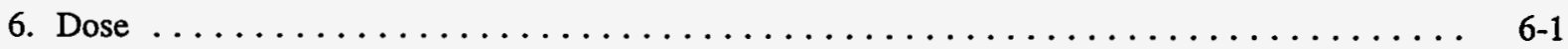

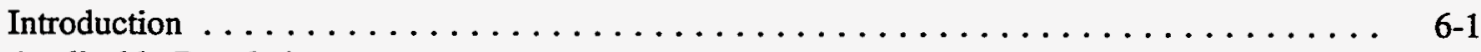

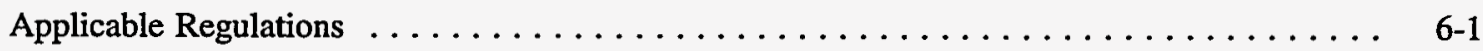

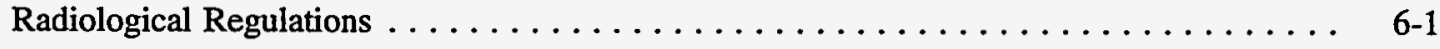




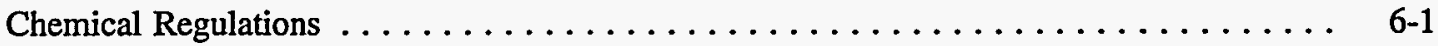

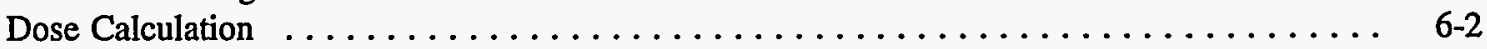

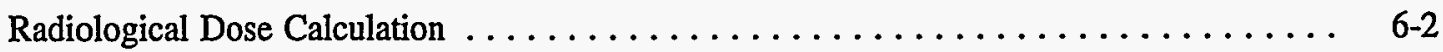

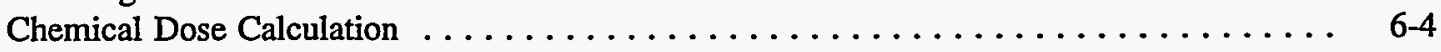

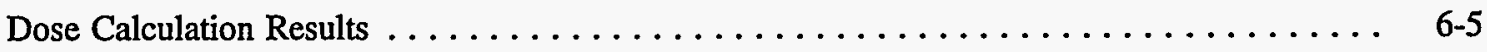

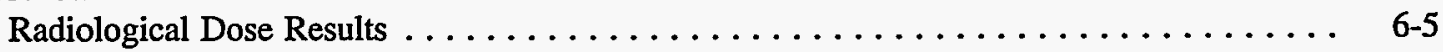

Chemical Dose Results .......................... 6-6

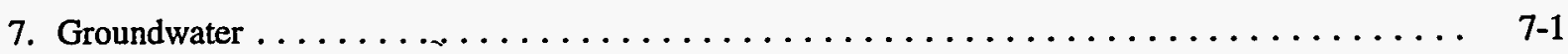

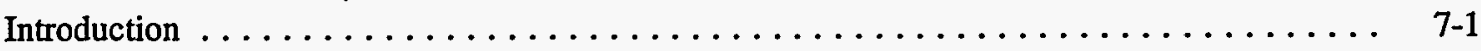

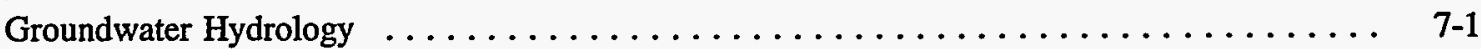

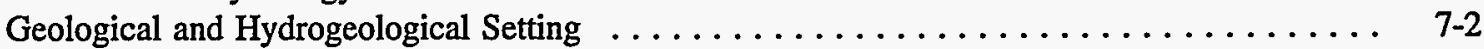

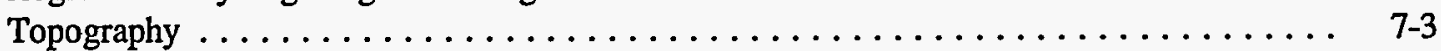

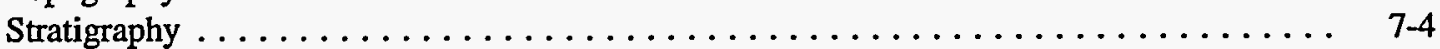

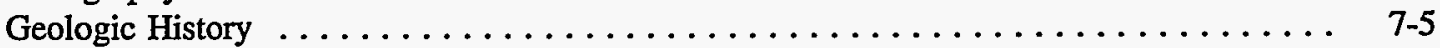

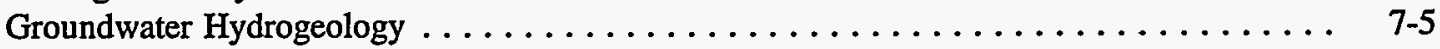

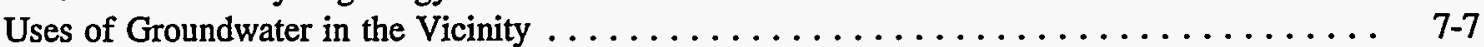

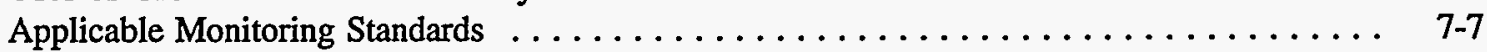

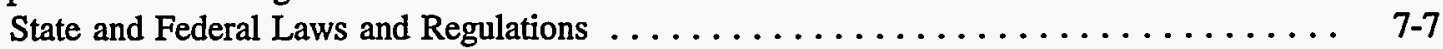

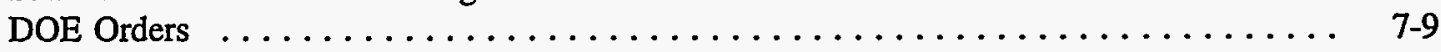

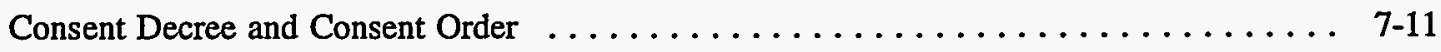

Guidance Documents . . . . . . . . . . . . . . .

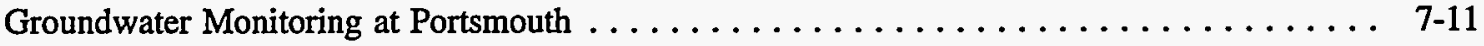

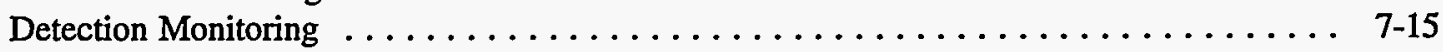

Assessment Monitoring . . . . . .

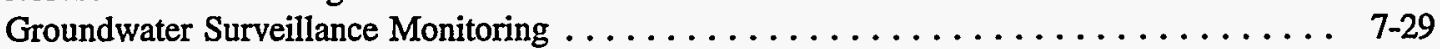

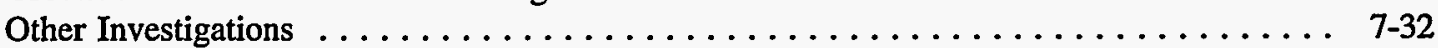

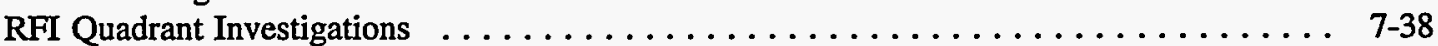

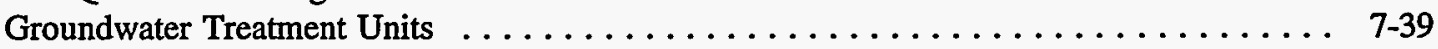

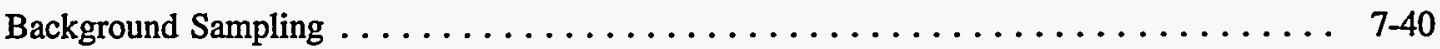

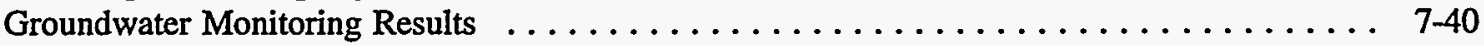

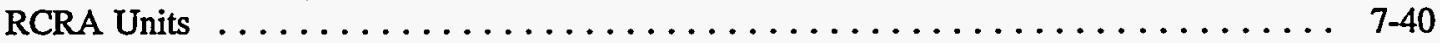

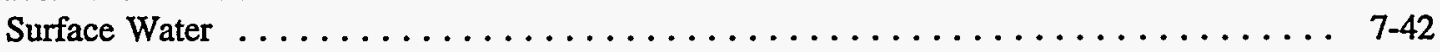

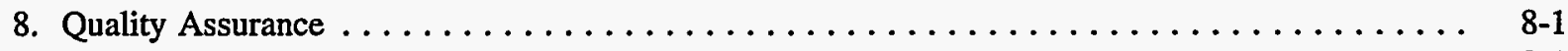

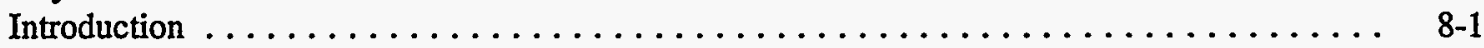

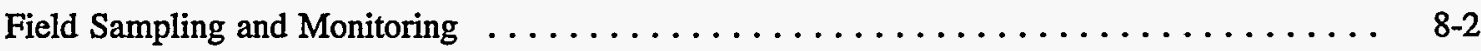

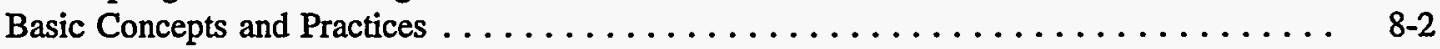

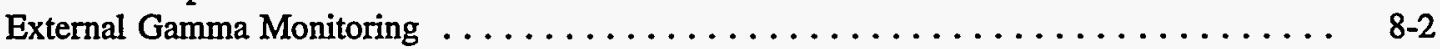

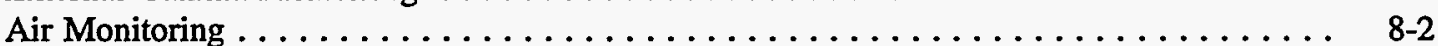

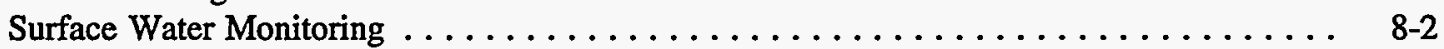

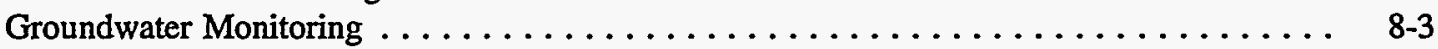

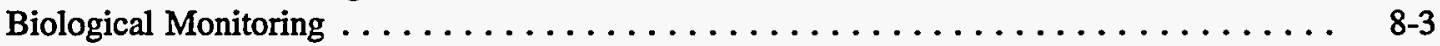

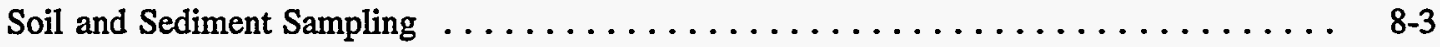

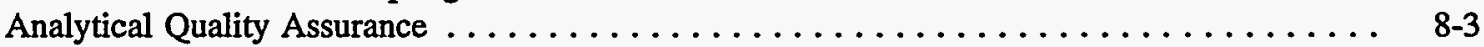

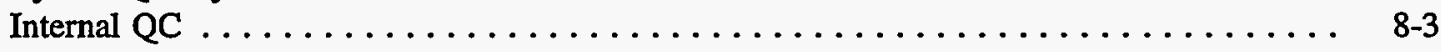

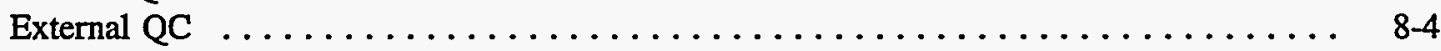

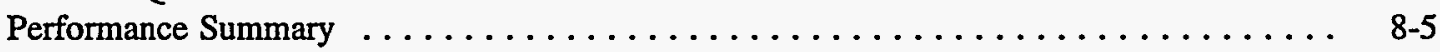

9. Unusual Occurrences and Special Studies . . . . . . . . . . . .

Portsmouth Gaseous Diffusion Plant Spill Report ................. 9-1

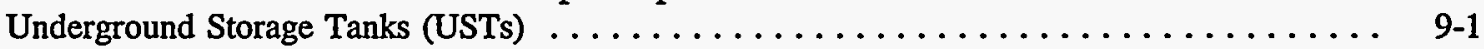


National Pollutant Discharge Elimination System (NPDES)

Treatment Bypass at the X-624 Groundwater Treatment Facility $\ldots \ldots \ldots \ldots \ldots \ldots .9-2$

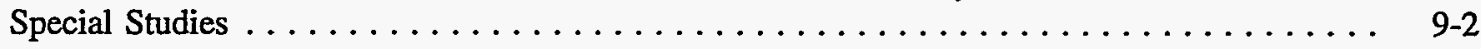

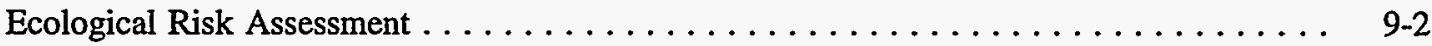

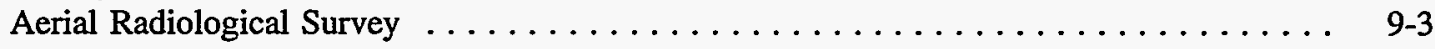

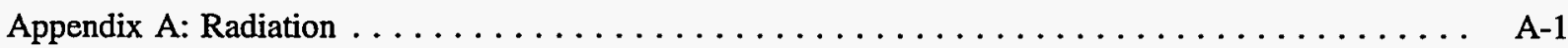

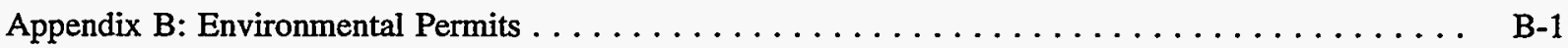

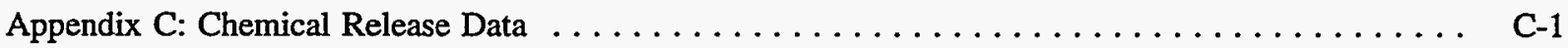

Appendix D: Radionuclide and Chemical Nomenclature $\ldots \ldots \ldots \ldots \ldots \ldots \ldots \ldots \ldots \ldots \ldots \ldots \ldots$

Appendix E: Errata for the Portsmouth Gaseous Diffusion Plant Environmental

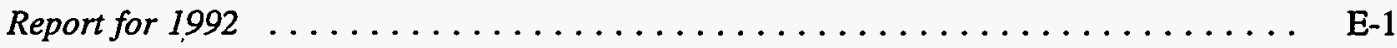

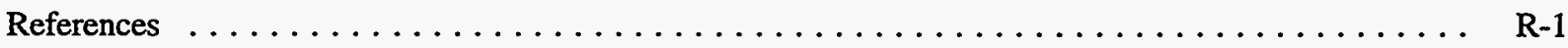

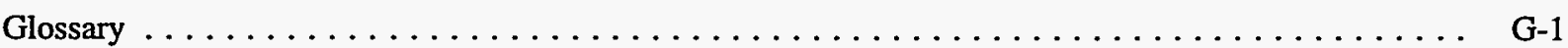




\section{List of Figures}

Figure

Page

1 Airborne radionuclides discharged at Portsmouth, $1989-1993 \ldots \ldots \ldots \ldots \ldots \ldots \ldots$ xiv

2 Waterborne radionuclides discharged at Portsmouth, $1989-1993 \ldots \ldots \ldots \ldots \ldots \ldots \ldots$ xv

$3 \quad$ NPDES compliance at Portsmouth, $1989-1993 \ldots \ldots \ldots \ldots \ldots \ldots \ldots \ldots \ldots \ldots \ldots \ldots$

4 Maximum predicted individual EDEs from airborne radionuclides, $1989-1993 \ldots \ldots \ldots$. . . xix

5 Maximum predicted individual EDEs from waterborne radionuclides, 1989-1993 . . . . . . xix

Location of the Portsmouth site within the state of Ohio $\ldots \ldots \ldots \ldots \ldots \ldots \ldots \ldots$

Location of the Portsmouth site in relation to the geographic region $\ldots \ldots \ldots \ldots \ldots$

4.1 Total curies of uranium discharged to air $\ldots \ldots \ldots \ldots \ldots \ldots \ldots \ldots \ldots \ldots$

4.2 Total kilograms of uranium discharged to air $\ldots \ldots \ldots \ldots \ldots \ldots \ldots \ldots \ldots$

4.3 Total curies of technetium discharged to air $\ldots \ldots \ldots \ldots \ldots \ldots \ldots \ldots \ldots \ldots \ldots$

4.4 Major wastewater sources and systems at Portsmouth $\ldots \ldots \ldots \ldots \ldots \ldots \ldots \ldots$

4.5 NPDES water sampling locations at Portsmouth $\ldots \ldots \ldots \ldots \ldots \ldots \ldots \ldots \ldots$

4.6 Flow diagram for outfall $001(\mathrm{X}-230 \mathrm{~J}-7$ east holding pond $) \ldots \ldots \ldots \ldots \ldots \ldots$

4.7 Flow diagram for outfalls 002 and $602(\mathrm{X}-230 \mathrm{~K}$ south holding pond

and $\mathrm{X}-621$ coal-pile treatment plant) $\ldots \ldots \ldots \ldots \ldots \ldots \ldots \ldots \ldots \ldots \ldots \ldots \ldots \ldots \ldots \ldots \ldots$

4.8 Flow diagram for outfalls 003, 604, and 605 (X-6619 sewage treatment plant,

$\mathrm{X}-700$ biodenitrification plant, and X-705 waste treatment facility) $\ldots \ldots \ldots \ldots \ldots$ 4-12

4.9 Flow diagram for outfall 004 (X-616 chromate treatment facility and

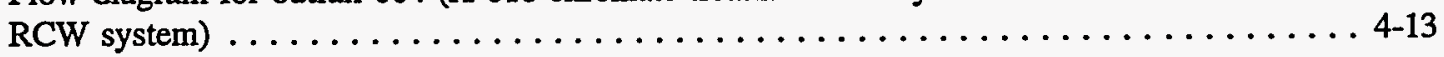

4.10 Flow diagram for outfalls $005,006,007$, and $008(\mathrm{X}-611 \mathrm{~B}$ sludge

lagoon and X-611A north, middle, and south sludge lagoons) $\ldots \ldots \ldots \ldots \ldots \ldots \ldots$-13

Flow diagram for outfall 009 (X-230L north holding pond $) \ldots \ldots \ldots \ldots \ldots \ldots$

4.12 Flow diagram for outfall 010 (X-230J-5 northwest holding pond $\ldots \ldots \ldots \ldots \ldots \ldots$ 4-14

4.13 Flow diagram for outfall 011 (X-230J-6 northeast holding pond $) \ldots \ldots \ldots \ldots \ldots$

Flow diagram for outfalls 012 and $013(\mathrm{X}-2230 \mathrm{M}$ holding pond and $\mathrm{X}-2230 \mathrm{~N}$
holding pond $)$ and the drainage sector designated as outfall $014 \ldots \ldots \ldots \ldots \ldots \ldots$

4.15 Total curies of uranium discharged to surface water $\ldots \ldots \ldots \ldots \ldots \ldots \ldots \ldots$

4.16 Total kilograms of uranium discharged to surface water $\ldots \ldots \ldots \ldots \ldots \ldots \ldots \ldots \ldots$ 
4.17 Total curies of technetium discharged to surface water $\ldots \ldots \ldots \ldots \ldots \ldots \ldots \ldots \ldots$

4.18 Total curies of uranium daughters $\left({ }^{231} \mathrm{Th},{ }^{234} \mathrm{Th}\right.$, and $\left.{ }^{234 m} \mathrm{~Pa}\right)$ discharged

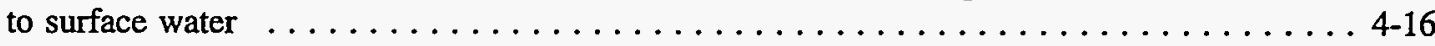

$5.1 \quad$ Off-site TLD locations (Site Group II) at Portsmouth $\ldots \ldots \ldots \ldots \ldots \ldots \ldots \ldots \ldots$

$5.2 \quad$ On-site TLD locations (Site Group I) at Portsmouth $\ldots \ldots \ldots \ldots \ldots \ldots \ldots \ldots \ldots$

5.3 Average annual external gamma exposure on and around the Portsmouth site, for the state of Ohio, and for the United States as a whole $\ldots \ldots \ldots \ldots \ldots \ldots \ldots$. $5-5$

5.4 External cosmic, terrestrial, and total gamma exposure for several states

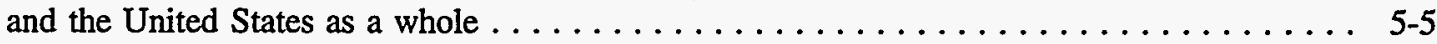

5.5 On-site monitoring and meteorological tower locations at Portsmouth $\ldots \ldots \ldots \ldots \ldots$ 5-6

$5.6 \quad$ Off-site air monitoring locations at Portsmouth $\ldots \ldots \ldots \ldots \ldots \ldots \ldots \ldots \ldots \ldots \ldots$

5.7 Wind rose (10-m level) showing wind speed frequency distribution data (with $90.2 \%$ of possible data) used for 1993 estimates $\ldots \ldots \ldots \ldots \ldots \ldots \ldots \ldots \ldots \ldots \ldots \ldots$

5.8 Wind rose (40-m level) showing wind speed frequency distribution data (with $90.9 \%$ of possible data) used for 1993 estimates $\ldots \ldots \ldots \ldots \ldots \ldots \ldots \ldots \ldots .11$

5.9 Routine surface water sampling locations (non-NPDES) at Portsmouth $\ldots \ldots \ldots \ldots \ldots$-12

$5.10 \quad$ Stream sediment sampling locations at Portsmouth $\ldots \ldots \ldots \ldots \ldots \ldots \ldots \ldots \ldots$

5.11 Internal soil sampling locations at Portsmouth (Group IA) $\ldots \ldots \ldots \ldots \ldots \ldots \ldots$

5.12 On-site soil and vegetation sampling locations at Portsmouth (Group I) $\ldots \ldots \ldots \ldots$ 5-18

5.13 Off-site soil and vegetation sampling locations for Portsmouth (Group II) $\ldots \ldots \ldots \ldots$ 5-18

5.14 Remote soil and vegetation sampling locations for Portsmouth (Group III) . . . . . . . 5-19

$7.1 \quad$ Typical monitoring well construction $\ldots \ldots \ldots \ldots \ldots \ldots \ldots \ldots \ldots \ldots \ldots \ldots \ldots \ldots \ldots \ldots$

7.2 Schematic cross section of the Portsmouth site $\ldots \ldots \ldots \ldots \ldots \ldots \ldots \ldots \ldots \ldots$

7.3 Portsmouth RCRA interim status land disposal unit locations $\ldots \ldots \ldots \ldots \ldots \ldots \ldots$ 7-12

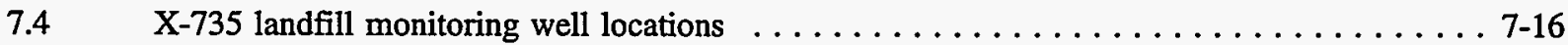

7.5 X-701C neutralization pit monitoring well locations $\ldots \ldots \ldots \ldots \ldots \ldots \ldots \ldots \ldots \ldots \ldots$

7.6 Site-wide surface water monitoring locations $\ldots \ldots \ldots \ldots \ldots \ldots \ldots \ldots \ldots \ldots \ldots$

$7.7 \quad \mathrm{X}-701 \mathrm{~B}$ holding pond-extent of trichloroethylene concentration, 4th quarter $1993 \ldots \ldots 7-21$

7.8 X-749 south contaminated materials storage yard-extent of trichloroethylene

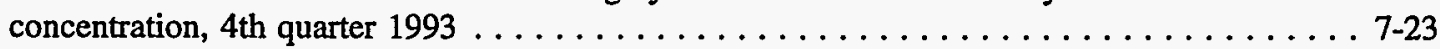

$7.9 \quad \mathrm{X}-231 \mathrm{~B}$ southwest oil biodegradation plot monitoring well locations $\ldots \ldots \ldots \ldots \ldots \ldots 7-26$ 
7.10 X-616 chromium sludge surface impoundments-extent of chromium (SW846/Diss.) concentration, 1st quarter 1993

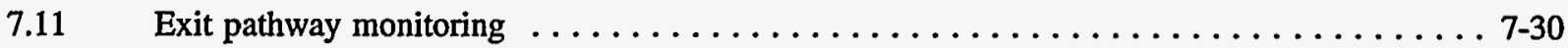

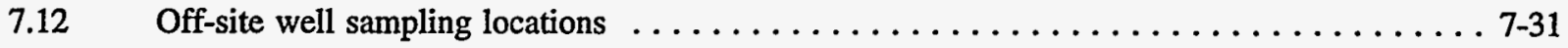

7.13 Portsmouth water supply well field sampling $\ldots \ldots \ldots \ldots \ldots \ldots \ldots \ldots \ldots \ldots .7 .33$

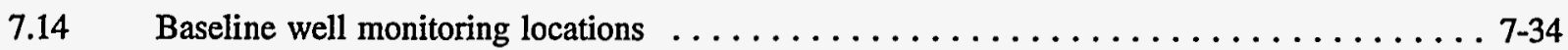

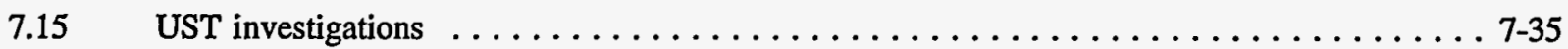

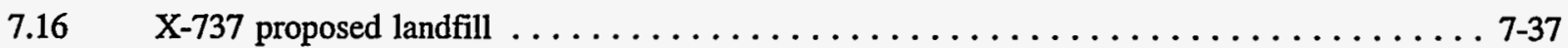

A.1 Isotopes of the element hydrogen $\ldots \ldots \ldots \ldots \ldots \ldots \ldots \ldots \ldots \ldots \ldots \ldots \ldots \ldots \ldots \ldots \ldots . .1$

A.2 Penetrating power of radiation $\ldots \ldots \ldots \ldots \ldots \ldots \ldots \ldots \ldots \ldots \ldots \ldots \ldots \ldots \ldots \ldots \ldots \ldots$

A.3 Possible radiation pathways $\ldots \ldots \ldots \ldots \ldots \ldots \ldots \ldots \ldots \ldots \ldots \ldots \ldots \ldots \ldots \ldots \ldots \ldots \ldots$ 



\section{List of Tables}

Table

Page

$2.1 \quad$ RCRA closure status at Portsmouth for $1993 \ldots \ldots \ldots \ldots \ldots \ldots \ldots \ldots \ldots \ldots \ldots \ldots \ldots$

2.2 Environmental audits and inspections during $\mathrm{CY} 1993 \ldots \ldots \ldots \ldots \ldots \ldots \ldots \ldots \ldots \ldots$

2.3 Portsmouth environmental permits $\ldots \ldots \ldots \ldots \ldots \ldots \ldots \ldots \ldots \ldots \ldots \ldots \ldots \ldots \ldots \ldots \ldots$

$4.1 \quad 1993$ Portsmouth radionuclide releases to air $\ldots \ldots \ldots \ldots \ldots \ldots \ldots \ldots \ldots \ldots$

4.2 Portsmouth radionuclide releases to surface water in $1993 \ldots \ldots \ldots \ldots \ldots \ldots$

5.1 Ambient gamma radiation levels and doses at Portsmouth for $1993 \ldots \ldots \ldots \ldots \ldots$

5.2 Gross alpha concentrations in ambient air at Portsmouth for $1993 \ldots \ldots \ldots \ldots \ldots \ldots$

5.3 Gross beta-gamma concentrations in ambient air at Portsmouth for $1993 \ldots \ldots \ldots$. . . . 5-9

5.4 Total gaseous fluoride concentrations (as HF) in ambient air at

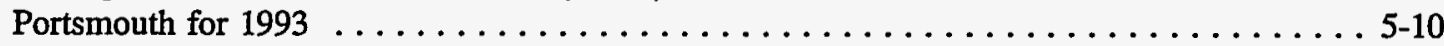

5.5 Uranium in water samples at Portsmouth for $1993 \ldots \ldots \ldots \ldots \ldots \ldots \ldots \ldots \ldots$

5.6 Gross alpha radioactivity in water samples at Portsmouth for $1993 \ldots \ldots \ldots \ldots$. . . . 5

5.7 Technetium-99 concentrations in water samples at Portsmouth for $1993 \ldots \ldots \ldots \ldots$. . . . 5-14

5.8 Gross beta radioactivity in water samples at Portsmouth for $1993 \ldots \ldots \ldots \ldots \ldots$. . . . 14

6.1 Summary of estimated committed effective dose equivalent (CEDE)

to an adult at locations of maximum exposure $\ldots \ldots \ldots \ldots \ldots \ldots \ldots \ldots \ldots \ldots \ldots \ldots$

6.2 Summary of CDI/ADI ratios exceeding 1 in $1993 \ldots \ldots \ldots \ldots \ldots \ldots \ldots \ldots$

7.1 Stratigraphy in the vicinity of the Portsmouth facility $\ldots \ldots \ldots \ldots \ldots \ldots \ldots \ldots$

7.2 Analyte analysis required for groundwater monitoring at RCRA units, the sanitary landfill, surface water locations, off-site locations, and the

X-701C neutralization pit . . . . . . . . . . . . .

A.1 Comparison and description of various dose levels $\ldots \ldots \ldots \ldots \ldots \ldots \ldots \ldots \ldots$

B.1 Portsmouth environmental permits as of March $30,1994 \ldots \ldots \ldots \ldots \ldots \ldots \ldots \ldots$ B-1

C.1 Portsmouth Gaseous Diffusion Plant chemical releases for $1993 \ldots \ldots \ldots \ldots \ldots \ldots \ldots$ C-1 
$\ldots$

$\ldots$ 


\section{Executive Summary}

\section{SCOPE AND PURPOSE}

This calendar year (CY) 1993 annual report on environmental monitoring of the U.S. Department of Energy's (DOE's) Portsmouth Gaseous Diffusion Plant (Portsmouth) and its environs consists of three separate documents: a summary pamphlet for the general public; a more detailed discussion of compliance status, data, and environmental impacts (this document); and a volume of detailed data that is available on request. The

objectives of this report are to

- report compliance status during 1993 ,

- provide information about the plant site and plant operations,

- report 1993 monitoring data for the installation and its environs that may have been affected by operations on the plant site,

- document information on input and assumptions used in calculations,

- provide trend analyses (where appropriate) to indicate increases and decreases in environmental impact, and

- provide general information on quality assurance for the environmental monitoring program.

\section{Compliance Status}

Several federal, state, and local agencies are responsible for enforcing environmental regulations at Portsmouth. As of July 1, 1993, responsibility for ensuring compliance was split between DOE, as site owner and operator of waste management and environmental remediation projects, and the United States Enrichment Corporation (USEC), a government-owned corporation formed by the National Energy Policy Act of 1992 to take over the U.S. uranium enrichment business. The management contractor for DOE is Martin Marietta Energy Systems, Inc., and a new subsidiary, Martin Marietta Utility Services, Inc., was formed to provide management services for USEC. The Nuclear Regulatory Commission (NRC) is scheduled to assume direct oversight of USEC operations in October 1995. In the interim, DOE is providing oversight of NRC-regulated activities.

Although much progress has been made toward achieving full regulatory compliance at Portsmouth, much remains to be accomplished. Ongoing self-assessments of compliance status and implementation of corrective actions continue to identify environmental issues. These issues are discussed openly with regulatory agencies and the public to ensure that compliance with all environmental regulations will be attained.

In 1993, two notices of violation (NOVs) were issued by the Ohio Environmental Protection Agency (OEPA), and an additional NOV was issued by the U.S. Environmental Protection Agency (USEPA) Region V. These NOVs are summarized in the following.

The OEPA cited Portsmouth for five violations identified in the annual Resource Conservation and Recovery Act (RCRA) compliance audit. All five of these violations were corrected at the time of the audit. In addition, this NOV reiterated five outstanding violations from previous audits. These violations involved tanks in X-700, $\mathrm{X}-740$, and X-750, all of which were undergoing RCRA closure at the time of the audit, and the RCRA status of depleted uranium hexafluoride $\left(\mathrm{UF}_{6}\right)$ stored on-site, which is being debated between DOE and the OEPA.

The other NOV was received from the OEPA for failure to notify and gain approval from the OEPA to refrain from installing a backup pump in each sump of the X-701B trench intercept system as shown in the approved work plan, failure to conduct all of the groundwater monitoring tasks as outlined in the approved work plan for X-701B, and failure to operate and maintain the X-701B trench intercept system and X-231B as per their approved work plans.

The NOV received from the USEPA disapproved the revised Air RFI (RCRA facility investigation) Work Plan and the Quality Assurance Project Plan. 


\section{RADIONUCLIDE AND CHEMICAL RELEASES}

Environmental monitoring systems at Portsmouth include emission monitoring networks for air and surface water discharges. Specific emission monitoring networks include

- a network of 14 continuous vent samplers on the major radionuclide and fluoride emission sources,

- continuous opacity monitors on the Portsmouth coal-fired steam boilers and laboratory analysis of all coal deliveries, and

- a network of 14 sampling locations for plant discharges to local surface waters plus 7 sampling locations for internal discharges (i.e., processes that discharge to other monitored discharge locations).

\section{Airborne Discharges}

The release of pollutants into the atmosphere from numerous point and non-point sources at the Portsmouth facility is regulated by permits from the state of Ohio and the USEPA. These pollutants include standard industrial pollutants such as smoke, fly ash, sulfur dioxide $\left(\mathrm{SO}_{2}\right)$, gaseous fluorides, gasoline and diesel fuel vapors, cleaning solvent vapors, and process coolants (chlorofluorocarbons, or CFCs), as well as small amounts of radionuclides. Airborne radionuclides are considered the main source of any radiation dose that might be received by the public from plant operations.

A total of $7.9 \mathrm{Ci}$ of radionuclides was released to the air in $1993,99.1 \%$ of which was ${ }^{99} \mathrm{Tc}$, a weak beta emitter, and $0.8 \%$ of which was uranium isotopes, all alpha emitters. The remaining emissions consisted of the short-lived uranium daughters. The five-year trend for airborne radionuclide emissions is shown in Fig. 1.

Portsmouth ended production of highly enriched uranium (HEU) in 1992 and began decontaminating the associated process equipment to safely place it in long-term shutdown. The decontamination process converts technetium inside the process equipment to a gaseous form. Prior to initiating decontamination activities, it was not realized how much gaseous technetium would be generated in this manner. As a result, larger than expected amounts of ${ }^{99} \mathrm{Tc}$ were released to the atmosphere.

Historically, uranium has accounted for 75 to almost $90 \%$ of any public dose calculated from Portsmouth emissions. Consequently, the emission control systems are optimized to reduce uranium emissions first and technetium emissions second. Technetium emissions, which were well below normal before October 1992, increased from November 1992 until mid-1993.

Portsmouth initially attempted to reduce these emissions by increasing operation of the existing control systems. A committee was later assigned to identify more effective means of controlling technetium emissions. Once the committee's recommendations were implemented, technetium emissions were reduced to normal levels.

Smoke and $\mathrm{SO}_{2}$ from the coal-fired steam plant account for the largest amount of nonradiological air pollutants released from Portsmouth. In 1993, the X-600 steam plant achieved 100\% compliance for both opacity and $\mathrm{SO}_{2}$ permit limits.

\section{Waterborne Releases}

All nonradiological plant-site liquid effluents are regulated by the National Pollutant Discharge and Elimination System (NPDES). Treated effluents either discharge to surface streams that pass through the 
reservation to the Scioto River or are piped directly to the Scioto River. Radiological analyses are also performed at NPDES sampling locations.

A total of $0.72 \mathrm{Ci}$ of radionuclides was released to surface water in $1993,81 \%$ of which was ${ }^{99} \mathrm{Tc}$ and $17 \%$ of which was uranium isotopes. The remaining emissions consisted of the short-lived uranium daughters. This represents a decrease in uranium emissions and an increase in technetium emissions from 1992. In spite of this, 1993 releases of ${ }^{99} \mathrm{Tc}$ were still equal to the average annual releases of ${ }^{99} \mathrm{Tc}$ over the previous four years.

Uranium has a significantly higher dose response however, so the net effect on the public radiation dose is negligible. The five-year trend for waterborne radionuclide releases is shown in Fig. 2. Total radiological releases to surface waters were well below all applicable USEPA and DOE standards.

Nonradiological releases to surface waters are best summarized by the extent of compliance with the plant NPDES permit limits. Overall plant-wide NPDES compliance was $99.4 \%$ for CY 1993. Figure 3 shows the five-year trend for NPDES compliance.

\section{Chemical Releases}

Information relating to the storage and release of hazardous chemicals has been reported to the appropriate agencies. In compliance with the Superfund Amendments and Reauthorization Act (SARA), chemical releases are governed under SARA, Section 313. If a Section-313 chemical is manufactured, processed, or otherwise used in excess of a set amount, releases to the environment of that chemical must be reported to the USEPA and the OEPA. During 1993, approximately $158,000 \mathrm{~kg}(348,000 \mathrm{lb})$ of Section 313-listed chemicals were released to the environment, 99\% of which was CFC-114, the primary coolant used in the enrichment cascade.

In addition, Portsmouth voluntarily reports releases of large-inventory chemicals not listed under SARA, Section 313. During 1993, these releases consisted of $6,900 \mathrm{~kg}$ of hydrogen fluoride, $6,000 \mathrm{~kg}$ of other CFCs, $1,790 \mathrm{~kg}$ of 1,1,1-trichloroethane, and $540 \mathrm{~kg}$ of ethylene glycol.

\section{AMBIENT MONITORING}

Environmental monitoring systems at Portsmouth include ambient-sampling networks for direct monitoring of (gamma) radiation levels, air, surface water, groundwater, drinking water, creek and river sediments, soil, vegetation (cattle forage), food crops, and fish. Ambient monitoring results in 1993 indicated that Portsmouth operations were not having a significant environmental impact outside the reservation boundaries.

ORNL-DWG 94M-8262

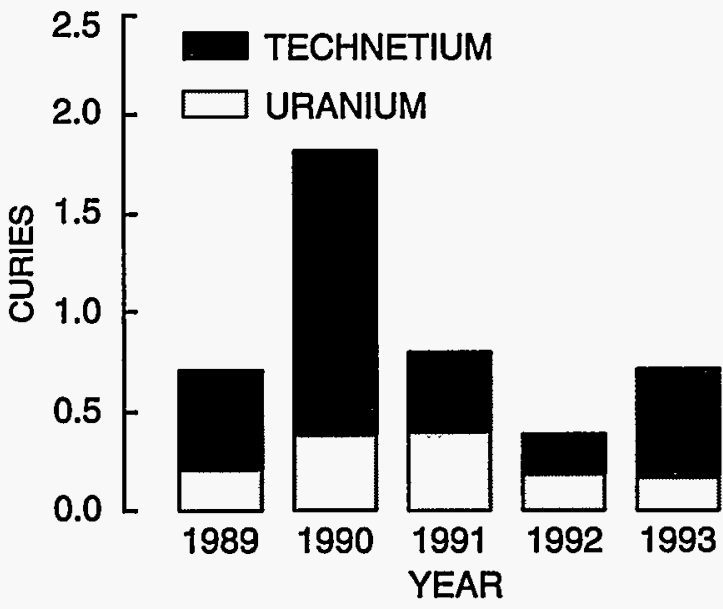

Fig. 2. Waterborne radionuclides discharged at Portsmouth, 1989-1993.

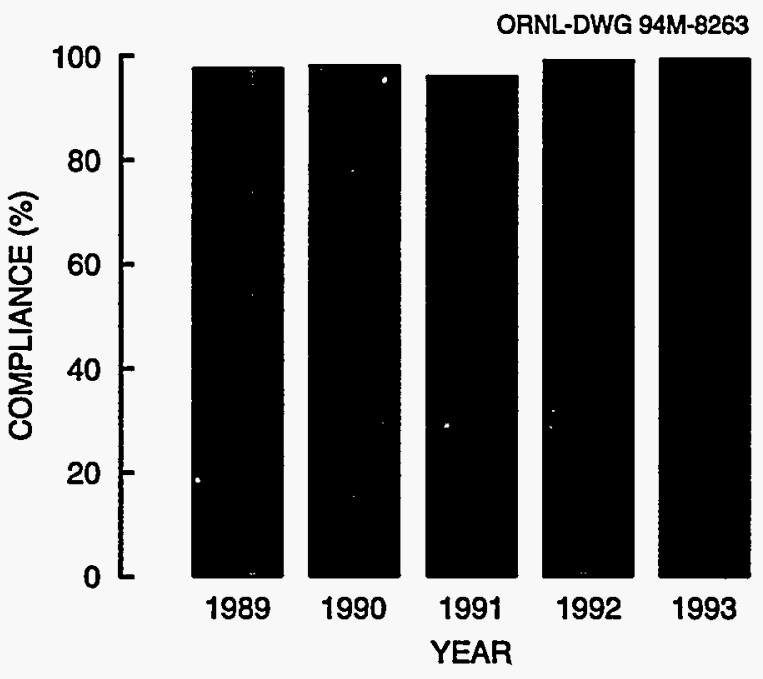

Fig. 3. NPDES compliance at Portsmouth, 1989-1993. 

plant:

Ambient-sampling networks are typically organized into three or four groups based on distance from the

- On-site stations in the Portsmouth area. This group includes locations near Perimeter Road, an area of limited public access, and locations within the plant's secured area, which is accessible only to employees and authorized visitors.

- Property-line stations on or near the DOE property line (the closest unrestricted public approach to the plant).

- Off-site stations at some distance from the Portsmouth site. These stations are located up to $16 \mathrm{~km}$ (10 miles) from the site and are sometimes divided into off-site and remote, or background, groups.

Individual (media-specific) networks include the following:

- 19 gamma radiation monitoring locations-9 on-site, 8 property line, and 2 off-site.

- 17 air sampling stations -6 on-site, 8 on or near the property line, and 3 off-site.

- 14 "off-site" (two of the downstream locations are within the DOE site and are only nominally off-site) surface water sampling locations- 6 downstream of the plant outfalls permitted under the NPDES, 4 upstream of plant outfalls, and 4 background samples about $16 \mathrm{~km}$ (10 miles) out in the four cardinal directions (north, east, south, west).

- 9 off-site drinking water sampling locations-homes of local residents with well, cistern, or natural spring water supplies who have allowed Portsmouth personnel to collect water samples for analysis.

- 17 stream sediment sampling locations-3 on-site, 10 off-site, and 4 background locations about $16 \mathrm{~km}$ (10 miles) out in the four cardinal directions.

- 46 soil sampling locations-15 internal, 9 on-site, 6 near off-site (within $5 \mathrm{~km}$ of the plant site), 12 remote ( 5 to $16 \mathrm{~km}$ from the plant site), and 4 background locations. (Property-line and off-site soil sampling locations are located with the vegetation sampling locations.)

- 31 vegetation sampling locations consisting of grass typical of local cattle forage $\rightarrow 9$ on-site, 6 near off-site, 12 remote, and 4 background.

- 33 samples of various local food crops.

- 12 fish samples from 7 locations-5 on-site, 1 off-site, and 1 background.

- 564 groundwater monitoring wells on-site. The majority of these wells were installed as part of the Groundwater Quality Assessment (GWQA), RFIs for quadrants I through IV, solid waste landfill compliance activities, underground storage tank investigations, or other site characterizations.

\section{External Gamma Radiation}

External gamma levels at and around Portsmouth are not significantly different from average radiation levels throughout Ohio (115 mrem/year). Gamma levels measured around Portsmouth averaged $118 \mathrm{mrem} / \mathrm{year}$ at the edge of the active plant area and $122 \mathrm{mrem} / \mathrm{year}$ around the reservation boundary. The higher gamma levels at more distant locations are from geological formations with higher concentrations of naturally occurring radioactive minerals that surround the Portsmouth reservation.

In 1993, the environmental external gamma monitoring system was combined with the health physics gamma monitoring system used for worker protection. The original environmental system was selected for maximum sensitivity at the expense of system reliability. Compensating for this reduced reliability produced gamma measurements that were not comparable with published external radiation data because they did not fully include contributions from natural cosmic radiation. The health physics system, although not as sensitive as the original environmental system, is still sensitive enough to make routine environmental measurements, does include cosmic radiation contributions, and is generally more reliable in operation. In addition, the health physics system is already accredited by the DOE Laboratory Accreditation Program and is expected to be accredited by the National Voluntary Laboratory Accreditation Program. 


\section{Ambient Air Monitoring}

Gross alpha and beta activities and gaseous fluoride concentrations in the air on and around the Portsmouth reservation during 1993 were all well within applicable standards and were not significantly affected by Portsmouth releases.

Annual average gross alpha activities at all monitoring locations accessible to the public (the USEPA definition of "ambient" includes public accessibility) were $0.005 \mathrm{pCi} / \mathrm{m}^{3}$ or less. The maximum alpha activity measured at any of these locations was only $0.014 \mathrm{pCi} / \mathrm{m}^{3}$. No standard exists for gross alpha activities in air, but an airborne uranium concentration equivalent to the USEPA dose standard of $10 \mathrm{mrem} /$ year would produce an annual gross alpha activity of $0.22 \mathrm{pCi} / \mathrm{m}^{3}$.

Annual average gross beta activities at all property-line and off-site monitoring locations were $0.051 \mathrm{pCi} / \mathrm{m}^{3}$ or less, with a maximum beta activity of $0.165 \mathrm{pCi} / \mathrm{m}^{3}$. On-site monitoring locations showed somewhat higher concentrations (up to $0.097 \mathrm{pCi} / \mathrm{m}^{3}$ annual average) to the east and northeast of the main plant area. No standard exists for gross beta activities in air, but an airborne ${ }^{99} \mathrm{Tc}$ concentration equivalent to the USEPA dose standard of $10 \mathrm{mrem} /$ year would produce an annual gross beta activity of $2 \mathrm{pCi} / \mathrm{m}^{3}$.

Weekly average gaseous fluoride concentrations at all monitoring locations accessible to the public averaged $0.15 \mu \mathrm{g} / \mathrm{m}^{3}$ or less, with a maximum weekly concentration of only $0.37 \mu \mathrm{g} / \mathrm{m}^{3}$. This concentration is well below the weekly standard for gaseous fluorides of $1.6 \mu \mathrm{g} / \mathrm{m}^{3}$ adopted by most states that have set ambient air standards for gaseous fluorides.

\section{Surface Water Monitoring}

Uranium and ${ }^{99} \mathrm{Tc}$ concentrations and gross alpha and beta activities in surface water on and around the Portsmouth reservation during 1993 were all well within applicable standards and posed no threat to human health or the environment.

The maximum uranium concentration in any surface water sample was only $7 \mathrm{ppb}$, with an annual average of only $3 \mathrm{ppb}$ (both measured in Little Beaver Creek), well below the 20-ppb standard the USEPA has proposed for drinking water. Uranium concentrations in Big Beaver Creek, Big Run Creek, and the Scioto River were slightly lower, with no significant difference between upstream and downstream sampling locations.

The maximum gross alpha activity in surface water samples was $30 \mathrm{pCi} / \mathrm{L}$, measured in both Little Beaver Creek and upstream in Big Beaver Creek. The maximum annual average gross alpha activity was $<9 \mathrm{pCi} / \mathrm{L}$. This is less than $2 \%$ of the DOE derived concentration guideline for ${ }^{234} \mathrm{U}$. No significant difference appeared between upstream and downstream gross alpha activities in any of the surface water bodies sampled, indicating no impact from plant discharges.

The maximum individual technetium concentration was $88 \mathrm{pCi} / \mathrm{L}$ with an annual average of $<27.5 \mathrm{pCi} / \mathrm{L}$ (Little Beaver Creek). This is less than $0.03 \%$ of the derived concentration guideline for technetium in surface water. Even the maximum individual concentration is less than $10 \%$ of the USEPA drinking water standard for beta emitters. Gross beta activities in surface water generally followed the technetium concentrations. No significant difference appeared between upstream and downstream technetium concentrations or gross beta activities in any of the surface water bodies sampled, indicating no impact from plant discharges.

\section{Soil and Sediment Sampling}

Stream sediments are sampled semiannually in parallel with surface water samples to measure whether waterborne releases are accumulating in local deposits. No radiological contamination was observed in sediments from Big Run Creek, the Scioto River, or the three outfalls themselves. In addition to radiological parameters, sediment samples taken during the fall of 1993 were analyzed for polychlorinated biphenyls (PCBs), mercury, and other RCRA parameters. No PCBs were found in any samples. As in past years, Portsmouth found minor uranium and technetium contamination in Little Beaver Creek sediments and minor technetium contamination in sediments from Big Beaver Creek. The contamination levels were not sufficient to warrant concern for human health and showed the same variability as noted in past years. These findings indicate that uranium and technetium are being deposited during low stream flows and then resuspended and removed during rainstorms. Trace concentrations of mercury were detected in a few samples, including one from the Scioto River upstream 
of Portsmouth discharges. None of the other parameters indicated a significant impact on the environment from Portsmouth discharges.

Soil samples are collected semiannually and are analyzed for radiological parameters. In 1993, samples were also analyzed for chromium to verify that historical air emissions have not accumulated. Soil samples showed no significant contamination of the environment around the plant site. Analytical results for all external soil sample locations indicated that radiological parameters were within normal levels and that chromium concentrations were consistent with the 10-mile background samples. All internal soil sample locations were found to be uncontaminated except for one location that was already known to be radiologically contaminated and two locations adjacent to the plant cooling towers that showed minor chromium accumulation.

\section{Biological Monitoring}

Biological monitoring conducted on and around Portsmouth during 1993 included semiannual vegetation (grass) samples collected with the semiannual soil samples, annual samples of locally grown food crops, and annual samples of fish from local streams. Vegetation samples were analyzed for uranium, technetium, and fluoride concentrations. Food crops were analyzed for uranium and gross alpha activity. Fish tissues were analyzed for uranium, technetium, chromium, PCB concentrations, and gross alpha and gross beta activity.

Analysis from semiannual vegetation samples revealed no significant environmental contamination. No uranium was detected in any of the vegetation samples, and all fluoride concentrations were within normal ranges. Very low levels of technetium $(<1 \mathrm{pCi} / \mathrm{g})$ were detected in some vegetation samples but not in a pattern consistent with airborne deposition. During the spring sampling event (when higher than normal levels of technetium were being released), technetium was detected in vegetation samples from along the east reservation boundary. During the fall sampling event (when technetium releases had decreased), technetium was detected in vegetation samples taken from between 5 to $10 \mathrm{~km}$ west of the plant. Furthermore, analysis of vegetation samples taken from between the plant and the positive samples did not reveal any detectable technetium. Based on these results, Portsmouth believes the technetium analyses do not represent actual technetium contamination.

Analysis of the crop samples revealed no detectable uranium or gross alpha activity.

Fish sample analyses revealed no detectable levels of uranium, technetium, chromium, or gross alpha or beta activity. PCB concentrations in fish samples taken on-site ranged from undetectable $(<0.2 \mathrm{ppm})$ to $3.2 \mathrm{ppm}$. The Food and Drug Administration standard for PCBs in food is $2 \mathrm{ppm}$.

\section{RADIATION DOSE TO THE PUBLIC}

The maximum potential 50-year committed effective dose equivalent (EDE) to any individual from Portsmouth activities during 1993 would be $0.91 \mathrm{mrem} / \mathrm{year}$, much lower than the applicable USEPA standard of $10 \mathrm{mrem} / \mathrm{year}$ or the DOE standard of $100 \mathrm{mrem} / \mathrm{year}$. A comparison of maximum potential EDEs resulting from airborne emissions over the last five years is shown in Fig. 4. The calculated population dose (collective EDE) from airborne radionuclides was 0.38 person-rem/year to the nearest community and 11.6 person-rem/year to the total population within $80 \mathrm{~km}$ ( 50 miles) of the plant. None of the potential doses calculated resulting from Portsmouth operations is significant to public health.

The calculated EDE for those drinking water and eating fish from the Scioto River throughout 1993 was only $0.007 \mathrm{mrem} / \mathrm{year}$. This dose is well below the USEPA national standard of $4 \mathrm{mrem} / \mathrm{year}$ for radionuclides in drinking water as well as the DOE limit of $100 \mathrm{mrem} /$ year for all exposure pathways. This calculated dose is hypothetical and should be considered very conservative. No public water supply or known private water supply is drawn from the Scioto River. Sport fishing is the only known activity taking place on the river downstream of Portsmouth. This hypothetical maximum waterborne dose is also calculated at a location on the opposite side of the plant (southwest) from the hypothetical maximum airborne dose (east-northeast), making it unlikely that one individual could be exposed to both doses. A comparison of maximum potential EDEs resulting from waterborne emissions over five years is shown in Fig. 5. Waterborne population doses are not calculated because the best estimate of the exposed population is zero. 


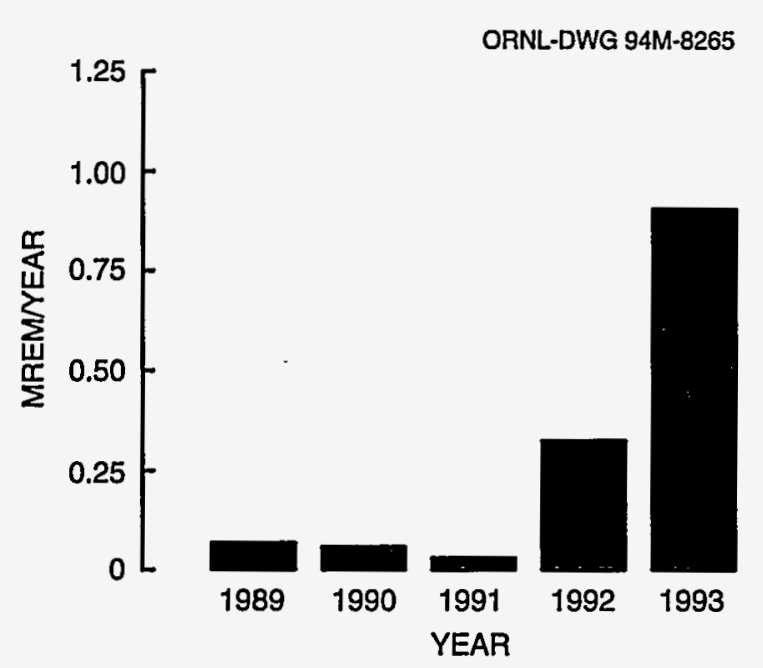

Fig. 4. Maximum predicted individual EDEs from airborne radionuclides, 1989-1993.

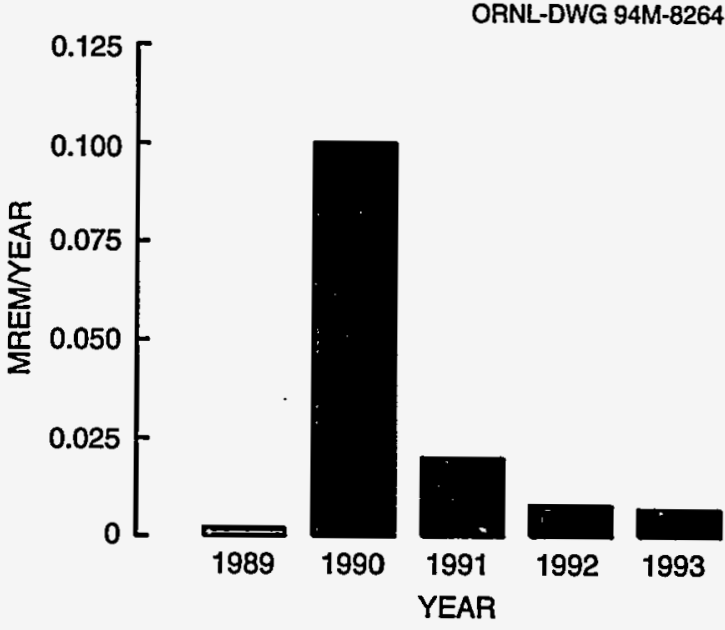

Fig. 5. Maximum predicted individual EDEs from waterborne radionuclides, 1989-1993.

\section{GROUNDWATER MONITORING}

The Groundwater Monitoring Program includes assessment monitoring and surface water monitoring associated with four RCRA land disposal units, detection monitoring associated with the sanitary landfill, and off-site monitoring of residential water sources (i.e., cisterns, springs, and wells).

The RCRA assessment monitoring program is based on results of a groundwater quality assessment completed by Geraghty \& Miller, Inc., in 1989 (Groundwater Quality Assessment of Four RCRA Units). Quarterly monitoring for a list of approved analytes is accomplished by sampling wells installed in the Gallia sand and the Berea sandstone. Sampling locations include 26 wells at the X-701B surface impoundment, 26 wells at the X-749 landfill, 15 wells at the X-231B land treatment area, and 15 wells at the X-616 chromium sludge surface impoundments. In addition, points of groundwater discharge to surface water associated with these units are monitored at Little Beaver Creek, Big Run Creek, the southwest drainage ditch, the west drainage ditch, and the north holding pond.

Detection monitoring at the X-735 sanitary landfill is accomplished by sampling six groundwater monitoring wells on the perimeter of the landfill. These wells were installed according to RCRA protocol to comply with changes in solid waste regulations.

In accordance with the requirements and schedules specified in the consent decree issued by the Ohio Attorney General's Office on August 29, 1989, and with the RCRA, Section 3008(h), consent order issued by USEPA Region V on September 29, 1989, the RFI for quadrants I and II were completed. Two new contaminated groundwater plumes were identified. These include one plume located near the X-700 chemical cleaning facility and the X-705 decontamination buildings and a second plume located near the X-710 laboratory.

\section{OTHER ENVIRONMENTAL PROGRAMS AND ISSUES}

\section{Underground Storage Tanks (USTs)}

Eighteen USTs were tightness tested in 1993, and all but one were certified as tight. The exception was a small (550-gal) diesel tank connected to an emergency generator. Although a site assessment indicated no fuel contamination in the surrounding soils or groundwater, a remedial action plan was submitted to the state at the state's request. One other tank had also been suspected of leaking based on inventory records but passed the tightness testing. 
In addition, six other USTs have been scheduled for closure and removal. Three of these USTs have been emptied and will be closed under state UST regulations because they are no longer needed. The other three USTs, which were leased to the Ohio Army National Guard, are located within a trichloroethylene-contaminated groundwater plume and are being characterized for closure under RCRA during the Quadrant I RFI.

\section{Unusual Occurrences}

During 1993, Portsmouth had three spills that required reporting to the National Response Center. All three were small spills (maximum of $15 \mathrm{gal}$ ) of ethylene glycol (antifreeze) that were reportable only because ethylene glycol was still subject to the statutory default reportable quantity of $1 \mathrm{lb}$ at the time of the spills. The USEPA has since proposed a specific reportable quantity of $5,000 \mathrm{lb}$ for ethylene glycol.

Contaminated groundwater captured by the X-201B interceptor trench is pumped to the X-624 treatment facility. Two pumps are used. One of the pumps failed in late 1992, and it was believed that the remaining pump could adequately pump all of the groundwater captured by the interceptor trench. Subsequent evaluation indicated that this was incorrect, and a new pump was installed. In accordance with guidance from the OEPA, the event was classified as an unauthorized discharge under the NPDES program, and a five-day follow-up letter was sent to the OEPA describing the incident and its resolution.

\section{Special Studies}

In the summer and fall of 1993, DOE initiated the preparation of a baseline ecological risk assessment for Portsmouth including a wetlands survey, a threatened and endangered plant survey, a threatened and endangered animal survey, and a bat survey. To date, Portsmouth has completed the threatened and endangered animal survey and the wetlands survey. The threatened and endangered plant survey began April 4, 1994, and was completed in October 1994. The bat survey was completed in September 1994. The final reports will be submitted to DOE; the OEPA; the U.S. Fish and Wildlife Service; the Department of Natural Resources, Division of Wildlife and Division of Natural Areas and Preserves; and the Ohio Biological Survey.

\section{REFERENCE}

Geraghty and Miller. 1989. Groundwater Quality Assessment of Four RCRA Units. Dublin, Ohio. 


\section{Acronyms and Abbreviations}

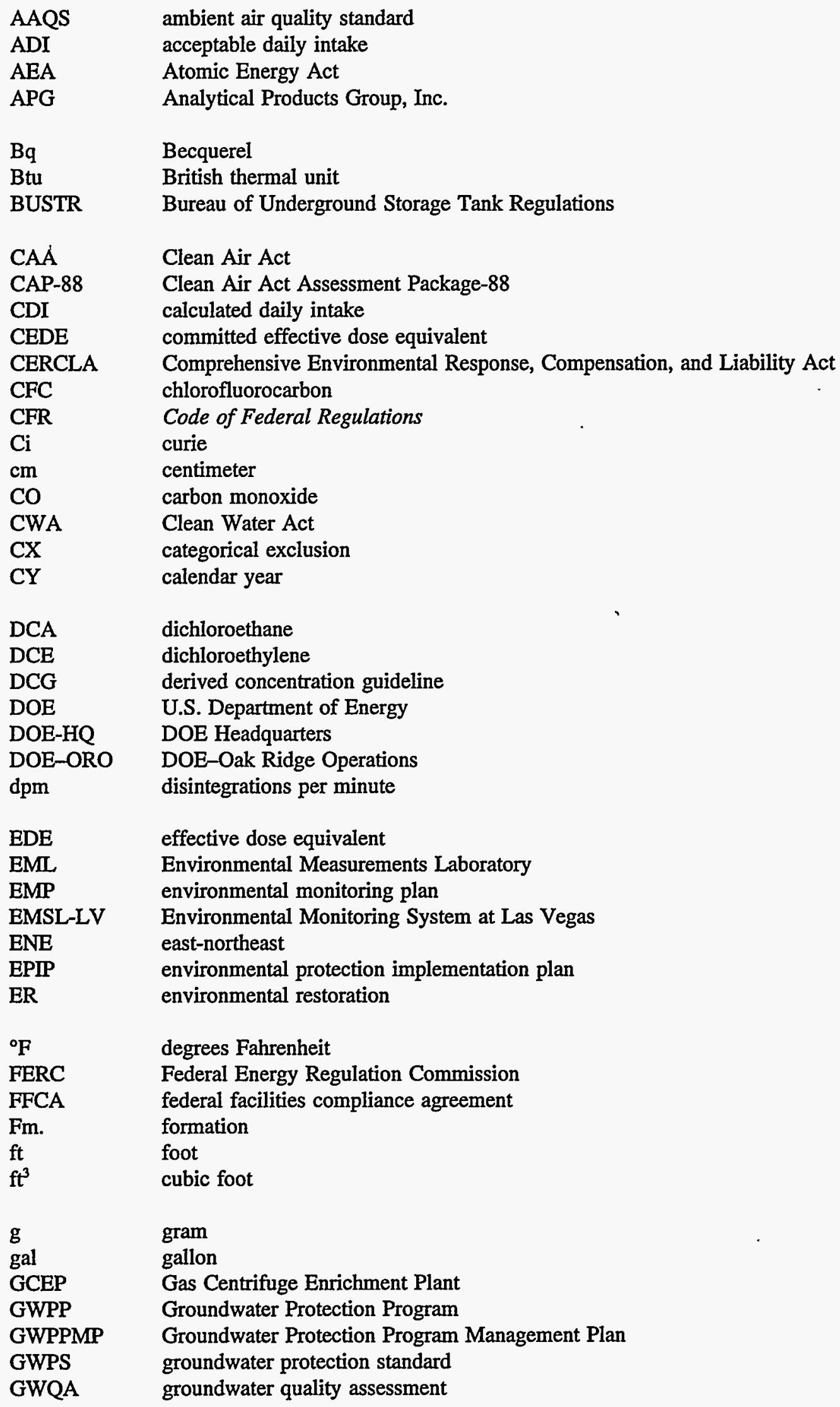




\begin{tabular}{|c|c|}
\hline ha & hectare \\
\hline HASA & high-assay sampling area \\
\hline HF & hydrogen fluoride \\
\hline $\mathrm{HOCl}$ & hypochlorite \\
\hline HSWA & Hazardous and Solid Waste Amendment \\
\hline in. & inch \\
\hline INEL & Idaho National Engineering Laboratory \\
\hline IRM & interim remedial measure \\
\hline $\mathrm{kg}$ & kilogram \\
\hline $\mathrm{km}$ & kilometer \\
\hline $\mathrm{km}^{2}$ & square kilometer \\
\hline $\mathrm{L}$ & liter \\
\hline $\mathrm{lb}$ & pound \\
\hline LDR & land disposal restriction \\
\hline LLW & low-level waste \\
\hline $\mathrm{m}$ & meter \\
\hline $\mathrm{m}^{2}$ & square meter \\
\hline $\mathrm{m}^{3}$ & cubic meter \\
\hline $\mathrm{mg}$ & milligram \\
\hline Mgd & million gallons per day \\
\hline$\mu \mathrm{Ci}$ & microcurie \\
\hline$\mu \mathrm{g}$ & microgram \\
\hline$\mu \mathrm{m}$ & micron \\
\hline$\mu \mathrm{rad}$ & microrad \\
\hline mile $^{2}$ & square mile \\
\hline $\mathrm{mL}$ & milliliter \\
\hline $\mathrm{mm}$ & millimeter \\
\hline MMES & Martin Marietta Energy Systems, Inc. \\
\hline $\begin{array}{l}\text { MMUS } \\
\text { mrem }\end{array}$ & $\begin{array}{l}\text { Martin Marietta Utility Services, Inc. } \\
\text { millirem }\end{array}$ \\
\hline NEPA & National Environmental Policy Act of 1990 \\
\hline $\begin{array}{l}\text { NESHAP } \\
\text { ng }\end{array}$ & $\begin{array}{l}\text { National Emission Standards for Hazardous Air Pollutants } \\
\text { nanogram }\end{array}$ \\
\hline NGVD & national geodetic vertical datum of 1929 \\
\hline NIOSH & National Institute for Occupational Safety and Health \\
\hline NIST & National Institute for Standards and Technology \\
\hline $\mathrm{NO}_{\mathrm{x}}$ & nitrogen oxides \\
\hline NOAA & National Oceanographic and Atmospheric Administration \\
\hline NOV & notice of violation \\
\hline NPDES & National Pollutant Discharge Elimination System \\
\hline NRC & Nuclear Regulatory Commission \\
\hline NVLAP & National Voluntary Laboratory Accreditation Program \\
\hline $\mathrm{OAC}$ & Ohio Administrative Code \\
\hline OANG & Ohio Army National Guard \\
\hline OEPA & Ohio Environmental Protection Agency \\
\hline PCB & polychlorinated biphenyl \\
\hline $\mathrm{pCi}$ & picrocurie \\
\hline $\mathrm{PM}_{10}$ & particulate matter less than 10 microns in diameter \\
\hline
\end{tabular}




\begin{tabular}{|c|c|}
\hline $\begin{array}{l}\text { ppb } \\
\text { ppm }\end{array}$ & $\begin{array}{l}\text { part per billion } \\
\text { part per million }\end{array}$ \\
\hline $\begin{array}{l}\mathrm{QA} \\
\mathrm{QC}\end{array}$ & $\begin{array}{l}\text { quality assurance } \\
\text { quality control }\end{array}$ \\
\hline $\begin{array}{l}\text { RCRA } \\
\text { RCW } \\
\text { RFI } \\
\text { RW }\end{array}$ & $\begin{array}{l}\text { Resource Conservation and Recovery Act } \\
\text { recirculating cooling water } \\
\text { RCRA facility investigation } \\
\text { routine water }\end{array}$ \\
\hline $\begin{array}{l}\text { SARA } \\
\mathrm{SO}_{2} \\
\mathrm{SU} \\
\mathrm{SWMU}\end{array}$ & $\begin{array}{l}\text { Superfund Amendments and Reauthorization Act } \\
\text { sulfur dioxide } \\
\text { standard unit } \\
\text { solid waste management unit }\end{array}$ \\
\hline $\begin{array}{l}\text { Tc } \\
\text { TCA } \\
\text { TCE } \\
\text { TCL/TAL } \\
\text { TLD } \\
\text { TSCA }\end{array}$ & $\begin{array}{l}\text { technetium } \\
\text { trichloroethane } \\
\text { trichloroethylene } \\
\text { target compound list/target analyte list } \\
\text { thermoluminescent dosimeter } \\
\text { Toxic Substances Control Act }\end{array}$ \\
\hline $\begin{array}{l}\text { U } \\
\text { UF } \\
\text { USEC } \\
\text { USEPA } \\
\text { UST }\end{array}$ & $\begin{array}{l}\text { uranium } \\
\text { uranium hexafluoride } \\
\text { United States Enrichment Corporation } \\
\text { U.S. Environmental Protection Agency } \\
\text { underground storage tank }\end{array}$ \\
\hline VOC & volatile organic compound \\
\hline $\begin{array}{l}\text { WP } \\
\text { WS }\end{array}$ & $\begin{array}{l}\text { water pollution performance evaluation } \\
\text { water supply }\end{array}$ \\
\hline
\end{tabular}




\title{
1. Site and Operations Overview
}

\begin{abstract}
The purpose of this document is to summarize the status of compliance with environmental laws, regulations, and orders; effluent monitoring data; and environmental surveillance results at the Portsmouth Gaseous Diffusion Plant (Portsmouth). The U.S. Department of Energy (DOE) owns the Portsmouth facility and requires that environmental monitoring be conducted and documented for all of its facilities under the purview of DOE Order 5400.1. The main process at Portsmouth is the separation of uranium isotopes through gaseous diffusion.
\end{abstract}

\section{BACKGROUND}

This document contains a summary of environmental monitoring activities at the Portsmouth Gaseous Diffusion Plant (Portsmouth). Environmental monitoring at Portsmouth consists of two major activities: effluent monitoring and environmental surveillance. Effluent monitoring is direct measurement or the collection and analysis of samples of liquid and gaseous discharges to the environment. Environmental surveillance is direct measurement or the collection and analysis of samples of air, water, soil, foodstuff, biota, and other media.

Environmental monitoring is performed to characterize and quantify contaminants, assess radiation exposures of members of the public, demonstrate compliance with applicable standards and permit requirements, and detect and assess the effects (if any) on the local environment. Multiple samples are collected throughout the year and are analyzed for radioactivity, chemical content, and various physical attributes.

\section{DESCRIPTION OF SITE LOCALE}

Portsmouth is located in sparsely populated, rural Pike County, Ohio, on a $16.2-\mathrm{km}^{2}\left(6.3-\mathrm{mile}^{2}\right)$ site (see Fig. 1.1). The site is $1.6 \mathrm{~km}$ ( 1 mile) east of the Scioto River valley in a small valley running parallel to and approximately $37 \mathrm{~m}(120 \mathrm{ft})$ above the Scioto

River floodplain. Figure 1.2 depicts the plant site and its immediate environs.

Pike County has approximately 24,250 residents. Scattered rural development is typical; however, the county contains numerous small villages, such as Piketon, Wakefield, and Jasper, that lie within a few kilometers of the plant. The county's largest community, Waverly, is about $19 \mathrm{~km}$ (12 miles) north of the plant site and has a population of about 4500 residents. The nearest residential center in this area is Piketon, which is about $8 \mathrm{~km}$ ( 5 miles) north of the plant on U.S. Route 23; its population is about 1700 . Several residences are adjacent to the southern half of the eastern boundary and along Wakefield Mound Road (old U.S. 23), directly west of the plant. Two nursing homes with a combined capacity of 60 persons are located along Wakefield Mound Road.

Additional population centers within $80 \mathrm{~km}$ (50 miles) of the plant are Portsmouth (population 22,249), $43 \mathrm{~km}$ (27 miles) south; Chillicothe (population 21,923), $43 \mathrm{~km}$ (27 miles) north; and Jackson (population 6144),

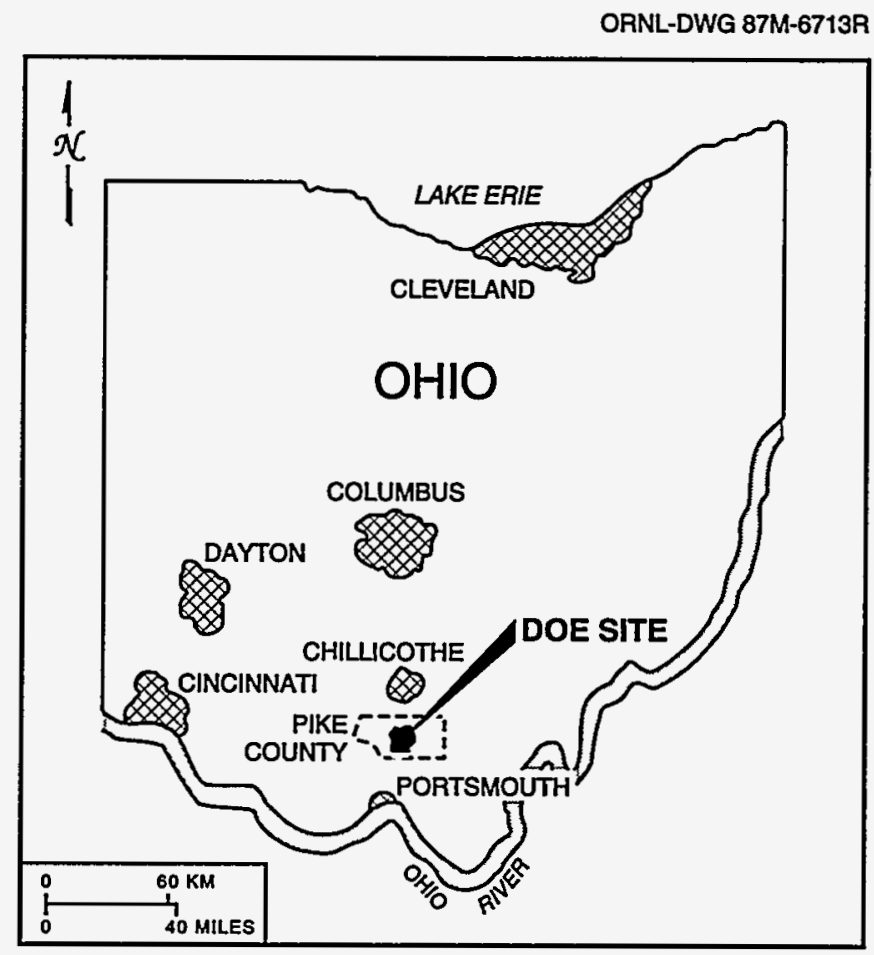

Fig. 1.1. Location of the Portsmouth site within the state of Ohio. 
$29 \mathrm{~km}$ (18 miles) east. The total population of the area lying within an $80-\mathrm{km}$ (50-mile) radius of the plant is approximately 900,000 (U.S. Department of Commerce 1991).

\section{DESCRIPTION OF SITE OPERATIONS AND FACILITIES}

The principal site process is the separation of uranium isotopes through gaseous diffusion. The gaseous diffusion process for uranium enrichment is based on the fact that lighter molecules diffuse slightly faster than heavier molecules through the walls of a porous tube called a barrier. Gaseous uranium hexafluoride is partially diffused through the barrier. The portion of gas passing through the barrier wall is slightly richer in ${ }^{235} \mathrm{U}$. Support operations include the feed and withdrawal of material from the primary process, treatment of water for both potable and cooling purposes, steam generation for heating purposes, decontamination of equipment removed from the plant for maintenance or replacement, recovery of uranium from various waste materials, and treatment of industrial wastes.

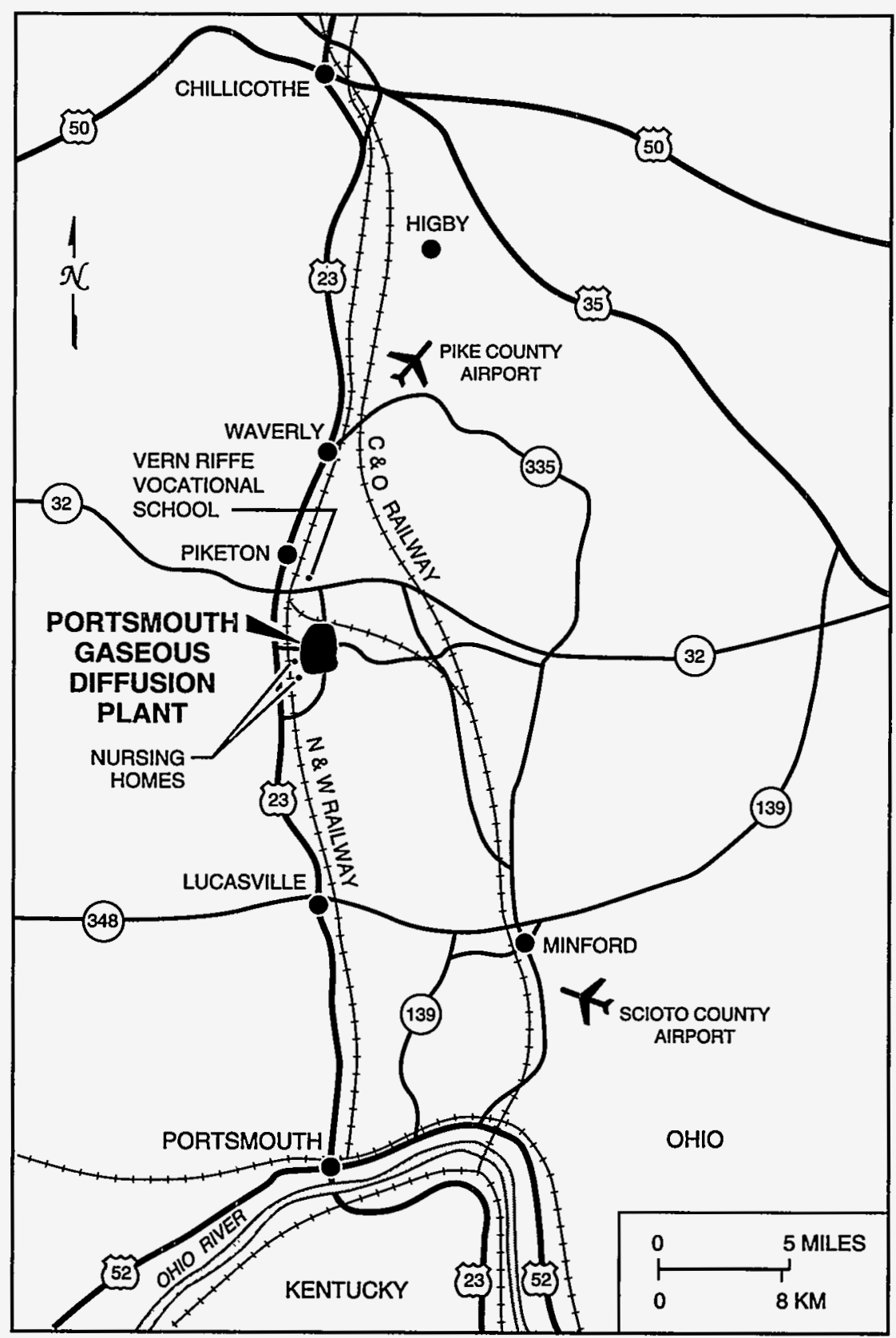

Fig. 1.2. Location of the Portsmouth site in relation to the geographic region. 


\title{
2. Environmental Compliance
}

\author{
Abstract \\ Ongoing self-assessments are conducted at Portsmouth Gaseous Diffusion Plant to identify \\ environmental issues. These issues are discussed openly with regulatory agencies to ensure \\ compliance with applicable regulations.
}

\section{BACKGROUND AND OVERVIEW}

The Portsmouth Gaseous Diffusion Plant (Portsmouth) is required to operate in conformance with environmental requirements established by a number of federal and state statutes and regulations, executive orders, U.S. Department of Energy (DOE) orders, and compliance and settlement agreements. Compliance status with regard to these various authorities is summarized as follows.

Several federal, state, and local agencies are responsible for enforcing environmental regulations at Portsmouth. As of July 1, 1993, responsibility for implementing environmental compliance was split between DOE, as site owner and operator of waste management and environmental remediation projects, and the United States Enrichment Corporation (USEC), a government-owned corporation formed by the National Energy Policy Act (NEPA) of 1992 to take over the nation's uranium enrichment business. The management contractor for DOE is Martin Marietta Energy Systems, Inc. (MMES), and a new subsidiary, Martin Marietta Utility Services, Inc., was formed to provide management services for USEC.

Under the terms of the lease, USEC has assumed responsibility for compliance activities directly associated with uranium enrichment operations such as air emission permits for cascade vents and maintenance facilities, National Pollutant Discharge Elimination System (NPDES) compliance for the X-6619 sewage treatment plant and other leased facilities, and management of solid wastes generated by enrichment operations (with the exception of the "legacy" wastes mentioned subsequently). DOE retains responsibility for the site Environmental Restoration Program; the bulk of the Waste Management Program, including waste inventories that predate July 1, 1993, wastes generated by current DOE activities, and wastes containing legacy constituents, such as asbestos, polychlorinated biphenyls (PCBs), and transuranics; and NPDES compliance at outfalls not leased to USEC and air emission sources not leased to USEC.

The Nuclear Regulatory Commission (NRC) is scheduled to assume direct oversight of USEC operations in October 1995. In the interim, DOE is providing oversight of NRC-regulated activities.

Principal among other regulating agencies are the U.S. Environmental Protection Agency (USEPA) (both at Headquarters and Region V), the Ohio Environmental Protection Agency (OEPA), and the Ohio State Fire Marshal's Office. These agencies issue permits, review compliance reports, participate in joint monitoring programs, inspect facilities and operations, and oversee compliance with applicable regulations.

Although much progress has been made toward achieving full regulatory compliance at Portsmouth, much remains to be accomplished. Ongoing self-assessments of compliance status continue to identify environmental issues. These issues are discussed openly with the regulatory agencies to ensure that compliance with all environmental regulations will be attained.

\section{COMPLIANCE STATUS}

\section{Resource Conservation and Recovery Act (RCRA)}

As of the end of 1993, negotiations for a RCRA Part B permit for Portsmouth were continuing between DOE and the state of Ohio. Portsmouth operates two RCRA container storage units (X-7725 and X-326L) under the OEPA Director's Findings and Orders. In addition, several 90-day storage areas have been established for temporary storage of hazardous wastes.

Certification of closure has been received from the OEPA for three RCRA facilities. Four additional units have been closed and are awaiting OEPA certification. Closure plan approval for nine units was received from the OEPA in 1992, and the units were being closed as of the end of 1993. In July 1992, closure plans for the $\mathrm{X}-701 \mathrm{C}$ neutralization pit and the X-230J7 surface impoundment were submitted to the OEPA. Per OEPA 
request, closure plans for these two units have been revised and were resubmitted in late 1993 for OEPA review and approval. As of December 31,1993, the OEPA had not taken any action. A closure plan was submitted to the OEPA for the X-344A neutralization pit in 1993. Table 2.1 shows the current RCRA closure status.

Table 2.1. RCRA closure status at Portsmouth for 1993

\begin{tabular}{ll}
\hline \multicolumn{1}{c}{ Status } & \multicolumn{1}{c}{ Facility } \\
\hline Certification of closure received from the OEPA & X-616 surface impoundments \\
& X-705A incinerator \\
& X-749 landfill (northern portion) \\
Closed and awaiting certification & X-700 tank 7 \\
& X-750 tank \\
& X-752 container storage unit \\
Closure plans approved and closure under way & X-749 landfill (southern portion) \\
& X-231B land treatment area \\
& X-700 tank 6 \\
X-700 tank 8 \\
X-735 landfill (cells 1-6) \\
X-740 tank \\
X-740 container storage unit \\
X-744G(R) container storage unit \\
X-744G(U) container storage unit \\
X-744Y container storage yard \\
Revised closure plans submitted to the OEPA for review \\
X-749A classified materials landfill \\
X-701C neutralization pit \\
X-230J-7 surface impoundment \\
X-344A neutralization pit \\
\hline
\end{tabular}

\section{Consent Decree/Consent Order}

A consent decree with the state of Ohio and a consent order with the USEPA require the investigation and cleanup of releases to surface water and air; spills from past operations, including the elimination of groundwater contamination plumes; and solid waste management units, of which 74 have been identified. These 74 units are distributed over four areas (or quadrants) that are defined based on groundwater movement patterns. RCRA facility investigations (RFIs) for quadrants I and II have been completed, and reports have been submitted to the USEPA and the OEPA. RFI field work for Quadrant III is under way, and the RFI work plan for Quadrant IV has been submitted and approved by the OEPA and USEPA.

In addition, a work plan for a separate RFI for potential air emissions from solid waste management units was revised as per USEPA comments. Ambient air sampling began on October 18, 1993, and will continue into August 1994. The regulatory milestone is submittal of the Air RFI report to the USEPA and OEPA on February 28, 1995.

\section{Notices of Violation (NOVs)}

In 1993, two NOVs were issued by the OEPA, and an additional NOV was issued by USEPA Region V. These NOVs are summarized as follows.

\section{2-2 Environmental Compliance}


The OEPA cited Portsmouth for five violations identified in the annual RCRA compliance audit. These noncompliances were: (1) three drums not marked with accumulation start dates, (2) management of satellite accumulation areas, (3) testing of fire extinguishers and maintenance of testing logs, (4) hazardous waste in dented and rusty containers, and (5) an unlabeled drum. In addition, this NOV reiterated five outstanding violations from previous audits. These violations were: (1) failure to make hazardous waste determinations regarding depleted uranium hexafluoride cylinders and lithium hydroxide; (2) storage of hazardous waste in $\mathrm{X}-700$ tank 7 for more than 90 days; (3) failure to conduct tank assessments on X-700 tanks 6,7 , and 8 and the $\mathrm{X}-740$ and X-750 tanks; (4) lack of secondary containment for the five tanks listed in item 3; and (5) lack of a hazardous waste permit for X-700 tank 7 .

The five new violations identified in the annual RCRA inspection have been corrected. Efforts are under way to negotiate an amended consent decree with the OEPA to address the five outstanding items. The X-700 tank 7 and X-750 tank have been closed.

The other NOV was received from the OEPA for failure to notify and gain approval from the OEPA to refrain from installing a backup pump in each sump of the X-701B trench intercept system as shown in the approved work plan, failure to conduct all of the groundwater monitoring tasks as outlined in the approved work plan for X-701B, and failure to operate and maintain the X-701B trench intercept system and X-231B as per their approved work plans.

Portsmouth conducted a transit time modeling study to determine how long it would take for trichloroethylene-contaminated groundwater to be released to the environment if any pump were down and provided a copy of the study to the OEPA. In addition, backup pumps are available in stores if needed and can be installed within 8 hours.

The NOV received from the USEPA disapproved the revised Air RFI Work Plan and the Quality Assurance Project Plan. The NOV stated that the USEPA determined that the requirements of the consent order had not been met because of failure to revise the documents in accordance with the USEPA's comments. The deficiencies identified by the USEPA have since been resolved, and the Air RFI is in progress.

\section{Federal Facilities Compliance Act}

The Federal Facilities Compliance Act was enacted by Congress in October 1992. Federal facilities are now required to develop and submit site treatment plans for treatment of mixed wastes. Approval authority has been delegated to the OEPA.

A conceptual site treatment plan was submitted in October 1993. A draft site treatment plan is scheduled to be submitted in August 1994. The final site treatment plan must be developed and submitted by February 1995.

\section{Comprehensive Environmental Response, Compensation, and Liability Act (CERCLA)}

Other than the requirements relating to releases reportable to the National Response Center (which are discussed in Section 9, "Unusual Occurrences and Special Studies"), CERCLA requirements do not apply to Portsmouth. Portsmouth is not on the National Priorities List, and the USEPA and the OEPA have chosen to oversee environmental remediation activities at Portsmouth under the provisions of RCRA.

\section{Superfund Amendments and Reauthorization Act (SARA), Title III}

A total of 35 hazardous chemicals were reported under SARA, Section 312, as being stored on-site in amounts above regulatory thresholds during 1993. An updated list of eight extremely hazardous substances that were stored on-site was submitted to the State Emergency Response Center and the Local Emergency Planning committees in accordance with SARA, Section 302. The eight extremely hazardous substances were ammonia, chlorine, cyclohexylamine, fluorine, hydrogen fluoride, nitric acid, sulfur dioxide, and sulfuric acid.

In 1993, approximately $158,000 \mathrm{~kg}$ of toxic chemicals listed in SARA, Section 313 , were released to the environment. Freon-114 accounted for approximately $156,000 \mathrm{~kg}(99 \%)$ of the chemical releases at Portsmouth 
in 1993 (see chemical release data in Appendix C of this report). Only $1700 \mathrm{~kg}$ of chemicals other than Freon-114 were released in 1993.

Pursuant to Section 304, three releases of ethylene glycol were reported in 1993 in amounts of 15 gal, 10 gal, and 0.25 gal.

\section{Underground Storage Tanks (USTs)}

The UST program is managed in accordance with the regulations of DOE, USEPA, OEPA, and the Ohio State Fire Marshal's Bureau of Underground Storage Tank Regulations (BUSTR). Portsmouth registered 26 tanks with BUSTR in 1993, including one waste oil tank at the X-750 facility that was closed under RCRA on May 20, 1993. Tanks previously leased to the Defense Logistics Agency and tanks currently leased to the Ohio Army National Guard (OANG) were included on the Portsmouth annual tank registration.

There are 26 USTs at the Portsmouth facility. After July 1, 1993, MMES retained responsibility for 14 USTs, including tanks at the X-1107DV and X-7721 facilities previously leased by the Defense Logistics Agency and tanks at the X-751 facility currently leased by the OANG. MMUS became responsible for maintaining 11 USTs, and 1 tank was removed under RCRA [Title 40, Code of Federal Regulations, Part 264 (40 CFR 264)].

Of the 26 USTs, 22 are regulated according to 40 CFR 280. Four USTs are not regulated because two of them previously leased to the Defense Logistics Agency were never put into service, one tank was closed under the requirements of 40 CFR 264, and one tank registered at the facility leased by the OANG has not been located. This OANG-leased facility will be investigated to determine the location or existence of this tank.

All 22 regulated tanks are in compliance with current regulatory requirements prescribed in 40 CFR 280 . However, only 2 of the 22 regulated tanks meet new technical requirements that will become applicable December 22, 1998. Of the remaining 20 tanks, 3 have been pumped and are scheduled for closure by August 30,1994. Another tank is undergoing BUSTR corrective actions in accordance with Ohio Administrative Code (OAC) 1301:7-9-13 because of a failed tightness test. One tank was suspected of leaking but passed a tightness test; this tank has been pumped and must either be put back into service or have closure proceedings initiated by July 8, 1994.

A site feature scoring system report regarding several previously removed USTs was submitted to BUSTR. At the request of BUSTR, a second site assessment was performed at the site of three previously closed USTs (X-750). The initial findings indicated no need for further remediation. The soils from this removal have been treated with microbial agents and disposed of in accordance with the OEPA Petroleum Contaminated Soils Policy, which was superseded in September 1993 by the BUSTR Stockpile Guidance Document.

\section{Toxic Substances Control Act (TSCA)}

The electrical power system at Portsmouth uses PCB transformers and large, high-voltage PCB capacitors to supply electricity to the enrichment cascade. At the end of CY 1993, the plant-site inventory of PCBs in electrical equipment (including spare equipment) was approximately 900,000 kg.

Non-totally enclosed PCBs are in service at Portsmouth in duct gaskets and some large lube oil systems. These two issues are addressed in a federal facilities.compliance agreement (FFCA) between DOE and the USEPA. The agreement requires that troughs be installed under all motor exhaust duct gaskets to collect leaks of PCB oils. March 30, 1994, is the scheduled date for certification of the troughing. The agreement also requires all PCB-contaminated lube oil systems to be drained. The PCB-contaminated systems were drained and retrofilled by the end of March 1993. All the lube systems were successfully reclassified as either detectable PCB or non-PCB by the end of June 1993 and were returned to service.

Portsmouth operates several storage areas for PCB wastes. The main storage areas meet all applicable requirements of $40 \mathrm{CFR} 761.65$. Some storage areas for uranium-contaminated PCB waste meet modified requirements regarding curb height and specific containers to allow for nuclear criticality safety requirements. Virtually all of Portsmouth's PCB wastes are in long-term storage because of the lack of disposal facilities authorized to dispose of wastes containing both PCBs and radionuclides.

Other sections of TSCA have little or no impact on Portsmouth. Although friable asbestos is regulated under TSCA, the specific regulations applicable to Portsmouth are duplications of other state and federal regulations,

\section{2-4 Environmental Compliance}


that is, National Emission Standards for Hazardous Air Pollutants (NESHAP) and Occupational Safety and Health Administration regulations. Portsmouth also responds to USEPA requests for health and safety data as required, but because Portsmouth neither manufactures nor imports chemicals, such responses are invariably simple negatives.

\section{FFCA}

In February 1992, an FFCA between DOE and USEPA Headquarters became effective that addresses PCB issues common to all three DOE uranium enrichment plants. Several compliance issues were resolved. These issues included the use of PCBs in non-totally enclosed systems, the storage of radioactive/PCB waste in accordance with nuclear criticality safety requirements, and the storage of radioactive/PCB waste for longer than one year. As of the end of CY 1993, Portsmouth is in full compliance with the requirements and milestones of this FFCA.

A quarterly status report is compiled and submitted to DOE regarding progress toward the milestones specified in the FFCA. An annual compilation of these status reports is submitted to the USEPA. In addition, DOE and USEPA representatives meet quarterly to resolve any unanticipated issues or uncertainties regarding the terms of the agreement.

\section{Federal Insecticide, Fungicide, and Rodenticide Act}

No restricted-use pesticides are used by Portsmouth personnel. When application of a restricted-use pesticide is required, a certified contractor is used. General-use pesticides applied by plant personnel are used in a manner consistent with product labeling; all product warnings and cautions are strictly obeyed. Application of pesticides by plant and contractor personnel must be approved by the plant pesticide coordinator.

\section{Clean Air Act and NESHAP}

As of the end of 1993, Portsmouth had 9 state air permits (permits to operate), 86 registered sources ("registered" sources are listed by the OEPA in lieu of receiving a formal permit), and 84 exempt sources. An additional 216 permit applications were awaiting action by the OEPA. No violations of air permit limits occurred during 1993. Portsmouth operates continuous opacity monitors on all three boilers at the X-600 steam plant.

Portsmouth is in compliance with the $10 \mathrm{mrem} /$ year radiological emission limit established by the USEPA; 1993 emissions were $0.9 \mathrm{mrem} / \mathrm{year}$. The 14 most significant radionuclide emission sources are monitored by continuous vent samplers for radionuclides and fluorides. In most cases, emissions from these 14 sources are below the level where continuous emission sampling is required. Stack tests for radionuclide emissions have been conducted on six minor sources. Emissions from other minor sources are estimated based on process knowledge and the emission factors in Appendixes D and E of 40 CFR 61.

On March 16-19, 1993, the USEPA conducted an inspection of Portsmouth for compliance with 40 CFR 61, Subpart H, National Emission Standards for Emission of Radionuclides Other than Radon from Department of Energy Facilities (Subpart H, NESHAP). Sixteen items of concern were noted. Monthly status reports are being submitted to DOE until the outstanding findings noted in the report are complete.

\section{Title III-Air Toxics Program}

The stack and vent survey is being reviewed for applicability of Title $\mathrm{II}$ regulations. Maximum achievable control technology standards are reviewed for applicability when issued by the USEPA; none have been applicable.

\section{Title V-Permit Program}

Portsmouth is a major. source because of its steam plant emissions and will have to obtain a Title $\mathrm{V}$ permit. The stack and vent survey has been completed and is being reviewed for any sources that may need to be issued permits. Emission estimates are made for newly discovered sources, and applications are submitted under the existing permit program. 


\section{Title VI-Stratospheric Ozone Protection}

Several activities are proceeding to enable compliance with Title VI of the Clean Air Act amendments. These activities include:

- The three-site Freon Replacement Committee is addressing the possibility of replacing the CFC-114 in the gaseous diffusion cascade with $\mathrm{C}_{4} \mathrm{~F}_{10}$.

- The X-720 compressor shop vapor degreaser has been decommissioned and is scheduled to be replaced with a steam booth.

- Hand degreasing operations now use aqueous solvents such as Blue Gold cleaner or non-listed organic solvents such as ethyl alcohol.

- Two CFC-12 air conditioners in the X-530 and X-533 switchyards were replaced with CFC-22 units.

- Portsmouth has purchased 12 refrigerant recovery/recycling units for use with conventional refrigeration equipment and 1 for use with automotive sources. In addition, Portsmouth has four recovery/recycling units for CFC-114 that were installed when the plant was built and that meet current USEPA regulations.

- Engineering projects and purchase requests are reviewed to ensure that new equipment uses the refrigerant with the least impact on the ozone layer.

\section{Clean Water Act}

As of the end of 1993, Portsmouth had a single NDPES permit covering the entire site. This permit encompasses 21 monitored outfalls, 14 of which are classified as point source discharges to waters of the state. The remaining seven outfalls are classified as internal outfalls, effluents from which go through another monitored outfall before reaching the waters of the state. DOE and USEC worked together as co-permittees to maintain compliance with the terms of the permit.

Compliance rates (by individual parameter) at NPDES outfalls.ranged from 83 to $100 \%$. The overall sitewide compliance rate for CY 1993 was $99.4 \%$. (The compliance rate is calculated by dividing the number of measurements that did not exceed the applicable permit limits by the total number of measurements made.)

\section{Safe Drinking Water Act}

Portsmouth operates 30 potable water wells located in 4 well fields and can also use surface water from the Scioto River. Portsmouth operates a lime-softening water treatment facility with a maximum daily flow of 40 million gallons per day (Mgd) to treat incoming water to potable standards. Current daily flow is approximately $16 \mathrm{Mgd}$; approximately $3 \mathrm{Mgd}$ is used as sanitary water, and the remainder is used for fire prevention and for recirculating cooling water systems.

Portsmouth routinely monitors the water system to ensure compliance with a number of operational requirements, including those for coliform bacteria, gross alpha and beta radiation, volatile organic chemicals, and the maximum-contaminant-level compliance package. All sample results are forwarded to the OEPA for review. Portsmouth operations are evaluated annually by the OEPA. No findings for violations of chemical, bacteriological, or radiological parameters have been noted for a number of years.

\section{National Environmental Policy Act (NEPA)}

NEPA requires evaluation of the environmental impacts of activities at federal facilities and of activities funded with federal dollars. NEPA reviews are required for all projects to determine the potential for environmental impacts related to the following:

1. property (e.g., sites, buildings, structures, and objects) of historic, archaeological, or architectural significance, as officially designated by federal, state, or local governments, including those eligible for listing on the National Register of Historic Places;

\section{2-6 Environmental Compliance}


2. the potential habitat (including critical habitat) of federally listed endangered, threatened, proposed, or candidate species or of state-listed endangered and threatened species;

3. federally listed endangered, threatened, proposed, or candidate species or state-listed endangered and threatened species;

4. floodplains and wetlands;

5. natural areas such as federally and state-designated wilderness areas, national parks, national natural landmarks, wild and scenic rivers, coastal zones, state and federal wildlife refuges, and marine sanctuaries;

6. prime agricultural lands; and

7. special sources of water (such as class I groundwater, sole-source aquifers, wellhead protection areas, and other water sources that are vital to a region).

Impacts to air, surface water, groundwater, biota, socioeconomics, and worker safety and health are also reviewed.

Portsmouth has a formal program dedicated to compliance with NEPA pursuant to revised DOE Order 5440.1E, National Environmental Policy Act Compliance Program. Remedial actions and waste management activities are evaluated to determine the appropriate level of NEPA documentation. NEPA documents are produced by NEPA compliance program personnel and are submitted to DOE for evaluation and approval. (Note: environmental impact statements must be produced by an independent organization.) Routine operations and maintenance activities are evaluated to assess potential environmental impacts. Most activities performed on-site qualify for categorical exclusion as defined in $10 \mathrm{CFR} 1021$ and listed in Subpart D, sections $A$ and $B$, of the DOE NEPA guidelines. These activities are considered to have no significant individual or cumulative environmental impacts. Numerous categorical exclusions were applied to Portsmouth activities during CY 1993. Environmental assessments were developed for projects relating to the construction of a new solid waste landfill and construction of a TSCA waste storage unit.

An environmental impact statement for Portsmouth was completed in 1977. Subsequent interpretations of environmental laws have led Portsmouth to initiate surveys for floodplains/wetlands, cultural resources, prime farmlands, and threatened and endangered species. Preliminary studies in each of these areas have been initiated. Completion is contingent upon funding of budget requests. Negotiations have been initiated with the Ohio State Historic Preservation Officer. The outcome of these talks will determine the need for a site-wide historical survey. Plans are also being finalized for a threatened and endangered species survey and wetland and floodplain delineation. No specific instance of regulatory noncompliance has been identified for any of these areas.

On July 1, 1993, the USEC formally began operations of facilities leased from DOE to enrich uranium for commercial purposes. In accordance with the USEC Environmental Review Policy published in the Federal Register (Vol. 58, No. 233, December 7, 1993), USEC also continues to evaluate routine operations, waste management, maintenance, and engineering project activities for environmental impacts.

\section{Other Environmental Acts}

\section{Endangered Species Act}

The Endangered Species Act of 1973, as amended, provides for the designation and protection of rare and threatened wildlife and plants. The act also serves to protect ecosystems on which such species depend. Field surveys are performed, and mitigating measures are designed as needed. When appropriate, formal consultations with the U.S. Fish and Wildlife Services and the Ohio Department of Natural Resources are made through DOE.

\section{National Historic Preservation Act}

The National Historic Preservation Act of 1966 is the primary law governing the protection of cultural resources (archaeological and historical properties). DOE and Portsmouth are in the process of developing procedures to ensure compliance with the act. Cultural resource reviews are conducted on a case-by-case basis, and consultations with the Ohio State Historic Preservation Officer are made through DOE as required by Section 106 of the act. 


\section{Compliance with Floodplain/Wetlands Environmental Review Requirements (10 CFR 1022)}

The DOE Compliance with Floodplain/Wetlands Environmental Review Requirements establish policy and procedures for compliance with Executive Order 11988, "Floodplain Management," and Executive Order 11990, "Protection of Wetlands." Activities proposed in wetlands or within 100-year and 500-year floodplains (other than routine maintenance) first require that a notice of involvement be published in the Federal Register. Then a wetlands assessment and/or floodplain assessment must be prepared and submitted to DOE for approval. These assessments must discuss the efforts of the proposed project on the wetland or floodplain and any alternatives or mitigating measures that would lessen adverse impacts. For floodplains, a floodplain statement of findings summarizing the floodplain assessment must also be approved by DOE and published in the Federal Register for public comment at least 15 days prior to beginning the project.

Portsmouth submitted one floodplain assessment to DOE for approval in 1993. A wetland assessment was incorporated in an environmental assessment relating to a proposed sanitary landfill. The assessment had not yet been approved as of the end of 1993.

A notice of involvement regarding floodplain/wetlands was published in the Federal Register in October 1993.

\section{Farmland Protection Policy Act}

The Farmland Protection Policy Act of 1981 requires federal agencies to consider the effects of their proposed actions on prime farmland. Prime farmland is generally defined as land that has the best combination of physical and chemical characteristics for producing crops of statewide or local importance. When required, prime farmland surveys are conducted, and consultations with the U.S. Department of Agriculture's Soil Conservation Service are made through DOE. No prime farmland surveys were conducted at Portsmouth in 1993.

\section{Ohio Agreement in Principal}

On October 26, 1993, an agreement in principal became effective between DOE and the state of Ohio regarding joint oversight of the three DOE facilities in Ohio (Fernald Environmental Restoration Project, Mound Laboratories, and Portsmouth). The agreement provides approximately $\$ 11 \mathrm{M}$ over a five-year period to the state to be used to review the environmental compliance and monitoring programs and data, supplement existing state and local emergency management programs, and promote better state and public understanding of DOE environmental activities at the three plants. The grant authorization is expected to be approved in early CY 1994 .

The Fernald Environmental Management Project will be the lead facility for the agreement, and the OEPA will be the lead state agency. The Ohio Department of Health and the Ohio Emergency Management Agency will also be involved.

\section{DOE Orders}

\section{DOE Order 5400.1, General Environmental Protection Program}

DOE Order 5400.1 provides direction for compliance with the USEPA and state and local environmental regulations and establishes requirements for internal environmental protection programs. Portsmouth maintains compliance with federal, state, and local statutes through implementation of requirements found in the Clean Air Act, the Clean Water Act, RCRA, TSCA, the Safe Drinking Water Act, and other appropriate statutes.

The internal environmental protection programs mandate the creation of several environmental reports. Reports include the radioactive effluent and on-site discharge data report submitted annually to the Waste Information Systems Branch at the Idaho National Engineering Laboratory; the five-year plan required by the Office of Management and Budget Circular A-106; the annual site environmental report; and reports of significant nonroutine releases of hazardous substances consistent with DOE Order 5000.3B, Occurrence Reporting and Processing of Operations Information. A long-range environmental protection implementation plan (EPIP) is required to be prepared and updated annually. An environmental monitoring plan (EMP) is to be

\section{2-8 Environmental Compliance}


prepared, reviewed annually, and updated every three years. The EPIP defines specific environmental objectives, including the means and schedules for accomplishment. The EMP defines a comprehensive system to provide effluent monitoring and environmental surveillance of effluents from Portsmouth. The EMP is designed to meet federal and state regulatory requirements as well as those internal to Portsmouth and DOE. All environmental media are included in the monitoring program, including surface water, groundwater, air, earth, and biological media. A draft EMP has been issued. The final draft, was issued in June 1994. The EPIP was updated in 1993 as required. Hence, Portsmouth is in partial compliance with this DOE order.

Quality assurance and data evaluation are primary considerations for Portsmouth monitoring, surveillance, sampling, and analytical activities. Independent data verification is conducted. This area is targeted for increased attention in the future. Audits of monitoring and sampling activities by state and federal regulatory agencies have been positive, and no significant findings have been issued.

\section{Waste Minimization}

Radioactive waste minimization efforts include segregation of radioactive and nonradioactive wastes; reduction of radioactive controlled areas, with an associated reduction in use of disposable personal protective equipment; and improved segregation and handling of radioactive laboratory wastes.

Combined hazardous/radioactive mixed waste minimization efforts include sorting of burnable wastes from radioactive contaminated wastes, reduction of absorbent cloth use in PCB spill cleanup, reduction in floor sweeping waste generated in process buildings, and the material substitution program.

Nonhazardous waste minimization efforts include a sanitary waste recycling program that includes recycling aluminum cans and corrugated cardboard.

Proposed future projects for waste minimization include pursuing permission from the OEPA to discontinue treatment of purge water from non-contaminated groundwater wells, elimination of vapor degreasing operations, consideration of latex-based paints in the paint shop, expansion of the recycling program to include paper, and reevaluation of existing RCRA hazardous and mixed waste streams under the site-wide process waste assessment program.

The development of waste minimization teams in each division and continuation of waste minimization training for all employees is expected to identify further waste minimization opportunities.

\section{Pollution Prevention}

Pollution prevention activities are administered at Portsmouth through the Pollution Prevention Awareness Program. The purpose of this program is to foster the philosophy that prevention is superior to remediation. The goal of the program is to incorporate pollution prevention into the decision-making process at every level throughout the organization. The program, required by DOE Order 5400.1, has been incorporated into the site Waste Minimization Program because both programs have compatible goals and program elements.

The Pollution Prevention Awareness Program consists of four elements: (1) the pollution prevention awareness campaign; (2) awards, recognition, and performance indicators; (3) information exchange; and (4) training. The existence of other pollution prevention measures, such as the Best Management Practices Plan and the Portsmouth Spill Prevention, Control, and Countermeasures Plan, are recognized as elements of pollution prevention.

A site-wide pollution prevention campaign was conducted in April 1993. Reductions in trichloroethane usage were achieved by decommissioning a vapor degreaser and substituting non-trichloroethane products. New freon reclamation units were purchased for more efficient removal and exchange. Other pollution prevention activities relate to the actions of the Stratospheric Ozone Protection Committee and the Freon Committee programs, which are addressing potential substitutes for CFC-114.

\section{Environmental Training}

Environmental training is a continuous process at Portsmouth. During 1993, training included environmental compliance, hazardous waste operations, RCRA, and PCB training. Hazardous waste operations training is conducted at three levels, including a 24-hour course, a 40-hour course, and an 8-hour refresher course, and is provided by the Energy Systems Training and Development staff. This training satisfies occupational safety and 
health requirements specified in $29 \mathrm{CFR}$ 1910.120. RCRA training courses are specific, dealing with hazardous waste generators and treatment, storage, and disposal operations. This training satisfies RCRA requirements specified in 40 CFR 165.16 and OAC-3745-55-16(D). Training related to the handling of PCBs is conducted to ensure that plant operations are performed in a safe and professional manner.

\section{Groundwater Protection Program}

\section{Scope of the Groundwater Protection Program}

DOE Order 5400.1 outlines requirements for groundwater monitoring at all DOE facilities and specifies the development of three individual documents relating to groundwater monitoring: an EMP, a groundwater protection program management plan (GWPPMP), and a groundwater monitoring plan. The GWPPMP formalizes and structures the Portsmouth Groundwater Protection Program (GWPP) by identifying and assigning specific roles and responsibilities to the various entities within the plant who are matrixed to the program. This document meets the requirements for a GWPPMP as described in DOE Order 5400.1. The contents of this plan have been updated and assembled to reflect the following scope:

- Define the purpose, policies, objectives, and history of the GWPPMP.

- Define regulations, requirements, and guidance applicable to groundwater monitoring at Portsmouth.

- Provide a brief description of the hydrogeologic conditions and known groundwater contamination at Portsmouth.

- Describe the groundwater monitoring strategies used at Portsmouth to meet the applicable regulations and requirements.

- Define the organizational roles and responsibilities of the GWPP, including interfaces with other programs.

- Define the documentation required for GWPP projects.

- Provide the most effective overall management possible for the GWPP.

This GWPPMP is a dynamic document that will be routinely updated and revised. The format has been designed to provide for the updating of individual sections independent of the rest of the document. The plan as a whole will be reviewed annually and will be revised and reissued every three years. Sections that are revised between reissue dates will be numbered and dated. Where appropriate, the GWPPMP incorporates material by reference. All referenced materials are subject to annual review, revision, and reissue.

\section{Purpose, Policies, and Objectives of the Portsmouth GWPP}

The purpose of the Portsmouth GWPP is to characterize the hydrogeology and monitor the groundwater quality at Portsmouth and its surrounding environs. These tasks are conducted primarily in support of (1) environmental surveillance activities conducted by the Environmental Restoration and Waste Management Division; (2) land disposal units requiring groundwater monitoring under RCRA; (3) the Remedial Action Program, which includes RCRA corrective action; (4) UST monitoring; and (5) land disposal units requiring groundwater monitoring under state solid waste regulations (OAC-3745-27).

Support for these programs is provided in many forms, including technical advice and assistance, well installation and development, sampling and analysis, data management, data interpretation, report preparation, regulatory negotiation, and implementation of monitoring and corrective actions.

The policy of the Portsmouth GWPP is dictated by MMES Policy Procedure ESH-14, "Environmental Protection and Waste Management." GWPP policy is to provide for protection of groundwater resources at Portsmouth consistent with federal, state, and local requirements and in accordance with DOE orders and MMES corporate policy.

The objective of the GWPPMP is to provide management and coordination support to the noted programs consistent with the stated policy in the most efficient, technically sound, cost-effective, and timely manner possible. Principal areas of activity for the GWPP include coordinating and/or conducting characterization studies of the subsurface and ensuring the proper level of review and interpretation of relevant data. 


\section{Groundwater Investigations at Portsmouth}

Several investigations have been conducted at.Portsmouth to determine the extent of groundwater contamination.

The most recent groundwater investigations at Portsmouth were conducted as part of the RFI that was initiated in 1989 in response to a consent order issued September 27, 1989, by the USEPA. The major part of the investigation was to characterize and define the sources and extent of groundwater contamination sufficiently to support the corrective measures study. The RFI separated Portsmouth into four distinct quadrants because of the large number of waste management units to be investigated and the nature of the groundwater flow system in the Gallia aquifer.

The final draft reports of the findings of the RFI were completed for quadrants I and II in February 1992 and Quadrant III in December 1992 (Geraghty and Miller 1989). The corrective measures study identified the need for additional sampling to be conducted in the future for quadrants I, II, and III. Field investigations associated with the RFI for quadrant IV have been completed. Data review and analysis and report preparation are under way.

\section{DOE Order 5400.5, Radiation Protection of the Public and the Environment}

DOE Order 5400.5 provides guidance and establishes radiation protection standards and control practices designed to protect the public and the environment against undue risk from operations of DOE and DOE contractors. The order requires that off-site radiation doses not exceed $100 \mathrm{mrem} / \mathrm{year}$. In CY 1993 the total off-site dose was $0.9 \mathrm{mrem} / \mathrm{year}$, including airborne emissions, consumption of locally produced foodstuffs (including fish caught in the Scioto River), and consumption of drinking water from the Scioto River.

Portsmouth is also well below all applicable media-specific dose limits, such as the USEPA limit of $10 \mathrm{mrem} / \mathrm{year}$ from airborne emissions and the DOE-derived concentration guides for specific nuclides in wastewater and storm water discharges. Portsmouth conducts various modeling and dose assessment activities to address the potential for multiple pathway exposures of the public. Portsmouth is in compliance with the requirements of DOE Order 5400.5.

\section{DOE Order 5820.2A, Radioactive Waste Management}

DOE Order 5820.2A became effective September 26, 1988. The purpose of the order is to establish policies, guidelines, and minimum requirements for which DOE manages its radioactive waste and contaminated facilities.

All radioactive wastes generated at Portsmouth are classified as low-level waste (LLW) or mixed waste and are subject to DOE Order 5820.2A, Chap. III, "Management of Low-Level Waste." DOE Order' 5820.2A requires that all radioactive wastes be treated, stored, or disposed of at DOE facilities. Facilities have been identified for this purpose (e.g., Hanford and the Nevada test site), and procedures and protocols are being established to provide proper access to these facilities. Portsmouth has initiated shipments to Hanford and is in the process of qualifying itself as an "Approved Hanford Generator" with a certification program.

Commercial facilities are becoming available for these activities (treatment, storage, and disposal), and DOE has provided a method of approving usage of these facilities for small quantities of waste. Volume reduction of LLW is provided by a commercial facility in Tennessee, and disposal of LLW and mixed waste is provided by a commercial facility in Utah. Portsmouth is proceeding to use the recently negotiated nationwide contract between DOE and Envirocare of Utah, Inc., for disposal of mixed waste.

LLW is segregated into four primary waste types according to applicable treatment technology and/or regulatory requirements. These waste types are: (1) burnables, (2) scrap metal, (3) other nonburnables, and (4) mixed (RCRA/LLW and PCB/LLW). Storage requirements for each of these waste types diminish the potential for environmental release, but eventually the nation will have to identify and deploy disposal facilities. Portsmouth is in compliance with the requirements of DOE Order 5820.2A. 


\section{Occurrences Reported to Regulatory Agencies}

Portsmouth is required to evaluate spills and unanticipated releases to determine if such incidents are reportable as prescribed in 40 CFR 302.6. In 1993 Portsmouth reported three releases that exceeded Comprehensive Environmental Response, Compensation, and Liability Act reportable quantities to the national, state, and local response centers as appropriate. These incidents were releases of:

1. approximately $15 \mathrm{gal}$ of ethylene glycol (antifreeze) from the $\mathrm{X}-100 \mathrm{~B}$ administration building airconditioning system to the floor;

2. approximately 1 quart of ethylene glycol from a company vehicle (number 8953) onto a parking area; and

3. approximately $10 \mathrm{gal}$ of ethylene glycol, from a surplus generator, being transported by truck to a concrete storage pad.

The potential to generate reportable-quantity releases exists at several Portsmouth operations. These include releases of fluorine associated with the uranium enrichment cascade, stack emissions from the coal-fired steam plant, spills of maintenance materials (such as antifreeze), and a variety of substances from contaminated groundwater associated with RCRA units. Estimates of potential releases from each of these sources have been calculated. Fluorine releases from the cascade, stack emissions from the steam plant, and contaminated groundwater releases from the RCRA units are not sufficient to constitute reportable-quantity releases. Spills and releases during 1993 are included in the chemical release data in Appendix C of this report.

\section{Compliance Audits of Environmental Programs}

During 1993, 22 audits, appraisals, inspections, or appraisals of the Portsmouth environmental programs were conducted. The most important are summarized as follows; a complete listing is in Table 2.2.

On September 22-23, the USEPA conducted a multimedia environmental audit that concentrated on the TSCA and Federal Insecticide, Fungicide, and Rodenticide Act programs. At the audit closeout, the inspector verbally expressed his satisfaction with Portsmouth compliance efforts, but no written report had been received as of the end of 1993.

USEPA Region V conducted a NESHAP compliance inspection on March 16-19, and the OEPA conducted the annual inspection of permitted air sources on August 19. No NOVs were generated from either of these inspections.

The annual RCRA compliance audit was conducted August 2-4 by the OEPA. All areas of compliance, including record keeping and compliance inspections required by RCRA regulations were reviewed. Portsmouth responded to all deficiencies identified during the audit. The OEPA issued an NOV based on its findings. (See the RCRA section for details of the NOV.)

\section{ENVIRONMENTAL PERMITS}

Table 2.3 lists the current environmental permit status for Portsmouth.

\section{Clean Air Act Permit Status}

At the end of 1993, Portsmouth had nine permits to operate associated with air emission sources. Currently, there are also 86 registered sources, 84 exempt sources, and 216 pending permit applications associated with air emission sources.

\section{Clean Water Act Permít Status}

A new NPDES permit was issued on September 23, 1991, and was modified on December 12, 1991, and June 1, 1993. The permit was also amended on September 3, 1993, to add USEC as a co-permittee with DOE. 
Table 2.2. Environmental audits and inspections during CY 1993

\begin{tabular}{|c|c|c|}
\hline Date & Auditor & Type \\
\hline January & $\begin{array}{l}\text { Portsmouth Internal Audit } \\
\text { Department }\end{array}$ & $\begin{array}{l}\text { Internal audit of environmental management } \\
\text { program }\end{array}$ \\
\hline Jan. $12-14$ & $\begin{array}{l}\text { DOE Headquarters } \\
\text { (DOE-HQ) }\end{array}$ & Appraisal of NPDES program/air program \\
\hline Jan. 19-21 & $\begin{array}{l}\text { Hanford/DOE-HQ/ } \\
\text { Westinghouse }\end{array}$ & $\begin{array}{l}\text { LLW shipment evaluation and acceptance } \\
\text { inspection }\end{array}$ \\
\hline Feb. 2-June 30 & DOE/USEC & Environmental baseline audit \\
\hline March $10-11$ & DOE-HQ & $\begin{array}{l}\text { Groundwater monitoring program } \\
\text { audit/evaluation }\end{array}$ \\
\hline March 16-19 & USEPA Region V & NESHAP compliance inspection \\
\hline March 17 & Public Health Department & Quarterly inspection of X-735 sanitary landfill \\
\hline March 18 & DOE-HQ & Residential water sampling evaluation \\
\hline April 8 & $\mathrm{DOE} / \mathrm{FERC}^{a}$ & Annual safety inspection of on-site dams \\
\hline April 27 & NOAA-INEL ${ }^{b}$ & $\begin{array}{l}\text { Evaluation of on-site meteorological } \\
\text { monitoring }\end{array}$ \\
\hline May 10 & Martin Marietta Corporate & Corporate environmental compliance audit \\
\hline May 27 & Public Health Department & Quarterly inspection of X-735 sanitary landfill \\
\hline June 10 & DOE-HQ & Groundwater monitoring evaluation \\
\hline July 19 & OEPA & Annual inspection of permitted air sources \\
\hline Aug. $2-4$ & OEPA & Annual RCRA compliance inspection \\
\hline Sept. $22-23$ & USEPA Region V & Annual multimedia audit \\
\hline Oct. 25-Nov. 2 & DOE & DOE independent safety assessment \\
\hline Nov. $15-19$ & Martin Marietta Corporate & $\begin{array}{l}\text { Annual corporate environmental compliance } \\
\text { audit }\end{array}$ \\
\hline
\end{tabular}

${ }^{a}$ Federal Energy Regulatory Commission.

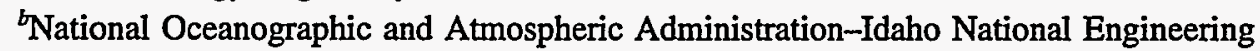
Laboratory.

This permit will remain in effect until July 29, 1994. A new permit is scheduled to be issued to Portsmouth during 1995 based on separate permit applications submitted by DOE and USEC.

\section{Sanitary Landfill License}

Portsmouth has one on-site sanitary landfill that is licensed by the state of Ohio.

\section{RCRA Permit Status}

In March 1993 the OEPA submitted the RCRA Part B permit application to the Ohio Hazardous Waste Facility Board, which is reviewing the permit. This is a formal, legal process, and subsequent hearings will be held before the permit is issued. 
Table 2.3. Portsmouth environmental permits

\begin{tabular}{lcc}
\hline \multicolumn{1}{c}{ Permits } & $\begin{array}{c}\text { No. permits } \\
\text { applied for }\end{array}$ & $\begin{array}{c}\text { No. permits } \\
\text { received }\end{array}$ \\
\hline Air & 216 & $9(86)^{a}$ \\
NPDES & & 1 \\
Sanitary landfill license & & 1 \\
RCRA & 1 & \\
\hline
\end{tabular}

${ }^{a}$ Air sources registered by the OEPA in lieu of formal permits to operate.

\section{CURRENT ISSUES}

In addition to the general trends discussed previously, a number of specific compliance issues have been identified. Although they remain unresolved, they are well defined, and actions necessary for their resolution have been initiated.

\section{RCRA NOVs}

In 1993 two NOVs were issued by the OEPA. The NOVs were issued for five violations found during the annual RCRA inspection and for an equipment problem related to an interim remedial measure. In addition, the USEPA issued one NOV for deficiencies in the Air RFI. A more detailed description of the NOVs is provided in the RCRA section under "Notices of Violation."

\section{Land Disposal Restriction (LDR) Waste}

Portsmouth is currently storing RCRA hazardous waste and low-level radioactive RCRA hazardous waste. This waste is subject to RCRA land ban provisions, which permit storage only to attain sufficient quantities to facilitate proper treatment, recycling, or disposal. Much of this waste is stored because of the nationwide shortage of treatment and disposal facilities. Because the nation's treatment capacity for radioactive mixed waste is inadequate, a national capacity variance was obtained that extended the effective date of LDR prohibitions until May 8, 1992. The national capacity variance did not extend to radioactive mixed waste containing solvents, dioxins, or California-listed wastes.

USEPA Region V informed Portsmouth in a letter dated March 30, 1992, that any LDR compliance issues involving mixed wastes should be discussed with the OEPA. The OEPA issued a Director's Findings and Orders to Portsmouth allowing the storage of LDR wastes for periods longer than one year while negotiations for long-term resolution are being conducted.

\section{X-735 Sanitary Landfill}

The X-735 sanitary landfill is the only permitted solid waste facility at Portsmouth. Portsmouth is in compliance with its permit for disposal of sanitary waste. A license to operate the landfill is obtained annually from Pike County, Ohio. Wastes permitted in the X-735 landfill include cafeteria wastes, industrial wastes, disinfected medical wastes (except drugs), construction and demolition debris, and asbestos (in designated locations). No hazardous wastes, TSCA wastes, or radioactive wastes are permitted in this facility. Asbestos disposal is conducted in accordance with NESHAP and OAC 3745-20.

The Portsmouth construction spoils area (X-736), located immediately west of the X-735 sanitary landfill, is an operating landfill for materials not regulated as solid wastes by the state of Ohio. Materials of this type include certain construction and demolition debris that do not contain hazardous or toxic substances. 


\section{PCB-Contaminated Lubricating Oil}

When testing began in 1980 , eight of the large (16,000 to 20,000 gal each) lubricating/hydraulic oil systems at Portsmouth were found to be contaminated with PCBs in excess of $50 \mathrm{ppm}$. Under the FFCA negotiated between DOE and the USEPA, Portsmouth was required to drain the oil from these systems for disposal by the end of March 1993. Later clarifications of the FFCA also established standards for reclassifying the systems as non-PCB items. The last of the eight systems was drained in late February 1993, and the oil was shipped to the DOE TSCA incinerator in Oak Ridge, Tennessee, for disposal. All eight systems now meet the USEPA standards for reclassification and have been restored to service.

\section{Ohio Permits to Operate}

Under OAC 3745-15, virtually any substance released into the atmosphere is an air pollutant and requires the submission of an application for a permit to operate to the OEPA. Portsmouth had 216 applications pending at the end of CY 1993.

\section{NESHAP}

The 14 most significant radionuclide emission sources at Portsmouth are monitored by continuous stack samplers. Stack tests for radionuclide emissions from one minor source, the X-720 motor shop burnoff oven, were conducted in September 1989 and May 1993. In 1987, stack tests for radionuclides were conducted on three sources in the X-705 decontamination facility and on two additional sources in the X-720 motor shop. Emissions from other minor sources are estimated based on process knowledge and Appendix D or Appendix $E$ of 40 CFR 61.

\section{CWA Compliance}

Rainfall runoff and algae growth have routinely resulted in total suspended solids and elevated $\mathrm{pH}$ exceedences. Draining ponds to reduce algae growth and lower $\mathrm{pH}$ values, adding carbon dioxide to ponds to control $\mathrm{pH}$ values, and dredging ponds to increase settling time are among the measures implemented to eliminate these occurrences. As a result of these efforts, exceedences decreased from 100 in 1991, to 46 in 1992, and to 44 in 1993. Of the 44 exceedences, 16 resulted from either total suspended solids or high pH limits being exceeded. Further decreases in exceedences are expected in 1994 because of the completion of dredging operations in late 1993 at the X-230K south holding pond, the X-230J-5 west holding pond, and the X-230J-7 east holding pond. 


\section{Environmental Program Information}

\section{Abstract}

The goal of the environmental programs at Portsmouth Gaseous Diffusion Plant is to assess the effects of Portsmouth operations on the environment and public health and to maintain the quality of the surrounding environment. Portsmouth has an extensive environmental monitoring program that consists of radiological and nonradiological monitoring of liquid and gaseous discharges, ambient air, surface water, groundwater, soil and sediment, and local biota. Monitoring is based on environmental regulations, critical pathways analysis, public concerns, and measurement capabilities. Other environmental programs at Portsmouth include waste management, environmental restoration, waste minimization and pollution prevention, training, information exchanges, and public and employee awareness.

\section{ENVIRONMENTAL MONITORING PROGRAM}

Because Portsmouth's primary mission is processing radiological materials, much of the environmental monitoring effort is directed toward collecting and analyzing samples for radioactive materials. Radioactive materials are regulated at the point of discharge and are monitored as they disperse into the surrounding environment. However, most radionuclides are released in such small amounts that it is not possible to detect them in a sampling medium, such as water, soil, or vegetation. For this reason, Portsmouth must use mathematical models to estimate the transport and dispersion of radionuclides into the environment. Basically, this involves monitoring the source of the contamination (i.e., the discharge stack or pipe) where higher concentrations than those found in a sampling medium may be readily obtained. Modeling can then be used to calculate the expected concentrations of contaminants in environmental media.

These models are also used to help optimize the effectiveness of the existing radiological monitoring program. For example, predictions based on models can be very beneficial in choosing the best locations for measuring devices and in identifying important pathways and contaminants. Modeling contributes to the best use of resources available for sampling and analysis and helps to verify that a sampling network is performing adequately.

Extensive monitoring is also conducted for nonradioactive contaminants. The nonradiological monitoring program is designed to ensure that the physical and chemical properties of atmospheric and liquid discharges comply with state and federal standards.

Monitoring requirements for liquid effluents vary at each outfall, or discharge point, depending on the type of facility and the known characteristics of the wastewater. In addition to monitoring liquid effluents, Portsmouth collects and analyzes samples from site streams and the Scioto River. This surveillance is designed to provide verification of outfall sampling and to ensure that materials that could adversely affect the environment are detected and properly characterized. Monitoring of nonradioactive constituents in atmospheric releases is designed to ensure compliance with permits issued by the Ohio Environmental Protection Agency (OEPA).

\section{Goals}

The Environmental Monitoring Program is designed for the assessment of Portsmouth operations on the environment and public health. This is accomplished through the collection and analysis of samples. The results are compared with defined standards. These results are used to gauge the environmental impact of Portsmouth operations and to set priorities for further environmental improvements.

\section{Rationale}

The justification for choosing certain environmental media to be sampled, specific sampling locations, sampling frequencies, and parameters is referred to as the rationale. Environmental regulations, critical pathways analyses, public concerns, and measurement capabilities must all be considered in the rationale for the establishment of a successful environmental monitoring program. The rationale for the establishment of the 
Portsmouth Environmental Monitoring Program is found in the Environmental Monitoring Plan for the Portsmouth Gaseous Diffusion Plant (MMES 1994).

\section{Environmental Regulations}

Numerous state and federal regulations that encompass radiological and nonradiological programs are drivers for much of the monitoring conducted at Portsmouth. These regulations include the National Emission Standards for Hazardous Air Pollutants, the National Pollutant Discharge Elimination System (NPDES), the Resource Conservation and Recovery Act (RCRA), and the National Environmental Policy Act. Compliance with these regulations requires a number of regulators, including the U.S. Environmental Protection Agency (USEPA) and the OEPA, which oversee various plant activities to help ensure compliance. In addition to these regulations are U.S. Department of Energy (DOE) orders in the 5400 series, in particular 5400.1, General Environmental Protection Program, and 5400.5, Radiation Protection of the Public and the Environment. A complete discussion of the site's compliance activities is in Section 2, "Environmental Compliance."

Acceptable levels of contaminants are generally specified in regulations relating to nonradioactive substances. Regulations relating to radioactive materials generally include limits for exposure to the public. As discussed in Section 6, "Dose," Portsmouth uses USEPA-approved mathematical models to estimate the dispersion of radioactive contaminants in the environment and resulting exposures to the off-site population.

\section{Critical Pathways Analysis}

Individuals may be exposed to airborne and liquid releases of radioactive and chemical materials in various ways. These routes are referred to as pathways. Environmental reports were examined to determine which radionuclides and exposure pathways are most important in terms of the quantity of radionuclides released, the dose received by the maximally exposed individual, and the collective dose received by the population. This type of analysis, called a critical pathways analysis, is a good indicator for determining which radionuclides and pathways at a particular site deserve the most attention. Critical pathways analyses have been used historically at Portsmouth as input for the Environmental Monitoring Program.

The following sections summarize the results of a critical pathways analysis of Portsmouth operations. The analysis includes radionuclide releases to the atmosphere and surface water, which are the principle media that might allow for the transportation of radioactive contaminants from the site.

\section{Air}

Air provides a potential exposure pathway to humans for radionuclides released into the atmosphere. Therefore, air sampling is conducted to evaluate the potential dose to local populations. Monitors measure radiological and nonradiological air emissions from individual buildings, specific facility locations, and surrounding communities. This information is used to help protect the health and safety of Portsmouth workers and the general public and to demonstrate compliance with state and federal air quality regulations. Both effluent air (air that flows from a specific source into the environment) and ambient air (existing air in the surrounding environment) are monitored.

\section{Surface Water}

Surface waters at Portsmouth are analyzed to ensure compliance with water quality standards, establish background water quality, evaluate the potential for contaminant releases, and to comply with monitoring regulations and permits. In addition, biological monitoring (characterization and monitoring studies) is conducted to demonstrate that effluent limitations established in permits provide for the future use of receiving streams as intended. Biological monitoring also helps document ecological impacts of past and current operations, identify contaminant sources that might adversely affect stream biotas, and provide baseline data that can be used to determine the effectiveness of remedial actions. 


\section{Summary of Radionuclides}

The three natural uranium isotopes $\left({ }^{234} \mathrm{U},{ }^{235} \mathrm{U}\right.$, and ${ }^{238} \mathrm{U}$ ) and ${ }^{99} \mathrm{Tc}$ are potentially significant when calculating the radiation dose received by the public around Portsmouth. All of these radionuclides have half-lives exceeding 200,000 years; consequently, the sampling frequency does not need to allow for radioactive decay. The types of radiations emitted vary from one radionuclide to the next. The predominance of beta and alpha emitters indicates the importance of monitoring internal exposures from possible ingestion or inhalation of radionuclides.

\section{Important Pathways for Radionuclides from Portsmouth}

Exposure to radioactive materials might occur from releases to the atmosphere, surface water, or groundwater. In addition, a dose might be received through direct external irradiation by radiation emanating from buildings and other objects (e.g., drum and burial areas) located within plant and reservation boundaries. Doses are estimated for all potentially significant exposure pathways relevant to the exposure modes just described.

\section{Implications of Pathway Analysis for Environmental Monitoring}

Models used to assess any environmental impact relating to the transport of and human exposures to substances released from Portsmouth must be appropriate for the situation encountered. Recorded data are used when available to ensure that any assessment is as accurate and realistic as possible. A complete set of potential human exposure pathways are considered in assessing radiological and chemical exposure. Those pathways of exposure to the most exposed individual and to the entire population residing within $80 \mathrm{~km}$ of Portsmouth are evaluated.

Each assessment is documented. A file is created that contains the results of each calculation, a description of models used, a description of any computer codes used to implement the models, and a complete list of the values and sources of all input data and assumptions used. Surface water and groundwater modeling are conducted as necessary to conform with applicable requirements of the state government and of the regional USEPA office.

\section{Public Concerns}

Although the actual amount of a substance released is of great concern to the public, its effect on the environment and public health is of even greater concern. Such concern can arise when a release could be transported to neighborhoods or schools. Concern can also exist for releases of long-lived radionuclides that remain in the environment for many years.

\section{Measurement Capabilities}

Many of the radioactive and nonradioactive materials released from Portsmouth exist in such low concentrations in the environment that they cannot be measured readily. Thus, measurement capabilities become determining factors in the rationale for monitoring certain materials. In these cases, modeling, as previously discussed, may be used to determine concentration levels.

\section{Environmental Monitoring Program Changes in 1993}

Environmental monitoring practices are reevaluated as new methods and the need for monitoring evolve. Types of measurements and their frequencies are reviewed routinely, and monitoring locations are sometimes changed. Environmental Monitoring Program changes in 1993 included the following:

- Per an OEPA special request of May 13,1993, an additional wastewater sampling program was initiated at four NPDES outfalls. Sampling began in July 1993 and continued through July 1994. Analyses included metal, organic, and radioactive parameters. These data were collected for a quantitative stream study 
performed by the Division of Water Quality Planning and Assessment and the Division of Emergency and Remedial Response. This information will be used in the upcoming NPDES permit negotiations.

- Portsmouth plans to upgrade the ambient air monitoring stations to comply with USEPA criteria for sampling particulate matter, which specify use of a high-volume sampler. The high-volume design is the recognized standard for particulate sampling. High-volume samplers have already been installed at three stations along the plant perimeter and at the background station near Otway. High-volume samplers were installed at two additional perimeter locations in early 1994. The remaining stations, if deemed useful, will also be upgraded as funding permits.

A comprehensive review of the Environmental Monitoring Program began in 1991, and The Environmental Monitoring Plan for the Portsmouth Gaseous Diffusion Plant was formulated. The plan, required by DOE Order 5400.1, was under review in 1993 and was submitted for approval in July 1994. The plan documents effluent monitoring and environmental surveillance activities conducted at Portsmouth. The plan also includes the rationale and design criteria for the Environmental Monitoring Program, the frequency of monitoring and analysis, specific analytical and sampling procedures, quality assurance requirements, and guidance on preparing and distributing reports.

\section{ENVIRONMENTAL QUALITY}

Maintaining the quality of the environment at Portsmouth and in the surrounding communities requires programs that involve several site departments and organizations. These programs are extensive and varied, involving not only site personnel but also members of the general public. Activities include waste management, environmental restoration, waste minimization and pollution prevention, environmental training, and information exchange and awareness programs.

\section{Waste Management Program}

The Portsmouth Waste Management Program directs the safe storage, treatment, and disposal of waste generated by past and present operations and from current environmental restoration projects. The primary objective is to ensure that waste materials do not migrate into the environment. Waste managed under the program is divided into six categories: low-level, hazardous, mixed, polychlorinated biphenyl (PCB) and PCBradioactive, asbestos, and conventional sanitary waste:

- Low-level waste-radioactive waste not classified as high-level or transuranic and that does not contain any components regulated by RCRA or the Toxic Substances Control Act (TSCA).

- Hazardous waste - waste that contains one or more of the wastes listed under RCRA or that exhibits one or more of the four RCRA hazardous characteristics: ignitability, corrosivity, reactivity, and toxicity.

- Mixed waste - waste containing both hazardous and radioactive components. Mixed waste is subject to RCRA, which governs the hazardous components, and to additional regulations that govern the radioactive components.

- $\quad P C B$ and $P C B$-radioactive wastes - waste containing PCBs, a class of synthetic organic chemicals including 209 known isomers, each with from 1 to 10 chlorine atoms on a biphenyl ring. Under TSCA regulations, PCB manufacturing was prohibited after 1978. However, continued use of PCBs is allowed provided that the use does not pose a risk to human health or the environment. Disposal of all PCB materials is regulated.

- Asbestos waste-friable asbestos materials from renovation and demolition activities.

- Sanitary waste - waste that is neither radioactive nor hazardous. Solid sanitary waste is basically refuse and is disposed of in landfills. Liquid sanitary waste includes sewage and industrial waste treated at the Portsmouth sewage treatment plant.

Waste management requirements are varied and are sometimes complex because of the variety of waste streams generated by Portsmouth activities. DOE orders and USEPA and Ohio Department of Health regulations 
must be satisfied to ensure compliance for waste management activities. Supplemental policies have been implemented for management of radioactive, hazardous, and mixed wastes. These policies include

- minimizing wastes;

- characterizing and certifying wastes before they are stored, processed, treated, or disposed of; and

- pursuing volume reduction and use of on-site storage when safe and cost effective until a final disposal option is identified.

\section{Environmental Restoration Program}

DOE established the Environmental Restoration (ER) Program to find, analyze, and correct site contamination problems as quickly and cost effectively as possible. The ER Program encompasses both inactive sites (remedial action) and active facilities (decontamination and decommissioning). Options for correcting or mitigating the contaminated sites and facilities include removal, stabilization, and treatment of contaminants.

The Portsmouth ER Program is designed to ensure that activities meet federal and state requirements (primarily RCRA) and DOE orders. The OEPA and USEPA oversee the Portsmouth ER Program through their respective agreements with DOE. The Ohio Consent Decree became effective August 31, 1989. The Administrative Order by Consent, between the USEPA and DOE, became effective November 1, 1989. These agreements establish a program of corrective actions to be taken and a schedule for its completion.

As required in these agreements, Portsmouth ER Program activities are conducted in accordance with the RCRA corrective action process, consisting of the following:

- RCRA facility assessment-to identify releases of contaminants and determine the need for further investigation.

- RCRA facility investigation - to determine the nature and extent of any contamination.

- Corrective measures study-to evaluate and select a remediation alternative.

- Corrective measures implementation-to implement the selected remediation measure.

- Interim remedial measures (IRMs)--to implement quick remediation or mitigation measures in advance of permanent action.

Because of the size of the facility and the nature of groundwater flow, the Portsmouth plant was divided into four quadrants for investigation and cleanup.

The Portsmouth ER Program was developed in 1989 and was granted an initial budget of $\$ 13.8 \mathrm{M}$. Since then, annual program expenditures have grown to $\$ 50-60 \mathrm{M}$. RCRA facility investigations have been completed for all quadrants, and corrective measures studies are being initiated. As a result of potential threats to human health and the environment, several IRMs were initiated. Of these, two IRMs have been completed and two others are being planned to address migration of contaminated groundwater.

\section{Waste Minimization and Pollution Prevention Program}

Portsmouth has combined its waste minimization and pollution prevention efforts to consolidate related activities. Objectives of the Portsmouth Waste Minimization and Pollution Prevention Program include

- fostering a philosophy to conserve resources and create a minimum of waste and pollution;

- promoting the use of nonhazardous materials in plant operations to minimize potential risks to human health and the environment;

- reducing or eliminating the generation of wastes through material substitution, product reformulation, process modification, improved housekeeping, and on-site closed-loop recycling; and

- complying with federal and state regulations and United States Enrichment Corporation-DOE policies and requirements for waste minimization. 
The Portsmouth Waste Minimization and Pollution Prevention Program continues activities to achieve the objectives just listed. Typical projects include

- maintaining a comprehensive waste tracking and reporting system;

- evaluating all plant processes and activities to identify waste minimization opportunities (e.g., conducting process waste assessments and identifying procedures that are barriers to waste minimization);

- maintaining an effective plant-wide waste minimization training program;

- maintaining a waste minimization and pollution prevention awareness promotional campaign; and

- providing a waste minimization and pollution prevention information exchange network.

\section{Environmental Training Program}

Portsmouth provides environmental training to increase employee awareness of environmental activities and to enhance the knowledge and qualifications of personnel performing tasks associated with environmental assessment, planning, and restoration. The program includes on- and off-site classroom instruction, on-the-job training, seminars, and specialized workshops and courses. Environmental training conducted or prepared by Portsmouth includes

- hazardous waste site training for workers;

- hazardous waste site training for managers/supervisors;

- RCRA training for treatment-, storage-, and disposal-facility workers;

- environmental laws and regulations training; and

- water/wastewater treatment training.

\section{Information Exchange Program}

To improve and update its environmental monitoring and research programs, Portsmouth has opened several avenues of information exchange between itself, other DOE facilities, and other sources of information.

\section{Technical Information Exchange}

Portsmouth representatives attend both DOE-sponsored and independent technical information exchange workshops such as the annual DOE Model Conference, quarterly multiplant task team meetings, and professional conferences.

\section{Public Awareness Program}

A comprehensive community relations and public participation program on the Environmental Restoration and Waste Management Program has been established since early 1990. The purpose of the program is to conduct a proactive public involvement program, with outreach components, to foster a spirit of openness and credibility among local citizens and various segments of the public. The program is also geared to provide the public with opportunities to become involved in the decisions affecting environmental issues at the plant.

DOE opened a public Environmental Information Center in February 1993 in an effort to provide public access to all documents used to drive decisions on remedial actions being taken at the plant. The information center has a full-time staff and is located about 10 miles north of the plant at 505 West Emmitt Avenue, Suite 3, Waverly, Ohio 45690 . The center's hours are 10 a.m. to 4 p.m., Monday, Tuesday, Wednesday, and Friday and 9 a.m. to 12 noon on Thursday, or after hours by appointment (614-947-5093).

A group of about 45 key stakeholders, composed of elected officials, community leaders, environmentalists, and other individuals who have expressed an interest in the Environmental Restoration and Waste Management Program, is targeted for information and input on current activities and those actions under consideration at the plant. Semiannual public update meetings are also held, as well as public workshops on specific topics to keep the public informed and to receive their comments and questions. Periodically, fact sheets about major projects

\section{3-6 Environmental Program Information}


are written for the public, and semiannual newsletters are printed and distributed to more than 4000 recipients, including the community relations mailing list, neighbors within two-miles of the plant, and all plant employees and retirees.

Points of contact have been established for the public to obtain information or direct questions regarding the Environmental Restoration and Waste Management Program. The Environmental Restoration Program manager for DOE is the primary point of contact at 614-897-5512. The Martin Marietta Energy Systems, Inc., site manager and the community relations manager also provide information on the program.

\section{Ohio Agreement in Principal}

The Ohio Agreement In Principal is a program originated by DOE in which DOE contributes funding to state agencies for resident state personnel to oversee environmental compliance at the three DOE facilities within the state of Ohio (the Fernald Environmental Management Project near Cincinnati; the Mound Plant, Miamisburg; and the Portsmouth Gaseous Diffusion Plant, Piketon). The lead state agency is the OEPA. 


\section{Effluent Monitoring}

Abstract

The release of airborne pollutants from Portsmouth Gaseous Diffusion Plant is regulated by permits from the state of Ohio and the U.S. Environmental Protection Agency. Although total airborne radionuclide discharges from Portsmouth increased during 1993 because of decontamination activities, discharges $(7.9 \mathrm{Ci})$ were well below applicable standards. The most significant nonradiological air pollutants from Portsmouth are smoke and sulfur dioxide from the X-600 steam plant, which achieved $100 \%$ compliance with permit limits for both pollutants.

The majority of liquid effluents from Portsmouth are regulated by the National Pollutant Discharge Elimination System (NPDES). A total of $0.72 \mathrm{Ci}$ of radioactivity was released to surface water. This total represents a decrease in uranium emissions and an increase in technetium emissions. However, because uranium has a significantly higher dose response, the net effect on the public radiation dose is negligible. For nonradiological releases, overall compliance with the NPDES permit limits was $99.4 \%$.

Portsmouth Gaseous Diffusion Plant (Portsmouth) practices a progressive environmental strategy for pollution control in compliance with requirements of the Clean Air Act and the Clean Water Act. This strategy uses modern pollution abatement technology followed by continual review of treatment facility performance to meet current regulations regarding airborne and liquid effluents in the most cost-effective manner.

\section{AIRBORNE DISCHARGES}

This section first briefly describes major radiological and nonradiological air emission sources and associated emission control and emission monitoring systems at Portsmouth. A summary of the total annual emission data and a discussion of its significance follow.

\section{Radiological Airborne Discharges}

The primary source of radiological discharges to the air at Portsmouth is the uranium enrichment cascade itself, which can release radionuclides through several process vents. In addition, the monitoring system also covers two supporting systems that are potentially significant contributors to total plant releases.

\section{Regulatory Requirements}

Airborne discharges of radionuclides from U.S. Department of Energy (DOE) facilities are regulated by the U.S. Environmental Protection Agency (USEPA) under the Clean Air Act and the National Emission Standards for Hazardous Air Pollutants (NESHAP). These regulations set an annual dose limit of $10 \mathrm{mrem} / \mathrm{year}$ to any member of the public as a result of airborne releases from DOE facilities, as well as certain minimum performance standards for demonstrating compliance with the dose limit.

Gaseous radionuclide discharges are also regulated, along with all other atmospheric pollutants, under the Ohio Permit-To-Operate regulations. However, Ohio does not yet have any standards governing radionuclide emission limits and defers to the federal NESHAP program instead of acting on permit applications filed by Portsmouth.

In addition to these outside authorities, DOE regulates radionuclide emissions to all environmental media through DOE orders 5400.1, General Environmental Protection Program, and 5400.5, Radiation Protection of the Public and the Environment. DOE Order 5400.5 sets an annual dose limit of $100 \mathrm{mrem} / \mathrm{year}$ to any member of the public. Unlike the NESHAP limit, the DOE limit includes all radionuclide releases from a facility. 


\section{Background}

The purge cascades use gaseous diffusion to continuously separate uranium hexafluoride $\left(\mathrm{UF}_{6}\right)$ from "lights" (i.e., light gases, primarily air) that have leaked into or otherwise entered the process. The $\mathrm{UF}_{6}$ is returned to the main cascade, and the "lights" are passed through activated alumina traps to remove residual traces of $\mathrm{UF}_{6}$ and other pollutants before being sampled and vented to the atmosphere.

Portsmouth uses two purge cascades known as the side-purge cascade and the top-purge cascade. Exhaust from both cascades is vented by dedicated air jets (T-jet and S-jet) or by a standby air jet (E-jet) that can be valved in to temporarily replace or supplement either of the regular air jets. All three jets are sampled by separate continuous samplers.

The cold recovery and wet-air evacuation systems are maintenance support systems in the X-330 and X-333 process buildings. Cold recovery systems are used to evacuate gases from cascade cells that must be opened for maintenance. Refrigerated "cold traps" are used to freeze out $\mathrm{UF}_{6}$, and noncondensable "lights" are passed through sodium fluoride traps and are vented to the atmosphere. After maintenance, the wet-air evacuation systems evacuate air from outside (i.e., "wet" air) through alumina traps before the cell is returned to service. In $\mathrm{X}-330$, both systems pass exhaust through a common roof vent with a single sampler. In X-333, the two systems have separate roof vents and samplers. Normally, these systems are minor emission sources, but the potential exists for unplanned releases.

Another emission source with a continuous vent sampler is the X-345 high-assay sampling area (HASA) vent, where cylinders of enriched $\mathrm{UF}_{6}$ are heated and sampled for quality control. To prevent sample mixing, the sampling manifold must be purged and evacuated after each set of samples. The evacuated gases are cold-trapped to recover residual uranium and are then vented through alumina traps. In addition, there is a suction device (i.e., a "gulper") behind the sample cylinders to collect any small releases during cylinder disconnections. The combined exhaust from both systems is sampled by a single continuous sampler. Routine emissions from the $\mathrm{X}-345$ HASA are small, but because the system handles liquid $\mathrm{UF}_{6}$ of high assay, the potential exists for a significant unplanned release.

The X-344 facility is also used to heat cylinders of $\mathrm{UF}_{6}$ either for sampling or for transfer between cylinders. Like the X-345 HASA, it possesses a combined vent for system evacuation and for a gulper that is monitored by a single continuous sampler.

The enrichment cascade is divided into six control areas, each of which has its own control room and seal exhaust station. The seal exhaust stations collect and vent in-leaked air from inside the shaft seals between the cascade compressors and their motors. The air passes through activated alumina traps, vacuum pumps, and oil traps (i.e., mist eliminators) before being vented. The seal exhaust station in X-333 (area 1) was equipped with a continuous sampler on an experimental basis in early 1989. As a result of the success of this sampler, continuous samplers were installed on the remaining five seal exhaust vents in late 1991 and began operating in 1992.

In addition to the continuous samplers, other systems monitor emissions from the cascade vents. Process control is based on real-time information provided by ionization-chamber-type instruments called "space recorders." Space recorders have limited sensitivity and cannot distinguish between uranium and technetium emissions, but they can provide qualitative information adequate for operating purposes. The space recorders are checked (every 4 hours on the purge cascades) by 5-L (1.3-gal) grab samples that are analyzed on a priority basis. Grab samples provide only limited information however, and some data suggest that the technetium concentrations in the grab samples may be biased high under some conditions. The grab samples are also less sensitive than the weekly samples, which represent several thousand liters of sampled vent gases. The Portsmouth plant laboratory is developing a modification of the continuous sampler that would use a pair of gamma detectors to measure uranium accumulation in the traps in real time. Major problems at present are background drift and a need to know the assay of the uranium emissions in advance.

\section{Sample Collection and Analytical Procedure}

Gaseous radionuclide and fluoride emissions from the purge cascade vents, the cold recovery and wet-air evacuation vents, the X-345 HASA vent, X-344 evacuation vent, and the six seal exhaust vents are sampled continuously by systems developed and built by the Portsmouth plant laboratory. The continuous vent samplers

\section{4-2 Effluent Monitoring}


draw a flow-proportional sample of the vent stream through two small alumina traps in series by way of an isokinetic probe. The primary sample traps are replaced weekly, and the secondary traps are replaced quarterly.

A waste stream analysis was performed to determine the radionuclides present on-site. These radionuclides are the naturally occurring isotopes ${ }^{234} \mathrm{U},{ }^{235} \mathrm{U}$, and ${ }^{238} \mathrm{U}$; two trace impurities from recycled uranium, ${ }^{236} \mathrm{U}$ and ${ }^{99} \mathrm{Tc}$; and equilibrium concentrations of short-lived uranium daughters. Alumina from the sampler is analyzed for total uranium, ${ }^{235} \mathrm{U}$, and technetium. The ratio of ${ }^{235} \mathrm{U}$ to total uranium (i.e., the "assay") and the process data are used to calculate the fractions of ${ }^{234} U$ and ${ }^{236} U$ in emissions. Because of their short half-lives, uranium daughter emissions cannot be reliably measured in weekly samples and are assumed to be in equilibrium with their parent nuclides. The uranium daughters included in the equilibrium calculations are ${ }^{234} \mathrm{Th},{ }^{231} \mathrm{Th}$, and ${ }^{234 m \mathrm{~Pa}}$.

\section{Results}

Radionuclide emissions from Portsmouth (Table 4.1) had no significant impact on public health or the environment. Total radionuclide emissions from Portsmouth increased in 1993 because of increased technetium emissions from decontamination activities (discussed in the following paragraphs). Mass emissions of uranium increased slightly (from 8.39 to $9.5 \mathrm{~kg}$ ), but the activity level dropped from 0.14 to $0.062 \mathrm{Ci}$ because of the much lower assay of the product. With the exception of technetium, there were no unplanned releases during 1993. Despite these increases, Portsmouth emissions still remained well below the applicable USEPA standard and far below the levels listed as safe by national and international regulatory bodies such as the Occupational Safety and Health Administration, the Nuclear Regulatory Commission, and the International Committee on Radiation Protection.

Table 4.1. 1993 Portsmouth radionuclide releases to air

\begin{tabular}{lll}
\hline \multicolumn{1}{c}{ Radionuclide } & \multicolumn{1}{c}{$\mathrm{kg} / \mathrm{year}$} & $\mathrm{Ci} /$ year \\
\hline${ }^{234} \mathrm{U}$ & 0.0093 & 0.057 \\
${ }^{235} \mathrm{U}$ & 0.697 & 0.0015 \\
${ }^{236} \mathrm{U}$ & 0.000101 & 0.0000064 \\
${ }^{238} \mathrm{U}$ & 8.81 & 0.0029 \\
Total uranium & 9.52 & 0.062 \\
${ }^{99} \mathrm{Tc}$ & 0.458 & 7.83 \\
Uranium daughters & $1.3 \times 10^{-10^{a}}$ & 0.0074 \\
\hline
\end{tabular}

${ }^{a} 0.00000000013$.

In 1992, Portsmouth stopped producing highly enriched uranium and began decontaminating the process equipment to safely place it in long-term shutdown. Once the decontamination process is complete, radionuclide emissions from Portsmouth will drop significantly compared with historical levels.

The initial work on this project began in mid-1992, when the main enrichment cascade was reconfigured to bypass the section that produced highly enriched uranium. In the last quarter of 1992, Portsmouth began to remove accumulated uranium deposits from equipment that had been taken out of service to preclude any possibility of a nuclear criticality incident in the unattended equipment. These cleanup activities continued through 1993. The decontamination process reconverts uranium deposits to gaseous $\mathrm{UF}_{6}$, which can be recovered without opening the process equipment. Unfortunately, this process also converts technetium inside the process equipment to a gaseous form. Prior to beginning the decontamination, it was not realized how much gaseous technetium was going to be generated in this manner.

Historically, uranium has accounted for 75 to almost $90 \%$ of the public dose from Portsmouth emissions. Consequently, the emission control systems on the cascade are optimized to reduce uranium emissions first and technetium emissions second. This approach was not capable of controlling the amount of gaseous technetium generated by decontamination operations. Consequently, technetium emissions, which were well below normal prior to October 1992, increased to ten times normal in November and December 1992. 
Portsmouth attempted to reduce these emissions by increasing the operation of the existing control systems (chemical absorption on activated alumina) but by the end of March 1993 concluded that this approach would not succeed. A committee was formed to identify more effective means of controlling technetium emissions, with priority on means that could be initiated quickly. Several steps were taken, including adding soda lime (a more effective adsorbent for technetium) at the inlet of the control systems. Administrative controls were also instituted. Technetium emissions continued above normal and peaked in June 1993; the emissions then fell until leveling off at normal levels in October 1993. In late 1993, a sidestream treatment using magnesium fluoride traps was added at the top of the cascade; however, the cell in which these traps were added had to be taken offline for repairs after a few weeks of operation. These measures have been effective so far: technetium emissions have remained low through February 1994. Additional engineering controls will be added in early to mid 1994.

Figures 4.1 through 4.3 show the Portsmouth emission levels for uranium and technetium over the last five years. Figures 4.1 and 4.2 show uranium emissions in curies (a measure of radioactivity) and kilograms (a measure of mass), respectively. Both figures are included because uranium is a mixture of three different isotopes $\left({ }^{236} \mathrm{U}\right.$ is a trace contaminant) with widely varying specific activities, producing varying levels of curies per kilogram. Because of this, $1 \mathrm{Ci}$ of uranium can weigh from $9 \mathrm{~kg}(19.8 \mathrm{lb})$ to 3 metric tons $(6600 \mathrm{lb})$, depending on the proportions of isotopes present. For the future, it is expected that mass emissions (kilograms) of uranium will remain about the same as levels seen from 1989 through 1993, and the activity emissions (curies) of uranium should decrease after 1993 because of the absence of highly enriched uranium in the emissions.

Figure 4.3 shows technetium emissions in curies. Because only one isotope of technetium is present at Portsmouth, a figure showing mass emissions would provide no information not found in Fig. 4.3. Mass emissions of technetium from Portsmouth in 1993 were $460 \mathrm{~g}(0.46 \mathrm{~kg})$.

Emissions of uranium daughters have ranged from 0.028 to $0.002 \mathrm{Ci} /$ year since 1986 and have never made a significant impact on the environment or public health. Emissions during 1993 were $0.007 \mathrm{Ci} / \mathrm{year}$.

\section{Nonradiological Airborne Discharges}

Portsmouth operations also release various nonradiological substances to the atmosphere. Fluorides are present in the cascade vents as various reactive fluoride gases, including $\mathrm{UF}_{6}$ and hydrogen fluoride (HF). These emissions are monitored directly with the continuous vent samplers. In addition, several types of airborne emissions are calculated from process data or from purchasing records.

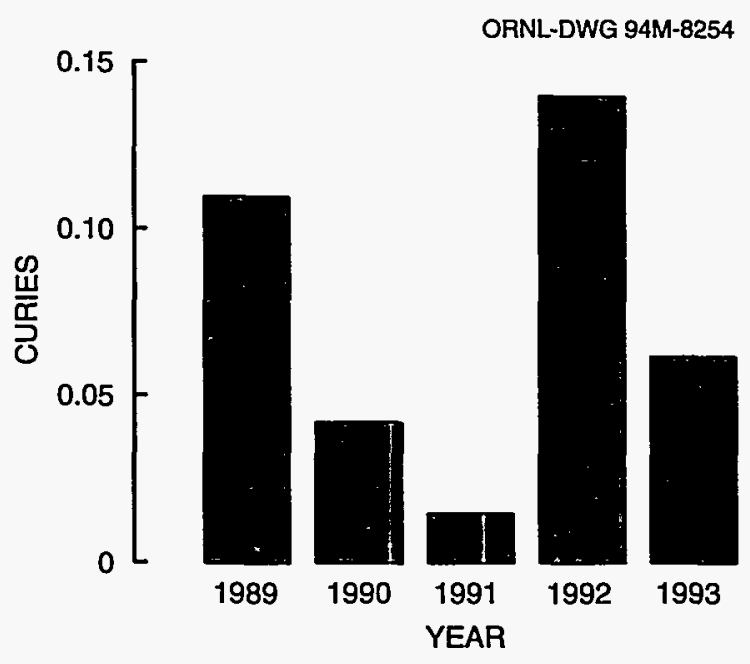

Fig. 4.1. Total curies of uranium discharged to air.

\section{4-4 Effluent Monitoring}




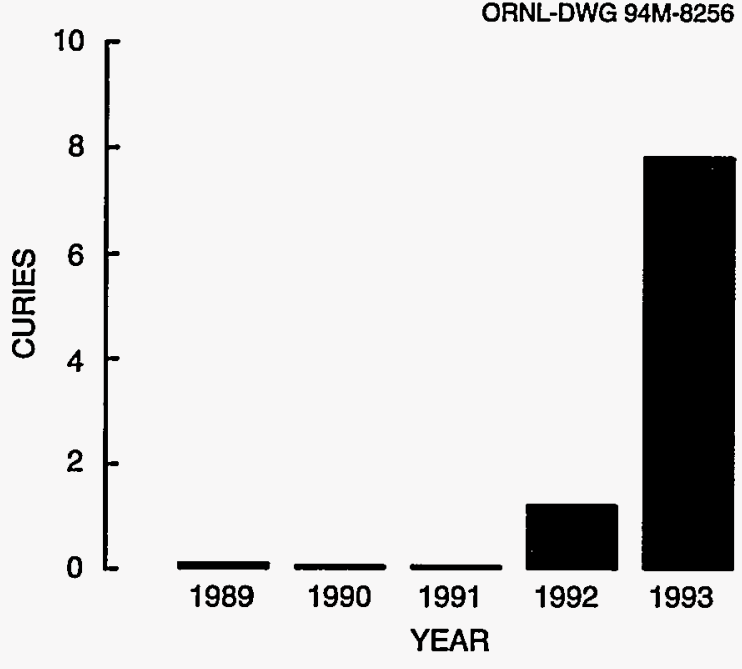

Fig. 4.3. Total curies of technetium discharged to air.

\section{Regulatory Requirements}

Discharges to the atmosphere are regulated under the Ohio Permit-To-Operate regulations. Under Ohio regulations, the Ohio Environmental Protection Agency (OEPA) can "register" small emission sources rather than issuing a formal permit. Permits to operate must be renewed every three years and set out explicit numerical limits on emission rates or operating restrictions and on monitoring and reporting requirements. A registration is valid until revoked by the OEPA and presumes that the registered source is too small to have a significant environmental impact. Most of the nonradiological sources at Portsmouth are either registered or are expected to be registered when the OEPA acts on them.

\section{Background}

Portsmouth operates numerous small sources of criteria (or conventional) air pellutants. The three most

significant are the coal-fired boilers at the X-600 steam plant, which supply the plant with 125 -psi steam for process and building heat. Typically, only one or two boilers operate at a time, depending on outside temperatures. The boilers have been issued permits by the OEPA specifying opacity, particulate, and sulfur dioxide $\left(\mathrm{SO}_{2}\right)$ limits as well as emission monitoring requirements. Emission monitoring results are reported quarterly to the OEPA.

Opacity and particulate emissions are controlled by electrostatic precipitators on each of the boilers. Opacity is a measure of the darkness of a plume of smoke and is measured by shining a beam of light through the smoke and measuring the percentage of light that passes through. Environmental regulations specify a limit of $20 \%$ opacity. Opacity is continuously measured (displayed digitally) and recorded on 24-hour circular charts. Portsmouth also has two "smoke readers" who are certified in accordance with USEPA Method 9 in the event the opacity monitors fail. Opacity is also used as a daily indicator of particulate emissions; this requires time-consuming, labor-intensive stack sampling to measure directly. Such stack sampling (and $100 \%$ compliance with particulate limitations) is required to renew the OEPA operating permits every three years.

Sulfur dioxide emissions are calculated from coal analyses rather than from direct measurement. All coal deliveries to the plant are sampled and analyzed for calorific value (British thermal units per pound), ash content, and sulfur content prior to burning. The quarterly reports to the OEPA summarize the amount of coal purchased, the average results of the coal analyses, and the calculated rate of $\mathrm{SO}_{2}$ emission as well as the opacity data.

In addition to the pollutants discussed previously, all fossil-fuel-burning equipment emits nitrogen oxides $\left(\mathrm{NO}_{x}\right)$ and carbon monoxide (CO). The primary source of $\mathrm{NO}_{x}$ and $\mathrm{CO}$ at Portsmouth is the steam plant itself. Also, minor contributions of these pollutants come from oil-fired heaters, stationary diesel engines, and mobile sources (e.g., automobiles).

Other air pollutants emitted from Portsmouth include chlorine, HF, methanol, assorted solvents, and coolants. The amounts of these chemicals emitted are estimated for annual reports to the USEPA as required under Section 313 of the Superfund Amendments and Reauthorization Act (SARA) and are incorporated in this report.

Portsmouth purchases liquid chlorine $\left(\mathrm{Cl}_{2}\right)$, which is used to disinfect incoming well water, outgoing treated sewage, and in-plant recirculating cooling water (RCW). Very little, if any, chlorine is lost to the air from the incoming water or the sewage, but RCW is effectively air-stripped of chlorine in the cooling towers. The chlorine is not emitted as elemental chlorine $\left(\mathrm{Cl}_{2}\right)$ but as hypochlorite $(\mathrm{HOCl})$, which is not considered hazardous.

Fluorine gas is used to condition process equipment and to recover deposits of uranium compounds deposited inside the cascade. Instead of shipping and storing large amounts of fluorine gas, Portsmouth purchases less dangerous $\mathrm{HF}$ in $850-\mathrm{lb}$ cylinders and converts it as needed to fluorine on-site. The fluorine reconverts to 
HF within the cascade. Hydrogen fluoride emissions from the cascade are directly monitored with the same continuous vent samplers used to monitor radionuclide emissions.

Methanol is used as a feed material for the $\mathrm{X}-700$ biodenitrification facility. The biodenitrification facility is a National Pollutant Discharge Elimination System (NPDES)-permitted wastewater treatment unit that uses bacteria to decompose waterborne nitrates into nitrogen gas before discharge to the X-6619 sewage treatment plant. Some methanol evaporates into the air.

Portsmouth formerly used fairly large quantities of halogenated solvents for degreasing metal parts. With the growing concern over depletion of the ozone layer, Portsmouth began looking for non-ozone-depleting substitutes. Substitute methods and materials were introduced beginning in 1992. Many degreasing operations now use aqueous solvents (i.e., soap solution, or nonchlorinated organic solvents). Two vapor degreasers have been decommissioned; one is being replaced by a steam booth, and one is simply being eliminated. Portsmouth still uses some 1,1,1-trichloroethane and Freon-113, both of which are recycled until they evaporate. Smaller amounts of other hydrocarbon solvents such as acetone and alcohol are also used and are assumed to evaporate completely. The nonhydrocarbon solvents used at Portsmouth-primarily nitric and citric acids in water-are not volatile enough to contribute significantly to air emissions.

The gaseous diffusion process generates a great amount of heat that must be removed by the plant cooling system. Because water is a nuclear moderator and is chemically reactive with $\mathrm{UF}_{6}$, it would be unsafe to cool the process directly with RCW, so Portsmouth uses a two-stage system using Freon-114 as the intermediate coolant. Inevitably, given the size of the cooling system, some Freon-114 leaks into the cascade, into the RCW, or into the air. A "thermal degrader" destroys Freon-114 that enters the cascade, but Freon-114 emissions from the RCW system and from building ventilation are difficult to control. Current estimates of total Freon-114 emissions are based on monthly inventories and include no allowance for Freon-114 destroyed in the cascade. A total of 156,400 kg of Freon-114 was released in 1993 (see Appendix C of this report, which contains chemical release data). Comparatively small amounts of other coolants, such as Freon-12, Freon-22, and ethylene glycol, are lost from plant air conditioners.

Another air pollutant present at Portsmouth is asbestos released by renovation or demolition of plant facilities. Asbestos emissions are not included under Section 313 of SARA, and no quantified emission level is available. Asbestos emissions are controlled by a system of work practices supervised by the Industrial Hygiene Department. The amount of asbestos removed and disposed of is reported quarterly to the OEPA.

\section{Results}

New opacity monitors were installed on all three boilers in early 1993. The OEPA certified all three monitors as meeting the performance criteria based on performance tests required by federal regulations. The monitors have worked flawlessly since installation.

The steam plant boilers operated a total of 1,008,035 minutes including startup and shutdown operations. Five opacity exceedences caused a total of 144 minutes above $20 \%$ opacity, and planned electrical outages added another 680 minutes for a total of 824 minutes of operation above $20 \%$ opacity. These exceedences amounted to $0.08 \%$ of the boiler operation time, and all are specifically exempted under Ohio regulations (Ohio Administrative Code 3745-17-07). A total of 4385 minutes was required for boiler startup and shutdown operations during the year, which is $0.44 \%$ of the operating time. Thus, during 1993 the steam plant operated below its $20 \%$ opacity limit $99.48 \%$ of the time, and all of the operation time above $20 \%$ was legally exempted.

The steam plant has an $\mathrm{SO}_{2}$ limit of $6.16 \mathrm{lb} / \mathrm{mm}$ Btu of heat input calculated on a monthly basis. This limit was not exceeded during 1993. Several truckloads of coal were above the limit; however, this coal was blended with lower sulfur coal prior to burning so that the $\mathrm{SO}_{2}$ limit was not exceeded at any time.

Applications for renewal of the operating permits for all three boilers were submitted in August 1993. Stack tests for emissions of total particulate matter, total particulate matter $10 \mu \mathrm{m}$ and less in diameter $\left(\mathrm{PM}_{10}\right), \mathrm{NO}_{\mathrm{x}}$, and CO were run on all three boilers in December 1993 as part of the permit renewal process. The OEPA has accepted the test results as valid and has begun processing the permit applications.

During 1993 the electrical power circuits feeding the steam plant were revamped to provide automatic switching from two substations on different main power transmission lines to provide for continuity of power in the event of a power failure on one transmission line. With prior permission from the OEPA, several total power outages were implemented at the steam plant for worker safety. On September 8, a 340-minute outage occurred.

\section{4-6 Effluent Monitoring}


Visual emission observations showed average opacities of $56 \%$ for boiler 1 and $32 \%$ for boiler 2 . On October 5 , a 10-minute outage occurred. Visual emission observations showed that boiler 2 remained within the opacity limit, while the opacity for the boiler 1 was $50 \%$ for 6 minutes and $26 \%$ for 6 minutes. On November 23, power was shut off for 220 minutes. Visual emission observations indicated that both boilers 2 and 3 remained within the $20 \%$ limit.

No mechanical malfunctions or opacity exceedences occurred during the first or second quarters of 1993. However, there were five opacity exceedences during the last two quarters, all caused by mechanical malfunctions. These exceedences were reported to the OEPA as required by regulations and are not considered violations. On August 6, the stokers on boiler 1 broke, causing the load to shift suddenly to boiler 2, which then exceeded the opacity limit for a total of 78 minutes. On September 7, an instrument mechanic was working on the steam plant pneumatic control system and disconnected an air line, causing the master controller to shut down. Boilers 1 and 2 sensed that as demand and began to feed coal at the maximum rate. Boiler 2 exceeded the opacity limit for 24 minutes, while boiler 1 remained within the limit. On December 1, a feed water pump overloaded the main power breaker to boiler 2 , shutting off power to the boiler; this resulted in an opacity of 95\% for 6 minutes. On December 24, a rotary vane hopper on boiler 1 became plugged. When the operator unplugged the hopper, opacity rose to 28,38 , and finally to $60 \%$ for a total of 18 minutes. On December 30 , the main power breaker on boiler 2 tripped again, causing an opacity exceedence for 18 minutes with successive 6-minute averages of 95,93 , and $44 \%$.

\section{LIQUID DISCHARGES}

This section briefly describes major water discharge sources and associated control and monitoring systems at Portsmouth. A summary of total annual radiological and nonradiological discharges and a discussion of the significance of the data and of any anomalies follow.

Existing Portsmouth collection and treatment facilities are discussed in this section together with facility improvements, new treatment facilities, and studies to improve performance. Varieties of hazardous liquid wastes-uranium contaminated as well as noricontaminated-result from operations associated with RCW, uranium recovery, and decontamination activities. In addition, various conventional wastes exist such as domestic sewage, steam plant wastewater, coal-pile runoff, and once-through cooling water. Major wastewater sources and systems are shown in Fig. 4.4.

\section{Background}

The quality of surface waters on the Portsmouth site is affected by wastewater discharges and groundwater transport of contaminants from land disposal of waste. Although bedrock characteristics differ somewhat among the watersheds of these surface waters, the observed differences in water chemistry are attributed to different contaminant loadings rather than geologic variation. Water quality, radioactivity, and flow measurements are made at a number of stations operated by Portsmouth. Water samples were collected and analyzed at various intervals (weekly, monthly, etc.) for radiological and nonradiological parameters.

Liquid plant effluents are regulated by the NPDES permit and either discharge to surface streams that pass through the reservation to the Scioto River or are piped directly to the Scioto River. A brief description of these discharge points, or outfalls, is provided in the following paragraphs. The locations of the NPDES-permitted outfalls are shown in Fig. 4.5.

NPDES 001 (X-230J-7 holding pond)-The X-230J-7 holding pond provides a quiescent zone for settling of suspended solids, dissipation of chlorine, and oil diversion and containment. A flow diagram for outfall 001 is shown in Fig. 4.6.

NPDES 609 (X-624 carbon filtration facility) - This facility provides for removal of volatile organic compounds (VOCs) from contaminated groundwater originating from the X-701B plume interceptor trenches. These groundwater interceptor trenches were constructed to control the migration of VOC-contaminated groundwater toward Little Beaver Creek. Discharge of treated water is to the X-230J-7 holding pond (NPDES outfall 001). 
ORNL-DWG 87M-8966R2

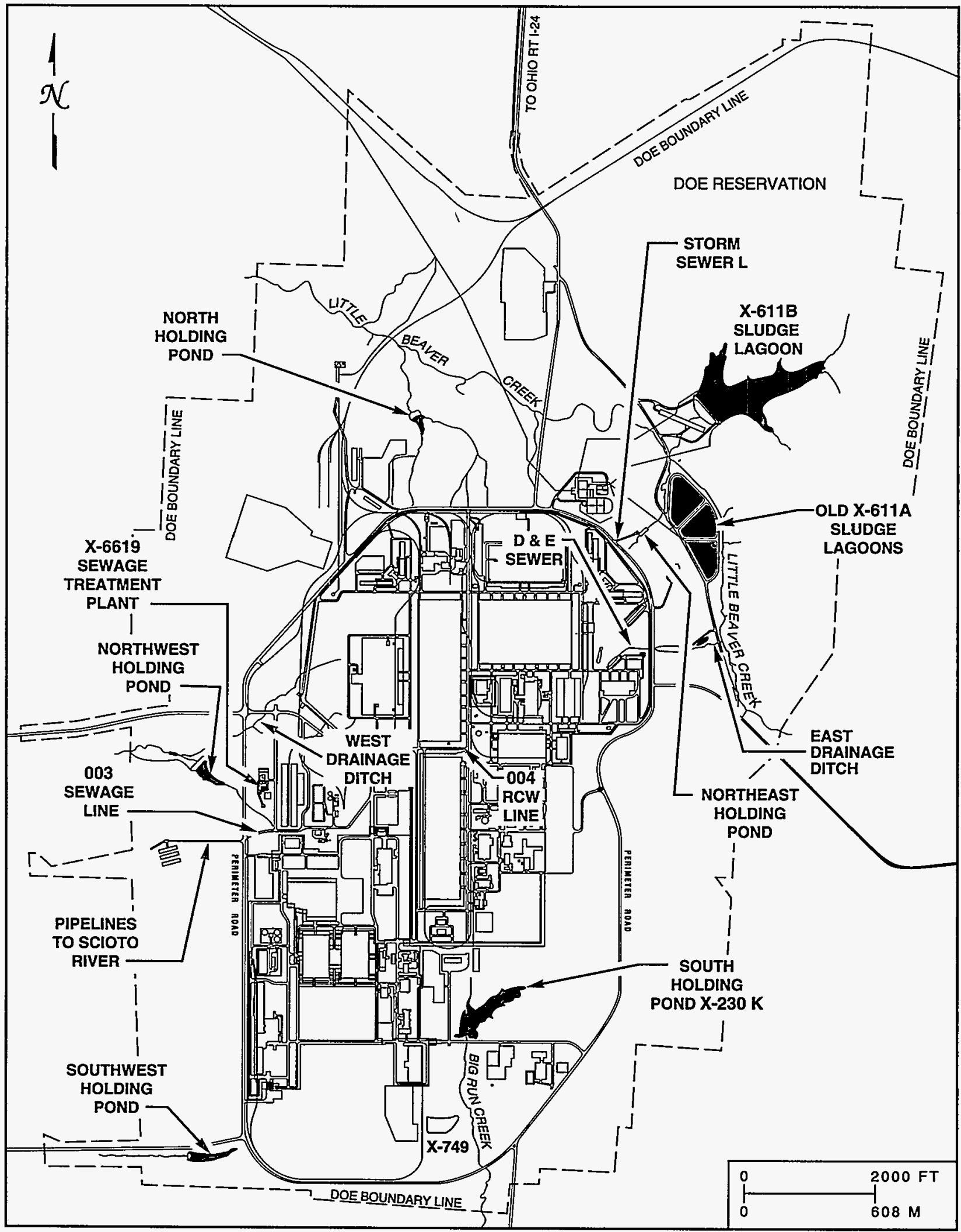

Fig. 4.4. Major wastewater sources and systems at Portsmouth. 
ORNL-DWG 87M-6714R4

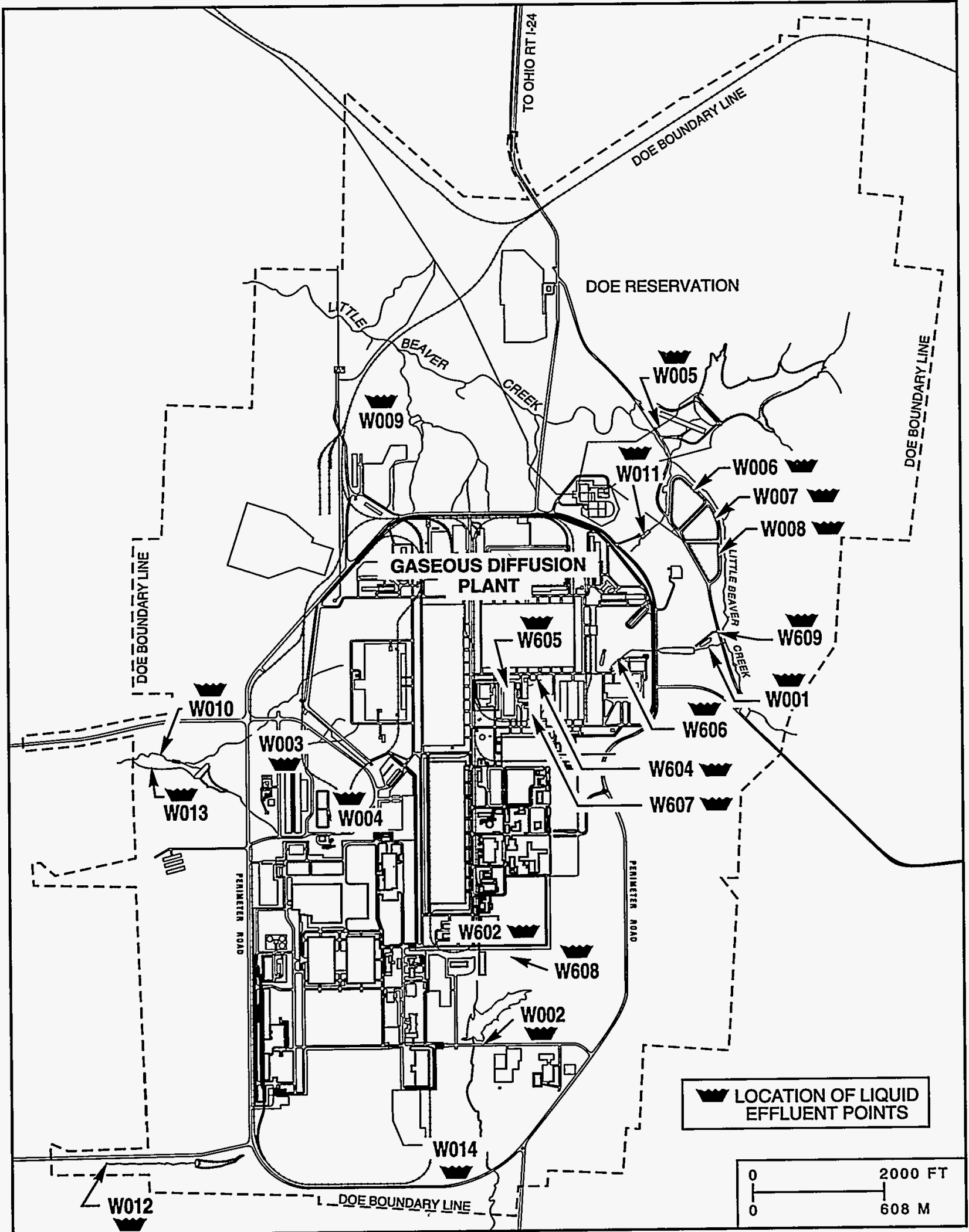

Fig. 4.5. NPDES water sampling locations at Portsmouth. 


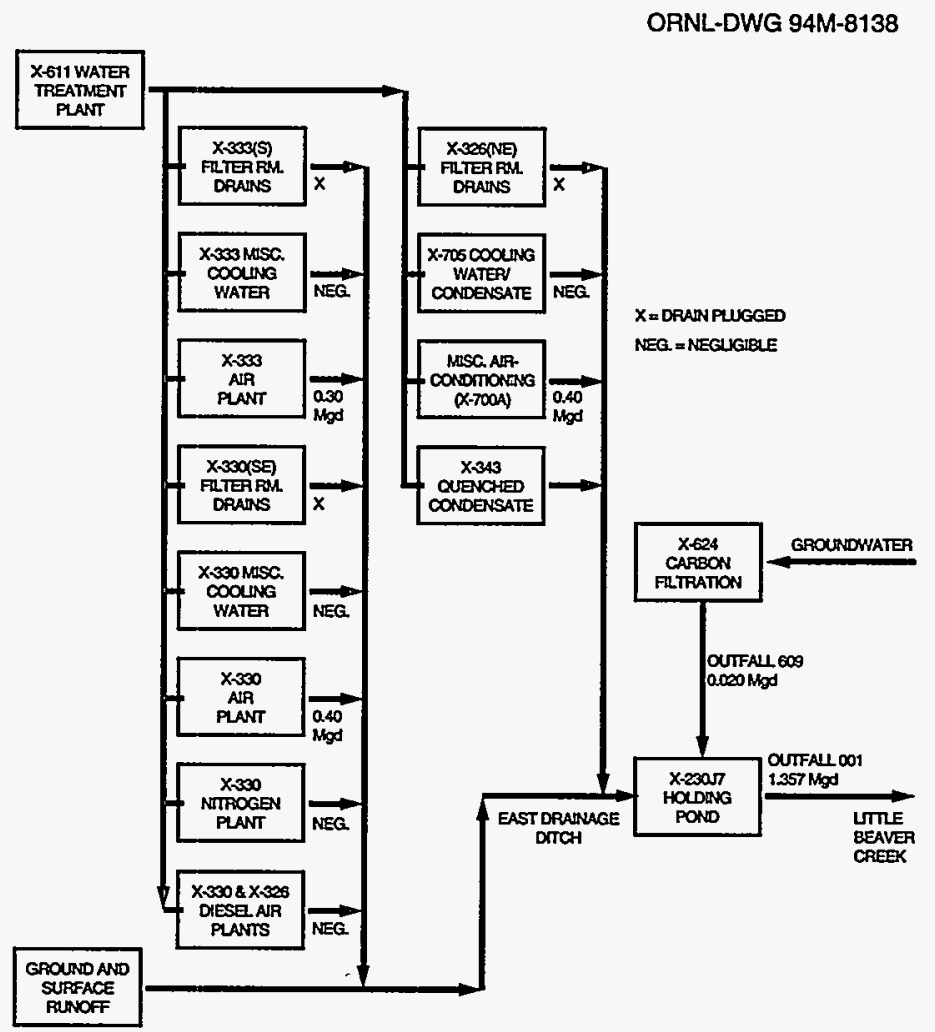

Fig. 4.6. Flow diagram for outfall 001 (X-230J-7 east holding pond).

NPDES 002 (X-230K south holding pond)-The X-230K south holding pond provides a quiescent zone for settling of suspended solids, dissipation of chlorine, and $\mathrm{pH}$ adjustment prior to discharge. A flow diagram for outfall 002 is shown in Fig. 4.7.

NPDES 602 (X-621 coal-pile treatment plant)-This plant provides a lagoon for collecting and equalizing coal-pile runoff and steam plant cooling water. The collected water is $\mathrm{pH}$ adjusted, and suspended solids are removed using a lamella settler. Sludge is dewatered using a pressure filter. Other steam plant waste streams that originally were sent to the $\mathrm{X}-621$ facility are now treated separately and are sent directly to the south holding pond. These waste streams include (1) water-softening regeneration water, which is $\mathrm{pH}$ adjusted; (2) ash wash water, which has solids removed using a pressure filter; and (3) steam plant boiler blowdown water, which is sent untreated to the south holding pond. A flow diagram for outfall 602 is shown in Fig. 4.7.

NPDES 003 (X-6619 sewage treatment plant)-This plant treats plant sewage and pretreated process wastewaters by the activated sludge process, similar to a modern municipal sewage treatment plant. Excess sludge from the system is dried and then containerized. A flow diagram for outfall 003 is shown in Fig. 4.8.

NPDES 604 (X-700 biodenitrification plant)-The biodenitrification plant reduces nitrates in process wastewater to nitrogen gas. Raffinate (generated from uranium recovery operations) is treated with a pressure filter to remove heavy metals, and technetium is removed by ion exchange prior to biodenitrification. The high-nitrate solution remaining from these operations is diluted and treated biologically using a fluidized-bed coal media reactor. Bacteria and minor coal fines are discharged to the X-6619 sewage treatment plant. A flow diagram for outfall 604 is shown in Fig. 4.8.

NPDES 605 (X-705 waste treatment facility)-In November 1988, the X-701B holding pond (NPDES 601) was eliminated and replaced with the new X-705 waste treatment facility to treat X-705 wastewater. Process wastewaters are collected, stored, treated for oil and grease, and then further treated using microfiltration and pressure filtration technology. Discharges are released to the RCW blowdown line, which ultimately discharges to the X-616 chromate treatment facility (NPDES 004) and to the Scioto River. On April 9, 1992, discharge from outfall 605 was rerouted to the X-6619 sewage treatment plant (outfall 003). A flow diagram for outfall 605 is shown in Fig. 4.8. 


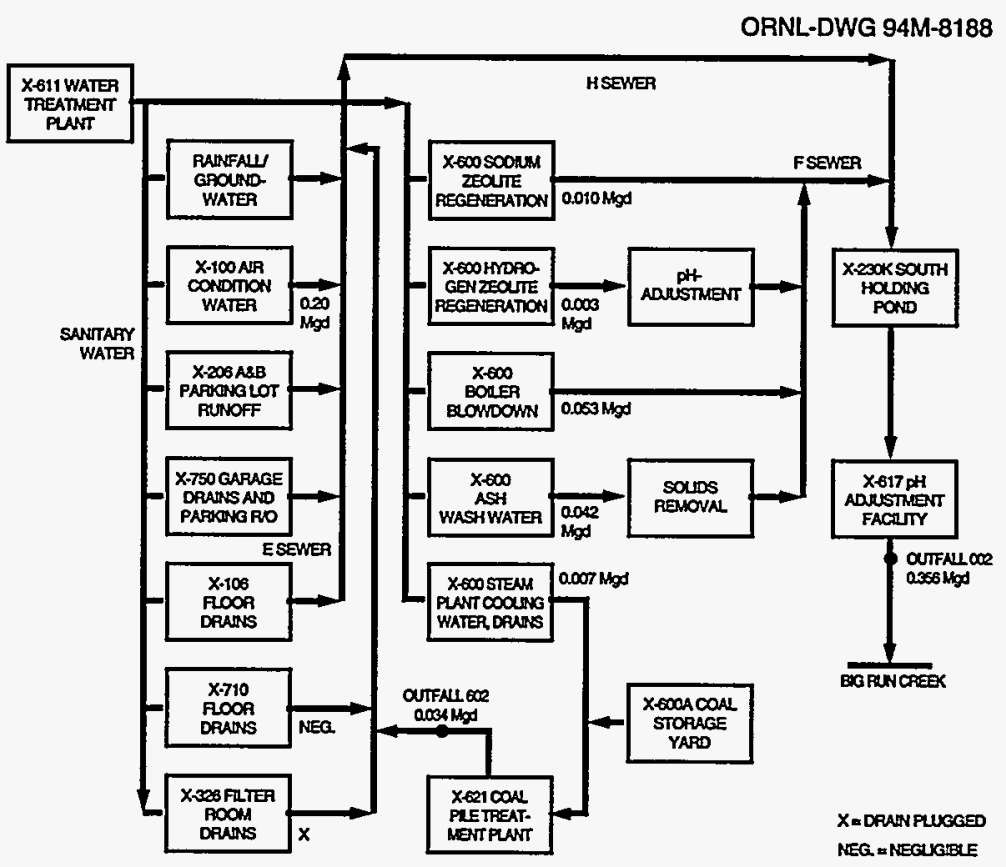

Fig. 4.7. Flow diagram for outfalls 002 and 602 (X-230K south holding pond and $X-621$ coal-pile treatment plant).

NPDES 606 (X-701B carbon filtration facility)-This facility provides for removal of VOCs from contaminated groundwater originating from X-701B site remediation activities from miscellaneous well development and purge waters. Treated water is discharged to the sanitary sewer and then to outfall 003.

NPDES 607 (X-700 air stripper)-The X-700 air stripper was constructed to remove VOCs from contaminated groundwater originating from the X-701B site remediation activities. Discharge of treated water is to the sanitary sewer and then to outfall 003 . This facility operates infrequently because of stringent air discharge limitations and improved VOC removal capabilities now available at the X-701B carbon filtration facility.

NPDES 608 (X-622 carbon filtration facility)-This facility provides for removal of VOCs from contaminated groundwater originating from $X-231 B$ and $X-749$ site remediation activities and from X-705 sump water.

NPDES 004 (X-616 chromate treatment facility)—This facility was originally used to remove chromatebased corrosion inhibitors from RCW blowdown prior to discharge to the Scioto River. Portsmouth has since converted its RCW system to a nontoxic, phosphate-based corrosion inhibitor, and on April 19, 1992, X-616 was taken out of operation except as a pumping station. A flow diagram for outfall 004 is shown in Fig. 4.9.

NPDES 005 (X-611B sludge lagoon)—The X-611B sludge lagoon provides a quiescent zone for settling lime sludge used in the water-softening process. X-611B also receives some water from rainfall runoff; supernatant is returned to the water treatment plant. Discharges are rare and occur only during periods of excessive rainfall. A flow diagram for outfall 005 is shown in Fig. 4.10.

NPDES 006 (X-611A north sludge lagoon), NPDES 007 (X-611A middle sludge lagoon), and NPDES 008 $(X-611$ A south sludge lagoon)-These lagoons once received lime sludge from the plant water-softening process and are filled to capacity. The lagoons now receive water from rainfall. Discharges from these facilities are rare and occur only during periods of excessive rainfall. Flow diagrams for outfalls 006,007 , and 008 are shown in Fig. 4.10.

NPDES 009 (X-230L north holding pond)—The north holding pond provides a quiescent zone for settling of suspended solids and dissipation of chlorine. The pond can be closed for emergency containment of unpermitted discharges. A flow diagram for outfall 009 is shown in Fig. 4.11. 
ORNL-DWG 94M-8189

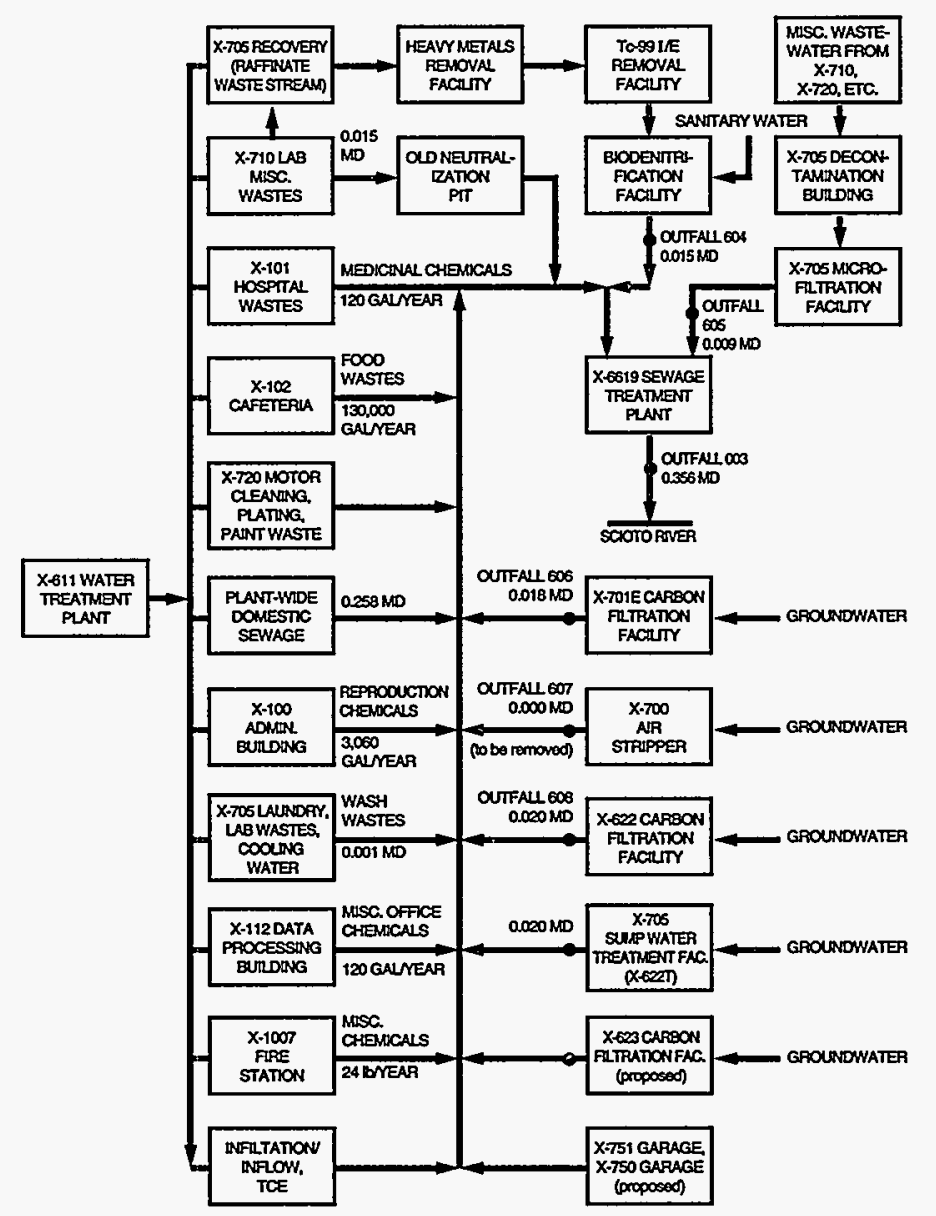

Fig. 4.8. Flow diagram for outfalls 003, 604, and 605 (X-6619 sewage treatment plant, $X-700$ biodenitrification plant, and $X-705$ waste treatment facility).

NPDES 010 (X-230J-5 northwest holding pond)-The X-230J-5 holding pond provides a quiescent zone for settling suspended solids, dissipation of chlorine, and oil diversion and containment. A flow diagram for outfall 010 is shown in Fig. 4.12.

NPDES 011 (X-230J-6 northeast holding pond)-The X-230J-6 holding pond provides a quiescent zone for settling of suspended solids, dissipation of chlorine, and oil diversion and containment. A flow diagram for outfall 011 is shown in Fig. 4.13.

NPDES 012 [X-2230M holding pond, formerly Gas Centrifuge Enrichment Plant (GCEP) 001]-The $\mathrm{X}-2230 \mathrm{M}$ holding pond provides a quiescent zone for settling of suspended solids, dissipation of chlorine, and containment of oil with effluent baffling. This outfall was renamed outfall 012 by the OEPA on September 23, 1991.

NPDES 013 (X-2230N holding pond, formerly GCEP 002)-The X-2230N holding pond provides a quiescent zone for settling of suspended solids, dissipation of chlorine, and containment of oil with effluent baffling. This outfall was renamed outfall 013 by the OEPA on September 23, 1991.

NPDES 014 (holding pond not constructed, formerly GCEP 003)—A holding pond originally planned and - designated as outfall 003 was not constructed because of significant changes in area topography. The Ports NPDES permit issued September 23, 1991, limits discharges to this outfall to storm water only and requires no routine monitoring. This outfall was renamed outfall 014 by the OEPA on September 23, 1991.

A flow diagram for NPDES outfalls 012, 013, and 014 is shown in Fig. 4.14. 


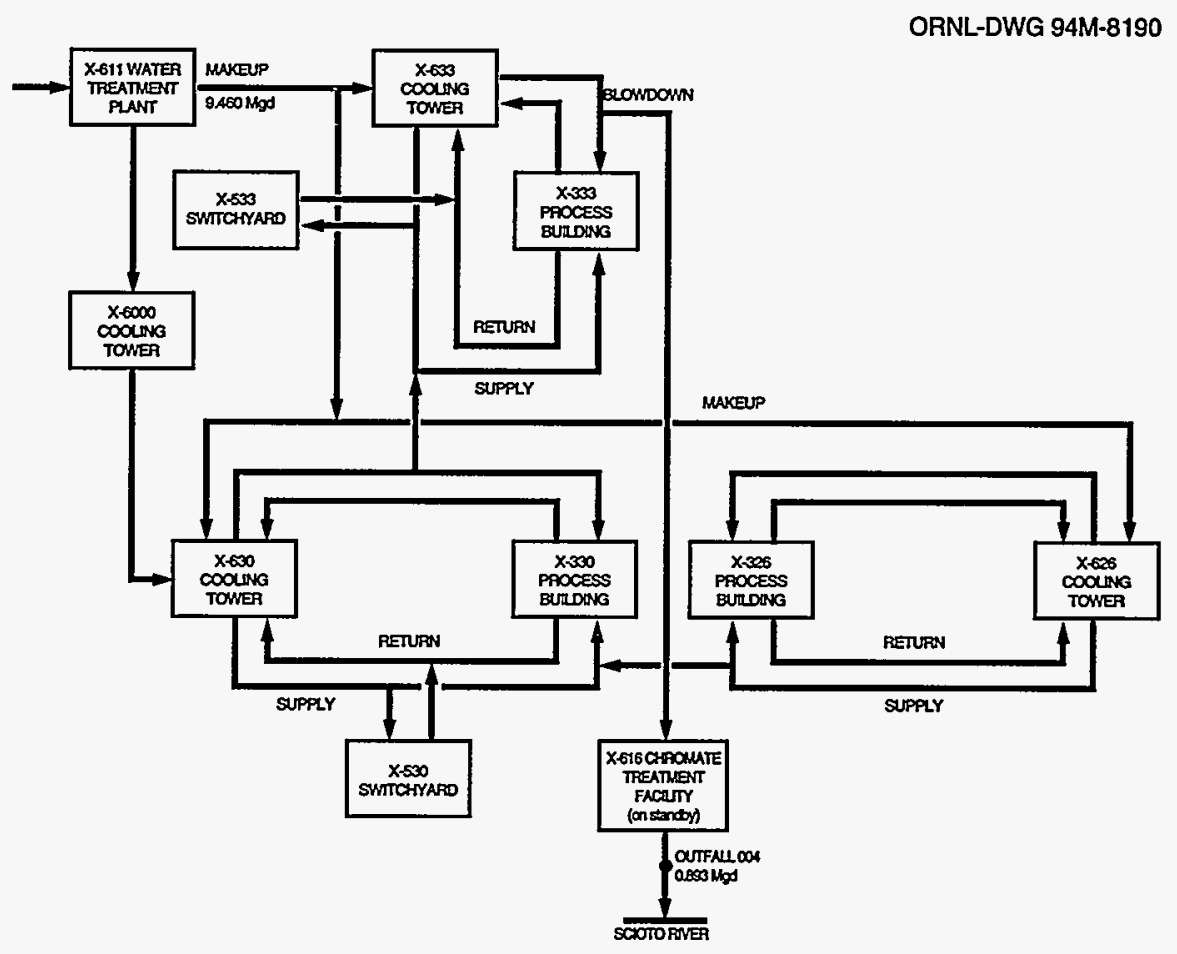

Fig. 4.9. Flow diagram for outfall 004 (X-616 chromate treatment facility and RCW system).

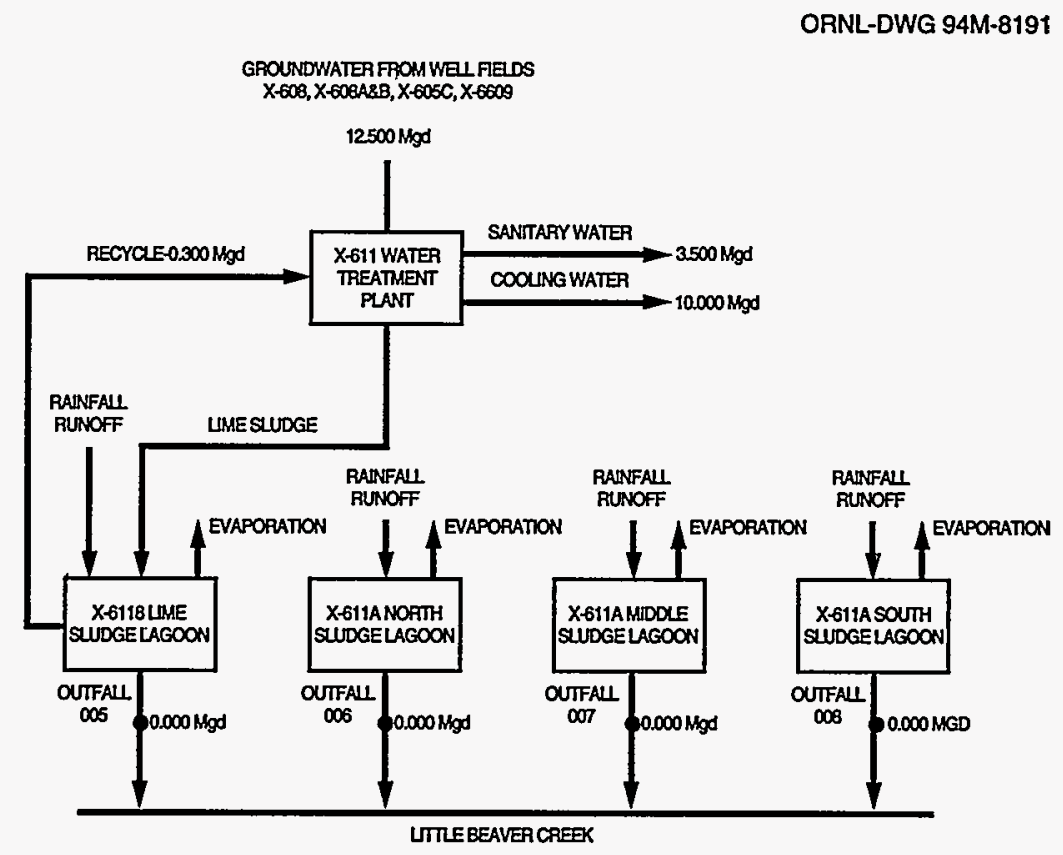

Fig. 4.10. Flow diagram for outfalls $005,006,007$, and 008 (X-611B sludge lagoon and $X-611 A$ north, middle, and south sludge lagoons). 
ORNL-DWG 94M-8193

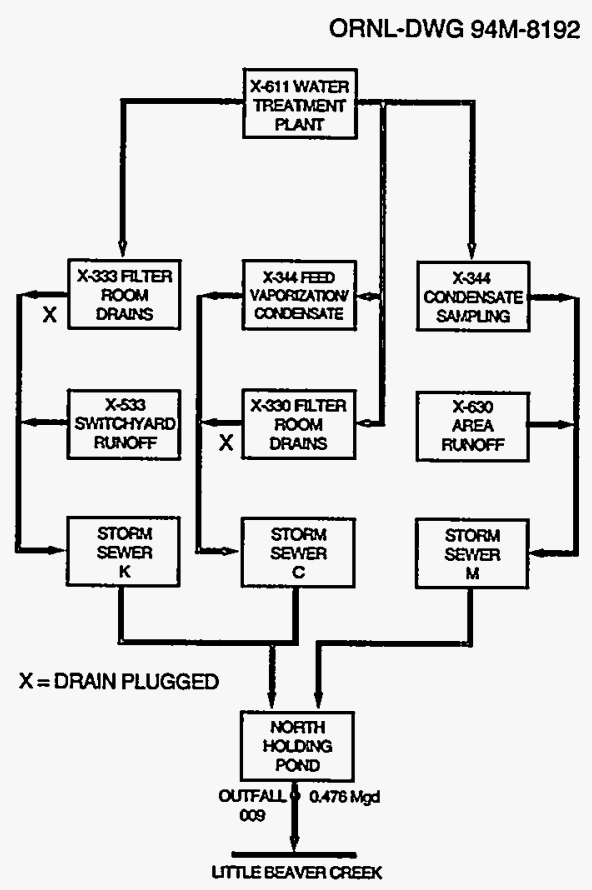

Fig. 4.11. Flow diagram for outfall 009 (X-230L north holding pond).

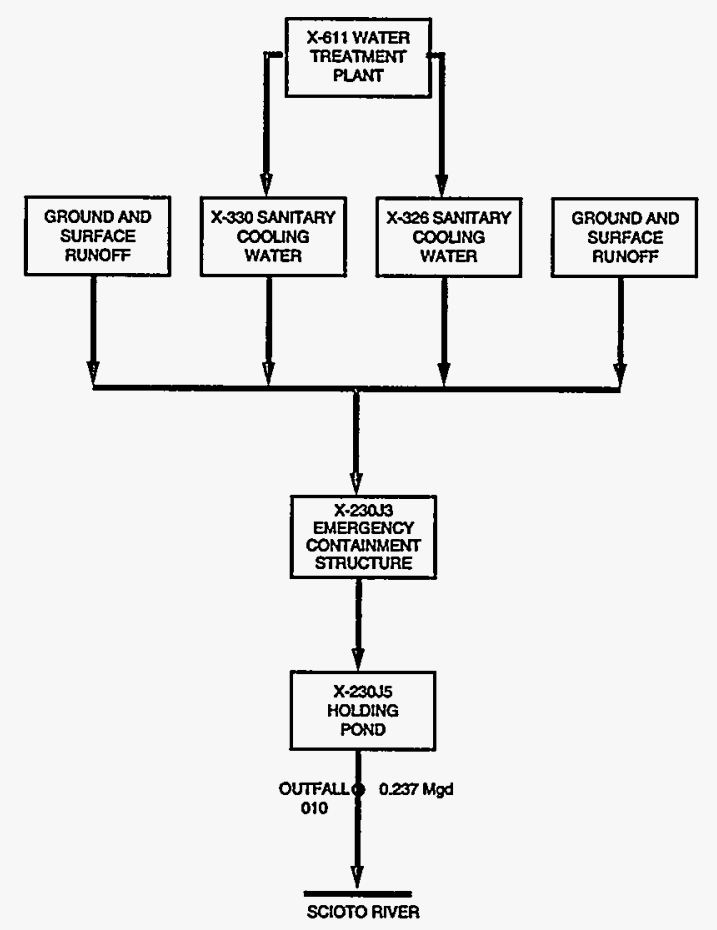

Fig. 4.12. Flow diagram for outfall 010 (X-230J-5 northwest holding pond).

\section{Radiological Liquid Discharges}

Virtually all radiological liquid discharges from Portsmouth come from decontamination and cleaning activities. (The exceptions are trace concentrations of naturally occurring uranium in storm water runoff.) Currently, all decontamination and cleaning wastewaters are discharged through the X-6619 sewage treatment plant (outfall 003). Until 1988, most of these wastewaters were treated in the X-701B facility, which discharged to the X-230J-7 holding pond (outfall 001). Residual uranium from the X-701B discharges then partially settled out in the X-230J-7 facility. As a result, outfalls 003 and 001 are the primary radiological discharge points at Portsmouth.

\section{Regulatory Requirements}

DOE regulates radionuclide emissions to all environmental media through DOE orders 5400.1, General Environmental Protection Program, and 5400.5, Radiation Protection of the Public and the Environment. DOE Order 5400.5 sets an annual dose limit of $100 \mathrm{mrem} / \mathrm{year}$ to any member of the public from all radionuclide releases.

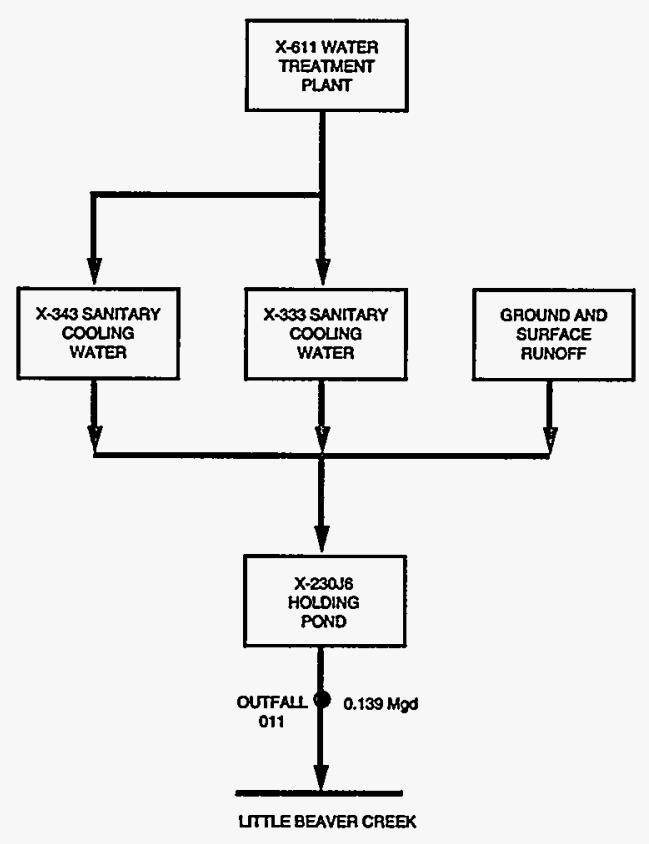

Fig. 4.13. Flow diagram for outfall 011 (X-230J-6 northeast holding pond). 


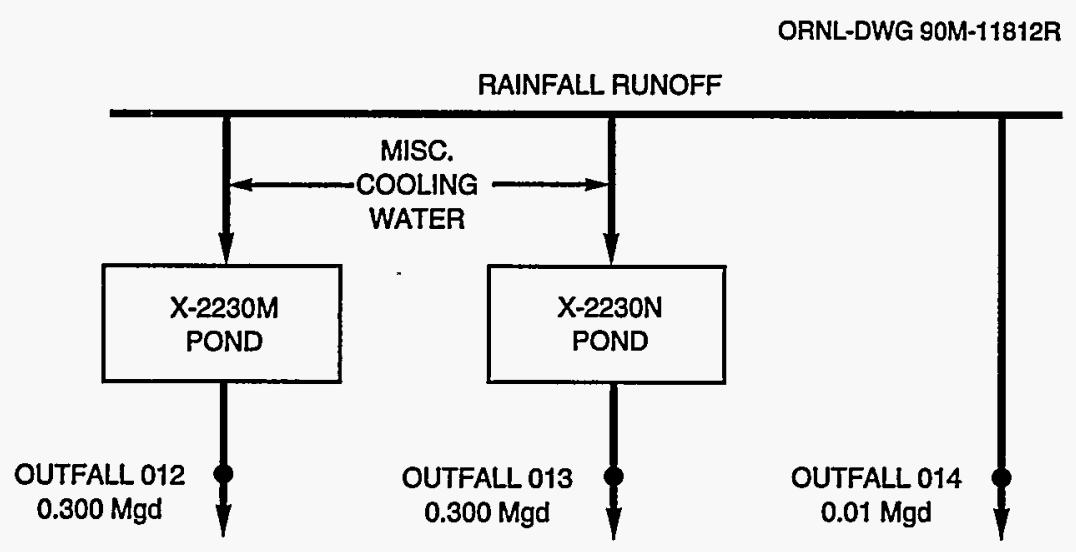

Fig. 4.14. Flow diagram for outfalls 012 and 013 (X-2230M holding pond and $X-2230 \mathrm{~N}$ holding pond) and the drainage sector designated as outfall 014.

daughters ${ }^{231} \mathrm{Th},{ }^{234} \mathrm{Th}$, and ${ }^{234 m} \mathrm{~Pa}$ are presumed to be present in equilibrium with their parent nuclides based on the laws of physics.

\section{Results}

Liquid radiological discharges from Portsmouth (see Table 4.2) had no significant impact on public health or the environment. Total radionuclide discharges from Portsmouth increased somewhat in 1993 because of increased levels of technetium resulting from decontamination activities. Mass and activity emissions of uranium decreased (from 37 to $27 \mathrm{~kg}$ and from 0.17 to $0.12 \mathrm{Ci}$ ), but technetium discharges increased from 0.21 to $0.58 \mathrm{Ci}$. This is approximately equal to the average annual discharge of ${ }^{99} \mathrm{Tc}$ over the previous four years. Discharges of uranium daughters remained essentially unchanged. No unplanned releases to surface water occurred during 1993.

Table 4.2. Portsmouth radionuclide releases to surface water in 1993

\begin{tabular}{lll}
\hline \multicolumn{1}{r}{ Radionuclide } & \multicolumn{1}{c}{$\mathrm{kg} /$ year } & $\mathrm{Ci} /$ year \\
\hline${ }^{234} \mathrm{U}$ & 0.017 & 0.11 \\
${ }^{235} \mathrm{U}$ & 1.6 & 0.0034 \\
${ }^{236} \mathrm{U}$ & 0.00048 & 0.000030 \\
${ }^{238} \mathrm{U}$ & 25.2 & 0.0084 \\
Total uranium & 26.8 & 0.12 \\
${ }^{99} \mathrm{Tc}$ & 0.034 & 0.58 \\
Uranium daughters & $3.7 \times 10^{-10^{9}}$ & 0.020 \\
\hline \multicolumn{2}{c}{0}
\end{tabular}

Despite the increase in ${ }^{99} \mathrm{Tc}$, Portsmouth discharges remained well below the applicable DOE standard (100 mrem/year) and far below the levels listed as safe by national and international regulatory bodies such as the Occupational Safety and Health Administration, the Nuclear Regulatory Commission, and the International Committee on Radiation Protection (5 rem/year). Figures 4.15 through 4.18 show the five-year trends for uranium (in curies and kilograms of uranium), ${ }^{99} \mathrm{Tc}$, and uranium daughters discharged to surface waters through NPDES outfalls. 


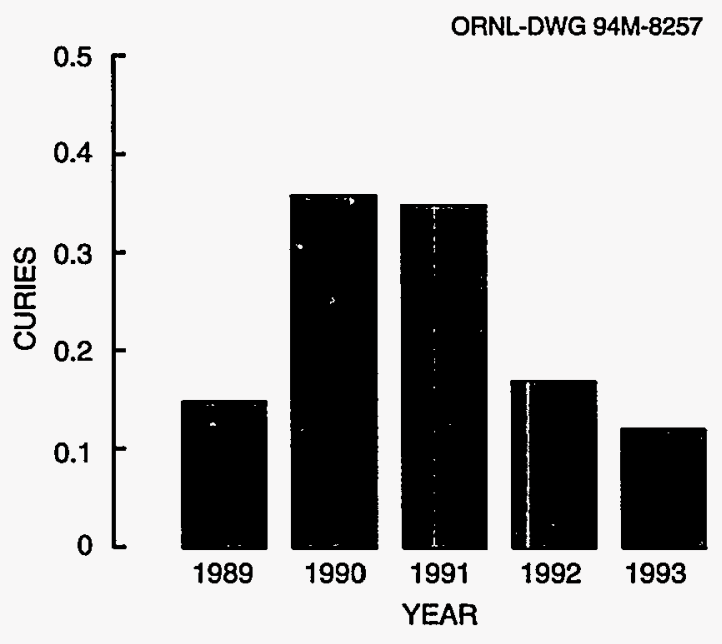

Fig. 4.15. Total curies of uranium discharged to surface water.

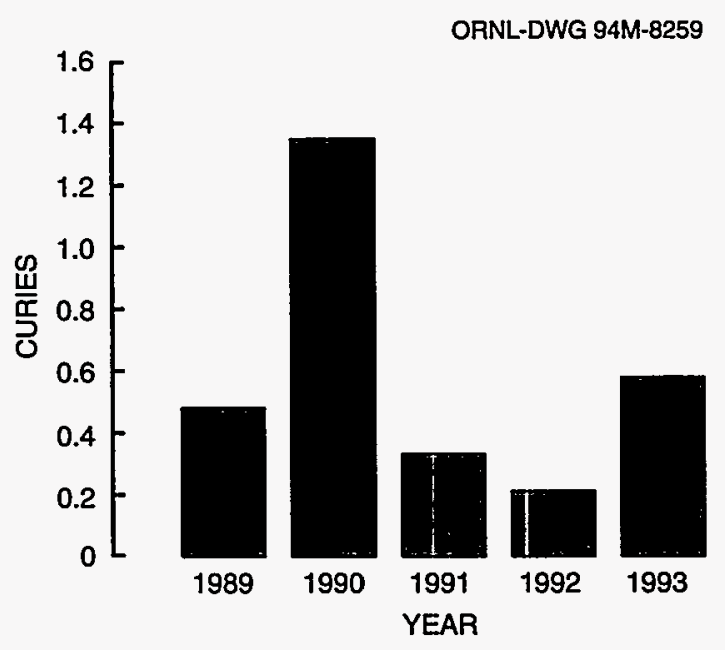

Fig. 4.17. Total curies of technetium discharged to surface water.

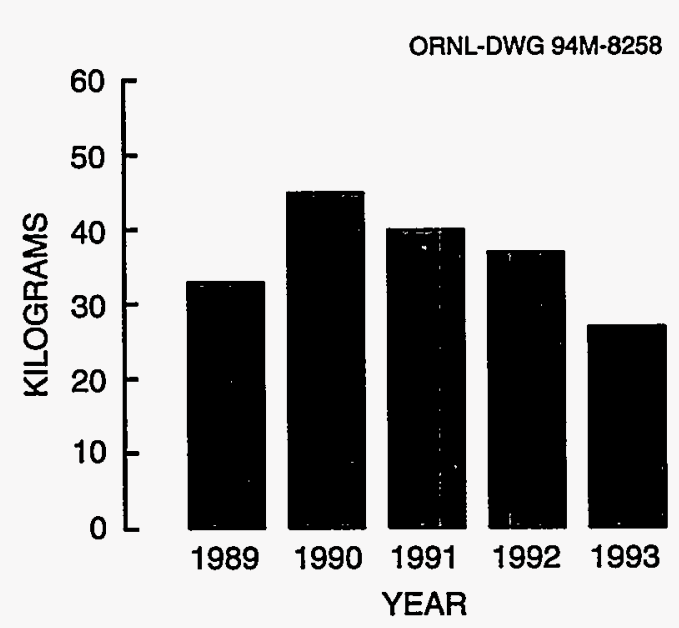

Fig. 4.16. Total kilograms of uranium discharged to surface water.

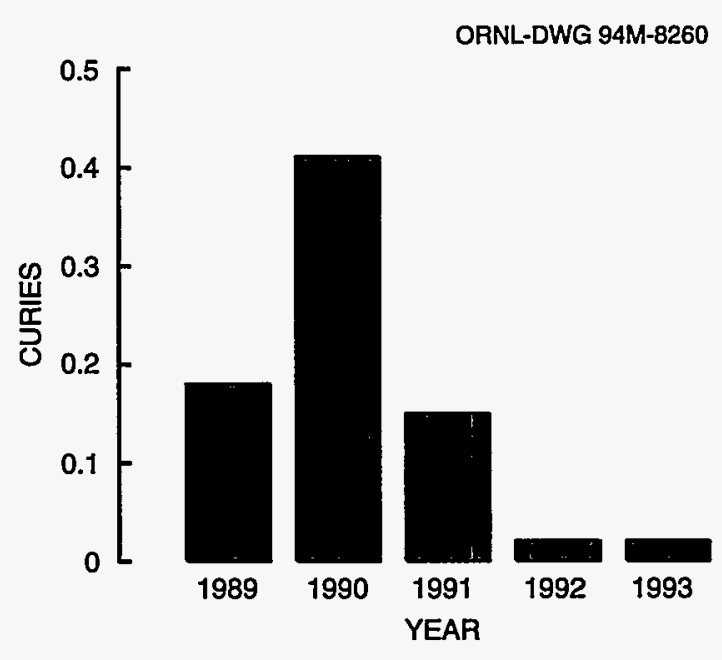

Fig. 4.18. Total curies of uranium daughters $\left({ }^{231} \mathrm{Th}\right.$, ${ }^{234} \mathrm{Th}$, and $\left.{ }^{234 \mathrm{~m}} \mathrm{~Pa}\right)$ discharged to surface water.

As shown in Table 4.2 and Fig. 4.15, a total of $0.12 \mathrm{Ci}$ of uranium was discharged in 1993. This was equivalent to $27 \mathrm{~kg}$ of uranium (Fig. 4.16). Almost half of the uranium-47\%-was discharged through outfall 003 to the Scioto River, and another $32 \%$ was discharged though outfall 001 . All other outfalls contributed between 1 and $6 \%$ of the total. Note that most of the gross alpha concentrations listed for these other outfalls (and fully half of the concentrations listed for outfall 001) are actually below the limit of detection. Consequently, uranium discharges from these outfalls are actually lower than reported.

As shown in Table 4.2 and Fig. 4.17, a total of $0.58 \mathrm{Ci}$ of technetium was discharged in 1993; this value is consistent with average technetium releases over the past four years. Of the total technetium released, $80 \%$ was discharged through outfall 003 to the Scioto River, 9\% through outfall 001 to Little Beaver Creek, and 4\% through outfall 004 to the Scioto River. 
As shown in Table 4.2 and Fig. 4.18, a total of $0.02 \mathrm{Ci}$ of uranium daughter products was discharged in 1993. Uranium daughter products are generated by the natural radioactive decay of uranium and therefore roughly follow uranium emissions. Because ${ }^{238} \mathrm{U}$ generates the bulk of the detectable uranium daughters, the proportion of uranium daughter products to total uranium will vary with the uranium assay. The uranium daughters make no significant contribution to the radiation dose to the public.

\section{Nonradiological Liquid Discharges}

Portsmouth operations also release various nonradiological substances to surface waters. In addition, a shallow groundwater aquifer under Portsmouth discharges to local surface waters on all four sides of the plant, although not always within the reservation boundary.

\section{Regulatory Requirements}

Nonradiological discharges to surface waters are regulated by the Portsmouth NPDES permit issued under the authority of the Clean Water Act. The OEPA has regulatory authority for the Clean Water Act at Portsmouth; however, the OEPA did not become active in administering NPDES permits to federal facilities until early 1983. In a letter dated May 25, 1983, from the OEPA, Portsmouth was advised to begin sending monthly self-monitoring NPDES reports directly to the OEPA beginning with the August 1983 report. The most recent revision of the Portsmouth NPDES permit was issued on September 23, 1991, and additional modifications were issued on December 12, 1991; this permit stayed in effect throughout 1993, and Portsmouth conducted effluent-stream sampling in accordance with the NPDES permit.

\section{Sample Collection and Analytical Procedure}

The majority of nonradioactive constituents are regulated under the Portsmouth NPDES permit. Analysis is in accordance with Title 40, Code of Federal Regulations, Part 136 (40 CFR 136).

\section{Results}

The site-wide NPDES compliance rate for 1993 was $99.4 \%$. Compliance rates for individual parameters ranged from a low of $88 \%$ to a high of $100 \%$.

At the east drainage ditch (NPDES 001), compliance was high for all parameters. Two exceedences for total residual chlorine resulted in $93 \%$ compliance. Compliance with oil and grease and trichloroethylene were each $100 \%$. One high total suspended solids measurement caused by heavy rainfall runoff and embankment slippage resulted in $96 \%$ compliance. One high $\mathrm{pH}$ exceedence caused by algae and a malfunctioning high-level alarm resulted in $98 \%$ compliance. High ambient temperatures during the transition period from summer to winter months and the high usage of once-through cooling water resulted in three exceedences and a $92 \%$ compliance for temperature. Modifications in the use of cooling-water systems have helped in abating this problem.

The 1993 percentage of compliance was $100 \%$ for trichloroethylene at the X-624 carbon filtration facility (NPDES outfall 609).

At the X-230K south holding pond (NPDES 002), compliance rates remained high for all parameters. Compliance was $100 \%$ for total suspended solids, oil and grease, and $\mathrm{pH}$ in CY 1993. One high-temperature exceedence, caused by high ambient temperature, resulted in $98 \%$ compliance.

At the X-621 coal-pile treatment plant (NPDES 602), compliance rates were $100 \%$ for all parameters except $\mathrm{pH}$. A malfunctioning valve resulted in one low $\mathrm{pH}$ exceedence ( $98 \%$ compliance).

At the X-6619 sewage treatment plant (NPDES 003), compliance rates remained high for all parameters. Three exceedences for total suspended solids, caused by an operational upset, resulted in $94 \%$ compliance. Three total residual chlorine exceedences, caused by severe flow fluctuations, resulted in $98 \%$ compliance.

At the biodenitrification facility (NPDES 604), the X-705 microfiltration facility (NPDES 605), and the $\mathrm{X}-622$ carbon filtration facility (NPDES 608), the compliance rate for all parameters was $100 \%$.

At the X-701E carbon filtration facility (NPDES 606), the compliance rate for dichloroethylene was $100 \%$, but one exceedence for trichloroethylene reduced that compliance rate to $88 \%$. 
At the X-616 chromate treatment facility (NPDES 004), compliance was $100 \%$ for all parameters except total iron. One exceedence caused by a temporary RCW treatment program resulted in $96 \%$ compliance. Percentage rates for compliance are not presented for NPDES outfalls 005, 006, 007, 008, 609A, and 014 because effluent flows at these outfalls were infrequent and compliance percentage rates are not meaningful.

At the north holding pond (NPDES 009), compliance was $100 \%$ for all parameters.

At the west drainage ditch (NPDES 010), compliance was $100 \%$ for all parameters.

At the northeast drainage ditch (NPDES 011), compliance remained high for all parameters. One total suspended solids exceedence, caused by rainfall runoff, resulted in $92 \%$ compliance.

At NPDES 012 and NPDES 013 (formerly GCEPs 001 and 002), compliance was high for all parameters. At outfall 012, heavy rainfall runoff was responsible for one total suspended solids exceedence and resulted in $96 \%$ compliance. At outfall 013 , heavy rainfall runoff was responsible for two total suspended solids exceedences and resulted in $92 \%$ compliance.

In addition to the specific parameter percentage compliances shown, several unpermitted discharges occurred at the Portsmouth facility, affecting several NPDES outfalls and receiving streams. Six unpermitted discharges occurred during CY 1993. These discharges were caused by faulty equipment, accidental spills, abandoned landfill seeps, and fire water line ruptures. Investigations and corrective actions to prevent such discharges are in progress. 


\title{
5. Environmental Surveillance
}

\begin{abstract}
Environmental surveillance at Portsmouth Gaseous Diffusion Plant is conducted to assess the impact of plant operations on the surrounding environment. Surveillance includes direct monitoring of gamma radiation levels, air, surface water, groundwater, drinking water, creek and river sediments, soil, vegetation, food crops, and tish. Samples are analyzed for radiological contaminants as well potentially harmful nonradiological pollutants. Monitoring is conducted within the plant boundaries, on or near the property line, and up to $16 \mathrm{~km}$ (10 miles) from the plant site. Results for 1993 indicate that Portsmouth operations did not have a significant environmental impact outside the reservation boundaries.
\end{abstract}

\section{INTRODUCTION}

Portsmouth Gaseous Diffusion Plant (Portsmouth) has maintained an environmental surveillance network since 1964. Environmental surveillance involves monitoring and sampling the surrounding environment, as distinct from the more common monitoring of effluents. Both programs provide distinct advantages. Effluent monitoring allows the sources of the effluents to be identified and controlled, thus minimizing environmental impacts. However, effluent monitoring cannot be used to reliably quantify an environmental impact but can only be used to drive a model that tries to predict the nature and extent of the associated impacts. Consequently, an environmental surveillance program is necessary both to validate environmental models and to verify that no unexpected impacts are occurring.

\section{Applicable Regulations}

U.S. Department of Energy (DOE) Order 5400.1, General Environmental Protection Program, requires DOE facilities to establish, in addition to effluent monitoring programs, environmental surveillance programs sufficient to ensure that no unrecognized environmental impact is occurring as a result of DOE operations. The details of the Portsmouth. Environmental Monitoring Program are documented in the Environmental Monitoring Plan for the Portsmouth Gaseous Diffusion Plant (MMES 1994), which is discussed in detail in Section 2, "Environmental Compliance."

\section{EXTERNAL GAMMA RADIATION}

External gamma radiation measurements confirm that direct radiation and radioactive effluents from Portsmouth are not significantly different from natural background levels. This section describes the external gamma radiation monitoring network at Portsmouth and presents a summary of the data collected by that network. A brief summary of the radiation doses that can be estimated from these data is also presented. A more extensive discussion of radiation dose calculations is in Section 6, "Dose."

\section{Sample Collection and Analytical Procedure}

Portsmouth uses thermoluminescent dosimeters (TLDs) to measure gamma radiation exposure. When exposed to penetrating radiation (such as X-ray, gamma, or cosmic radiation), thermoluminescent materials absorb and store a portion of the radiation energy. If the material is later heated, this energy will be released as light. Although thermoluminescent materials (such as clay) are fairly common, only a handful are sufficiently accurate for use in radiation measuring devices (dosimeters).

In the past, Portsmouth used TLDs containing calcium fluoride:dysprosium $\left(\mathrm{CaF}_{2}: \mathrm{Dy}\right)$ chips for environmental surveillance. In late 1992, these TLDs were replaced with ones containing four lithium fluoride (LiF) chips. These are the same type of TLDs used by the Portsmouth Health Physics Department to monitor worker exposure. The older TLDs had been selected for extreme sensitivity at the expense of other parameters. As a result, readings were not easily compared with more standardized systems. Experience with both types of 
TLDs shows that the LiF-based TLDs, although less sensitive, are adequate for monitoring radiation levels around Portsmouth.

The usual concern about the accuracy of a TLD network is the level of ambient or external gamma radiation around Portsmouth. The term "external" is used because the source of the radiation is external to the body. In contrast, internal sources that have been inhaled or swallowed involve nonpenetrating alpha and beta radiation. The only significant sources of gamma radiation at Portsmouth are the uranium isotope ${ }^{235} \mathrm{U}$ and the short-lived uranium daughters.

External gamma measurements are collected in the relatively small area of the Portsmouth site accessible to the public, around the edge of the site, and at the ambient air sampling stations in Piketon (location 6) and at Camp Creek (location 28) (see Fig. 5.1). Nine on-site field TLDs (Site Group I) are located on or near Perimeter Road, which surrounds the secured area of the facility. Eight TLDs (Site Group II) are used in conjunction with the fence-post air monitoring stations discussed in the section on ambient air. Two off-site TLDs provide a general indication of background levels. TLD locations are shown in Figs. 5.1 and 5.2. The TLDs are calibrated and analyzed according to current Health Physics Department procedures.

The external gamma radiation levels for site groups I and II are reported as quarterly site-group averages, with one exception in Site Group I. TLD location 874 is at the corner of a uranium storage yard, where gamma levels are sharply higher than those on the rest of Perimeter Road. This location is reported separately to emphasize that a single "hot spot" exists and that Perimeter Road in general is not an area of elevated gamma levels. This procedure is particularly important when estimating radiation doses from radiation levels. In Site Group II and off-site locations, this calculation is made by multiplying the annual average gamma levels by the potential time exposed (i.e., 24 hours/day, 365 days/year) because a continuous exposure in those areas is a reasonable assumption.

ORNL-DWG 87M-10787R3

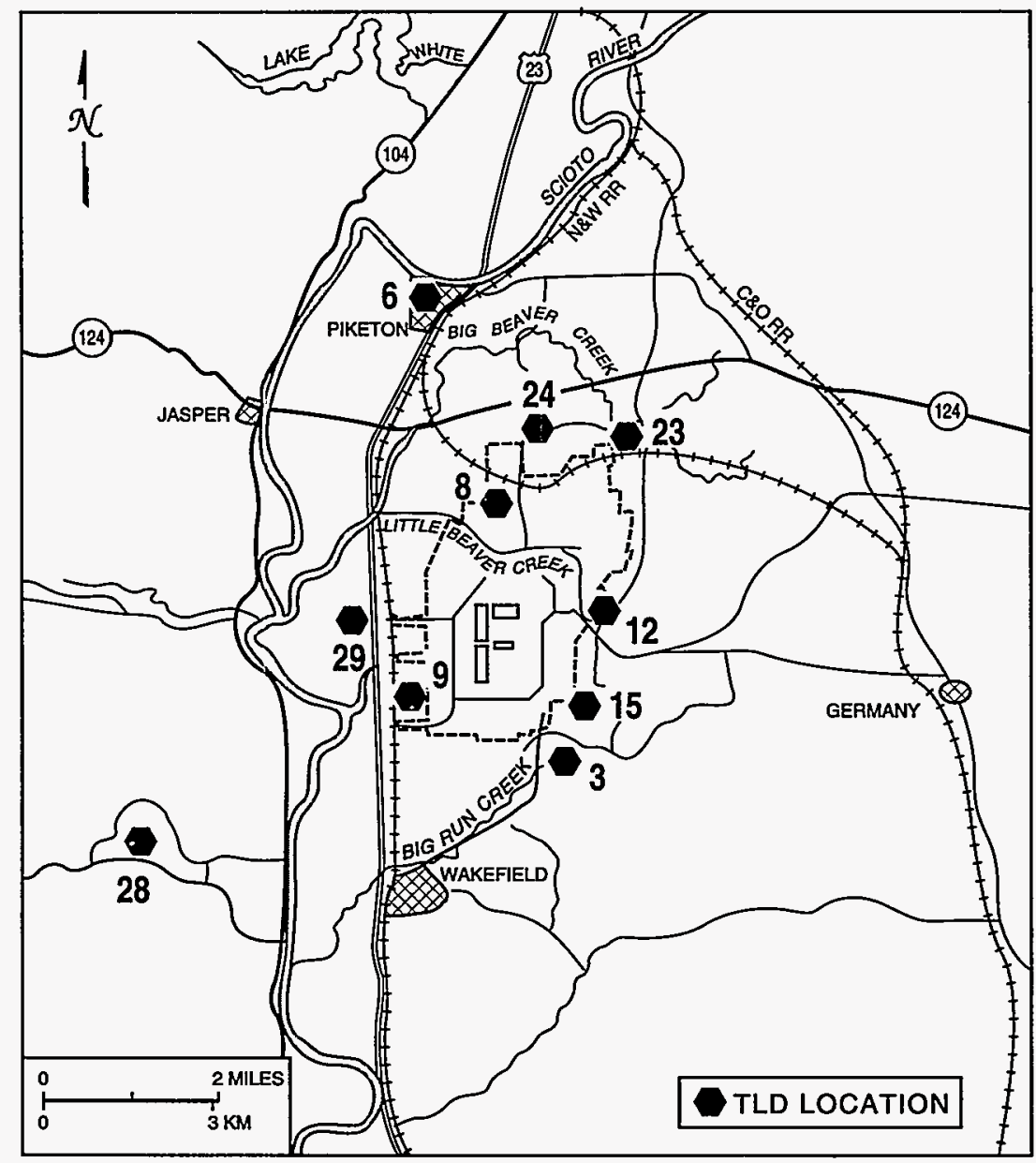

Fig. 5.1. Otf-site TLD locations (Site Group II) at Portsmouth. 
ORNL-DWG 87M-10788R2

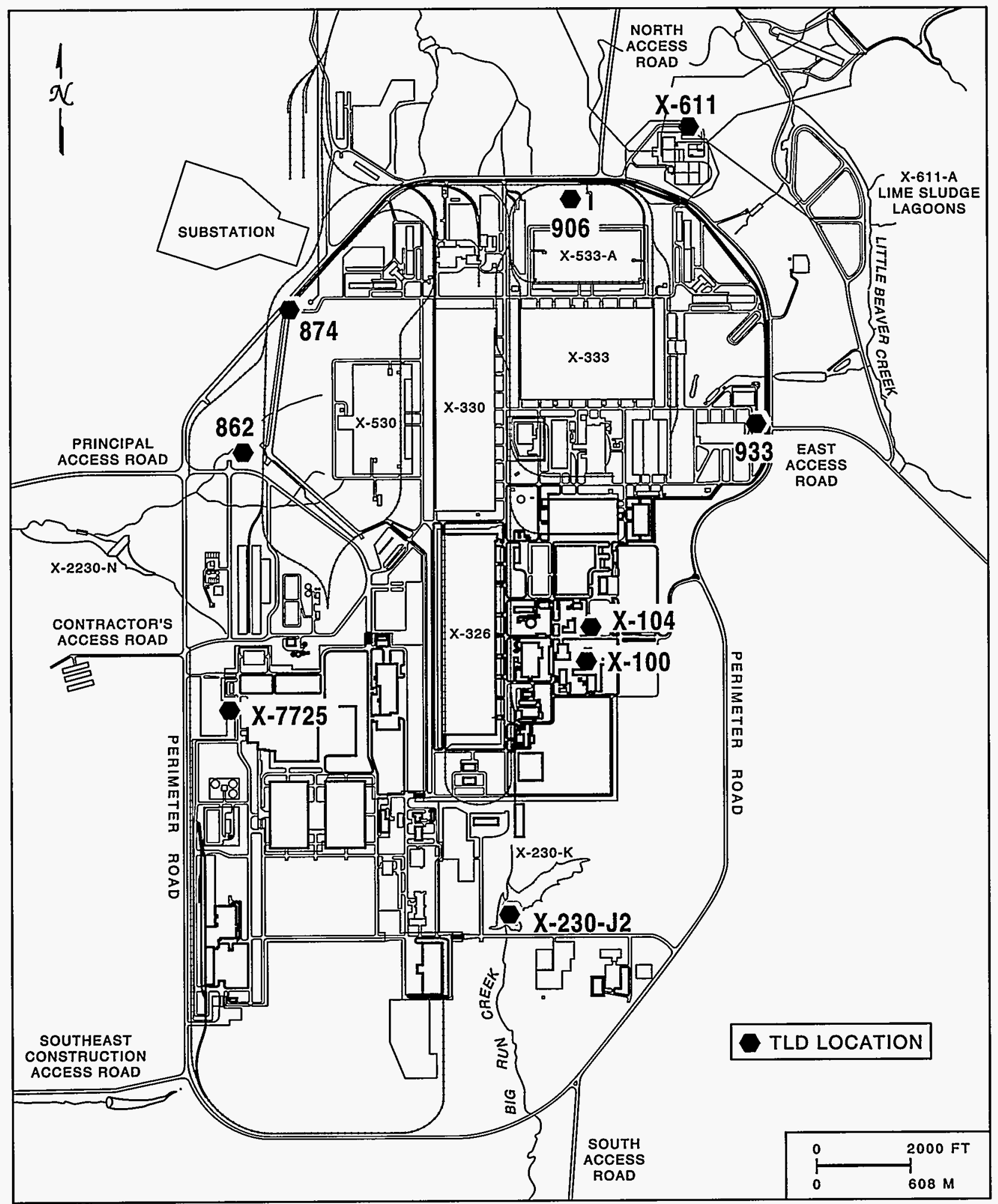

Fig. 5.2. On-site TLD locations (Site Group I) at Portsmouth. 
Public exposure to Site Group I gamma levels is limited to actual travel on Perimeter Road and is much lower than the 24 hours/day, 365 days/year assumed for the other site groups. Because it is impossible to reliably estimate how low this public exposure is and because the average gamma level for the group is not significantly higher than background, a conservative worst-case continuous exposure is assumed for the group average. However, this would not be a reasonable assumption for location 874 . Because location 874 is located away from access roads or security fence gates, it is possible to estimate an annual exposure to members of the general public for this area. Public traffic is not allowed to stop in this area. Tests performed by environmental personnel have shown that a car traveling slightly under the posted speed limit passes through the hot spot in 20 to 30 seconds. Portsmouth therefore calculates the average exposure for an individual driving to and from work. An average of 1 minute in this "hot spot" is considered conservative. Total exposure can then be estimated as equal to the average gamma levels within the hot spot (e.g., half the measured peak gamma level at location 874) times 1 minute per trip times 2 trips per day times 5 workdays per week times 52 weeks per year, or 8.7 hours/year times $1 / 2$ the measured radiation level at location 874 .

\section{Results}

Except for TLD location 874, external gamma levels around Portsmouth are not significantly different from natural background. Table 5.1 shows the average external gamma level (in microrad per hour) plus or minus twice the standard deviation by site group and calendar quarter. Quarterly average gamma levels at location 874 are shown below the data for the rest of Site Group I. The last column shows the estimated gross annual external gamma dose within each of the site groups. For Site Group I, the annual dosage is estimated assuming continuous exposure to the group average radiation levels. The additional dose resulting from the 8.7 hours/year exposure to location 874 is also listed.

Table 5.1. Ambient gamma radiation levels and doses at Portsmouth for 1993

\begin{tabular}{|c|c|c|c|c|c|}
\hline \multirow{2}{*}{ Location } & \multicolumn{4}{|c|}{$\begin{array}{c}\text { Ambient gamma levels } \\
\text { (urad/hour) }\end{array}$} & \multirow{2}{*}{$\begin{array}{c}\text { Annual } \\
\text { dose } \\
\text { (mrem/year }\end{array}$} \\
\hline & $\begin{array}{l}\text { First } \\
\text { quarter }\end{array}$ & $\begin{array}{l}\text { Second } \\
\text { quarter }\end{array}$ & $\begin{array}{l}\text { Third } \\
\text { quarter }\end{array}$ & $\begin{array}{l}\text { Fourth } \\
\text { quarter }\end{array}$ & \\
\hline Site Group I & $10.2 \pm 2.7$ & $18.3 \pm 6.3$ & $12.8 \pm 7.8$ & $13.5 \pm 3.9$ & 118 \\
\hline Location $874^{a}$ & 62.6 & 89.6 & 72.6 & 84.9 & 0.33 \\
\hline Site Group II & $10.6 \pm 2.4$ & $20.5 \pm 10.6$ & $11.7 \pm 3.2$ & $14.4 \pm 4.5$ & 122 \\
\hline Piketon $(6)^{b}$ & 10.9 & 18.6 & 11.1 & 11.9 & 113 \\
\hline Camp Creek (28) & 9.9 & 16.4 & 11.0 & 13.7 & 111 \\
\hline
\end{tabular}

Not included in Site Group I averages or standard deviations.

${ }^{b}$ See Fig. 5.1.

The numbers in Table 5.1 represent gross gamma levels and doses, including gamma radiation from Portsmouth activities and effluents, local natural sources (i.e., terrestrial gamma), and cosmic radiation. No effort has been made to separate natural radiation from the Portsmouth contribution. In theory, this could be done by subtracting the external gamma level at a background location from external gamma levels at all the other locations. Historically, TLDs at most of the off-site locations (now discontinued) around Portsmouth have recorded higher gamma levels than the potentially more exposed TLDs on and within the site boundary. The cause of this phenomenon lies in the geology of the Portsmouth site. The Portsmouth plant is located within an ancient river bed that was filled with clay and silt during the glacial period. The surrounding hills and ridges, on the other hand, are largely composed of much older shale that is significantly richer in natural radioactive minerals. Most of the discontinued off-site TLDs were located near these hills and ridges, where they were exposed to a higher level of radiation than the on-site TLDs. Consequently, no legitimate background level of radiation could be designated. However, plant emissions that are consistently lower than the local variation in natural background radiation can hardly be called significant. 
Piketon, the off-site location of another TLD, is located in the Scioto River valley (which is within the older Newark River valley). The geographic setting is comparable to the Site Group II TLDs. If Piketon were not the nearest population center to the plant site, this might well be a usable background location. On the other hand, ambient radiation levels at a Camp Creek location have historically been consistently lower than any other location monitored by Portsmouth. This includes locations farther from the plant. Apparently, the geography at Camp Creek is unusual, and this location cannot be used to establish a background standard for Portsmouth ambient radiation levels. However, radiation levels do remain consistent at this location. The low levels recorded are compared with levels at other areas. For comparison, Fig. 5.3 shows the annual gross external radiation dose for each of the two site groups and the two off-site TLDs and the published average annual doses for the state of Ohio and the United States as a whole. As indicated, gamma levels within the Portsmouth reservation, at Piketon, and at Camp Creek are close to the state average, whereas the gamma levels near the reservation boundary (within or near the local shale hills) are slightly higher. This is consistent with private surveys of ambient gamma levels in south-central Ohio, which report the average gamma levels for the entire region to be equivalent to $120 \mathrm{mrem} / \mathrm{year}$. For a more general comparison refer to Fig. 5.4, which shows the average annual doses from terrestrial gamma, cosmic, and total radiation for several states and the entire United States.

\section{AMBIENT AIR}

This section describes the ambient air monitoring network maintained by Portsmouth and includes a summary of the ambient air data at each of the air monitoring stations.

\section{Sample Collection and Analytical Procedure}

In 1964, Portsmouth established a network of on-site and off-site permanent stations to collect continuous ambient air samples. Figures 5.5 and 5.6 show the station locations in the current network. Strictly speaking, the locations in Fig. 5.5 are not "ambient" as the U.S. Environmental Protection Agency (USEPA) defines it. The USEPA definition requires "unrestricted access by members of the public." Portsmouth monitors at these six locations because the public does have some access to these areas and because any problems resulting from airborne emissions will be detected at these locations long before they become evident at the more distant locations shown in Fig. 5.6. Each station consists of a Teflon particulate filter, a chemically treated filter for gaseous fluorides, a flow controller, gas meter, and a vacuum pump. The particulate filters are collected monthly and subjected to gross alpha and beta-gamma counts. If.the gross counts exceed

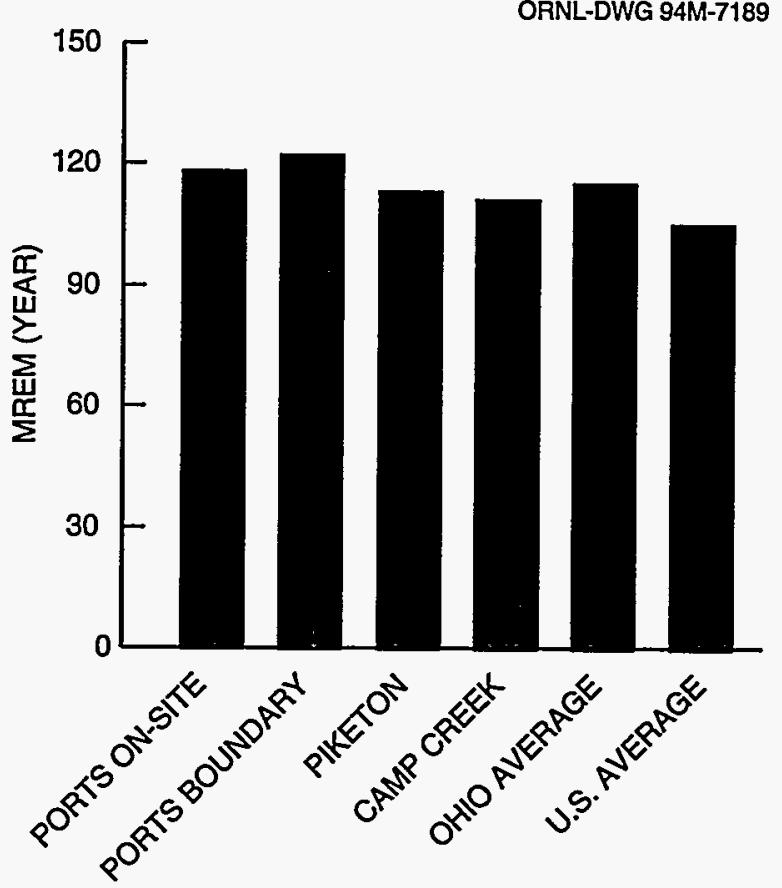

Fig. 5.3. Average annual external gamma exposure on and around the Portsmouth site, for the state of Ohio, and for the United States as a whole.

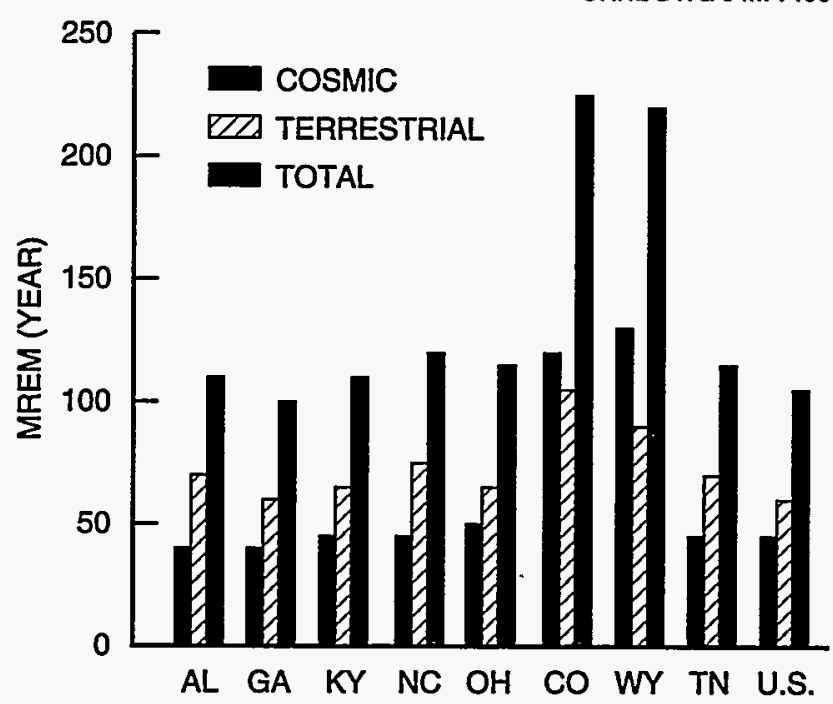

Fig. 5.4. External cosmic, terrestrial, and total gamma exposure for several states and the United States as a whole. 
ORNL-DWG 87M-10130R2

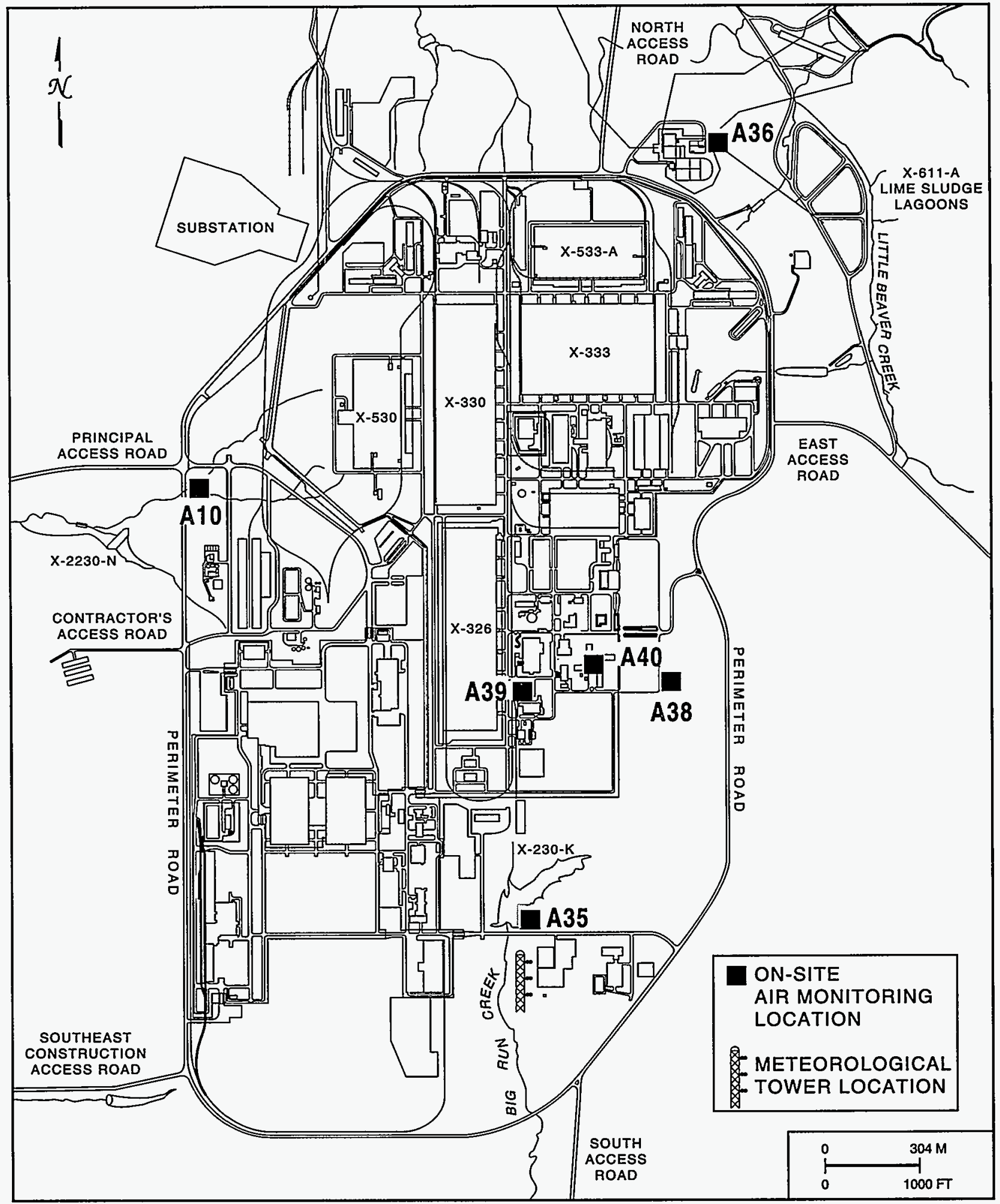

Fig. 5.5. On-site monitoring and meteorological tower locations at Portsmouth. 


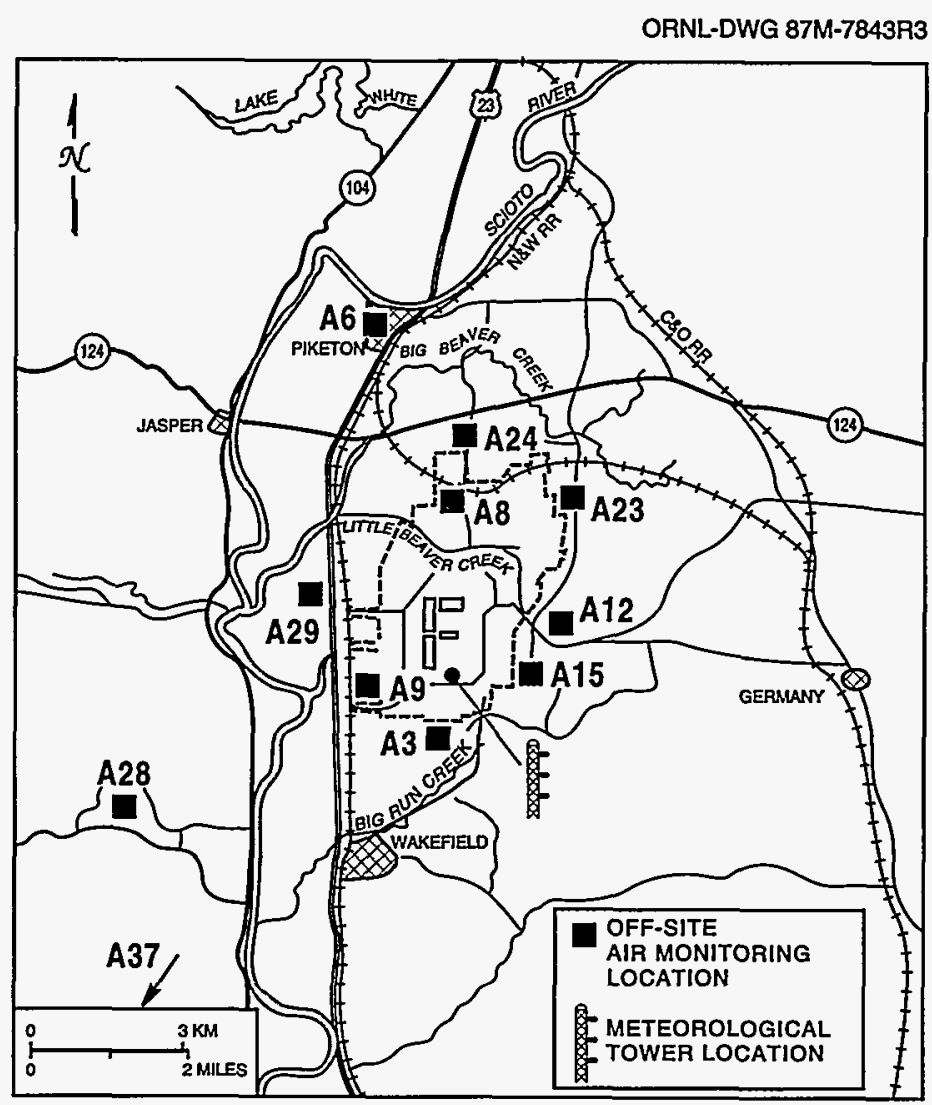

Fig. 5.6. Off-site air monitoring locations at Portsmouth.

plant-established limits ( $100 \mathrm{dpm}$ alpha or $200 \mathrm{dpm}$ beta-gamma), the filters are analyzed for specific radionuclides. To date, air samples have never exceeded the plant-established limits. All filters indicating positive counts are retained for an annual composite analysis (for specific radionuclides to verify that no unexpected radionuclides are being discharged to the air). The treated filters are collected weekly and analyzed for total fluorides. The particulate filters and the gaseous fluoride filters are mounted in separate Teflon filter holders to prevent cross contamination and to simplify handling.

In June 1993, Portsmouth installed three high-volume particulate samplers near existing air monitors at stations A8, A12, and A37 (see Fig. 5.6). These monitors use 8- $\times 10$-in. glass fiber filters and operate at approximately $40 \mathrm{ft}^{3} /$ minute. The monitors are used exclusively for particulate radionuclides. Fluoride sample data are still obtained from the original low-volume samplers. Data from the high-volume samplers are used to confirm results from the original low-volume samplers. This is particularly helpful in verifying that radioactive emissions from Portsmouth are virtually indistinguishable from background radiation levels at the locations of the three high-volume samplers. In October 1993, ambient air monitors were removed from three on-site locations (A35, A38, and A39) for use in an investigation of the air medium at Portsmouth under the Resource Conservation and Recovery Act (RCRA). This investigation is referred to as the Air RFI (RCRA facility investigation). The temporary loss of data from these locations will not adversely affect the protection of the public because the fence-line monitors, not the on-site monitors, are used for that purpose.

\section{Results}

Tables 5.2 and 5.3 contain summaries of the airborne gross alpha and beta-gamma radiation concentrations in and around Portsmouth recorded in 1993. The tables include the number of samples collected; the maximum, minimum, and average concentrations in the samples; and the standard deviation of the concentrations at each air station. Note that the standard deviations are on the same order of magnitude as the average concentrations. The deviations are greater than the differences noted among most of the average concentrations, indicating large variations at each station. This indicates that small differences in the average concentrations are probably not significant. 
Table 5.2. Gross alpha concentrations in ambient air at Portsmouth for 1993

\begin{tabular}{lccccc}
\hline & No. of & \multicolumn{3}{c}{$\begin{array}{c}\text { Concentration } \\
\left(\mathrm{pCi} / \mathrm{m}^{3}\right)\end{array}$} & $\begin{array}{c}\text { Standard } \\
\text { deviation }\end{array}$ \\
\cline { 3 - 5 } & samples & Max & Min & Av & \\
\cline { 3 - 5 } A10 & $12(10)^{a}$ & 0.009 & $<0.003$ & $<0.004$ & 0.001 \\
A35 & $8(7)^{a}$ & 0.005 & $<0.003$ & $<0.004$ & 0.001 \\
A36 & $12(9)^{a}$ & 0.012 & $<0.003$ & $<0.005$ & 0.002 \\
A38 & $9(8)^{a}$ & 0.014 & $<0.003$ & $<0.005$ & 0.003 \\
A39 & $9(2)^{a}$ & 0.026 & $<0.003$ & $<0.011$ & 0.008 \\
A40 & $12(5)^{a}$ & 0.014 & $<0.003$ & $<0.006$ & 0.003 \\
& & Property line & & \\
A3 & $12(6)^{a}$ & 0.009 & $<0.003$ & $<0.004$ & 0.001 \\
A8 & $12(10)^{a}$ & 0.006 & $<0.003$ & $<0.004$ & 0.001 \\
A9 & $12(7)^{a}$ & 0.009 & $<0.003$ & $<0.005$ & 0.002 \\
A12 & $11(10)^{a}$ & $<0.005$ & $<0.003$ & $<0.004$ & 0.001 \\
A15 & $12(10)^{a}$ & 0.005 & $<0.003$ & $<0.004$ & 0.001 \\
A23 & $12(8)^{a}$ & 0.007 & $<0.003$ & $<0.005$ & 0.001 \\
A24 & $12(9)^{a}$ & 0.004 & $<0.003$ & $<0.004$ & 0.001 \\
A29 & $11(8)^{a}$ & 0.008 & $<0.003$ & $<0.005$ & 0.002 \\
& & & Off-site & & \\
A6 & $11(9)^{a}$ & 0.005 & $<0.003$ & $<0.004$ & 0.001 \\
A28 & $12(11)^{a}$ & $<0.006$ & $<0.003$ & $<0.004$ & 0.001 \\
A37 & $12(9)^{a}$ & 0.006 & $<0.003$ & $<0.004$ & 0.001 \\
\hline
\end{tabular}

${ }^{a}$ Number of samples below the lower limit of detection.

The highest monthly ambient concentration of alpha and the highest monthly and annual average beta-gamma levels recorded in 1993 were found at station A9, located on the southwest corner of the plant. Stations A23 and A29 had the same annual average alpha concentrations as A9 but lower monthly maximums. None of the concentrations were statistically significant as evidenced by the magnitude of the standard deviations. (The increased technetium emissions, for instance, are more evident in the data reflecting individual monthly concentrations recorded at the monitoring stations closest to the X-326 process building, A39 and A40).

Annual average alpha concentrations of 0.004 to $0.005 \mathrm{pCi} / \mathrm{m}^{3}$ were detected at all property-line and off-site stations. The detection limit is $0.001 \mathrm{pCi} / \mathrm{m}^{3}$. The maximum monthly reading detected was $0.009 \mathrm{pCi} / \mathrm{m}^{3}$ at stations $\mathrm{A} 9$ and $\mathrm{A} 3$. Annual average gross beta-gamma concentrations at the reservation boundary ranged from 0.037 to $0.051 \mathrm{pCi} / \mathrm{m}^{3}$, with an annual average background concentration of $0.030 \mathrm{pCi} / \mathrm{m}^{3}$ and a maximum monthly background concentration of $0.067 \mathrm{pCi} / \mathrm{m}^{3}$. The background concentrations are measured at station $\mathrm{A37}$, which is located approximately $21 \mathrm{~km}$ (13 miles) from the plant, near the community of Otway.

The data in Tables 5.2 and 5.3 are "gross" concentrations. Included are all alpha and beta-gamma emitters present around Portsmouth, such as emissions from Portsmouth operations, emissions from other facilities (coal, for instance, includes radioactive constituents that are released from coal-fired power plants in considerable quantities), and naturally occurring radionuclides from the local soil. Portsmouth also estimates "net" concentrations resulting from its emissions only. The average background measured near Otway is subtracted from the highest annual average concentration measured around the DOE reservation boundary. In 1993, the

\section{5-8 Environmental Surveillance}


Table 5.3. Gross beta-gamma concentrations in ambient air at Portsmouth for 1993

\begin{tabular}{|c|c|c|c|c|c|}
\hline \multirow{2}{*}{ Location } & \multirow{2}{*}{$\begin{array}{c}\text { No. of } \\
\text { samples }\end{array}$} & \multicolumn{3}{|c|}{$\begin{array}{l}\text { Concentration } \\
\left(\mathrm{pCi} / \mathrm{m}^{3}\right)\end{array}$} & \multirow{2}{*}{$\begin{array}{l}\text { Standard } \\
\text { deviation }\end{array}$} \\
\hline & & Max & Min & $\mathrm{Av}$ & \\
\hline \multicolumn{6}{|c|}{ On-site } \\
\hline $\mathrm{A} 10$ & $12(0)^{a}$ & 0.138 & 0.015 & 0.057 & 0.040 \\
\hline A35 & $8(0)^{a}$ & 0.082 & 0.012 & 0.044 & 0.023 \\
\hline A36 & $12(0)^{a}$ & 0.543 & 0.030 & 0.097 & 0.136 \\
\hline A38 & $9(0)^{a}$ & 0.165 & 0.021 & 0.089 & 0.048 \\
\hline A39 & $9(0)^{a}$ & 1.616 & 0.075 & 0.527 & 0.521 \\
\hline $\mathrm{A} 40$ & $12(0)^{a}$ & 0.425 & 0.014 & 0.169 & 0.135 \\
\hline \multicolumn{6}{|c|}{ Property line } \\
\hline $\mathrm{A} 3$ & $12(0)^{a}$ & 0.073 & 0.014 & 0.045 & 0.018 \\
\hline A8 & $12(1)^{a}$ & 0.092 & $<0.010$ & $<0.041$ & 0.021 \\
\hline A9 & $12(0)^{a}$ & 0.165 & 0.022 & 0.051 & 0.036 \\
\hline $\mathrm{A} 12$ & $11(1)^{a}$ & 0.079 & $<0.008$ & $<0.039$ & 0.020 \\
\hline A15 & $12(2)^{a}$ & 0.087 & $<0.007$ & $<0.045$ & 0.027 \\
\hline A23 & $12(1)^{a}$ & 0.074 & $<0.009$ & $<0.045$ & 0.019 \\
\hline A24 & $12(1)^{a}$ & 0.059 & $<0.008$ & $<0.037$ & 0.014 \\
\hline A29 & $11(0)^{a}$ & 0.077 & 0.005 & 0.043 & 0.022 \\
\hline \multicolumn{6}{|c|}{ Off-site } \\
\hline A6 & $11(0)^{a}$ & 0.060 & 0.011 & 0.034 & 0.013 \\
\hline A28 & $12(2)^{a}$ & 0.099 & $<0.007$ & $<0.033$ & 0.024 \\
\hline A37 & $12(1)^{a}$ & 0.067 & $<0.006$ & $<0.030$ & 0.016 \\
\hline
\end{tabular}

${ }^{a}$ Number of samples below the lower limit of detection.

highest net average alpha concentration around the $\mathrm{DOE}$ reservation boundary was $0.001 \mathrm{pCi} / \mathrm{m}^{3}$. The highest net average beta-gamma concentration was $0.021 \mathrm{pCi} / \mathrm{m}^{3}$. Low ambient air concentrations confirm that emissions from the plant are indeed well below the allowable limit and further substantiate the data collected from the continuous stack samplers. The ambient data also confirm that no significant amounts of radionuclides are being released from unmonitored minor sources. One disadvantage of low ambient concentrations is that it is difficult to analyze for specific radionuclides (e.g., uranium and technetium). Portsmouth therefore assumes that all the net alpha concentration is from uranium emissions relating to plant operations. Another assumption is that all of the net beta-gamma concentration is from technetium and uranium daughters in the same proportion as the measured emissions.

Table 5.4 provides results of the weekly ambient fluoride samples collected in 1993. Ambient air quality standards from Kentucky and Tennessee are used for comparison because standards for ambient gaseous fluorides have not been issued in the state of Ohio. Kentucky regulations include a primary (i.e., public health) standard of $400 \mu \mathrm{g} / \mathrm{m}^{3}$ (annual average) and a secondary (i.e., public welfare) standard of $1.6 \mu \mathrm{g} / \mathrm{m}^{3}$ (7-day average). Tennessee regulations include both primary and secondary standards of $1.6 \mu \mathrm{g} / \mathrm{m}^{3}$ (7-day average). All of the 7-day fluoride concentrations, both on- and off-site, were well below the 7-day standard of $1.6 \mu \mathrm{g} / \mathrm{m}^{3}$ established in Kentucky and Tennessee. The highest 7-day average recorded on-site was $0.89 \mu \mathrm{g} / \mathrm{m}^{3}$ at station A40, which is downwind of the largest fluoride source. The highest 7-day average recorded off-site, $0.35 \mu \mathrm{g} / \mathrm{m}^{3}$, 
Table 5.4. Total gaseous fluoride concentrations (as HF) in ambient air at Portsmouth for 1993

\begin{tabular}{|c|c|c|c|c|c|}
\hline \multirow[t]{2}{*}{ Location } & \multirow{2}{*}{$\begin{array}{c}\text { No. of } \\
\text { samples }\end{array}$} & \multicolumn{3}{|c|}{$\begin{array}{c}\text { Concentration } \\
\left(\mu \mathrm{g} / \mathrm{m}^{3}\right)\end{array}$} & \multirow{2}{*}{$\begin{array}{l}\text { Standaro } \\
\text { deviation }\end{array}$} \\
\hline & & $\operatorname{Max}$ & Min & Av & \\
\hline \multicolumn{6}{|c|}{ On-site } \\
\hline A10 & $52(19)^{a}$ & 0.37 & $<0.05$ & $<0.09$ & 0.049 \\
\hline A35 & $37(11)^{a}$ & 0.19 & $<0.05$ & $<0.10$ & 0.035 \\
\hline A36 & $53(17)^{a}$ & 0.23 & $<0.06$ & $<0.12$ & 0.038 \\
\hline A38 & $40(6)^{a}$ & 0.27 & $<0.06$ & $<0.15$ & 0.053 \\
\hline A39 & $41(5)^{a}$ & 0.58 & $<0.05$ & $<0.26$ & 0.153 \\
\hline A40 & $52(11)^{a}$ & 0.89 & $<0.05$ & $<0.17$ & 0.131 \\
\hline \multicolumn{6}{|c|}{ Property line } \\
\hline A3 & $53(21)^{a}$ & 0.18 & $<0.05$ & $<0.10$ & 0.031 \\
\hline A8 & $51(27)^{a}$ & 0.33 & $<0.05$ & $<0.09$ & 0.044 \\
\hline A9 & $53(25)^{a}$ & 0.20 & $<0.05$ & $<0.09$ & 0.031 \\
\hline $\mathrm{A} 12$ & $53(15)^{a}$ & 0.22 & $<0.05$ & $<0.10$ & 0.034 \\
\hline A.15 & $51(21)^{a}$ & 0.20 & $<0.04$ & $<0.09$ & 0.031 \\
\hline A23 & $53(32)^{a}$ & 0.35 & $<0.06$ & $<0.11$ & 0.050 \\
\hline A24 & $53(13)^{a}$ & 0.19 & $<0.06$ & $<0.10$ & 0.033 \\
\hline A29 & $51(28)^{a}$ & 0.16 & $<0.05$ & $<0.08$ & 0.026 \\
\hline \multicolumn{6}{|c|}{ Off-site } \\
\hline A6 & $52(31)^{a}$ & 0.20 & $<0.06$ & $<0.09$ & 0.026 \\
\hline A28 & $53(22)^{a}$ & 0.26 & $<0.06$ & $<0.10$ & 0.041 \\
\hline A37 & $52(19)^{a}$ & 0.17 & $<0.06$ & $<0.09$ & 0.025 \\
\hline
\end{tabular}

"Number of samples below the lower limit of detection.

was documented at station A23, northeast of the plant. The second-highest 7-day average calculated was $0.33 \mu \mathrm{g} / \mathrm{m}^{3}$, which was recorded at station A8, north-northwest of the plant.

\section{Meteorological Monitoring}

Portsmouth maintains a single meteorological tower (see Fig. 5.5) equipped with instrument packages at the 10-m and 40-m levels. Air temperature, relative humidity, and wind speed and direction are measured at both levels. In addition, ground-level instrumentation measures solar radiation, barometric pressure, precipitation, and soil temperature at 0.30 - and $0.61-\mathrm{m}(\sim 1-$ and $2-\mathrm{ft})$ depths. The tower was struck by lightning July 11,1990 , damaging one complete set of instruments. The other set of instruments, which had just been removed for calibration, were hurriedly reinstalled. The instruments, however, were considered obsolete, and newer instruments were deemed incompatible with the system. A portable meteorological system was borrowed from the National Oceanic and Atmospheric Administration (NOAA) in October 1990 and became operational November 5, 1990. In late 1991, the NOAA instruments were mounted on the Portsmouth tower. Data from the two sets of instruments were incompatible. In summer 1993, the tower was struck by lightning at least twice, the last strike occurring July 1 . When personnel attempted to remove the instruments for repair, the elevator cable broke, plummeting the instruments to the ground. New instruments, which had been procured for a new 
meteorological tower, were installed on the tower. The system now complies with NOAA and USEPA guidelines. Meteorological data were recorded with NOAA instrumentation for the first six months of 1993 and with Portsmouth instruments for the last six months; these instruments are compatible.

Two microprocessors at the foot of the tower convert analog data from the instruments to digital data. The microprocessors calculate both 15- and 60-minute summary data. These data are transmitted by radio to the X-1020 emergency operations center and then to an IBM PC-compatible computer. The data are stored on the PC hard disk and are backed up to floppy diskettes. Each midnight, hourly data, daily averages, and totals are printed on a console for archival purposes. The 15-minute data are transmitted to video terminals in the X-300 process control building and to the Air and Water Policy Department.

Figures 5.7 and 5.8 are standard graphic presentations of wind speed and direction data called "wind roses." Each wind rose has 16 arms (representing the standard 16 wind directions), each of which is divided into 6 segments (representing 6 wind speed classes). The length of each segment represents the fraction of time that wind was blowing from that direction at an average speed within that class. The key at the bottom of the figure includes the maximum speed of each wind speed class except the last, which includes all wind speeds above the first five classes. The primary use of a wind rose is to provide an easily understood picture of the prevailing wind patterns at a site. The relative length of the arms gives a quick indication of which wind directions predominate and to what extent.

A joint frequency distribution is defined as a set of tables that lists the fraction of time in each of 576 wind classes (16 directions $\times 6$ wind speeds $\times 6$ atmospheric stability classes) instead of the 96 classes of a wind rose (16 directions $\times 6$ wind speeds only). Atmospheric stability can be described roughly as the tendency of wind to mix with and dilute a pollutant as opposed to merely transporting it downwind. The stability classes range from A (extremely unstable, maximum mixing), through $\mathrm{D}$ (neutral), to $\mathrm{F}$ (moderately stable, minimum mixing). Because of their complexity, joint frequency distributions are more useful as input for computer models than for data presentation. Such computer models (known as "air dispersion models") are used to predict the downwind spread of pollutants. The USEPA requires that one such model, AIRDOS-USEPA, be produced to demonstrate compliance with the National Emission Standards for Hazardous Air Pollutants radiation dose limits (see Section 2, "Environmental Compliance").

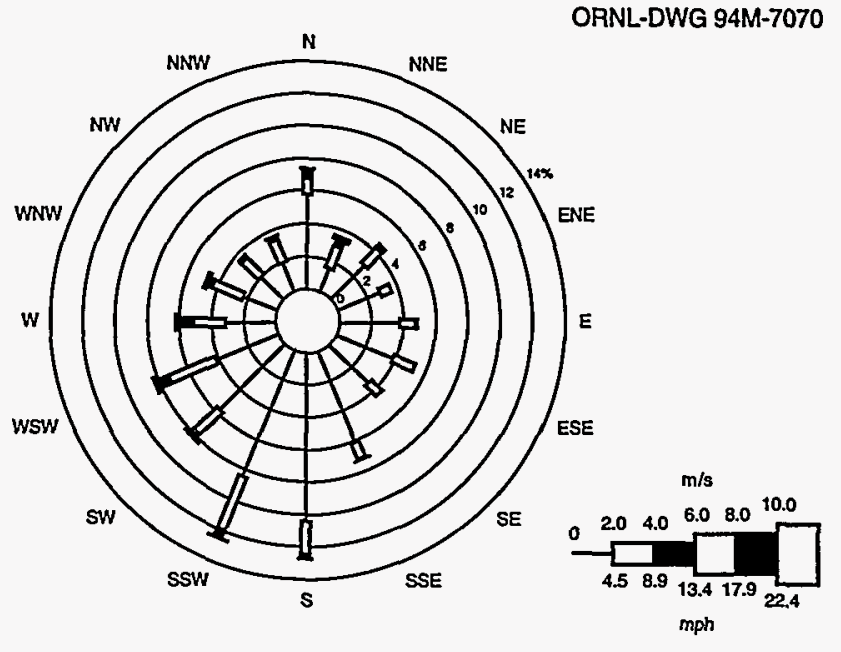

Fig. 5.7. Wind rose (10-m level) showing wind speed frequency distribution data (with $90.2 \%$ of possible data) used for 1993 estimates.

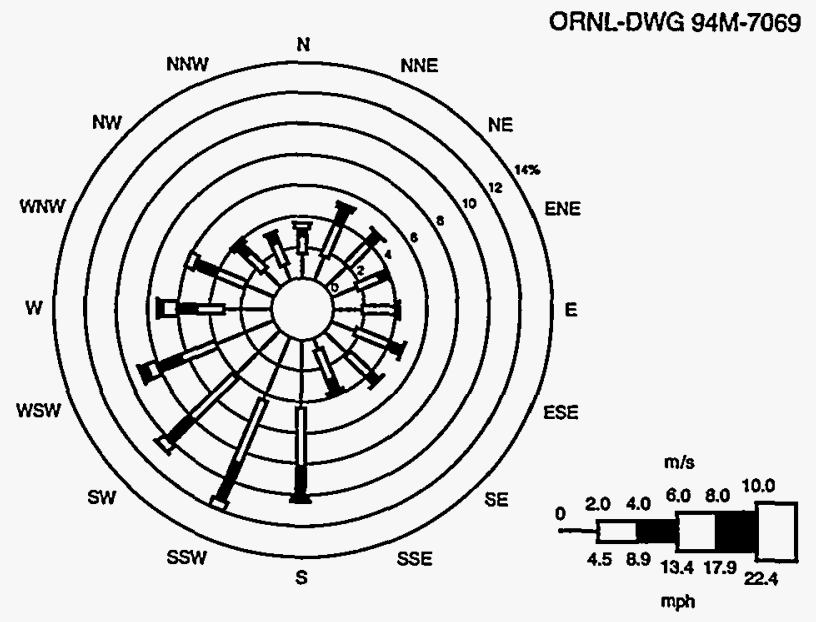

Fig. 5.8. Wind rose $(40-\mathrm{m}$ level) showing wind speed frequency distribution data (with $90.9 \%$ of possible data) used for 1993 estimates. 


\section{SURFACE WATER}

The receiving streams around Portsmouth are monitored for radioactive and nonradioactive constituents at designated routine water (RW) sampling locations (Fig. 5.9). The primary parameters for the RW sampling program are radiological, but fluoride and phosphate levels in the Scioto River are also monitored.

Aqueous fluorides could be discharged to the Scioto River in treated wastewaters from decontamination and uranium recovery operations via the X-6619 sewage treatment plant (outfall 003). Phosphates are discharged to the river in "blowdown" from the recirculating cooling water system via outfall 004 . Portsmouth formerly used a chromate-based corrosion inhibitor in the plant recirculating cooling water system. The X-616 wastewater treatment facility (outfall 004) was constructed to remove chromates from the blowdown water before discharge to the river. Conversion to a phosphate-based corrosion inhibitor was completed in 1991, and the X-616 facility is now used strictly as a pumping station and National Pollutant Discharge Elimination System (NPDES) monitoring point.

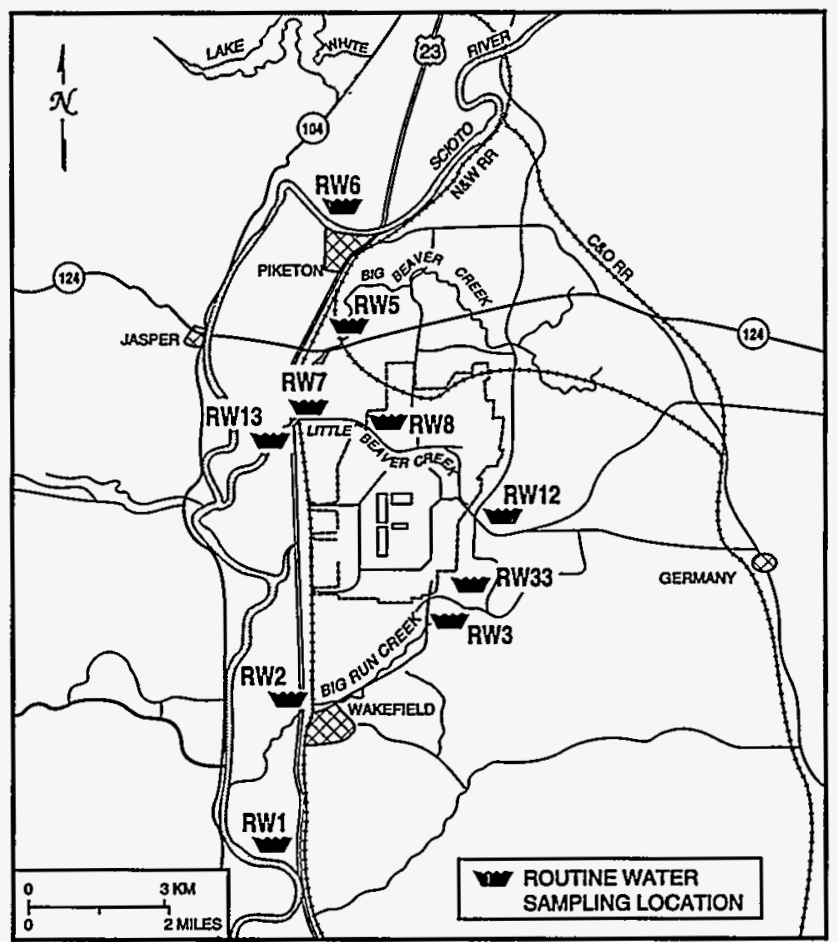

Fig. 5.9. Routine surface water sampling locations (nonNPDES) at Portsmouth.

\section{Sample Collection and Analytical Procedure}

Grab samples of local surface waters are collected by technicians of the Environmental and Waste Management Division in accordance with documented procedures. The Scioto River and RW location 8 in Little Beaver Creek are sampled weekly. All other RW locations are sampled monthly.

The RW samples are analyzed for gross alpha and gross beta radioactivity, technetium radioactivity, and total uranium concentration. In addition, RW samples from the Scioto River (RW6 upstream and RW1 downstream) are analyzed for fluorides and phosphates.

\section{Results}

Results of the RW radiological analyses are summarized in Tables 5.5 through 5.8. The radiological parameters are consistently less than applicable drinking water standards. Fluoride and phosphate analyses indicate that discharges of these chemicals are having no effect on the Scioto River.

The maximum uranium concentration reported fróm any RW sample (Table 5.5) was only $0.007 \mathrm{mg} / \mathrm{L}$ $(7 \mathrm{ppb})$. The highest annual average concentration at any location was $0.003 \mathrm{mg} / \mathrm{L}(3 \mathrm{ppb})$. For comparison, the USEPA. has proposed a national primary drinking water standard for uranium of $20 \mathrm{ppb}$.

The maximum gross alpha activity in RW samples (Table 5.6) was $30 \mathrm{pCi} / \mathrm{L}$, with the highest annual average of $9 \mathrm{pCi} / \mathrm{L}$ at the same location. This is less than $2 \%$ of the DOE derived concentration guideline (DCG) for uranium isotopes.

The ${ }^{99} \mathrm{Tc}$ radioactivity in RW samples (Table 5.7) was usually below the detection limit of $22 \mathrm{pCi} / \mathrm{L}$, as reflected by annual average levels that are only slightly above the detection limit. The maximum technetium concentration reported in 1993 was only $88 \mathrm{pCi} / \mathrm{L}$. Annual average concentrations at all RW locations were less than $0.025 \%$ of the DOE DCG for ${ }^{99} \mathrm{Tc}$. For further comparison, the USEPA national primary drinking water 
Table 5.5. Uranium in water samples at Portsmouth for 1993

\begin{tabular}{|c|c|c|c|c|c|}
\hline \multirow{2}{*}{$\begin{array}{l}\text { Sample } \\
\text { location }\end{array}$} & \multirow{2}{*}{$\begin{array}{l}\text { No. of } \\
\text { samples }\end{array}$} & \multicolumn{3}{|c|}{$\begin{array}{l}\text { Concentration } \\
(\mathrm{mg} / \mathrm{L})\end{array}$} & \multirow{2}{*}{$\begin{array}{l}\text { Standard } \\
\text { deviation }\end{array}$} \\
\hline & & $\operatorname{Max}$ & Min & $\mathrm{Av}$ & \\
\hline \multicolumn{6}{|c|}{ Little Beaver Creek } \\
\hline RW7 & 12 & 0.006 & $<0.001$ & $<0.003$ & 0.001 \\
\hline RW8 & 48 & 0.007 & 0.001 & 0.003 & 0.001 \\
\hline RW12 & 12 & $<0.001$ & $<0.001$ & $<0.001$ & 0.000 \\
\hline \multicolumn{6}{|c|}{ Big Beaver Creek } \\
\hline RW5 & 12 & 0.003 & $<0.001$ & $<0.001$ & 0.001 \\
\hline RW13 & 12 & 0.003 & $<0.001$ & $<0.002$ & 0.001 \\
\hline \multicolumn{6}{|c|}{ Big Run Creek } \\
\hline RW2 & 12 & $<0.001$ & $<0.001$ & $<0.001$ & 0.000 \\
\hline RW3 & 12 & 0.002 & $<0.001$ & $<0.002$ & 0.005 \\
\hline RW33 & 12 & $<0.001$ & $<0.001$ & $<0.001$ & 0.000 \\
\hline \multicolumn{6}{|c|}{ Scioto River } \\
\hline RW1 & 51 & 0.003 & $<0.001$ & $<0.002$ & 0.001 \\
\hline RW6 & 51 & 0.003 & $<0.001$ & $<0.002$ & 0.001 \\
\hline
\end{tabular}

Table 5.6. Gross alpha radioactivity in water samples at Portsmouth for 1993

\begin{tabular}{|c|c|c|c|c|c|c|}
\hline \multirow{2}{*}{$\begin{array}{l}\text { Sample } \\
\text { location }\end{array}$} & \multirow{2}{*}{$\begin{array}{l}\text { No. of } \\
\text { samples }\end{array}$} & \multicolumn{3}{|c|}{$\begin{array}{l}\text { Concentration } \\
(\mathrm{pCi} / \mathrm{L})\end{array}$} & \multirow{2}{*}{$\begin{array}{c}\mathrm{DCG}^{a} \\
(\%)\end{array}$} & \multirow{2}{*}{$\begin{array}{l}\text { Standard } \\
\text { deviation }\end{array}$} \\
\hline & & $\operatorname{Max}$ & Min & $\mathrm{Av}$ & & \\
\hline \multicolumn{7}{|c|}{ Little Beaver Creek } \\
\hline RW7 & 12 & 24 & $<5$ & $<8.6$ & $<1.7$ & 5.3 \\
\hline RW8 & 48 & 30 & $<4$ & $<9.0$ & $<1.8$ & 5.6 \\
\hline RW12 & 12 & $<8$ & $<1$ & $<5.4$ & $<1.1$ & 1.6 \\
\hline \multicolumn{7}{|c|}{ Big Beaver Creek } \\
\hline RW5 & 12 & 30 & $<4$ & $<7.2$ & $<1.4$ & 7.2 \\
\hline RW13 & 12 & 9 & $<5$ & $<5.9$ & $<1.2$ & 1.1 \\
\hline \multicolumn{7}{|c|}{ Big Run Creek } \\
\hline RW2 & 12 & $<10$ & $<6$ & $<7.3$ & $<1.5$ & 1.5 \\
\hline RW3 & 12 & $<11$ & $<6$ & $<8.6$ & $<1.7$ & 1.7 \\
\hline RW33 & 12 & $<6$ & $<4$ & $<5.3$ & $<1.1$ & 0.8 \\
\hline \multicolumn{7}{|c|}{ Scioto River } \\
\hline RW1 & 51 & 12 & $<5$ & $<7.0$ & $<1.4$ & 1.4 \\
\hline RW6 & 51 & 14 & $<4$ & $<6.9$ & $<1.4$ & 1.6 \\
\hline
\end{tabular}

${ }^{a}$ DCGs are radionuclide specific and are not applicable to gross alpha activity. Portsmouth assumes gross alpha is dominated by uranium and uses the DCG for ${ }^{234} \mathrm{U}$ for comparison. 
Table 5.7. Technetium-99 concentrations in water samples at Portsmouth for 1993

\begin{tabular}{|c|c|c|c|c|c|c|}
\hline \multirow{2}{*}{$\begin{array}{l}\text { Sample } \\
\text { location }\end{array}$} & \multirow{2}{*}{$\begin{array}{l}\text { No. of } \\
\text { samples }\end{array}$} & \multicolumn{3}{|c|}{$\begin{array}{l}\text { Concentration } \\
(\mathrm{pCi} / \mathrm{L})\end{array}$} & \multirow{2}{*}{$\begin{array}{l}\text { DCG } \\
(\%)\end{array}$} & \multirow{2}{*}{$\begin{array}{l}\text { Standard } \\
\text { deviation }\end{array}$} \\
\hline & & $\operatorname{Max}$ & Min & $\mathrm{Av}$ & & \\
\hline \multicolumn{7}{|c|}{ Little Beaver Creek } \\
\hline RW7 & 12 & 88 & $<22$ & $<27.5$ & $<0.028$ & 19.1 \\
\hline RW8 & 48 & 71 & $<22$ & $<23.4$ & $<0.023$ & 7.2 \\
\hline RW12 & 12 & $<24$ & $<2$ & $<22.2$ & $<0.022$ & 0.6 \\
\hline \multicolumn{7}{|c|}{ Big Beaver Creek } \\
\hline RW5 & 12 & $<22$ & $<22$ & $<22.0$ & $<0.022$ & 0.0 \\
\hline RW13 & 12 & 52 & $<22$ & $<24.5$ & $<0.025$ & 8.7 \\
\hline \multicolumn{7}{|c|}{ Big Run Creek } \\
\hline RW2 & 12 & 48 & $<22$ & $<24.2$ & $<0.024$ & 7.5 \\
\hline RW3 & 12 & $<22$ & $<22$ & $<22.0$ & $<0.022$ & 0.0 \\
\hline RW33 & 12 & $<22$ & $<22$ & $<22.0$ & $<0.022$ & 0.0 \\
\hline \multicolumn{7}{|c|}{ Scioto River } \\
\hline RW1 & 52 & $<24$ & $<22$ & $<21.8$ & $<0.022$ & 1.6 \\
\hline RW6 & 51 & $<24$ & $<22$ & $<22.0$ & $<0.022$ & 0.3 \\
\hline
\end{tabular}

Table 5.8. Gross beta radioactivity in water samples at Portsmouth for 1993

\begin{tabular}{|c|c|c|c|c|c|c|}
\hline \multirow{2}{*}{$\begin{array}{l}\text { Sample } \\
\text { location }\end{array}$} & \multirow{2}{*}{$\begin{array}{l}\text { No. of } \\
\text { samples }\end{array}$} & \multicolumn{3}{|c|}{$\begin{array}{l}\text { Concentration } \\
(\mathrm{pCi} / \mathrm{L})\end{array}$} & \multirow{2}{*}{$\begin{array}{c}\mathrm{DCG}^{a} \\
(\%)\end{array}$} & \multirow{2}{*}{$\begin{array}{l}\text { Standard } \\
\text { deviation }\end{array}$} \\
\hline & & $\operatorname{Max}$ & Min & Av & & \\
\hline \multicolumn{7}{|c|}{ Little Beaver Creek } \\
\hline RW7 & 12 & 88 & $<10$ & $<22.8$ & NA & 21.6 \\
\hline RW8 & 48 & 61 & $<10$ & $<14.4$ & NA & 8.6 \\
\hline RW12 & 12 & $<12$ & $<11$ & $<11.3$ & NA & 0.5 \\
\hline \multicolumn{7}{|c|}{ Big Beaver Creek } \\
\hline RW5 & 12 & 35 & $<10$ & $<14.1$ & NA & 7.0 \\
\hline RW13 & 12 & 47 & $<11$ & $<16.0$ & NA & 10.3 \\
\hline \multicolumn{7}{|c|}{ Big Run Creek } \\
\hline RW2 & 12 & 18 & $<11$ & $<12.2$ & NA & 1.9 \\
\hline RW3 & 12 & $<19$ & $<11$ & $<12.8$ & NA & 2.5 \\
\hline RW33 & 12 & $<18$ & $<10$ & $<11.9$ & NA & 2.1 \\
\hline \multicolumn{7}{|c|}{ Scioto River } \\
\hline RW1 & 52 & $<45$ & $<8$ & $<12.2$ & NA & 4.9 \\
\hline RW6 & 51 & 31 & $<10$ & $<11.9$ & NA & 3.2 \\
\hline
\end{tabular}

${ }^{a}$ DCGs are radionuclide specific and are not applicable (NA) to gross beta activity. 
standard for beta emitters is equivalent to $900 \mathrm{pCi} / \mathrm{L}$. Gross beta activity in RW samples (Table 5.8) is dominated by the ${ }^{99} \mathrm{Tc}$ contribution.

Results of fluoride and phosphate analyses of Scioto River RW samples indicate no significant difference between upstream and downstream concentrations of either chemical. All analytical results for both chemicals were equal to or less than $0.5 \mathrm{mg} / \mathrm{L}$, with the exception of one phosphate analysis from RW1 $(0.9 \mathrm{mg} / \mathrm{L})$.

\section{SEDIMENT}

Receiving stream sediment sampling at Portsmouth is conducted twice a year to monitor for potential radionuclide accumulation from surface water discharges. The 1993 fall-quarter sediment samples were analyzed for 23 nonradiological parameters in an effort to further characterize the impact of Portsmouth surface water discharges on local streams. Stream sediment sampling locations are shown in Fig. 5.10.

\section{Program History}

Portsmouth has always found minor on-site radiological contamination in sediments downstream of the now dismantled X-701B wastewater treatment facility. Historically, the primary purpose of the sediment sampling program was to collect data regarding radiological contamination in those sediments so that remedial measures could be implemented if deemed necessary.

Until November 1988, wastewater from decontamination and uranium recovery operations was treated at the $\mathrm{X}$-701B wastewater treatment facility prior to discharge to Little Beaver Creek via the east drainage ditch (also referred to as NPDES outfall 001). Until it was taken out of service in 1988, X-701B was the main source of radiological discharges to surface water from Portsmouth. Some of the radionuclides discharged from X-701B were caught in the holding pond at the end of the east drainage ditch. These residual radionuclides are believed to be the source of current radiological discharges from this outfall (see Section 4) and of the uranium and technetium in sediments in Little Beaver Creek.

ORNL-DWG 87M-10318R4

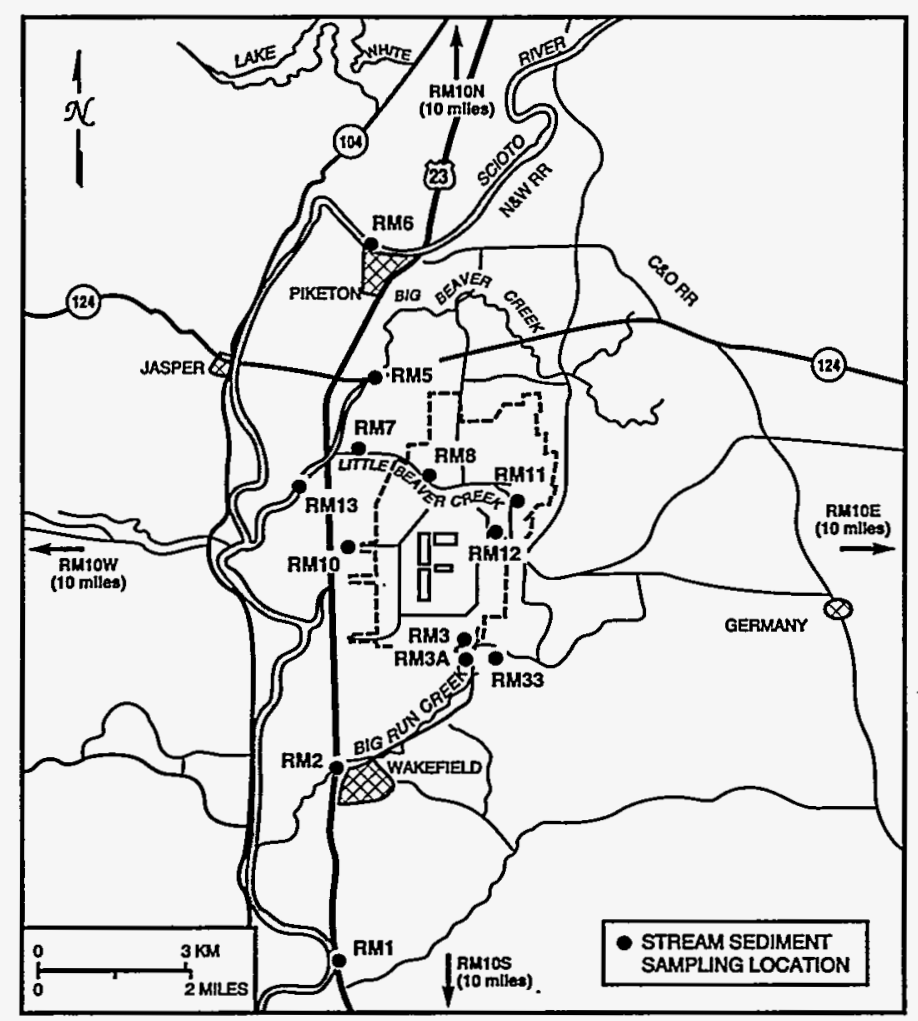

Fig. 5.10. Stream sediment sampling locations at Portsmouth. 
The smaller receiving streams around Portsmouth (i.e., the creeks, not the Scioto River) are narrow and become rapidly flowing streams during rainstorms. As a result, they tend to have sand and gravel bottoms covered with a thin layer of very fine sediment. This sediment is flushed downstream during each significant rainstorm. Although there is usually some contamination somewhere along the length of the Little Beaver Creek, both the extent and the location of contamination fluctuates widely.

\section{Sample Collection and Analytical Procedure}

Samples are collected semiannually from three major drainage ditches (i.e., the east and west ditches and the ditch downstream of the southwest holding pond), from upstream and downstream locations in the immediate receiving streams (Little Beaver Creek, Big Beaver Creek, and Big Run Creek), in the ultimate receiving stream (the Scioto River), and from four background locations. Samples are collected in new sample containers that are capped and then transported to the laboratory for analysis. Samples are analyzed routinely for total uranium concentrations, gross alpha activity, gross beta activity, and technetium beta activity. Samples are also analyzed for additional parameters on an as-requested basis.

\section{Results}

Results of analyses relating to 1993 sediment samples are summarized in the following paragraphs.

\section{Radiological}

As in past years, Portsmouth found minor radiological contamination in Little Beaver Creek sediments downstream of the east drainage ditch. Uranium and gross alpha activity were elevated only slightly at RM8 at about 7 to $10 \mu \mathrm{g} / \mathrm{g}$ and 20 to $30 \mathrm{pCi} / \mathrm{g}$, respectively, during both spring and fall samples. Technetium activity was present at 20 to $25 \mathrm{pCi} / \mathrm{g}$. At RM7, downstream of RM8, uranium and gross alpha concentrations were in the same range, but technetium activity fell to less than $1 \mathrm{pCi} / \mathrm{g}$ in the spring sample, increasing to 130 to $160 \mathrm{pCi} / \mathrm{g}$ in the fall sample.

No uranium contamination was found in Big Beaver Creek downstream of confluence with Little Beaver Creek. However, levels of technetium were present ( $23 \mathrm{pCi} / \mathrm{g}$ in the spring and $55 \mathrm{pCi} / \mathrm{g}$ in the fall). No radiological contamination was observed in sediments from Big Run Creek, the Scioto River, or the three outfalls themselves.

\section{Polychlorinated Biphenyls (PCBs)}

All sediment samples from the fall sampling event were analyzed for PCBs, and none were detected in any of the samples.

\section{Mercury}

All sediment samples from the fall sampling event were analyzed for mercury. A few of the samples contained mercury at slightly above the detection limit $(0.025 \mathrm{mg} / \mathrm{kg})$, the highest concentrations being $0.043 \mathrm{mg} / \mathrm{kg}$ from RM7 QA and 0.041 from RM13. Note that RM7 QA is a duplicate sample and that mercury was not detected in the primary sample from the same location. The third-highest mercury concentration $(0.035 \mathrm{mg} / \mathrm{kg})$ was found in sediments from RM1, which is in the Scioto River upstream from Portsmouth.

\section{RCRA Metals and Other Parameters}

Results of other parameters indicated no significant impact on the environment from Portsmouth discharges, although some apparent iron and zinc contamination was observed in creek sediments and unusually high concentrations of magnesium were noticed in Scioto River sediments. 


\section{SOIL}

Soil monitoring at Portsmouth is conducted to assess potential radionuclide accumulation. A summary of the results of the soil sampling program is presented in the following paragraphs.

\section{Sample Collection and Analytical Procedure}

Soil samples are analyzed to determine whether airborne emissions from Portsmouth are influencing the soil surrounding the site. Samples are collected twice a year from four geographically defined groups of sample locations. Group IA includes sample locations within or near the secured portion of the plant (Fig. 5.11, internal locations). Group I includes sample locations on or near the DOE reservation boundary (Fig. 5.12, on-site locations). Group II includes sample locations up to $5 \mathrm{~km}$ (3.1 miles) from the site (Fig. 5.13, off-site locations). Group $\mathrm{II}$ includes sample locations between 5 and $16 \mathrm{~km}$ (10 miles) from the site (Fig. 5.14, remote locations). In addition, four background sampling stations are located $16 \mathrm{~km}$ from the plant site. Groups I, II, and III are located near vegetation sampling points. Data generated from these samples are used to investigate correlations between potential soil contaminants and the uptake of those contaminants by vegetation.

From each sample point, a soil sample is collected, placed into a new container, covered, and transported to the laboratory for analysis. Soil sample analyses include total uranium concentration, total alpha activity, total beta activity, technetium beta activity, and chromium concentration. External samples of soil and vegetation are considered to be indicative of natural background concentrations and deposition of airborne radionuclides exclusively. Internal samples may be indicative of conditions resulting from past or present spills of radionuclide-bearing materials (e.g., decontamination solutions).

External soil samples are considered contaminated if more than $10 \mu \mathrm{g} / \mathrm{g}$ of uranium, $10 \mathrm{pCi} / \mathrm{g}$ of total alpha activity, or $1 \mathrm{pCi} / \mathrm{g}$ of technetium beta activity is detected. (The $1 \mathrm{pCi} / \mathrm{g}$ standard for technetium beta activity represents the analytical detection limit rather than a natural concentration.) Internal soil samples with levels of technetium beta activity of $10 \mathrm{pCi} / \mathrm{g}$ are classified as contaminated (this corresponds to $0.6 \mathrm{ppb}$ ). Normal area background levels of uranium range from 3 to $5 \mu \mathrm{g} / \mathrm{g}$ for internal and on-site samples and up to $10 \mu \mathrm{g} / \mathrm{g}$ for off-site and remote samples.

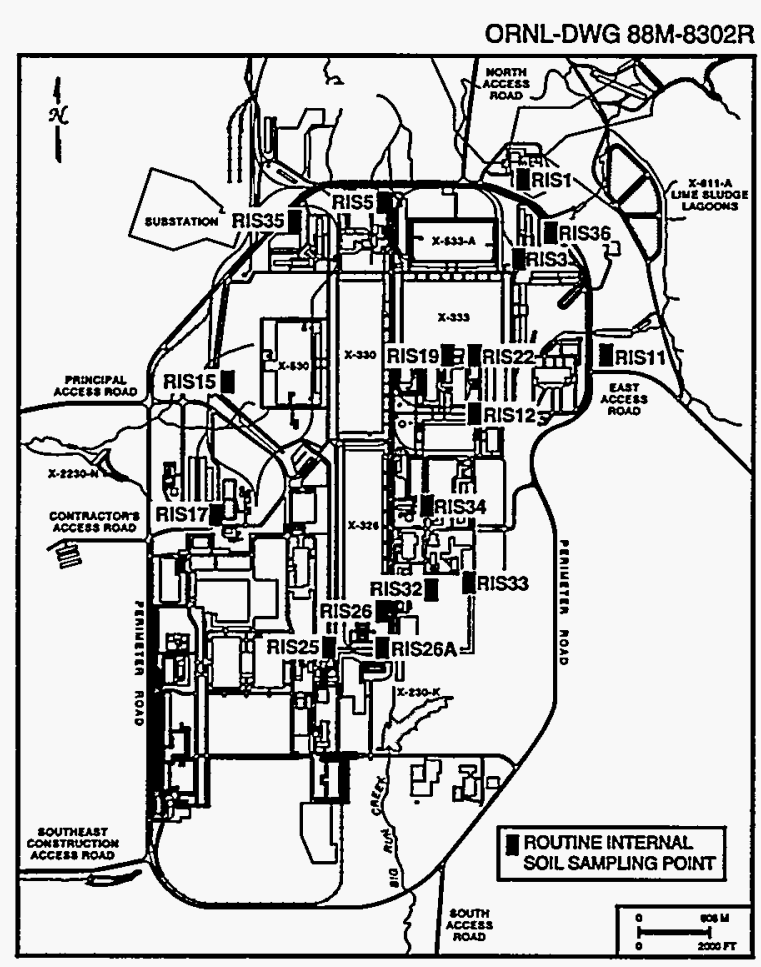

Fig. 5.11. Internal soil sampling locations at Portsmouth (Group IA). 


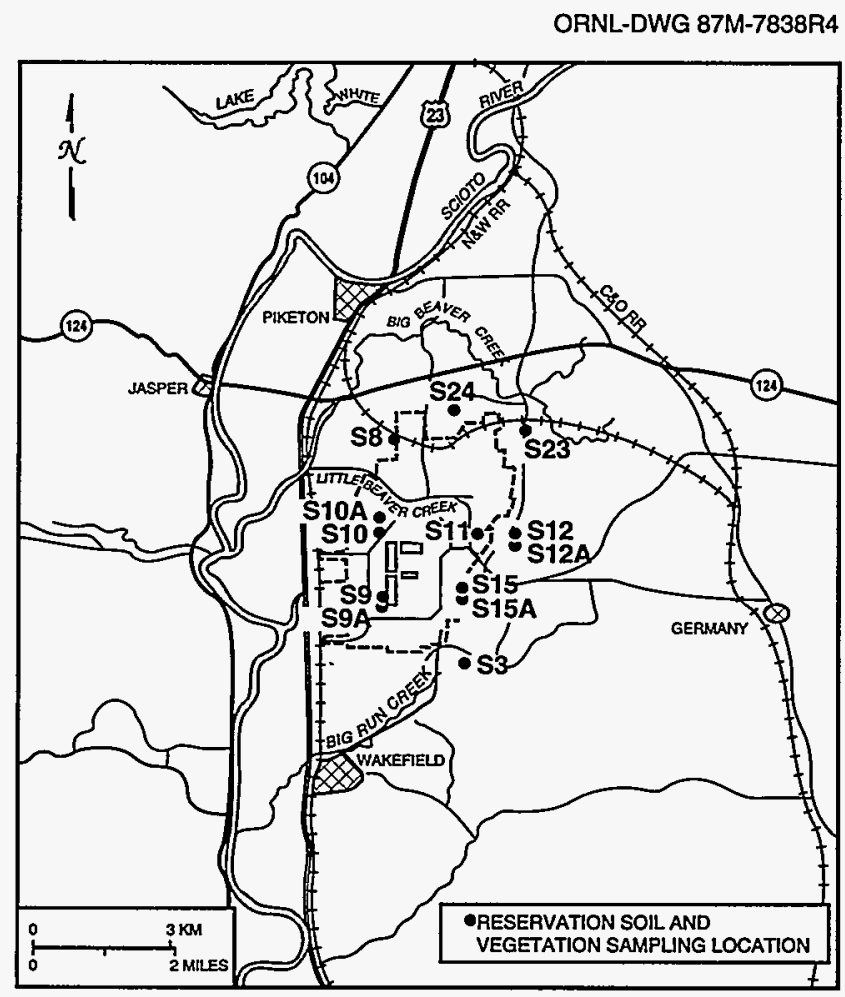

Fig. 5.12. On-site soil and vegetation sampling locations at Portsmouth (Group I).

ORNL-DWG 87M-7840R2

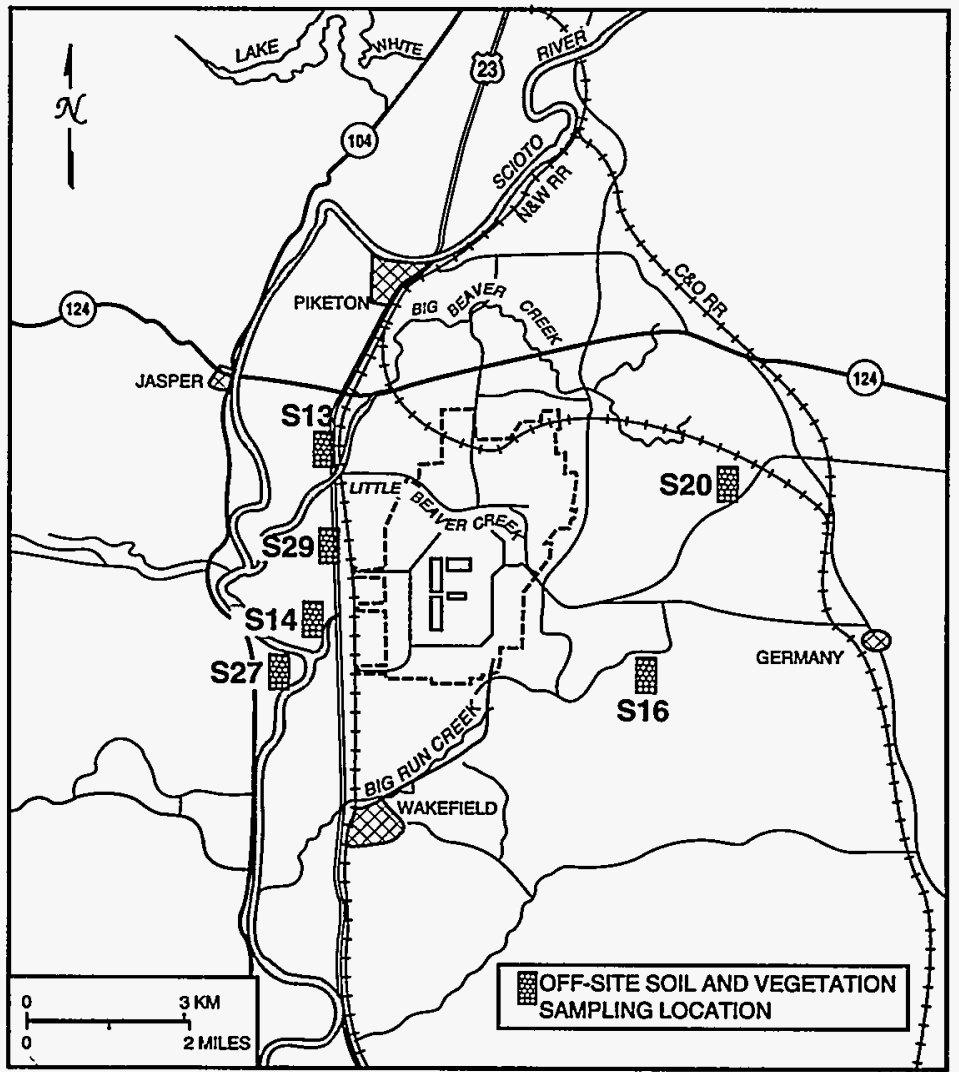

Fig. 5.13. Off-site soil and vegetation sampling locations for Portsmouth (Group II). 


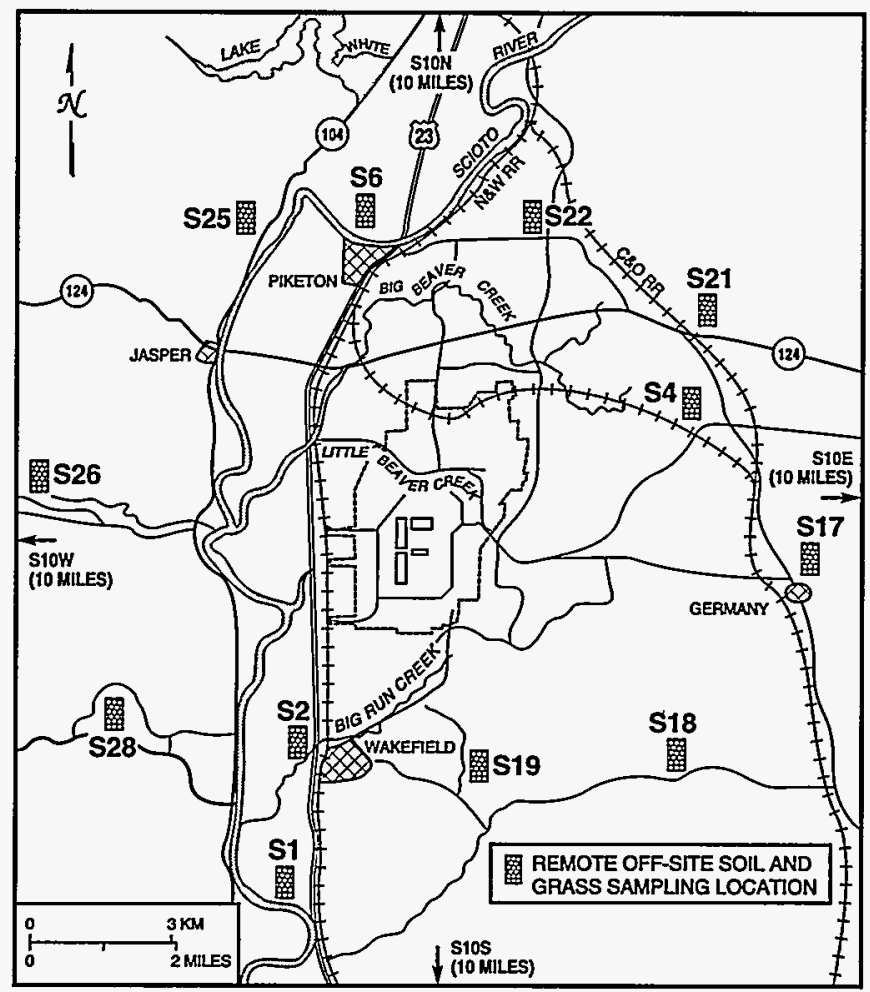

Fig. 5.14. Remote soil and vegetation sampling locations for Portsmouth (Group III).

Total background levels of alpha activity range from 3 to $6 \mathrm{pCi} / \mathrm{g}$. Background levels of technetium activity are less than $1 \mathrm{pCi} / \mathrm{g}$. The higher uranium content of the off-site and remote samples can be attributed to the shale and sandstone formations that crop out around the edges of the Portsmouth site. These formations are considerably older and have a higher natural uranium content than the clay bed beneath the site.

\section{Results}

Soil sample analyses revealed no significant environmental contamination. Analytical results obtained from all 35 external soil sample locations indicate that all were below contamination levels for radionuclides. They were also consistent with the 10-mile background samples for chromium concentrations.

Of the 32 internal samples, most were within contamination standards. Results from one sample point (RIS19, adjacent to the X-705 decontamination building) revealed technetium contamination (along with low uranium contamination). This area was known to be contaminated from historical small spills. Results of internal soil samples also revealed normal chromium concentrations, based on the 10-mile background samples, except for two locations (RIS3 and RIS36). These two locations are both immediately adjacent to and downwind from the X-633 cooling towers. A chromium-based corrosion inhibitor was used in the recirculating cooling water systems and is most likely the source of the chromium detected at these two locations.

\section{VEGETATION}

Portsmouth has conducted parallel vegetation and soil sampling programs since 1975. Vegetation (wide-blade grass typical of local cattle forage) and soil samples are collected semiannually from several locations in and around the Portsmouth site. The parallel programs allow for comparison of specific potential soil contaminants and vegetative uptake rates for those contaminants. 


\section{Sample Collection and Analytical Procedure}

Vegetation samples were collected from 31 off-site locations. These locations are divided into three sample groups. Group I includes sample points on or near the DOE reservation boundary (Fig. 5.12). Group II extends to $5 \mathrm{~km}$ ( 3 miles) from the site (Fig. 5.13). Group III extends to between 5 and $16 \mathrm{~km}$ ( 3 and 10 miles) from the site (Fig. 5.14). In addition, four background sampling stations are located $16 \mathrm{~km}$ (10 miles) from the site.

Samples of wide-blade grass are clipped above ground level; soil is excluded. Samples are placed into resealable plastic bags, transferred to the laboratory, and analyzed for total uranium concentration, technetium beta activity, and fluoride concentration.

\section{Results}

Results of vegetation samples for 1993, like the soil samples, revealed no significant environmental contamination. No uranium was detected in any of the vegetation samples, and all fluoride concentrations were well below the 30 to $40 \mu \mathrm{g} / \mathrm{g}$ levels, levels at which vegetative fluorides may begin to discolor the teeth of foraging cattle.

The majority of results revealed no detectable technetium. However, samples collected from four locations in Group I and three locations in Group II contained low levels of technetium. The Group I samples (all of which showed less than $1 \mathrm{pCi} / \mathrm{g}$ ) were all clustered on the east to southeast side of the plant. The Group II samples (only one of which exceejed $1 \mathrm{pCi} / \mathrm{g}$ ) were spread out along the west side of the plant. Furthermore, the location of the Group II sample with the highest concentration (2.1 pCi/g at S13) is farther from the facility than a location directly between the contaminated area and the plant (S8), where no technetium was detected. Moreover, no technetium was detected in the soil samples from S13. The results from these vegetative samples are not believed to be indicative of actual technetium contamination in the environment around Portsmouth.

\section{FOOD CROPS}

Radioactive contamination of crops may result from absorption of radioactive materials from the soil or from deposition of airborne contaminants. Since 1976, local farmers have voluntarily provided food crop samples to Portsmouth environmental surveillance personnel, who collect the samples and submit them to the laboratory for analysis.

\section{Sample Collection and Analytical Procedure}

Because of fluctuations in available crops, the selection of crops analyzed varies considerably from year to year (although corn and tomatoes are consistently available). Individual samples were obtained from local gardens and from gardens several kilometers from the plant boundary. Crops analyzed in 1993 included corn, tomatoes, apples, squash, cabbage, beans, peaches, pears, okra, grapes, cucumbers, and cherries.

Food crop samples are collected in resealable plastic bags, delivered to the laboratory, weighed, and dried before analysis. Results of analyses are reported as wet-weight concentrations to reflect the typical condition of the produce upon consumption. Food crops are analyzed for total uranium concentration and technetium beta activity. If uranium concentrations exceed a threshold value, gross alpha and gross beta analyses are also performed.

Environmental surveillance personnel obtain the results of food crop analyses from the laboratory, and food crop donors are notified in writing of the results. Resampling is conducted if analytical results are significantly higher than expected background levels.

\section{Results}

No detectable levels of uranium or technetium were found in the 33 samples collected in 1993. 


\section{FISH}

In 1983, Portsmouth initiated a fish sampling program in the Scioto River and in local creeks downstream of the site. These creeks are of particular concern because flow rates are typically low and dilution of plant effluents is minimal.

\section{Sample Collection and Analytical Procedure}

Fish are collected from the receiving streams and larger outfalls surrounding Portsmouth. During 1993, the streams sampled included several plant outfalls not accessible to the public (Little Beaver Creek and the Scioto River). Recreational activities relating to these streams are limited to occasional sport fishing, which greatly limits the impact of contamination levels on humans. In 1993, samples were analyzed for total concentrations of uranium, chromium, and PCBs, as well as gross alpha, gross beta, and technetium beta activity.

\section{Results}

No detectable levels of uranium, chromium, or radioactivity were found in any of the fish samples taken around Portsmouth in 1993. PCB concentrations in fish taken from Little Beaver Creek ranged from undetectable to $3.2 \mathrm{ppm}$, and analysis of two fish samples from Big Beaver Creek revealed barely detectable PCB concentrations $(0.2 \mathrm{ppm}$ and $0.3 \mathrm{ppm}$, against a limit of detection of $0.2 \mathrm{ppm})$. This is consistent with analysis of previous fish samples and is a lingering effect of historical (pre-1980) PCB spills. The Food and Drug Administration standard for PCBs in food fish is $2 \mathrm{ppm}$.

\section{TERRESTRIAL WILDLIFE}

Occasionally, collisions between automobiles and wildlife occur within the reservation boundaries, creating an opportunity for animal tissues to be collected and examined. In 1993, however, no suitable animal tissues were collected for analysis. 


\title{
6. Dose
}

\begin{abstract}
Potential impacts on human health from Portsmouth operations are calculated based on environmental monitoring and surveillance data. For 1993, the maximum potential effective dose equivalent that an individual living off-site could receive from radiological releases from the Portsmouth plant is $0.91 \mathrm{mrem}$. This potential dose would be well below the $10 \mathrm{mrem} / \mathrm{year}$ limit set by the U.S. Environmental Protection Agency, the 100 mrem/year limit set by the Department of Energy, and the approximate $300 \mathrm{mrem} / \mathrm{year}$ dose the average person in the United States receives from natural sources of radiation. Chemical releases were also well below applicable standards, and dose calculations show that any potential chemical doses to the public would be minute and would not have any adverse health effects.
\end{abstract}

\section{INTRODUCTION}

Previous sections of this report characterize and quantify radiological and chemical releases from Portsmouth Gaseous Diffusion Plant (Portsmouth) operations during 1993 (Section 4) and the direct impacts on the surrounding environment (Section 5). This section evaluates the potential impacts (i.e., dose) on human health based on the data presented in sections 4 and 5 .

\section{APPLICABLE REGULATIONS}

\section{Radiological Regulations}

Airborne discharges of radionuclides from U.S. Department of Energy (DOE) facilities are regulated by the U.S. Environmental Protection Agency (USEPA) under the Clean Air Act and the National Emission Standards for Hazardous Air Pollutants (NESHAP). These regulations set an annual dose limit of $10 \mathrm{mrem} / \mathrm{year}$ to any member of the public as a result of airborne releases from DOE nuclear facilities, as well as setting performance standards for demonstrating compliance with the dose limit.

Gaseous radionuclide discharges are also regulated, along with all other atmospheric pollutants, under the Ohio Permit-To-Operate regulations. However, Ohio does not yet have any standards governing radionuclide emission limits and therefore defers to the federal NESHAP regulations.

In addition to these outside authorities, DOE regulates radionuclide emissions to all environmental media through DOE orders 5400.1, General Environmental Protection Program, and 5400.5, Radiation Protection of the Public and the Environment. DOE Order 5400.5 sets an annual dose limit of $100 \mathrm{mrem} / \mathrm{year}$ to any member of the public. Unlike the NESHAP limit, the DOE limit includes all radionuclide releases from a facility. Furthermore, DOE Order 5400.5 limits the absorbed dose to aquatic biota from liquid discharges to less than $1 \mathrm{rad} /$ day.

\section{Chemical Regulations}

Discharges to the atmosphere are regulated under the Ohio Permit-To-Operate regulations issued under the state equivalent of the Clean Air Act. Enforceable limits on emissions in these permits are based on maintaining normal ambient air concentrations within ambient air quality standards (which are not directly enforceable on individual sources).

Liquid plant effluents are regulated by the National Pollutant Discharge Elimination System (NPDES) permit issued under the Clean Water Act. Enforceable limits in the permit are based on maintaining appropriate water quality in receiving streams. 


\section{DOSE CALCULATION}

Small quantities of radionuclides were released to the environment from Portsmouth operations during 1993. This section summarizes estimates of the potential consequences of the releases and describes the methods used to make the estimates.

\section{Radiological Dose Calculation}

\section{Terminology}

Most consequences associated with radionuclides released to the environment are caused by interactions between human tissue and various types of radiation emitted by the radionuclides. These interactions involve the transfer of energy from radiation to tissue, possibly resulting in tissue damage. Radiation may come from radionuclides outside the body (in or on environmental media or objects) or from radionuclides deposited inside the body (by inhalation, ingestion, and, in a few cases, absorption through the skin). Exposures to radiation from radionuclides outside the body are called external exposures; exposures to radiation from radionuclides inside the body are called internal exposures. This distinction is important because external exposure occurs only as long as a person is near the external radionuclide; simply leaving the area of the source will stop the exposure. Internal exposure continues as long as the radionuclide remains inside the body.

A number of specialized units have been defined for characterizing exposures to ionizing radiation. Because the damage associated with such exposures results primarily from the deposition of radiant energy in tissue, the units are defined in terms of the amount of incident radiant energy absorbed by tissue and of the biological consequences of that absorbed energy. These units include the following:

- Absorbed dose-a physical quantity that defines the amount of incident radiant energy absorbed per unit mass of an irradiated material; its unit of measure is the rad. The absorbed dose depends on the type and energy of the incident radiation and on the atomic number of the absorbing material.

- Dose equivalent-a quantity that expresses the biological effectiveness of an absorbed dose in a specified human organ or tissue; its unit of measure is the rem. The dose equivalent is numerically equal to the absorbed dose multiplied by modifying factors that relate the absorbed dose to biological effects. In this report, the term "dose equivalent" is often shortened to "dose."

- Effective dose equivalent ( $E D E$ ) - a risk-equivalent dose equivalent that can be used to estimate health-effects risks to exposed persons; it is a weighted sum of dose equivalents to specified organs. The weighing factors and identification of these specific organs have been published by the International Commission on Radiological Protection (ICRP 1977, ICRP 1978).

- Committed (effective) dose equivalent (CEDE)—-the total (effective) dose equivalent that will be received over a specified time period (in this document calculations are based on a 50-year period) because of radionuclides taken into the body during the current year.

- Collective committed (effective) dose equivalent-the sum of committed (effective) dose equivalents to all individuals in an exposed population. The unit of measure is the person-rem. The collective dose is also frequently called the "population dose."

- Dose conversion factor - the dose equivalent received from exposure to a unit quantity of a radionuclide by a specific exposure pathway. Two types of dose conversion factors exist. One type gives the committed dose equivalent (rem) resulting from intake (by inhalation and ingestion) of a unit activity (1.0 $\mu \mathrm{Ci})$ of a radionuclide. The second type gives the dose equivalent rate (mrem) per unit activity $(1.0 \mu \mathrm{Ci})$ of a radionuclide in a unit $\left(\mathrm{cm}^{3}\right.$ or $\mathrm{cm}^{2}$ ) of an environmental compartment (air or ground surface).

\section{Dose Calculation for Airborne Radionuclides}

Characterizing the consequences of radionuclides released to the atmosphere during 1993 was accomplished by calculating EDEs to the maximally exposed person (a hypothetical individual who is assumed to reside at the most exposed point on the plant boundary) and to the entire population (approximately 918,506) residing within $80 \mathrm{~km}$ (50 miles) of the plant. Dose calculations were made using the Clean Air Act Assessment Package-88 
(CAP-88) of computer codes (Beres 1990), which was developed under sponsorship of the USEPA for use in demonstrating compliance with NESHAP concerning radionuclides [Title 40, Code of Federal Regulations, Part 61 (40 CFR 61), Subpart H]. This package contains the most recently approved version of the AIRDOS-EPA and DARTAB computer codes and of the ALLRAD88 radionuclide data file. The AIRDOS-EPA computer code implements a steady-state, Gaussian plume, atmospheric dispersion model to calculate concentrations of radionuclides in the air and on the ground; it uses Regulatory Guide 1.109 food-chain models to calculate radionuclide concentrations in foodstuffs (e.g., vegetables, meat, and milk) and subsequent intakes by individuals. The concentrations and human intakes are used by the USEPA's latest version of the DARTAB computer code to calculate EDEs to humans from radionuclides released to the atmosphere. The dose calculations use the dose conversion factors contained in the ALLRAD88 data file.

Radionuclide release data were modeled for three release points. The radionuclide release inventory is detailed in Section 4.

Meteorological data used in the calculations consisted of joint frequency distributions of wind direction, wind speed, and atmospheric stability that were prepared from data collected during 1993 at the 40-m station on the Portsmouth meteorological tower. Rainfall during 1993 was $88 \mathrm{~cm}$ (35 in.), the average air temperature was $12.8^{\circ} \mathrm{C}\left(55^{\circ} \mathrm{F}\right)$, and the average mixing layer height was $2000 \mathrm{~m}(6562 \mathrm{ft})$.

The dose calculations assumed that each person remained unprotected, at home (actually outside the house) during the entire year and obtained food according to the rural pattern defined in the NESHAP background documents (USEPA 1989b). This pattern specifies that $70 \%$ of the vegetables and produce, $44.2 \%$ of the meat, and $39.9 \%$ of the milk consumed by each person are produced in the local area (e.g., in a home garden). The remaining portion of each food is assumed to be produced within $80 \mathrm{~km}$ (50 miles) of Portsmouth. For collective EDE estimates, production of beef, milk, and crops within $80 \mathrm{~km}$ (50 miles) of Portsmouth was calculated using the state-specific production rates-provided with CAP-88.

\section{Dose Calculation for Waterborne Radionuclides}

Water is sampled at all plant outfalls and in the receiving streams. Sample results for the Scioto River show no significant difference in radionuclide concentrations between upstream and downstream locations (see Section 5). Nevertheless, a hypothetical dose was calculated using measured radionuclide discharges from plant outfalls and the average annual flow rate of the Scioto River. The hypothetical most exposed individual was assumed to drink $730 \mathrm{~L}$ (190 gal) of river water, eat $21 \mathrm{~kg}(46 \mathrm{lb})$ of fish caught in the Scioto River, swim for 27 hours in the river, boat for 105 hours on the river, and occupy the shoreline for 69 hours during the year. This is a very conservative exposure scenario because the Scioto River is not used for drinking water or for commercial or subsistence fishing downstream of Portsmouth. (About $76 \%$ of the hypothetical dose from liquid effluents is from drinking river water, and essentially all the remainder is from eating fish from the river.)

\section{Dose Calculation for Radionuclides in Other Environmental Media}

The CAP-88 computer codes calculate doses from ingestion of meat, milk, and vegetables containing radionuclides that were released to the atmosphere. Using the conservative food consumption pattern described in the previous sections, about $62 \%$ of the maximum individual EDE and $81 \%$ of the collective EDE result from ingestion of foodstuffs.

\section{Calculation of Radiological Dose to Aquatic Biota}

DOE Order 5400.5, Chapter II, sets an absorbed dose rate limit of $1 \mathrm{rad} /$ day to native aquatic organisms. To demonstrate compliance with this limit, absorbed dose rates to crustacea, mollusks, and fish were calculated using the CRITR2 computer code and measured (annual average) radionuclide concentrations in the Scioto River. CRITR2 estimates dose rates from internally deposited radionuclides, from immersion in water, and from sediment irradiation (Baker and Soldat 1993). 


\section{Chemical Dose Calculation}

Varying amounts of chemicals were released to the environment from operations at Portsmouth during 1993. This section contains estimates of potential human exposure to these chemicals and compares the exposures to acceptable levels of exposure as defined by federal standards and regulations.

\section{Terminology}

Terms pertinent to discussion of chemical exposure include the following:

- Acceptable daily intake (ADI)-intake of a chemical (measured in milligrams per day) that is not anticipated to result in any adverse health effects over a lifetime of exposure. ADIs are calculated from several different federal standards and regulations.

- Ambient air quality standard (AAQS) - national or state standard for maximum concentration of an airborne pollutant that is not expected to adversely affect the public health (primary AAQS) or the public welfare (secondary AAQS).

- Calculated daily intake (CDI)-intake of a chemical (expressed in milligrams per day) from drinking $2 \mathrm{~L}$ $(-2 \mathrm{qt})$ of surface water per day.

- Maximum contaminant level-maximum concentration legally allowable in drinking water under USEPA national interim primary and national primary drinking water regulations that apply to all community or public water systems.

- Maximum contaminant level goal-maximum concentration desirable in drinking water. USEPA national secondary drinking water regulations that apply to public water systems.

- $\quad N P D E S$ - permit program that includes effluent standards, monitoring requirements, and conditions for discharge.

- Reference dose - an estimate of the daily exposure to the human population, including sensitive individuals, that is likely to be without an appreciable risk of harmful effects during a lifetime.

\section{Dose Calculation for Airborne Chemicals}

Since the early 1980s, Portsmouth has voluntarily monitored and tracked ambient concentrations of gaseous fluorides in the atmosphere for comparison to the AAQS. Because neither the USEPA nor the Ohio EPA have established an AAQS for gaseous fluorides, the AAQSs set by the states of Tennessee and Kentucky are used.

\section{Dose Calculation for Waterborne Chemicals}

The USEPA has set ADI standards for some chemicals in the form of maximum contaminant levels and maximum contaminant level goals (in milligrams per liter), which were converted to ADI values by multiplying by the average daily adult water intake of $2 \mathrm{~L}(-2 \mathrm{qt})$. Drinking water regulations and standards apply to community or public water systems and thus are conservative when applied to surface water.

For chemicals for which maximum contaminant levels or maximum contaminant level goals were not available, ADIs were calculated from oral reference doses. These values are available from the USEPA Integrated Risk Information System (USEPA 1991). For noncarcinogenic chemicals, daily exposure to the reference dose (in milligrams per kilograms per day) should result in no adverse effect over a lifetime. ADIs were calculated from reference doses by multiplying by $70 \mathrm{~kg}$, the average human body weight.

Outfalls are not readily accessible to the general public; therefore, ingestion of water directly from outfalls is unlikely. Although it is possible for a member of the public to ingest water from either Big Beaver Creek or Big Run Creek, both of these water bodies run through active agricultural operations (i.e., farms and cattle pastures) along their entire length between Portsmouth and the Scioto River and are classified as unsuitable for use as potable water sources because of agricultural runoff. Consequently, the first realistic location for a member of the public to be routinely exposed to liquid discharges is the Scioto River. In fact, there are no identified drinking water intakes in the Scioto River downstream of Portsmouth either.

\section{6-4 Dose}


Sampling data for eight metals and two organic chemicals are available for NPDES outfall stations. (Not all chemicals were measured at each outfall.) Annual average values of the sampling data (in micrograms per liter) were multiplied by $2 \mathrm{~L}$ to estimate routine daily intake levels. Much of the sampling data for individual chemicals were reported as "less-than" $(<)$ values, indicating that concentrations were below the limits of detection of the analytical methods used. Because average sample concentrations were reported as less-than values, the CDIs are also reported as less-than values. The CDIs were compared with the ADIs to establish whether ingestion of water could result in an exposure above the ADI. CDI/ADI ratios of less than 1 indicate an acceptable level of risk, while CDI/ADI ratios greater than 1 could indicate an unacceptable risk or the need for further study.

\section{Calculation of Direct Exposure to Chemicals}

Direct exposure to chemicals does not represent a likely pathway of exposure at the Portsmouth facility. For airborne releases, concentrations off-site are too small to present problems through the skin exposure pathway. For water releases, outfalls are generally located within areas of the DOE facility that are not readily accessible to the general public. Although exposures for consumption of drinking water at the discharge sites were calculated, public exposure to water from the area of the discharge is highly unlikely.

\section{DOSE CALCULATION RESULTS}

\section{Radiological Dose Results}

\section{Airborne Radionuclide Results}

The maximum potential EDE to an off-site individual from 1993 radiological releases from Portsmouth is 0.9 mrem (Table 6.1), which is well below the 10-mrem NESHAP limit applicable to Portsmouth and the approximate 300-mrem dose that the average individual in the United States receives from natural sources of radiation. It is unlikely that any one person would be exposed to maximum doses from both gaseous and liquid effluents because the points of maximum exposure are on opposite sides of the plant. Furthermore, no one is known to draw drinking water from the Scioto River downstream of the plant.

Table 6.1. Summary of estimated committed effective dose equivalent (CEDE) to an adult at locations of maximum exposure

\begin{tabular}{cll}
\hline $\begin{array}{c}\text { Emission } \\
\text { pathway }\end{array}$ & Location & $\begin{array}{c}\text { CEDE } \\
\text { (mrem) }\end{array}$ \\
\hline Gaseous releases & $1770 \mathrm{~m} \mathrm{ENE}$ & 0.9 \\
Aqueous releases & Scioto River & 0.007 \\
\hline
\end{tabular}

The collective EDE to the entire population around Portsmouth was 11.6 person-rem, which is a minute fraction of the approximate 276,000 person-rem that this population received from natural sources of radiation during 1993. The collective EDE to the nearest community, Piketon, was calculated to be approximately 0.4 person-rem.

\section{Waterborne Radionuclide Results}

If the Scioto River were used for drinking water, fishing, and recreation, an annual EDE of 0.007 mrem could have been received from radionuclides released to surface water.

In the Scioto River, potential dose rates to aquatic biota were $8 \times 10^{-8} \mathrm{rad} /$ day to fish, $4 \times 10^{-7} \mathrm{rad} /$ day to crustacea, and $3 \times 10^{-7} \mathrm{rad} /$ day to muskrats. These results indicate that the aquatic biota did not receive an absorbed dose of greater than $1 \mathrm{rad} /$ day during 1993. 


\section{Chemical Dose Results}

\section{Airborne Chemical Results}

During 1993, all of the measured gaseous fluoride concentrations in ambient air were within applicable Tennessee and Kentucky AAQSs.

\section{Waterborne Chemical Results}

Three CDI/ADI ratios, as measured at the plant outfalls, equaled or exceeded 1 during 1993. Two of these three ratios were located at internal NPDES outfalls (outfalls 602 and 606), which discharge to other on-site wastewater treatment facilities. After mixing with the Scioto River is taken into account, all of the CDI/ADI ratios calculated for 1993 were well under 1.

The $1993 \mathrm{CDI} / \mathrm{ADI}$ ratios greater than 1 are summarized in Table 6.2. The CDI/ADI ratio for iron at outfall 002, which discharges to Big Run Creek, was 5.3 during 1993. Flow from outfall 002 averaged slightly less than 1.4 million liters per day during 1993, compared with the Scioto River's 12.7 billion liters per day. Consequently, this CDI/ADI ratio would have been reduced to less than 0.0006 by the time the discharge mixed with the river.

Table 6.2. Summary of CDUADI ratios exceeding 1 in 1993

\begin{tabular}{clc}
\hline Outfall & Chemical & CDIADI \\
\hline 002 & Iron & 5.3 \\
602 & Iron & 2.6 \\
606 & Trichloroethylene & 5.0 \\
\hline
\end{tabular}

The CDI/ADI ratio for iron from outfall 602 was also greater than 1 . Outfall 602 discharges through outfall 002 however, so its iron contribution is incorporated in the ratio for that outfall. Finally, the CDI/ADI ratio for trichloroethylene at outfall 606 exceeded 1 . Outfall 606 discharges, at an average rate of less than 12 thousand liters per day, through outfall 003 , which has an average flow of over 1 million liters per day. As a result, this CDI/ADI ratio would be reduced to 0.05 before it leaves the site. 


\section{Groundwater}

\section{Abstract}

The purpose of groundwater monitoring at Portsmouth is to characterize the hydrogeology and monitor groundwater quality at the Portsmouth plant and its environs. More than $\mathbf{5 0 0}$ monitoring wells are used to track the flow of groundwater and to measure any contaminants present both on- and off-site. Groundwater monitoring extends to surface water that receives direct input from groundwater sources. Off-site sampling is conducted to assess the effects of Portsmouth operations on nearby public and residential water supplies.

\section{INTRODUCTION}

The purpose of the Groundwater Monitoring Program is to characterize the hydrogeology and monitor the groundwater quality at Portsmouth Gaseous Diffusion Plant (Portsmouth) and its environs. Groundwater monitoring activities conducted by the Environmental Restoration and Waste Management Division include surveillance monitoring and monitoring of (1) Resource Conservation and Recovery Act (RCRA) units, (2) solid waste disposal units, (3) special investigations or monitoring units, (4) groundwater treatment units, and (5) RCRA facility investigation (RFI) quadrant location units.

\section{GROUNDWATER HYDROLOGY}

A portion of rain accumulates as groundwater by soaking into the ground, infiltrating soil and rock. The accumulation of groundwater in pore spaces of sediments creates sources of usable water, which flows in response to external forces. Groundwater eventually reappears at the surface in springs, swamps, stream and river beds, or pumped wells. Thus, the primary input to groundwater is recharge from rainwater, and the output of groundwater is discharge to springs, swamps, rivers, streams, and wells.

Surface water percolates downward into soil through the pore spaces between sediment grains. The smaller the pore spaces, the slower the flow of water through pore spaces, and the slower the flow of water through pore spaces, the slower the flow of water through sediment. Permeability is the ease with which water moves through the pore spaces and cracks in a given material and is largely determined by the volume and size of the pore spaces and how well connected the pore spaces are.

As water infiltrates the earth, it travels down through the vadose, or unsaturated, zone. Here the pore spaces are filled partly with water and partly with air. Water moving down through the unsaturated zone will eventually reach the saturated zone, where the pore spaces are completely filled with water. The boundary between unsaturated and saturated zones is known as the water table, the elevation of which generally follows, in subtle form, the contour of the surface topography. Springs, swamps, and beds of streams and rivers are outcrops of the water table.

The unit of measurement for permeability most commonly used in the study of hydrology or hydrogeology is hydraulic conductivity, which indicates the speed (or velocity) at which groundwater flows through a particular kind of rock or soil. The water pressure at a particular location, called the hydraulic head, is for the most part a result of the elevation of the water table at that location. The hydraulic head varies from location to location because the elevation of the water table is not level but normally mimics the surface of the ground, although in a subdued fashion. Variations in the hydraulic head create a hydraulic gradient and are the driving force for movement of groundwater through the saturated zone. In addition to hydraulic conductivity, the actual groundwater velocity at a particular location depends on the hydraulic gradient and the porosity of the earth materials at that location.

The flow of groundwater and the position of the water table may be complicated by variations in the hydraulic conductivity. Because the materials the earth is composed of have greatly varying permeability, groundwater flowing through subsurface strata does not travel at a constant rate or without impediment. Strata that transmit water easily (such as those composed primarily of sand) are called aquifers, and strata that restrict water movement (such as clay and shale layers) are called aquitards. An aquifer with an aquitard lying above and below it is a confined aquifer. 
Groundwater moves through aquifers in a downgradient direction. Because hydraulic head is not solely a function of elevation, downgradient is not necessarily synonymous with downhill. The downgradient direction has a horizontal and a vertical component, just as a household drain moves wastewater both horizontally and vertically, seeking the lowest point of exit. Aquitards deflect groundwater movement just as drainpipe walls control the direction of wastewater movement. In an aquifer constrained by aquitards, such as horizontal clay layers, the downgradient direction tends to be more horizontal than vertical.

Water infiltrating surficial soils is the primary pathway for potentially hazardous substances to enter an aquifer. Substances placed in the soil may be dissolved in rainwater, which moves them downward through the unsaturated zone to the water table. The water then flows downgradient toward a discharge point.

Monitoring wells are used extensively to assess the effect of operations on groundwater quality, generally to determine the effect of a specific site on nearby groundwater quality. Wells positioned to intercept groundwater flowing away from a site are called downgradient wells, and wells placed to intercept groundwater before it flows under a site are called upgradient wells. Any contamination of downgradient wells not present in upgradient wells at a site may be assumed to be a product of that site. Wells are drilled to various depths in the saturated zone downgradient of the area to be monitored. At the screen zone, the well casing is perforated to allow water to enter the well. Thus, the screen zone refers to the zone of subsurface strata where water is being sampled by the well. Figure 7.1 illustrates the construction of a monitoring well and the relationship between the screen zone and water elevation for wells screened below the water table. Water rises in the well casing to equilibrate with the hydraulic head of the water surrounding the screen zone of the well. The elevation of the water in the well is measured to determine the hydraulic head of the water in the monitored zone. By comparing water levels in adjacent wells screened in the same zone, the hydraulic gradient can be determined and thus the horizontal direction of groundwater flow can be predicted. Only wells screened in the same zones are considered when determining the horizontal gradient; wells screened above and below an aquitard can have different hydraulic heads, defining a vertical gradient.

Vertical groundwater movement is controlled by

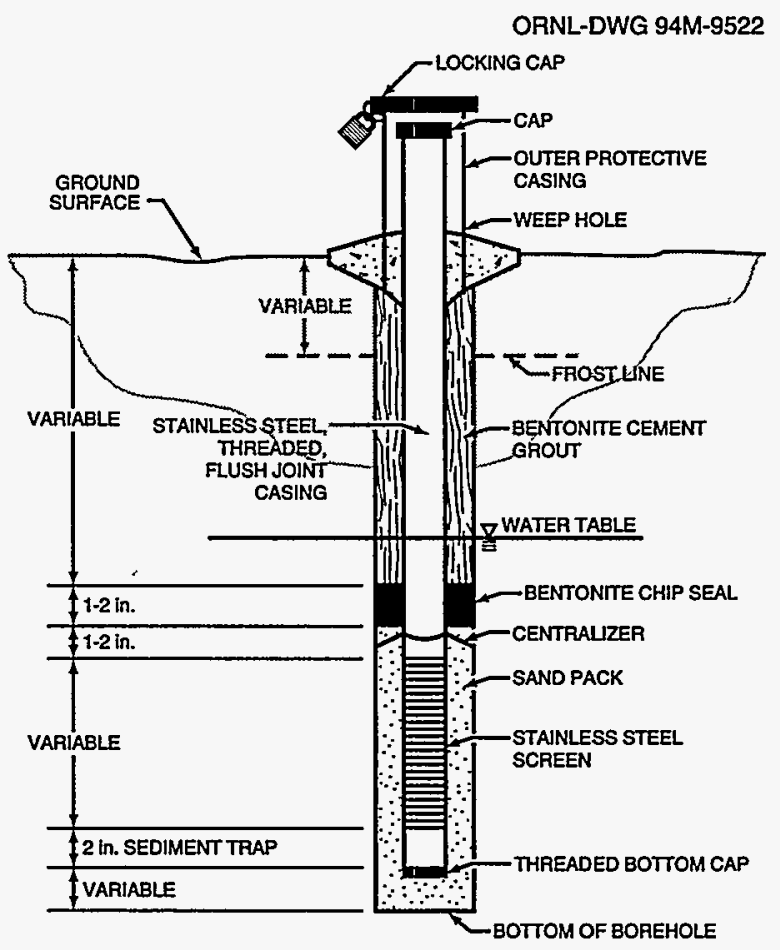

Fig. 7.1. Typical monitoring well construction. the hydraulic conductivity of the aquitards and the relative difference in hydraulic head of the water on either side of an aquitard. Vertical gradients can be determined by comparing the water levels between adjacent wells screened on either side of an aquitard. If the water levels in deeper wells are higher than those in shallower wells, the vertical component of flow is upward. Conversely, if the water levels in deeper wells are lower than those in shallower wells, the vertical component of flow is downward.

Vertical and horizontal groundwater flow directions are determined in part by the permeability and continuity of geologic strata. To effectively monitor the movement of groundwater and any hazardous constituents it may contain, hydrogeologists at Portsmouth have undertaken many detailed studies of the geology of the strata beneath the site.

\section{GEOLOGICAL AND HYDROGEOLOGICAL SETTING}

Portsmouth is located near the northwestern boundary of the Appalachian Plateau physiographic province. The uppermost rock units in this region were deposited in an inland sea during the Paleozoic era. At the end of

\section{7-2 Groundwater}


the Paleozoic era (approximately 230 million years ago), the region was uplifted and gently folded to form a shallow basin that parallels the Appalachian Mountains. Subsequent erosion of the uplifted sediments produced the deeply dissected, knobby terrain that characterizes the region. Glaciation during the Pleistocene era ( 2 million to 25,000 years ago) affected this region by changing the directions of streams, causing lakes to form and filling in valleys with lake and river sediments.

\section{Topography}

Portsmouth occupies an upland area of southern Ohio with an average land surface elevation of $670 \mathrm{ft}$ above mean sea level. The plant site sits in a mile-wide abandoned river valley $130 \mathrm{ft}$ above the Scioto River to the west. (See Fig. 7.2).

The predominant landform in the site area is the relatively level, broad, filled valley, which is oriented north to south and is bounded on the east and west by deeply dissected ridges or low-lying hills. Another significant landform is the small valley formed by Little Beaver Creek; this creek flows in a northwesterly direction across the middle of the site, just north and east of the main industrialized area.

Other significant landforms consist of several small valleys formed by streams that have cut into the relatively level unconsolidated deposits under the Portsmouth site. One of these valleys is that of a northwestwardly flowing stream, the west drainage ditch, which is near the west-central area of the plant. Two more streams are located in the southern portion of the industrialized area. In the southeast portion of the site, a southerly flowing stream, Big Run Creek, is situated in a relatively broad, gently sloping valley. An unnamed southwesterly flowing stream in the southwest portion of the site has formed a narrow, steep-walled valley.

In much of the industrialized area of Portsmouth, the original topography was modified for construction of buildings and other facility components.

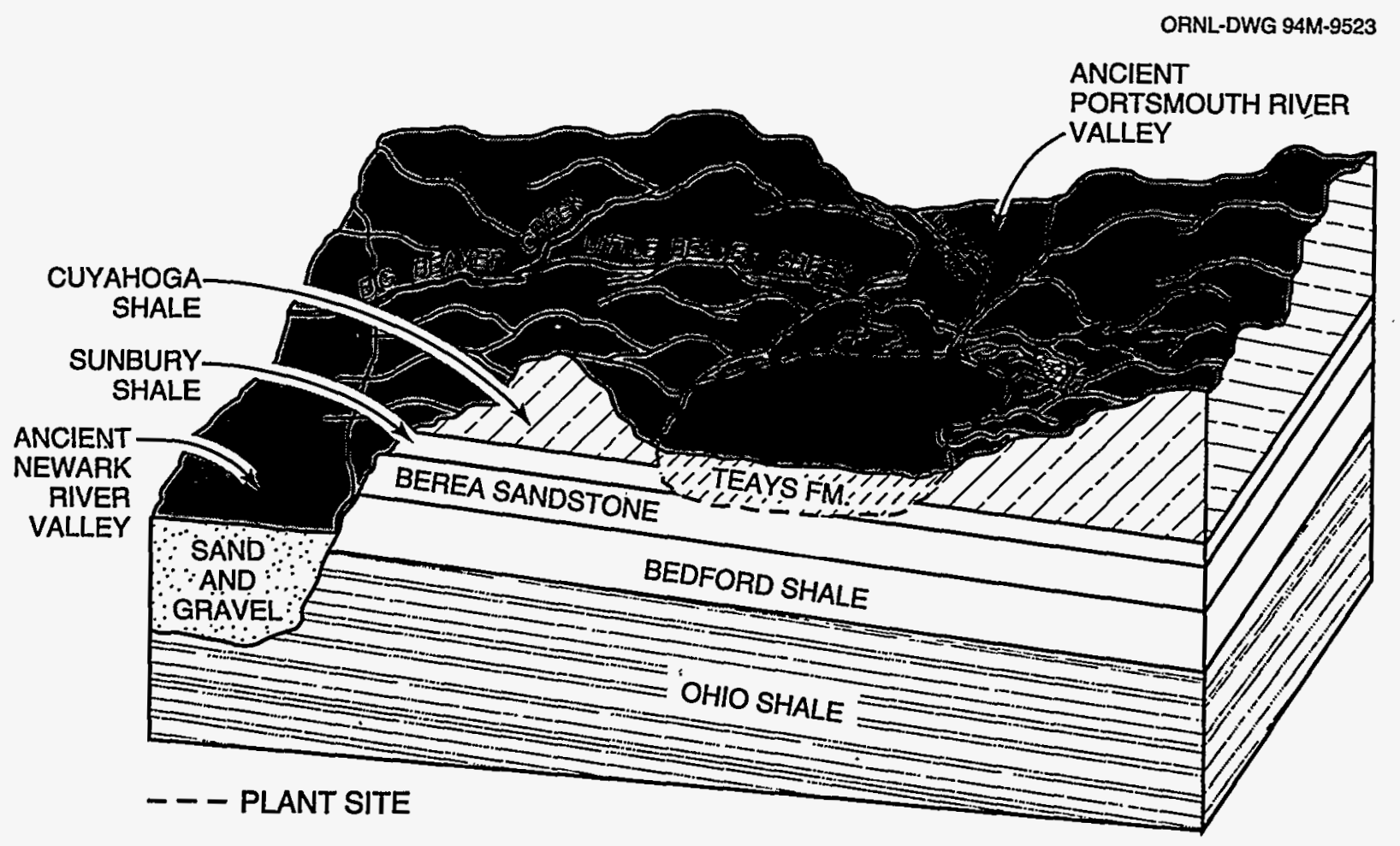

Fig. 7.2. Schematic cross section of the Portsmouth site. 


\section{Stratigraphy}

The surficial material over much of the industrialized area of Portsmouth is fill material removed from the higher elevations of the site. The material is composed of varying proportions of the unconsolidated geologic materials that are described in the following paragraphs (see Table 7.1).

Table 7.1. Stratigraphy in the vicinity of the Portsmouth facility

\begin{tabular}{lc}
\hline Geologic unit & \multicolumn{1}{c}{ Predominant lithology } \\
\hline Teays Formation & Unconsolidated \\
Minford member & upper: clay \\
& lower: silty clay and silt \\
Gallia member & silty sand, clay, sand, and gravel \\
& Bedrock \\
Cuyahoga Formation & shale \\
Sunbury Formation & shale \\
Berea Formation & sandstone \\
Bedford Formation & shale \\
Ohio Formation & shale \\
\hline
\end{tabular}

The geologic materials of the Portsmouth site consist of unconsolidated lacustrine (lake) and fluvial (river) deposits that overlie the regional consolidated bedrock. The unconsolidated deposits were deposited during the recent glaciation. Rather than being deposited directly by the glaciers, the deposits were formed in dammed, preexisting river valleys and in valleys created by glacial runoff, features peripheral to the glaciers themselves. The unconsolidated deposits beneath Portsmouth are not continuous with the unconsolidated deposits in the Scioto River valley to the west. A bedrock ridge forms the western valley wall that separates the two groups of unconsolidated deposits. The consolidated bedrock deposits formed in a broad, continental sea about 400 million years ago.

The unconsolidated Teays Formation (Fm.) consists of two members: the Minford clay and silt and the Gallia sand. The consolidated bedrock is composed of the Cuyahoga, Sunbury, Berea, and Bedford Fms. In the vicinity of Portsmouth, the Cuyahoga, Sunbury, and Bedford Fms. are predominantly shales, whereas the Berea Fm. is predominantly sandstone.

The Minford member of the Teays Fm. is a lacustrine deposit consisting of two distinct units: an upper clay unit with silt and sand and a lower silt unit composed of silty clay and very fine to fine-grained sand. Both units are continuous across Portsmouth. Across much of the facility, only the basal part of the clay unit is saturated, whereas the lower silt unit is usually completely saturated.

The Gallia member of the Teays Fm., commonly referred to as the Gallia sand, is a fluvial deposit underlying the Minford member at approximately $25 \mathrm{ft}$ below ground surface. The Gallia sand is discontinuous across the site and typically consists of red-brown, clayey, medium to coarse sand and gravel; it overlies bedrock and has a mean thickness of slightly more than $3 \mathrm{ft}$. The Gallia sand is usually poorly sorted, often containing silt and clay as well as numerous pebble-sized rock fragments. The Gallia sand is commonly absent near bedrock highs, such as the bedrock valley walls. The coarser sands and gravels usually occur near the base of the unit and were deposited as point bar and/or channel lag deposits. Contact between the Minford and Gallia members varies from gradational to sharp.

The Cuyahoga Fm., commonly referred to as the Cuyahoga shale, is the uppermost bedrock formation in the geographic area and is a moderately hard, thinly laminated shale with numerous sandstone laminations. The Fm. is not found beneath the industrial portion of Portsmouth but does form hills surrounding the facility.

\section{7-4 Groundwater}


The Sunbury Fm., commonly referred to as the Sunbury shale, is the uppermost bedrock formation (where present) beneath the industrial portion of Portsmouth. The unit is composed of a competent, black, carbonaceous, fissile shale that is approximately $20 \mathrm{ft}$ thick on the eastern portion of the facility and is absent on the western portion.

The Berea Fm., commonly referred to as the Berea sandstone, is continuous beneath the industrial portion of Portsmouth. The Berea sandstone underlies the Sunbury shale on the eastern portion of the facility and underlies the unconsolidated Minford and Gallia members of the Teays Fm. on the western portion of the facility. The Berea sandstone is approximately $30 \mathrm{ft}$ thick. A thin zone (1 to $3 \mathrm{in}$.) of sulfide mineralization occurs at the interface between the Sunbury shale and the Berea sandstone. The upper portion of the Berea Fm., approximately $20 \mathrm{ft}$ thick, is composed of a light-gray, hard, thickly bedded, fine-grained sandstone; the lower portion, approximately $10 \mathrm{ft}$ thick, has numerous interlayered shale laminations and is similar to the underlying Bedford Fm.

The Bedford Fm., commonly referred to as the Bedford shale, is continuous beneath Portsmouth and is also found everywhere beneath the Berea sandstone. The formation averages $100 \mathrm{ft}$ in thickness and consists of thinly bedded shale with interbeds and laminations of hard, gray, fine-grained sandstone and siltstone. In three boreholes that penetrated the Bedford, the sandstone interbeds at $570 \mathrm{ft}$ above the national geodetic vertical datum of 1929 (NGVD) were saturated with oil.

\section{Geologic History}

Prior to glaciation, the major drainage system in southern Ohio was the Teays River system. The Teays flowed northwest and passed about $4.8 \mathrm{~km}$ ( 3 miles) north of the area now occupied by Portsmouth. Immediately north of the plant site, Big Beaver Creek occupies a portion of the valley of the extinct Teays River.

The Portsmouth River, a tributary of the Teays, flowed north across the area that is now occupied by Portsmouth. In that same area, the Portsmouth River eroded a valley through the Cuyahoga shale and the Sunbury shale and in localized areas may have eroded into the Berea sandstone. The Sunbury was eroded into a wedge that diminishes to the west and exposes the Berea bedrock on the western half of the site. As the Portsmouth River meandered through the valley, sand and gravel were deposited; these fluvial deposits formed the Gallia member of the Teays Fm. Subsequently, an advancing glacier blocked the northwestward flow of the Teays River, and a glacial lake, Lake Tight, filled the valleys of the Teays River and its tributaries. The Minford member of the Teays Fm. was formed at this time as lacustrine silts and clays accumulated in the lake bed. These deposits are in two distinct stratigraphic units. The deepest unit is composed of relatively clean silts, indicative of shallow lake levels or overbank deposits; the upper unit is composed of a series of laminated clays that probably were deposited as Lake Tight increased in size and depth.

Eventually, Lake Tight overflowed its banks and initiated the "deep stage drainage"; the most significant deep stage stream in southern Ohio was the south-flowing Newark River. The Newark occupied the course of the present day Scioto River from Chillicothe to Portsmouth. As the glacier retreated, meltwater moved through the Newark River valley and partially backfilled it with outwash. The current drainage for the region, the Scioto River, is situated on a thick layer of outwash in the valley formed by the Newark River.

The geologic structure of the area is simple-the Mississippian strata dips gently to the east at approximately $30 \mathrm{ft} / \mathrm{mile}\left(0.3^{\circ}\right)$. A schematic cross section of the Portsmouth reservation and adjacent areas is presented in Fig. 7.2. No known major or minor faults are in the area; however, two distinct joint sets (i.e., fractures) are present in outcrops of the Sunbury and Berea. Azimuths for joint sets are $\mathrm{N} 65^{\circ} \mathrm{E}$ and $\mathrm{N} 25^{\circ} \mathrm{W}$. Bedding plane fractures also have been identified.

Surface soils at Portsmouth are composed of loess, colluvium, and more recently deposited alluvium. During the initial grading of the site prior to plant construction, elevated areas were removed and used to fill depressions. In most cases the fill is indistinguishable from undisturbed Minford deposits.

\section{Groundwater Hydrogeology}

The unconsolidated and bedrock systems at Portsmouth each include a low- and high-permeability unit. The Gallia sand and the Berea sandstone are the transmissive units at the Portsmouth site. The Gallia sand has the highest hydraulic conductivity and is the primary groundwater migration pathway. The hydraulic conductivity of the Minford silt member is somewhat lower than that of the Gallia sand but is much higher than that of the 
Minford clay member. The Gallia sand and the saturated portion of the Minford silt member act as a single hydrogeologic unit. The Berea sandstone is a regional geologic unit, and its relatively high hydraulic conductivity makes it the second lithologic unit with transmissive properties. The Minford clay member and the Sunbury shale exhibit lower hydraulic conductivities. The Minford clay member forms a semiconfining layer for the Gallia sand. The Sunbury shale, where more than $4 \mathrm{ft}$ thick, forms a confining layer for the Minford silt member and the Berea sandstone.

Based on numerous laboratory tests, the average hydraulic conductivity for the Minford clay is $2.3 \times 10^{-4} \mathrm{ft} /$ day and for the Minford silt is $4.3 \times 10^{-3} \mathrm{ft} /$ day. The vertical hydraulic conductivities of Minford clay and Minford silt are approximately an order of magnitude lower than their horizontal hydraulic conductivities. The hydraulic conductivity determined by single-well tests of the Gallia sand ranged from 0.11 to $150 \mathrm{ft} /$ day with a mean value of $3.4 \mathrm{ft} /$ day. The hydraulic conductivity of the Sunbury shale, based on modeling, ranges from $1.6 \times 10^{-4} \mathrm{ft} /$ day to $9.6 \times 10^{-4} \mathrm{ft} /$ day. The vertical hydraulic conductivity of the Sunbury shale is an order of magnitude lower than its horizontal hydraulic conductivity. The hydraulic conductivity determined by single-well tests of the Berea sandstone ranges from $4.5 \times 10^{-3}$ to $15 \mathrm{ft} /$ day with a mean value of $0.16 \mathrm{ft} /$ day. The higher hydraulic conductive results are from areas where the Sunbury shale is absent.

The Bedford shale is the lowest confining layer in the groundwater flow system because of its massive thickness and shale composition.

The Minford silt member, the Gallia sand, and the Berea sandstone make up the uppermost aquifer. The Gallia sand is the primary aquifer, or water-bearing zone, because it has the highest hydraulic conductivity, but it is not present everywhere. The Minford silt member and the Berea sandstone have somewhat lower hydraulic conductivities than the Gallia sand. Because it is regionally present, the Gallia sand is a regional water-bearing unit.

Based on water-level measurements from August 1993, the average elevation of the Gallia sand potentiometric surface at the Portsmouth facility ranges from more than $660 \mathrm{ft}$ above NGVD at the center of the facility to $620 \mathrm{ft}$ below NGVD on the south, east, and west and to $600 \mathrm{ft}$ below NGVD on the north. This results in a site-wide average water table depth of approximately 10 to $15 \mathrm{ft}$. Many factors can affect water table depth at a particular location, including seasonal variations resulting from increased or decreased precipitation, topography, land use, thickness of the upper clay portion of the Minford member, presence of storm drains, and operation of groundwater remediation processes. Future construction activities or additional groundwater treatment facilities will affect water table depth.

As previously discussed, Portsmouth is located in a valley. The industrialized portion of Portsmouth is located in the central portion of the valley. Four creeks or drainage channels drain the facility: Little Beaver Creek drains the eastern and northern portion; Big Run Creek and the unnamed drainage channel drain the southern, southwestern, and western portion; and the west drainage ditch drains the western portion. All ultimately discharge to the Scioto River. All four creeks and drainage ditches dissect the unconsolidated Minford silt and clay and Gallia sand, the bedrock-forming Sunbury shale (where present), and the Berea sandstone before exiting Portsmouth. Because the elevation of the water table is above the elevations of the creeks and drainage ditches, groundwater discharges to them.

Groundwater flow divides exist beneath Portsmouth where the groundwater flows toward one or another of these discharge locations. The groundwater divides in the Gallia sand and the Berea sandstone are located in approximately the same place. The locations vary throughout the year because of climatic conditions. Generally, the Berea sandstone and Gallia sand groundwater divides coincide. Migration of the groundwater divides in the Berea sandstone shows less seasonal variation than that of the Gallia sand.

The north-south trending groundwater divide for the Gallia sand runs from the south Portsmouth boundary between Big Run Creek and the unnamed drainage ditch toward the southern part of the X-326 building, where it follows the east side of the X-330 building. This drainage divide ends near the northern side of the X-330 building. Groundwater flow north of this drainage divide is to the north toward Little Beaver Creek. The northsouth trending drainage divide for the Berea sandstone is slightly displaced to the west of the Gallia groundwater drainage divide.

The east-west trending groundwater divide for the Gallia sand runs from the northwest corner of the X-7725 building toward the central portion of the X-326 building and then to the northern part of the X-100 building. The east-west trending groundwater divide for the Berea sandstone runs from the northwest corner of the X-7725 building toward the north side of the X-326 building and then runs due east. 
There are over 500 monitoring wells and piezometers (an instrument used to measure fluid pressure) at Portsmouth. Approximately 100 monitoring wells and 13 surface water monitoring locations are sampled routinely.

\section{USES OF GROUNDWATER IN THE VICINITY}

Groundwater is used as a domestic, municipal, and industrial water supply in the vicinity of Portsmouth. Most municipal and industrial water supplies in Pike County are developed from the Scioto Valley buried aquifer, which is where the largest towns and virtually all industry are located. Domestic water supplies are obtained from either unconsolidated deposits in preglacial valleys, major tributaries to the Scioto River, or from fractured bedrock encountered during drilling.

The Portsmouth facility is the largest industrial user of water in the vicinity and obtains its water from the X-608 water supply well field, which is next to the Scioto River just southwest of Piketon. The wells tap the Scioto River buried aquifer. Total groundwater production averages 13 million gal/day.

\section{APPLICABLE MONITORING STANDARDS}

A myriad of state and federal laws and regulations, as well as U.S. Department of Energy (DOE) orders, establish standards and requirements governing groundwater monitoring activities at Portsmouth. State and federal regulations, DOE orders, and guidance documents relevant to groundwater monitoring at Portsmouth are described in the following.

\section{State and Federal Laws and Regulations}

RCRA, with its accompanying regulations, is the primary federal law establishing groundwater monitoring requirements, although the Comprehensive Environmental Response, Compensation, and Liability Act (CERCLA) also contains certain requirements. The U.S. Environmental Protection Agency (USEPA) promulgates and enforces federal groundwater monitoring regulations. Portsmouth is located in USEPA Region V, which is headquartered in Chicago and encompasses the midwestern states.

The Ohio Environmental Protection Agency (OEPA) promulgates and enforces state groundwater monitoring regulations, which must be consistent with federal regulations. Portsmouth is located within the jurisdiction of the OEPA Southeast District Office in Logan, Ohio. The OEPA is authorized to manage the RCRA and Hazardous and Solid Waste Amendment (HSWA) program in Ohio, excluding the authority to issue interim status corrective orders. The OEPA has primary enforcement authority for RCRA requirements within its authorization.

State and federal regulations governing groundwater monitoring at Portsmouth are briefly described in the following.

\section{Title 40, Code of Federal Regulations, Part 265, Subpart F; Part 264, Subpart F; and Corresponding State Regulations}

RCRA groundwater monitoring requirements have been established in phases. Initial requirements, or interim status requirements, are prescribed by Title 40, Code of Federal Regulations, Part 265 (40 CFR 265) or Ohio Administrative Code (OAC) 3745-65-90 through -94. Interim status groundwater monitoring requirements are applied to all authorized interim status hazardous waste management units. Basically, the $40 \mathrm{CFR} 265$ standards require that a facility (1) monitor for detection of contaminants in groundwater; (2) prepare a groundwater quality assessment plan to be implemented in the event contaminants are discovered; and (3) monitor to assess the extent of contamination, as required by the groundwater quality assessment plan. Groundwater monitoring requirements are to continue through the post-closure period of the facility.

In 40 CFR 264, Subpart $F$, and OAC 3745-54-90 through -99 are prescribed the more stringent standards facilities must meet upon receipt of their final administrative permit, issued pursuant to a RCRA permit application. Until 1984, Part 264, Subpart F, standards applied only to regulated units, as specifically defined in RCRA. Under Part 264, facilities were required to set up a groundwater monitoring program for each regulated unit consisting of at least one of three stages (detection monitoring, compliance monitoring, or corrective action). 
Detection monitoring is conducted to detect contamination. Once detected, a groundwater protection standard (GWPS), in the form of a maximum contaminant level or alternate concentration limit, is formulated for each hazardous constituent of concern. Compliance monitoring is conducted to verify that the GWPS is not exceeded. If the GWPS is exceeded, the facility must institute corrective action to clean up the contaminant(s) to the GWPS level. During the corrective action stage, the facility must conduct groundwater monitoring to demonstrate the effectiveness of the corrective action program. Monitoring in the corrective action stage must be at least as effective as groundwater monitoring in the compliance stage and is to continue through the post-closure period of the facility.

\section{RCRA Sections 3004(u) and 3008(h), Corrective Action, and Proposed Subpart S}

In 1984, RCRA was amended by the HSWAs, which contain two important provisions. First, the amendments extend the number of units subject to corrective action requirements by creating a solid waste management unit (SWMU) and subjecting all SWMUs to corrective action at the time the facility submits its RCRA permit application [RCRA, Section 3004(u)]. RCRA, Section 3004(u), is implemented through 40 CFR 264.101, Subpart F, and the corresponding state rule, OAC 3745-55-011. Thus, groundwater monitoring under corrective action is conducted according to 40 CFR 264, Subpart F, rather than the less stringent 40 CFR 265 interim status regulations.

In July 1990, the USEPA proposed a major rulemaking to implement RCRA, Section 3004(u), "Corrective Action for Solid Waste Management Units (SWMUs) at Hazardous Waste Management Facilities." In establishing a complete regulatory scheme for corrective action, a new Subpart $S$ in Part 264 was created as a result of the proposal. Among other changes, the proposal would delete 40 CFR 264.101 and repromulgate it as the new 40 CFR 264.500 in Subpart S. This change is still in proposed form, as is most of the July 1990 rulemaking.

Second, the HSWAs create a vehicle to apply Part 264, Subpart F, groundwater monitoring requirements to RCRA-regulated units before the regulated units receive their final administrative permits by use of a Section 3008(h) interim status corrective action order. As another provision of these amendments, RCRA, Section 3004(v), requires corrective action for hazardous waste or hazardous constituent releases beyond the facility boundary.

\section{Closure and Post-Closure Care Requirements}

Closure and post-closure care include requirements for groundwater monitoring. Federal closure and postclosure interim status requirements are found in 40 CFR 265, Subpart G. Corresponding state regulations are in OAC 3745-66. Final standards, which apply upon issuance of the final administrative permit, are found in 40 CFR 264, Subpart G. Corresponding state regulations are in OAC 3745-55.

\section{Part B Permit Application Requirements}

Title 40 CFR 270, Subpart B, and OAC 3745-50-44(B) specify that groundwater monitoring information and plan requirements are to be submitted as part of the facility's RCRA permit application.

\section{Final Administrative Permit Conditions}

Title 40 CFR 270, Subpart C, and OAC 3745-50-58(J) specify that record keeping and reporting requirements for groundwater monitoring data are to be collected under the appropriate permit.

\section{Underground Storage Tank (UST) Requirements}

Groundwater monitoring is required in certain instances for USTs. Technical standards and corrective action requirements for owners and operators of USTs can be found in 40 CFR 280, Subparts D, E, F, and G. Corresponding state regulations can be found in OAC 1301:7-9-07, 7-9-12, 7-9-13, and 7-9-14. 


\section{CERCLA Requirements}

Title 40 CFR 300, Subpart F, requires evaluation of groundwater contamination and hydrogeological conditions when considering remedial alternatives for CERCLA sites.

\section{Solid Waste Requirements}

Ohio Administrative Code 3745-27 requires groundwater monitoring for releases at solid waste disposal sites. The code includes detailed sampling and analysis plan requirements and requirements for monitoring well construction and installation. State solid waste groundwater monitoring requirements parallel those for hazardous waste.

\section{DOE Orders}

DOE orders contain basic legal requirements for DOE programs and operations. Several DOE orders contain references to groundwater protection or monitoring. Contaminated groundwater shall be managed or decontaminated under the procedures and requirements of DOE Order 5480.4 and the 5400 series. A list of the orders and a summary of these requirements follow.

\section{1, General Environmental Protection Program}

DOE Order 5400.1 states that "it is DOE policy to conduct the Department's operations in compliance with the letter and spirit of applicable environmental statutes, regulations, and standards." The order recognizes that where USEPA, state, and local environmental agencies "clearly exercise environmental protection authority through permitting and compliance administrative procedures applicable to DOE, they establish and regulate required performance for environmental protection."

DOE Order 5400.1 defines environmental monitoring as consisting of effluent monitoring and environmental surveillance and establishes detailed requirements for both a groundwater protection management program and a groundwater monitoring program. The Groundwater Protection Program (GWPP) Management Plan must be reviewed annually and updated every three years. The plan should include

- documentation of the groundwater regime with respect to quantity and quality;

- design and implementation of a groundwater monitoring program to support resource management and comply with applicable environmental laws and regulations;

- a management program for groundwater protection and remediation, including specific Safe Drinking Water Act, RCRA, and CERCLA action; .

- a summary and identification of areas that may be contaminated with hazardous substances;

- strategies for controlling sources of these contaminants;

- a remedial action program that is part of the site CERCLA program required by DOE Order 5400.4; and

- decontamination and decommissioning and other remedial programs contained in DOE directives.

A groundwater monitoring program is to be developed as part of any environmental monitoring plan and for the groundwater protection management program. The groundwater monitoring program shall conform with RCRA standards, where appropriate. Monitoring for radionuclides is to be conducted in accordance with DOE orders.

In addition to these general requirements, DOE Order 5400.1 also contains recommendations regarding monitoring well construction and location, groundwater sampling frequency, sampling and analytical methods, sample sizes, and methods of sample preservation. 


\subsection{A, Environmental Compliance Issue Coordination}

This order requires coordination of environmental issues that are of significance to DOE, including groundwater protection.

\subsection{3, Hazardous and Radioactive Mixed Waste Management}

Under this order, DOE must manage hazardous and radioactive mixed waste according to the requirements of RCRA, including those of 40 CFR 264 and 265. 'RCRA applies to the extent it is not inconsistent with the Atomic Energy Act (AEA). The radioactive component of radioactive mixed waste is subject to the requirements of DOE 5820.2A."

\section{4, Comprehensive Environmental Response, Compensation, and Liability Act Program}

This order requires that corrective actions under RCRA or state laws be performed in a manner that satisfies CERCLA requirements, where appropriate.

\section{5, Radiation Protection of the Public and the Environment}

The purpose of this order is to protect the public and the environment from risk of radioactive contamination. The order establishes (1) a standard of high quality for DOE monitoring and surveillance programs, (2) authorized contamination limits for release of property, and (3) as-low-as-reasonably-achievable considerations. The order mandates that drinking water criteria be consistent with 40 CFR 141, "National Interim Primary Drinking Water Regulations." Derived concentration guidelines, or the concentration of radionuclides in water that under conditions of continuous exposure for one year by one exposure mode would result in an effective dose equivalent of $100 \mathrm{mrem}$, are established. Finally, the order states that long-term management of groundwater shall be in accordance with legally applicable federal and state standards.

\section{4, Environmental Profection, Safety, and Health Protection Standards}

This order specifies statutory and regulatory provisions that apply to DOE programs and operations.

\subsection{A, Management of Low-Level Waste}

This order establishes that environmental monitoring associated with low-level and mixed radioactive waste management activities shall be conducted in accordance with DOE Order 5400.1 and may include groundwater monitoring. The monitoring program must be able to measure

- operational effluent releases,

- migration of radionuclides,

- disposal unit subsidence, and

- changes in disposal facility and disposal site parameters that may affect long-term site performance.

Moreover, the monitoring program must be capable of detecting changing trends in time to apply appropriate corrective action measures.

This order also establishes policies and guidelines for decontamination and decommissioning of DOE facilities. Programs must follow all applicable federal, state, and local requirements.

Finally, this order requires that a waste management plan outline be prepared that discusses, among other items, the environmental monitoring programs at individual waste management facilities. 


\section{Consent Decree and Consent Order}

The Ohio Consent Decree entered into on August 29, 1989, and the RCRA, Section 3008(h), Administrative Consent Order entered into with USEPA Region V on September 29, 1989, outline requirements and schedules for the RFI at Portsmouth. These documents include specific dates and deliverables that must be followed throughout the RFI, the corrective measures study, and corrective measures implementation. In addition, these documents include (1) specific interim remedial measures: a site-wide environmental audit, trichloroethylene (TCE) removal from groundwater at X-701B, and runoff sampling at X-749; (2) changes in environmental management practices, development of a polychlorinated biphenyl (PCB) spill cleanup plan, and modifications of the site contingency plan and waste tracking system; (3) completion of groundwater quality assessments (GWQAs) at X-701B, X-749, X-231B, and X-616; and (4) development of an interim remedial measures plan for off-site contamination.

Under the USEPA Administrative Consent Order, Portsmouth is to conduct a groundwater investigation to characterize any plumes of contamination at the facility. The language of the order parallels language of 40 CFR 264, Subpart F, and OAC 3745-54-90 through -99, requiring that groundwater protection standards be established for any groundwater contaminants found. The order also lists the four RCRA interim status units as hazardous waste disposal and storage areas. In addition, it identifies the X-231B, X-616, and X-749 facilities as SWMUs.

The Ohio Consent Decree acknowledges receipt of the GWQA, as required under 40 CFR 265, Subpart F, and $\mathrm{OAC}$ 3745-55-90 through -65-94, and requires that a hydrogeologic investigation be conducted as part of the site investigation to determine the present and potential extent of groundwater contamination. Long-term disposition of contaminants will be evaluated when the investigation is complete. The decree labels the four RCRA interim status units as hazardous waste treatment, storage, and disposal areas but includes only X-701B in its list of waste units.

Both of these documents will serve as major sources of information and guidance throughout the RFI, corrective measures study, and corrective measures implementation. At this time, directives stipulated by both documents are consistent with groundwater investigations conducted at Portsmouth in response to the federal and state regulations and DOE orders. As such, the monitoring strategies presented in the following section will be limited to the specific regulations and/or DOE orders.

\section{Guidance Documents}

The RCRA Groundwater Monitoring Technical Enforcement Guidance Document (USEPA 1989a) is the applicable guidance document actively used by the Portsmouth GWPP.

\section{GROUNDWATER MONITORING AT PORTSMOUTH}

Portsmouth has six RCRA interim status units (see Fig. 7.3) at which groundwater monitoring is specified in 40 CFR 265.93, Subpart F, and OAC 3745-65. Under these regulations, detection monitoring is performed at units where there has been no statistically significant exceedence of threshold levels of groundwater indicator parameters at downgradient wells. These parameters are listed in Table 7.2. In the event of statistically significant exceedence of these parameters at downgradient wells, the groundwater contaminant plume associated with the unit is characterized during a GWQA and assessment monitoring is performed on a quarterly basis.

Detection monitoring is being performed at two units: (1) the X-735 landfill and (2) the X-701C neutralization pit. Assessment monitoring is performed at four units: (1) the X-701B holding pond, (2) X-749 south contaminated materials storage yard, (3) X-231B southwest oil biodegradation plot, and (4) the X-616 liquid effluent control facility.

The surveillance monitoring program at Portsmouth consists of perimeter exit pathway monitoring, off-site sampling, and baseline monitoring. The purpose of perimeter exit pathway monitoring is to assess the effect of Portsmouth on regional groundwater quality and quantity. The off-site sampling addresses public concern about the effect of Portsmouth operations on nearby residential and public water supplies. Baseline monitoring is conducted to establish baseline data, which is used to support various efforts including permit applications. 


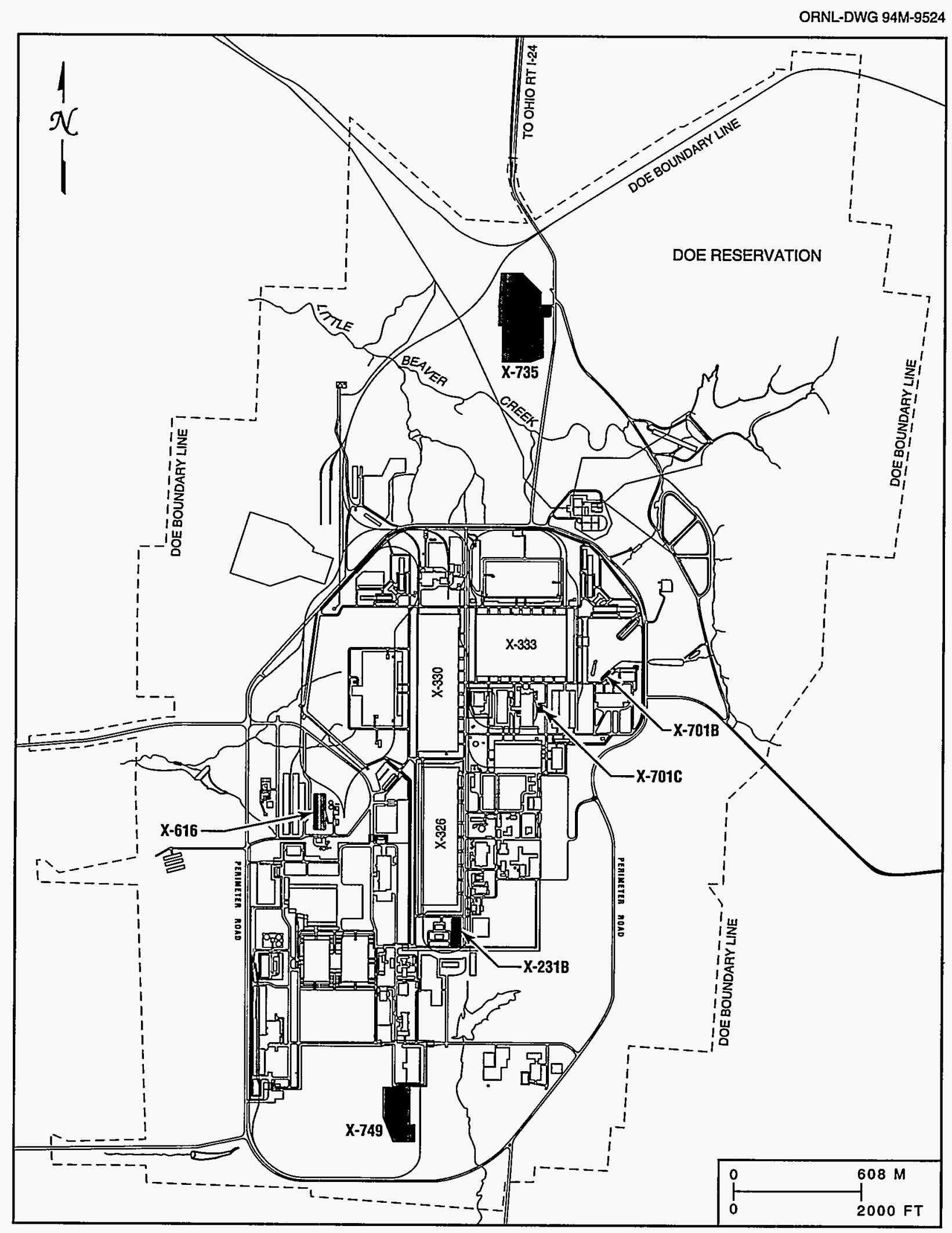

Fig. 7.3. Portsmouth RCRA interim status land disposal unit locations. 
Table 7.2. Analyte analysis required for groundwater monitoring at RCRA units, the sanitary landfill, surface water locations, off-site locations, and the X-701C neutralization pit

\begin{tabular}{|c|c|c|c|c|c|c|c|c|}
\hline \multirow[b]{2}{*}{ Analyte } & \multicolumn{8}{|c|}{ Monitoring location } \\
\hline & $\mathrm{X}-701 \mathrm{~B}^{a}$ & $\mathrm{X}-749^{a}$ & $\mathrm{X}-231 \mathrm{~B}^{a}$ & $\mathrm{X}-616^{\alpha}$ & $X-735^{b}$ & $\begin{array}{l}\text { Surface } \\
\text { water }\end{array}$ & Off-site & $701 C$ \\
\hline \multicolumn{9}{|c|}{$\begin{array}{l}\text { Volatile organic halogens } \\
\text { (Method 8010) }\end{array}$} \\
\hline Vinyl chloride & $\checkmark$ & $\checkmark$ & $\checkmark$ & $\checkmark$ & $\checkmark$ & $\checkmark$ & $\sqrt{ }$ & $\checkmark$ \\
\hline Trichlorofluoromethane & $\checkmark$ & $s$ & 8 & $s$ & $\checkmark$ & $\checkmark$ & 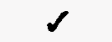 & $\Omega$ \\
\hline Freon-113 & $\checkmark$ & $\checkmark$ & $\checkmark$ & $\checkmark$ & $\checkmark$ & $\checkmark$ & $d$ & $\checkmark$ \\
\hline 1,1-dichloroethene & $\checkmark$ & $\checkmark$ & 8 & $\checkmark$ & $\checkmark$ & $\checkmark$ & $\checkmark$ & $\checkmark$ \\
\hline Methylene chloride & $\checkmark$ & $\checkmark$ & $\checkmark$ & 8 & $\checkmark$ & $\checkmark$ & $\checkmark$ & $\checkmark$ \\
\hline Trans-1,2-dichloroethene & $\checkmark$ & $\checkmark$ & $\checkmark$ & 8 & $\checkmark$ & $\checkmark$ & $\checkmark$ & $\checkmark$ \\
\hline 1,1-dichloroethane & $\checkmark$ & $\checkmark$ & $\checkmark$ & $\checkmark$ & $\checkmark$ & 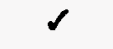 & $\checkmark$ & $\checkmark$ \\
\hline Cis-1,2-dichloroethene & $\checkmark$ & 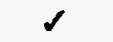 & 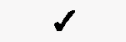 & $s$ & $\checkmark$ & 8 & $\checkmark$ & $\checkmark$ \\
\hline Chloroform & $\checkmark$ & $\checkmark$ & $\checkmark$ & $\checkmark$ & $\checkmark$ & $\checkmark$ & $\checkmark$ & $\checkmark$ \\
\hline 1,1,1-trichloroethane & $\checkmark$ & $\checkmark$ & $\checkmark$ & $\checkmark$ & $s$ & $\checkmark$ & $\checkmark$ & $s$ \\
\hline Carbon tetrachloride & $\checkmark$ & $\checkmark$ & $s$ & $\checkmark$ & $\checkmark$ & $\checkmark$ & $\checkmark$ & $\checkmark$ \\
\hline 1,2-dichloroethane & $\checkmark$ & $\checkmark$ & $\checkmark$ & $\checkmark$ & $\checkmark$ & $\checkmark$ & $\checkmark$ & $\checkmark$ \\
\hline Trichloroethene & $\checkmark$ & $\checkmark$ & $\checkmark$ & $\checkmark$ & $\checkmark$ & $\checkmark$ & $\checkmark$ & $s$ \\
\hline Bromodichloromethane & $\checkmark$ & $\checkmark$ & $\checkmark$ & $\checkmark$ & $\checkmark$ & $\checkmark$ & $\checkmark$ & $\checkmark$ \\
\hline 1,1,2-trichloroethane & $\checkmark$ & $\checkmark$ & $\checkmark$ & $\checkmark$ & $\checkmark$ & $\checkmark$ & $\checkmark$ & $\checkmark$ \\
\hline Tetrachloroethene & & $\checkmark$ & $\checkmark$ & $\checkmark$ & $\checkmark$ & $\checkmark$ & $\checkmark$ & $\checkmark$ \\
\hline Dibromochloromethane & 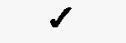 & $\checkmark$ & $\checkmark$ & $\checkmark$ & $\checkmark$ & $\checkmark$ & $\checkmark$ & $\checkmark$ \\
\hline Bromoform & $\checkmark$ & $\checkmark$ & $\checkmark$ & $\checkmark$ & $\checkmark$ & $\checkmark$ & $\checkmark$ & $\checkmark$ \\
\hline \multicolumn{9}{|c|}{$\begin{array}{l}\text { Volatile organic compounds } \\
\text { (Method 8240) }\end{array}$} \\
\hline Acetone & $\checkmark$ & $\checkmark$ & $\checkmark$ & 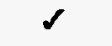 & $\checkmark$ & $\checkmark$ & $\checkmark$ & $\checkmark$ \\
\hline Benzene & $\checkmark$ & $\checkmark$ & $\checkmark$ & $\checkmark$ & $\checkmark$ & $\checkmark$ & $\checkmark$ & $\checkmark$ \\
\hline Bromodichloromethane & $\checkmark$ & $\checkmark$ & $\checkmark$ & $\checkmark$ & $\checkmark$ & $\checkmark$ & $\checkmark$ & $\checkmark$ \\
\hline Bromoform & $\checkmark$ & $\checkmark$ & $\checkmark$ & $\checkmark$ & $\checkmark$ & $\checkmark$ & $\checkmark$ & $\checkmark$ \\
\hline Bromomethane & $\checkmark$ & $\checkmark$ & $\checkmark$ & $\checkmark$ & $\checkmark$ & $\checkmark$ & $\checkmark$ & $\checkmark$ \\
\hline 2-butanene & $\checkmark$ & $\checkmark$ & $\checkmark$ & $\checkmark$ & $\checkmark$ & $\checkmark$ & $\checkmark$ & $\checkmark$ \\
\hline Carbon disulfide & $\checkmark$ & $\checkmark$ & $\checkmark$ & 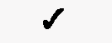 & $\checkmark$ & $\checkmark$ & $\checkmark$ & $\checkmark$ \\
\hline Carbon tetrachloride & $\checkmark$ & $s$ & $\checkmark$ & $\checkmark$ & $\checkmark$ & $\checkmark$ & $\checkmark$ & $\checkmark$ \\
\hline Chlorobenzene & $\checkmark$ & $\checkmark$ & $\checkmark$ & $\checkmark$ & 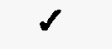 & $\checkmark$ & $\checkmark$ & $\checkmark$ \\
\hline Chlorodibromomethane & $\checkmark$ & $\checkmark$ & $\checkmark$ & $\varsigma$ & $\checkmark$ & $\checkmark$ & $\checkmark$ & $\checkmark$ \\
\hline Chloroethane & $\checkmark$ & $\checkmark$ & $\checkmark$ & $\checkmark$ & $\checkmark$ & $\checkmark$ & $\checkmark$ & $\checkmark$ \\
\hline Chloroform & $\checkmark$ & $\checkmark$ & $\checkmark$ & $\checkmark$ & $\checkmark$ & $\checkmark$ & $\checkmark$ & $\checkmark$ \\
\hline Dichlorobenzenes & $\checkmark$ & $\checkmark$ & $\checkmark$ & $\checkmark$ & $\checkmark$ & $\checkmark$ & $\checkmark$ & $\checkmark$ \\
\hline 1,1-dichloroethane & $\checkmark$ & $c$ & $\checkmark$ & $\checkmark$ & $\checkmark$ & $\checkmark$ & $\checkmark$ & $\checkmark$ \\
\hline 1,2-dichloroethane & $\checkmark$ & $c$ & $\checkmark$ & $\checkmark$ & $\checkmark$ & $\checkmark$ & $\checkmark$ & $\checkmark$ \\
\hline 1,1-dichloroethene & $\checkmark$ & $c$ & $\checkmark$ & $\checkmark$ & $\checkmark$ & $\checkmark$ & $\checkmark$ & $\checkmark$ \\
\hline 1,2-dichloroethene (cis/trans) & $\checkmark$ & $c$ & $\checkmark$ & $\checkmark$ & $\checkmark$ & $\checkmark$ & $\checkmark$ & $\checkmark$ \\
\hline Ethyl benzene & $\checkmark$ & $\checkmark$ & $\checkmark$ & $\checkmark$ & $\checkmark$ & $\checkmark$ & $\checkmark$ & $\checkmark$ \\
\hline Freon-113 & $\checkmark$ & $c$ & $\checkmark$ & $\checkmark$ & $\checkmark$ & $\checkmark$ & $\checkmark$ & $\checkmark$ \\
\hline Freon-114 & $\checkmark$ & $\checkmark$ & $\checkmark$ & $\checkmark$ & $\checkmark$ & $\checkmark$ & $\checkmark$ & $\checkmark$ \\
\hline 4-methyl-2-pentanene & $\checkmark$ & $\checkmark$ & $\checkmark$ & $\checkmark$ & $\checkmark$ & $\checkmark$ & $\checkmark$ & $\checkmark$ \\
\hline 1,1,2,2-tetrachloroethane & $\checkmark$ & $\checkmark$ & $\checkmark$ & $\checkmark$ & $\checkmark$ & $\checkmark$ & $\checkmark$ & $\checkmark$ \\
\hline Tetrachloroethene & $\checkmark$ & $\checkmark$ & $\checkmark$ & $\checkmark$ & $\checkmark$ & $\checkmark$ & $\checkmark$ & $\checkmark$ \\
\hline Toluene & $\checkmark$ & $\checkmark$ & $\checkmark$ & $\checkmark$ & $\checkmark$ & $\checkmark$ & $\checkmark$ & $\checkmark$ \\
\hline 1,1,1-trichloroethane & $\checkmark$ & $c$ & $\checkmark$ & $\checkmark$ & $\checkmark$ & $\checkmark$ & $\checkmark$ & $\checkmark$ \\
\hline
\end{tabular}


Table 7.2 (continued)

\begin{tabular}{|c|c|c|c|c|c|c|c|c|}
\hline \multirow[b]{2}{*}{ Analyte } & \multicolumn{8}{|c|}{ Monitoring location } \\
\hline & $\mathrm{X}-701 \mathrm{~B}^{a}$ & $X-749^{a}$ & $X-231 B^{a}$ & $X-616^{a}$ & $X-735^{b}$ & $\begin{array}{c}\text { Surface } \\
\text { water }\end{array}$ & Off-site & $701 C$ \\
\hline 1,1,2-trichloroethane & $\checkmark$ & $\checkmark$ & $\checkmark$ & $\checkmark$ & $\checkmark$ & $\checkmark$ & $\checkmark$ & $\checkmark$ \\
\hline Trichloroethylene & $c$ & $c$ & $c$ & $c$ & $c$ & $c$ & $\checkmark$ & $c$ \\
\hline Trichlorofluoromethane & $\checkmark$ & $\checkmark$ & $\checkmark$ & $\checkmark$ & $\checkmark$ & $\checkmark$ & $\checkmark$ & $\checkmark$ \\
\hline Vinyl chloride & $\checkmark$ & $\checkmark$ & $\checkmark$ & $\checkmark$ & $\checkmark$ & $\checkmark$ & $\checkmark$ & $\checkmark$ \\
\hline Xylenes & $\checkmark$ & $\checkmark$ & $\checkmark$ & $\checkmark$ & $\checkmark$ & $\checkmark$ & $\checkmark$ & $\checkmark$ \\
\hline \multicolumn{9}{|c|}{ Radionuclide parameters } \\
\hline Gross alpha & $\checkmark$ & $\checkmark$ & $\checkmark$ & $\checkmark$ & $\checkmark$ & $\checkmark$ & $\checkmark$ & $\checkmark$ \\
\hline Gross beta & $\checkmark$ & $\checkmark$ & $\checkmark$ & $\checkmark$ & $\checkmark$ & $\checkmark$ & $\checkmark$ & $\checkmark$ \\
\hline Total uranium & $\checkmark$ & $\checkmark$ & $\checkmark$ & $\checkmark$ & $\checkmark$ & $\checkmark$ & $\checkmark$ & $\checkmark$ \\
\hline Technetium beta & $\checkmark$ & $\checkmark$ & $\checkmark$ & $\checkmark$ & $\checkmark$ & $\checkmark$ & $\checkmark$ & $\checkmark$ \\
\hline Transuranics & $\checkmark$ & $\checkmark$ & $\checkmark$ & & $\checkmark$ & $\checkmark$ & & \\
\hline Isotopic uranium & $\checkmark$ & $\checkmark$ & $\checkmark$ & & $\checkmark$ & $\checkmark$ & & \\
\hline \multicolumn{9}{|c|}{ Metals } \\
\hline Arsenic & & & & & $\checkmark$ & & & \\
\hline Barium & & & $\checkmark$ & $\checkmark$ & $\checkmark$ & & & \\
\hline Cadmium & $\checkmark$ & $\checkmark$ & & $\checkmark$ & $\checkmark$ & & & $\checkmark$ \\
\hline Copper & & & & & $\checkmark$ & & & \\
\hline Chromium & $\checkmark$ & $\checkmark$ & $\checkmark$ & $\checkmark$ & $\checkmark$ & & & $\checkmark$ \\
\hline Iron & $\checkmark$ & $\checkmark$ & $\checkmark$ & $\checkmark$ & $\checkmark$ & $\checkmark$ & & $\checkmark$ \\
\hline Lead & $\checkmark$ & $\checkmark$ & $\checkmark$ & $\checkmark$ & $\checkmark$ & 2 & & \\
\hline Magnesium & $\checkmark$ & $\checkmark$ & $\checkmark$ & $\checkmark$ & $\checkmark$ & $\checkmark$ & & $\checkmark$ \\
\hline Manganese & & & & $\checkmark$ & $\checkmark$ & & & \\
\hline Mercury & & & & & $\checkmark$ & & & \\
\hline Nickel & $\checkmark$ & & $\checkmark$ & $\checkmark$ & $\checkmark$ & & & $\checkmark$ \\
\hline Potassium & $\checkmark$ & $\checkmark$ & $\checkmark$ & $\checkmark$ & $\checkmark$ & $\checkmark$ & & $\checkmark$ \\
\hline Selenium & & & & & $\checkmark$ & & & \\
\hline Silver & & & & & $\checkmark$ & & & \\
\hline Sodium & $\checkmark$ & $\checkmark$ & $\checkmark$ & $\checkmark$ & $\checkmark$ & $\checkmark$ & & $\checkmark$ \\
\hline Zinc & & & & & $\checkmark$ & & & \\
\hline
\end{tabular}

Ammonia

Nitrate

Nitrite

Chloride

Calcium

Sulfates

Phosophorus

Phenols

Other chemical parameters

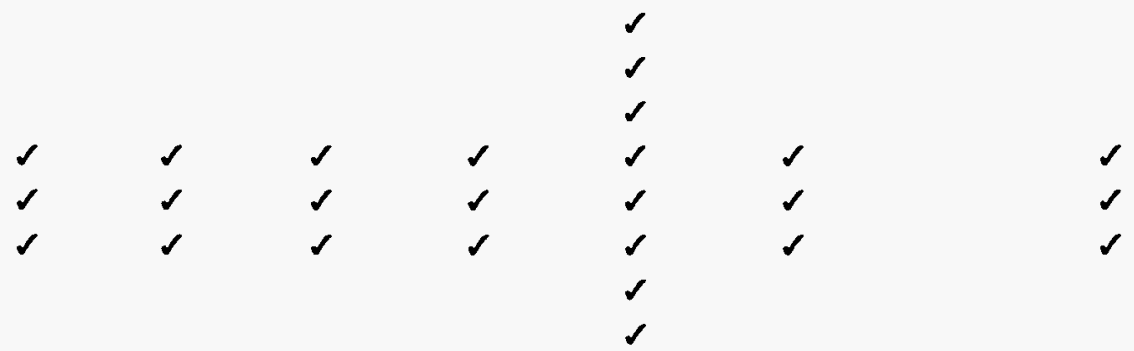

Total dissolved solids

Other physical parameters

Total organic carbon

Chemical oxygen demand

Total alkalinity

Turbidity

RCRA unit.

'Sanitary landfill.

'Primary volatile organic compounds of concern. 
Three special groundwater investigations began in 1993. One of these included sampling and analyzing seeps emanating from the Peter Kiewit Landfill. The second investigation was a geologic and hydrogeologic investigation for a new sanitary landfill site. The third investigation was an assessment of two UST sites.

In 1993, the RFI for Quadrant IV was conducted. Quadrant IV is located in the northern portion of Portsmouth.

\section{Detection Monitoring}

Detection monitoring is being performed at two units: (1) the X-735 landfill and (2) the X-701C neutralization pit.

\section{X-735 Landfill}

The X-735 landfill is located on the northern part of Portsmouth (see Fig 7.4). Initially, a total of 17.9 acres was approved for landfill use by the OEPA and the Pike County Department of Health for the disposal of sanitary solid waste. An investigation conducted by Portsmouth indicated that wipe rags contaminated with solvents had inadvertently been disposed of in cells 1 through 6 of the landfill. The OEPA has determined that these cells must be closed as a RCRA hazardous waste landfill. The remaining three cells are regulated by solid waste regulations.

The cells containing hazardous waste occupy the northern part of the landfill, and the cells that contain only sanitary solid waste occupy the southern part. There is an undisturbed buffer between the two sections.

\section{Groundwater Investigations}

Seven wells are used for monitoring. Currently, these wells surround the perimeter of the entire landfill (both RCRA and sanitary solid waste sections). In 1994 additional point-of-compliance monitoring wells will be installed during the RCRA closure of cells 1 through 6.

\section{Groundwater Flow}

The calculated hydraulic conductivity $(K)$ ranges from a high of $1440 \mathrm{ft} /$ day to a low of $4.3 \mathrm{ft} /$ day. The arithmetic mean hydraulic conductivity value of $430 \mathrm{ft} /$ day is used in determining groundwater flow velocity for the Gallia sand. The calculated groundwater flow rates range from 3.4 to $5.2 \mathrm{ft} / \mathrm{day}$.

\section{Extent of Contamination}

Statistical analysis of the indicator parameters indicates that no contamination exists downgradient of the X-735 sanitary landfill. No volatile organic compounds (VOCs) have been detected consistently. The VOC carbon disulfide has occasionally been detected, but is believed to be the result of sampling- or laboratory-induced contamination.

\section{X-701C Neutralization Pit}

The X-701C neutralization pit consists of a neutralization pit and a pump pit (see Fig. 7.5). The neutralization pit has an area of $25 \mathrm{ft}^{2}$ and is $18 \mathrm{ft}$ deep. The floors and walls are constructed of concrete and lined with acid-proof brick. A sump in the bottom of the neutralization pit drains into the adjacent pump pit. The pump pit, which is constructed of concrete, has an area of about $81 \mathrm{ft}^{2}$ and is $9 \mathrm{ft}$ deep. Two feeder lines enter the X-701C pit, an 8-in. line from the X-700 chemical cleaning facility and a 4-in. line from the X-701A lime house.

\section{Groundwater Investigations}

The vicinity of the X-701C neutralization pit was included in the seven-unit investigative area of the Quadrant II RFI conducted in 1991. 


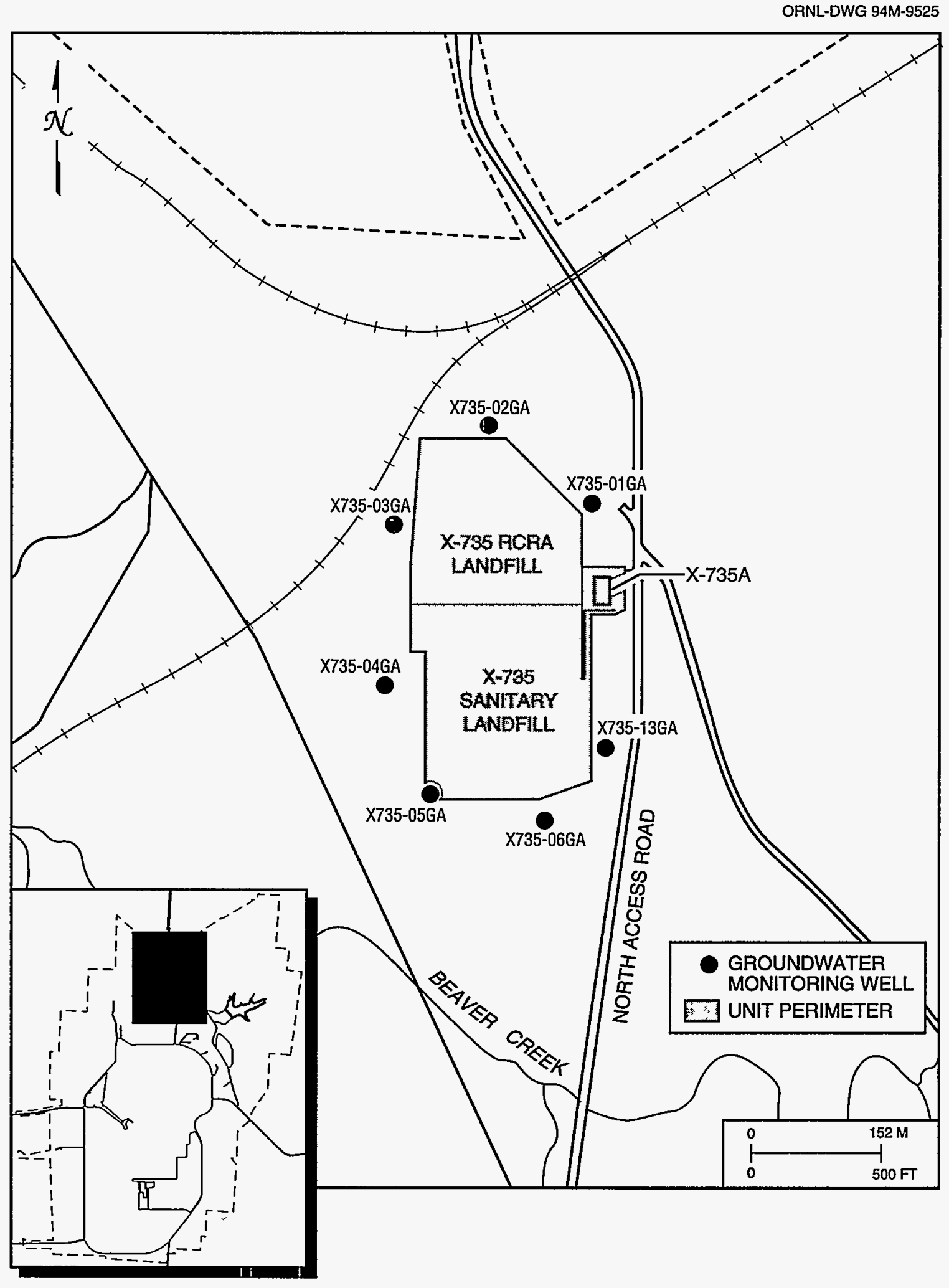

Fig. 7.4. X-735 landfill monitoring well locations. 


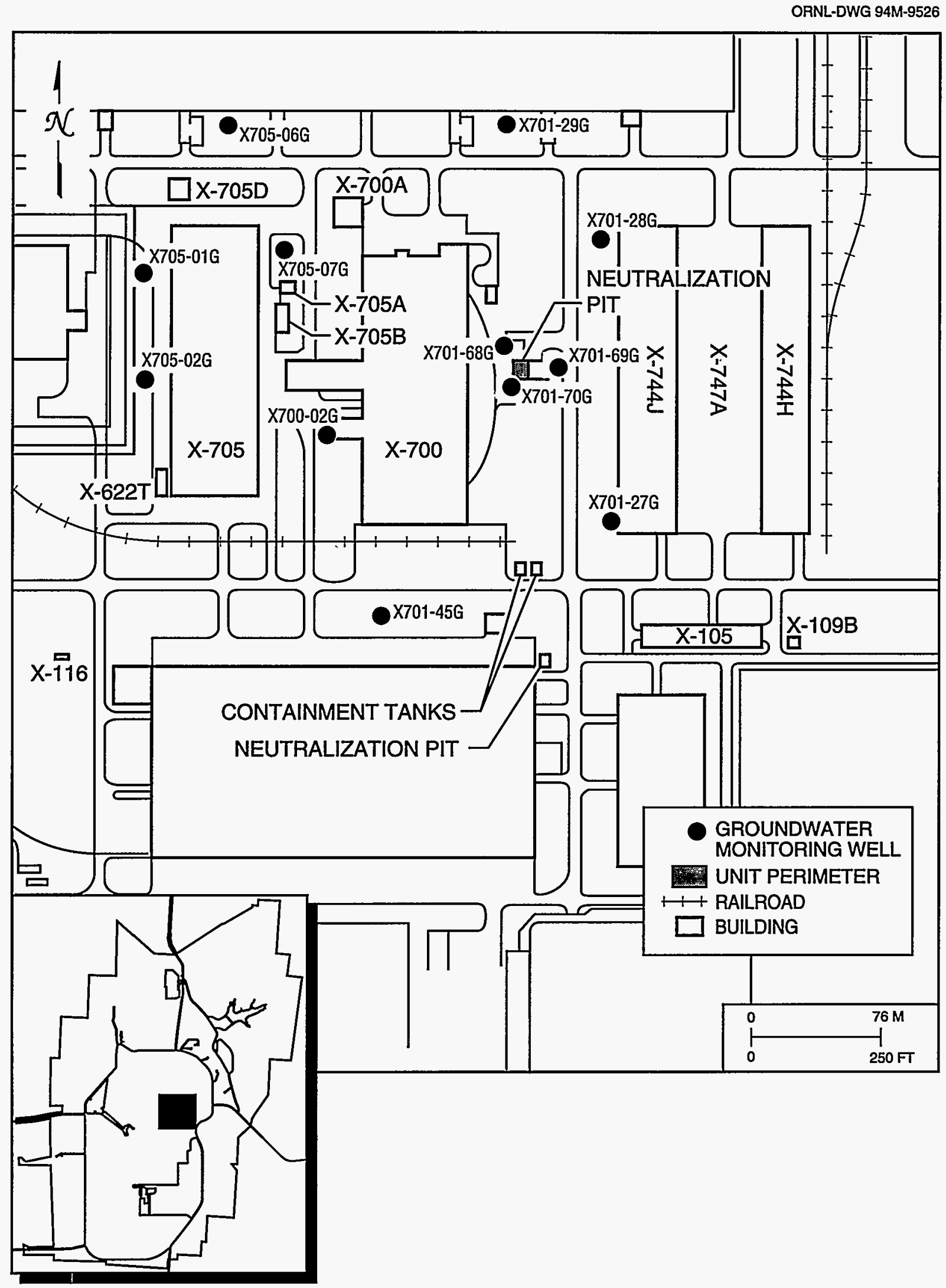

Fig. 7.5. X-701C neutralization pit monitoring well locations. 


\section{Groundwater Flow}

Groundwater flow in the vicinity of the X-701C neutralization pit is to the west toward the X-700 building (see Fig. 7.5). Groundwater flow in this direction is caused by the pumping of sumps in the X-700 and X-705 buildings, which has also caused a cone of depression centered under these buildings. This is a local reversal of direction of groundwater flow. Without the pumping of these sumps, groundwater flow would be to the east toward Little Beaver Creek. With the induced groundwater flow direction, the upgradient well is X701-69G and downgradient wells are X701-68G and X701-70G.

The hydraulic conductivity of the Gallia sand in the vicinity of the X-701C neutralization pit is about $100 \mathrm{ft} /$ day. Calculated groundwater flow velocities range from 2.0 to $2.4 \mathrm{ft} /$ day.

\section{Extent of Contamination}

Results of the Quadrant II RFI indicate that the X-701C neutralization pit is located within a TCE groundwater plume centered under the X-700 chemical cleaning facility and the X-705 decontamination building.

\section{Assessment Monitoring}

Assessment groundwater monitoring is being performed on four RCRA units. Assessment monitoring is performed at the X-701B holding pond, X-749 south contaminated materials storage yard, and X-231B southwest oil biodegradation plot (see Fig. 7.3) because groundwater contaminants have been detected in the groundwater. The contaminants are mainly VOCs $\left[1,1,1\right.$-trichloroethane (TCA) and TCE] and low-energy beta emitters $\left({ }^{99} \mathrm{Tc}\right)$. Assessment monitoring is performed at the X-616 liquid effluent control facility because although no solvent or radionuclide contamination has been consistently detected groundwater indicator parameters have exceeded threshold levels.

GWQAs for all four units were performed from 1988 to 1989 . The GWQAs characterized the extent, rate of migration, and concentration of hazardous waste and hazardous waste constituents released from each unit. The investigation results indicated that several factors controlled groundwater flow and contaminant migration at the units: the thickness and hydraulic conductivity of the Gallia sand and Minford silt, the thickness and low vertical conductivity of the Sunbury shale, the presence of storm drains, and the low hydraulic conductivity of the Minford clay.

Based on the results of the GWQAs, quarterly assessment monitoring was initiated for the X-701B holding pond, X-749 south contaminated materials storage yard, and the X-231B southwest oil biodegradation plot. Although the GWQA for the X-616 liquid effluent control facility did not indicate the presence of contamination, contamination was detected in subsequent sampling; therefore, quarterly monitoring was also initiated.

Groundwater assessment networks for these units are designed to evaluate contaminant concentrations and movement of indicator parameters. The networks consist of monitoring wells with well screens located in either the Gallia sand or Berea sandstone. Monitoring wells screened in the Gallia sand were installed in the centers of plumes, at the edges of plumes, and downgradient of plumes. Monitoring wells screened in the Berea sandstone were installed below plumes. Results obtained from chemical analyses of samples from these wells (1) indicate maximum concentrations of contaminants, (2) detect contaminants or quantify changes over time of the concentration of contaminants at the edges of plumes, (3) detect lateral migration of contaminants in the Gallia sand, and (4) detect downward migration of contaminants through the Sunbury shale and into the Berea sandstone.

Surface water monitoring is conducted in conjunction with groundwater assessment monitoring to determine if the contaminated groundwater has reached surface water. Surface water monitoring sites and their associated discharge points (see Fig. 7.6) are:

- Little Beaver Creek sample locations (LBC-SW01 to LBC-SW04), which assess X-701B groundwater collection french drains and water treatment facility discharges.

- Little Beaver Creek sample locations (LBC-SW01 to LBC-SW04), which assess X-701B groundwater collection french drains and water treatment facility discharges. 
ORNL-DWG 94M-9531

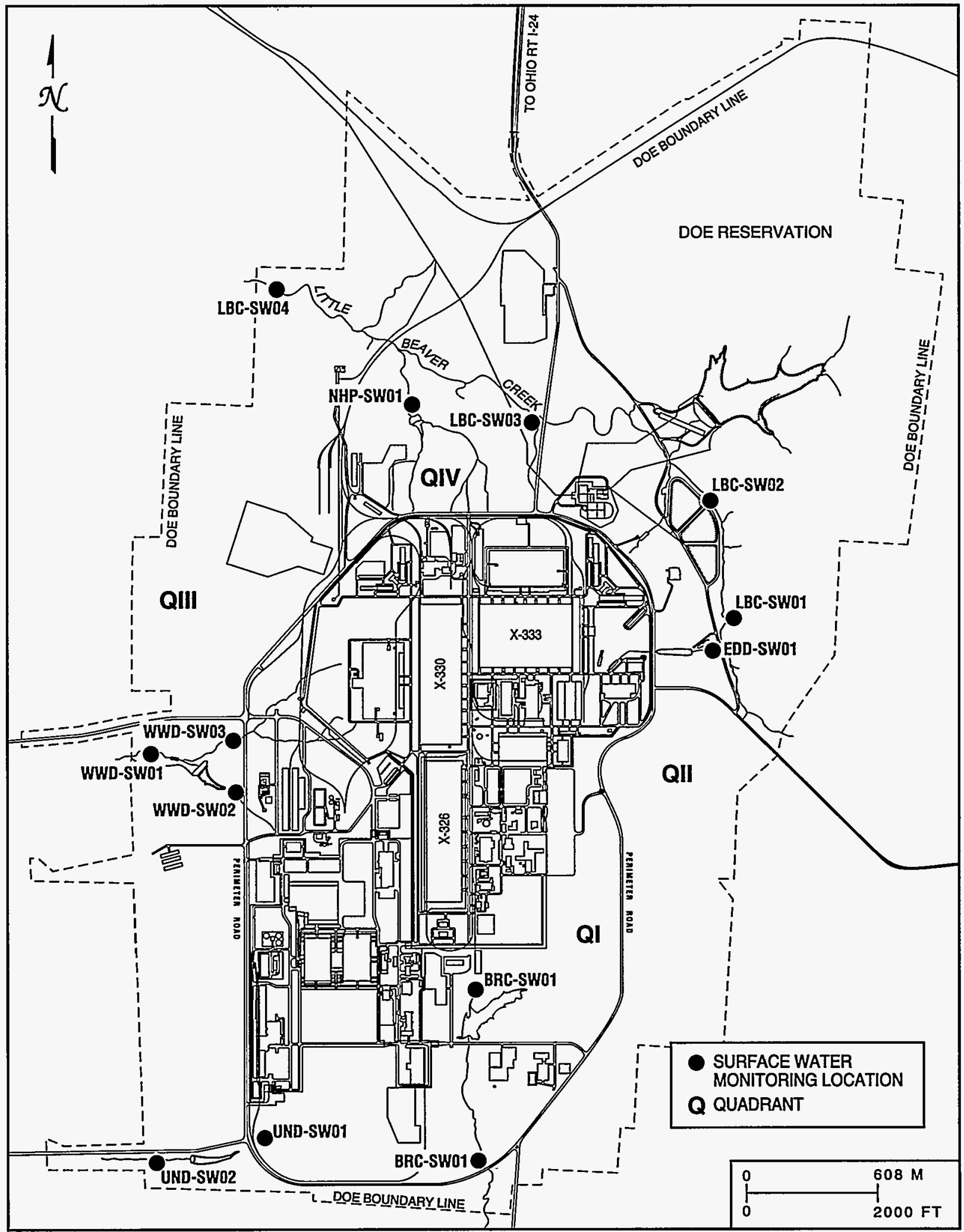

Fig. 7.6. Site-wide surface water monitoring locations. 
- The unnamed southwest drainage ditch at the southwest corner of Portsmouth (UND-SW01 and UND-SW02) and Big Run Creek (BRC-SW01 and BRC-SW02) sample locations, which assess the X-749 south contaminated materials storage yard. Big Run Creek sample locations also provide assessment for the $\mathrm{X}-231 \mathrm{~B}$ southwest oil biodegradation plot.

- West drainage ditch sample locations (WDD-SW01 to WDD-SW03), which assess X-616 liquid effluent control facility discharges.

- The X-230L north holding pond (NHP-SW01).

\section{X-701B Holding Pond}

The X-701B holding pond (see Fig. 7.7) is a group of unlined ponds consisting of a holding pond and the east and west retention basins. The holding pond was used from the beginning of plant operation in 1954 until November 1988. The pond was designed for neutralization and settlement of acid waste from several sources, including the $\mathrm{X}-701 \mathrm{C}$ neutralization pit (which receives waste from the $\mathrm{X}-700$ chemical cleaning building), the X-705 decontamination building, the X-710 laboratory, the X-720 maintenance building (Fig. 7.6), and the X-710 technical services building. Most wastes discharged to the X-701B holding pond were acid wastes, although degreasing solvents, including TCA and TCE, were also discharged to the pond.

In 1974 slake lime was added to the waste streams to neutralize the acid and to induce precipitation of radionuclides. The accumulated sludge was dredged annually and placed in the east retention basin from 1974 to 1980. After 1980 the sludge was placed in the west retention basin. Like the holding pond, these retention basins were unlined and did not have a leachate collection system.

\section{Groundwater Investigations}

Several groundwater investigations have occurred at this unit as well as installation of 74 groundwater monitoring wells: 8 wells are screened in the Minford clay/silt, 57 in the Gallia sand, 1 in the Sunbury shale, and 8 in the Berea sandstone. Twenty-one wells have been selected for quarterly assessment sampling. The samples are analyzed for parameters given in Table 7.2.

\section{Groundwater Flow}

The primary pattern of groundwater movement in the Minford clay/silt is vertically downward. Approximately $80 \%$ of the water entering the Minford clay/silt moves downward to the Gallia sand.

The primary pattern of groundwater movement in the Gallia sand is horizontal. Groundwater in the Gallia sand near X-701B holding pond flows radially from a groundwater mound located about $1200 \mathrm{ft}$ north of the holding pond. Groundwater flows from the mound southward under the X-701B holding pond and then turns eastward toward Little Beaver Creek. A groundwater divide is located just west of the holding pond, indicating that all groundwater in the X-701B holding pond area discharges either to Little Beaver Creek, the X-230J7 east holding pond, or the east drainage ditch (see Fig. 7.7).

Calculated groundwater flow velocity ranges from 0.8 to $1.6 \mathrm{ft} /$ day. The hydraulic conductivity of the Gallia sand is higher near the X-701B holding pond and decreases toward Little Beaver Creek. The hydraulic gradient is lowest near the X-701B holding pond but increases in the same direction that the hydraulic conductivity decreases so that the groundwater velocity remains nearly constant.

Practically all inflow to the Sunbury shale migrates vertically downward to the Berea sandstone, although this is only $2.4 \%$ of the water that enters the Gallia sand. Groundwater flow velocities calculated for the Sunbury shale are much lower than those for the Gallia sand or Berea sandstone. This is consistent with field observation of thick, competent shale in the vicinity of the X-701B holding pond.

The groundwater flow direction in the Berea sandstone, toward Little Beaver Creek, is the same as it is for the other geologic units in the vicinity of the X-701B holding pond. However, groundwater in the Berea sandstone does not discharge to Little Beaver Creek because the Sunbury shale is an upper confining bed for the Berea sandstone and the Berea sandstone is not exposed at the creek. 
ORNL-DWG 94M-9527

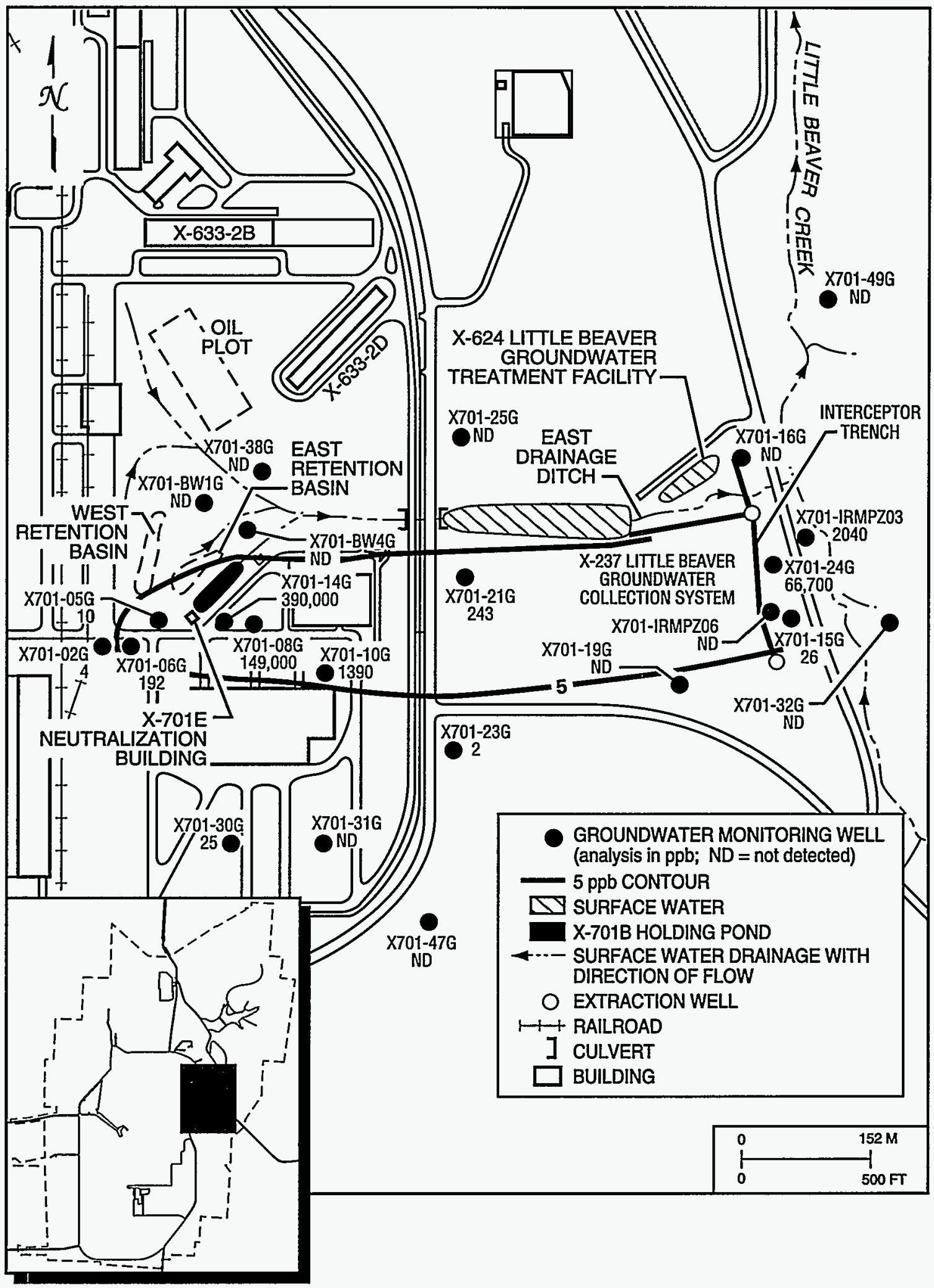

Fig. 7.7. X-701B holding pond-extent of trichloroethylene concentration, 4th quarter 1993. 


\section{Extent of Contamination}

Groundwater contamination in the Gallia sand is characterized by a long, narrow plume of mixed organic and radioactive constituents; the plume extends from the X-701B holding pond to Little Beaver Creek (Fig. 7.7).

TCE has migrated farther than any other contaminant and defines the extent of contamination. Contaminant plumes for other constituents have a pattern similar to that for TCE. Other VOCs of concern at the X-701B holding pond include 1,1,1-TCA and 1,1-dichloroethene (DCE). The following is a summary of contaminant plume information:

- Contaminant migration is initially to the southeast and then shifts to the east (toward Little Beaver Creek), corresponding to the location of thick but narrow deposits of Gallia sand.

- Groundwater flow converges from both the north and south, forcing a narrowing of flow.

- Contamination has been detected in samples from Little Beaver Creek and the east drainage ditch.

- No contamination has been detected east of Little Beaver Creek.

- No TCE has been detected in the Berea sandstone.

A qualitative evaluation of benthic fauna, conducted in 1991, indicated that species of pollution-sensitive macroinvertebrates (e.g., Ephemeroptera, Trichoptera, and Plecoptera) were absent and that pollution-tolerant taxa (e.g., Diptera and Chironomidae) were abundant. The benthic fauna were reevaluated in 1992; results were similar to those for 1991. Subsequent surface water sampling in the east drainage ditch revealed that the TCE plume from the X-701B holding pond was discharging into the east drainage ditch below the X-230J7 east monitoring facility holding pond embankment. As a result, further analysis of the groundwater flow regimes was conducted and an improved groundwater flow model was developed.

\section{Remediation}

Interceptor trenches and extraction wells in the interceptor trenches have been installed near Little Beaver Creek and the east drainage ditch to capture contaminated groundwater. The primary interceptor trench is situated parallel to the west bank of Little Beaver Creek and intercepts the TCE plume that could possibly enter Little Beaver Creek. The secondary interceptor trench is situated parallel to the south bank of the east drainage ditch and intercepts the TCE plume that could possibly enter the east drainage ditch. Interceptor trench locations and the extent of the TCE contamination plume are shown in Fig. 7.7. The lower part of the interceptor trenches are backfilled with gravel to facilitate flow, while the upper part is backfilled with clean soil. The primary trench is $660 \mathrm{ft}$ long and has two extraction wells completed in the backfill; the secondary trench is $440 \mathrm{ft}$ long and intersects the primary trench.

In 1993 about 5.4 million gal of groundwater was extracted from the trenches. The extracted water is treated using activated carbon filters and an air stripper at the X-624 groundwater treatment facility. Approximately $89 \mathrm{gal}$ of TCE was removed. The operation of this system stops migration of the contaminant plume toward Little Beaver Creek and the east drainage ditch.

\section{X-749 South Contaminated Materials Storage Yard}

Operation of the X-749 south contaminated materials storage yard began in the 1950s. No detailed records of wastes deposited in the landfill were kept until after 1976. Records kept from 1976 to 1990 indicate that deposited wastes consisted of $85 \%$ scrap materials and $15 \%$ containerized solids. Typically, wastes were placed in trenches approximately 12 to $15 \mathrm{ft}$ deep and were then covered with earth.

\section{Groundwater Investigations}

Several groundwater investigations that included installation of groundwater monitoring wells have occurred at this unit. A total of 61 wells have been installed: 5 wells screened in the Minford clay/silt, 44 in the Gallia sand, 1 in the Sunbury shale, and 11 in the Berea sandstone (Fig. 7.8). 
ORNL-DWG 94M-9528

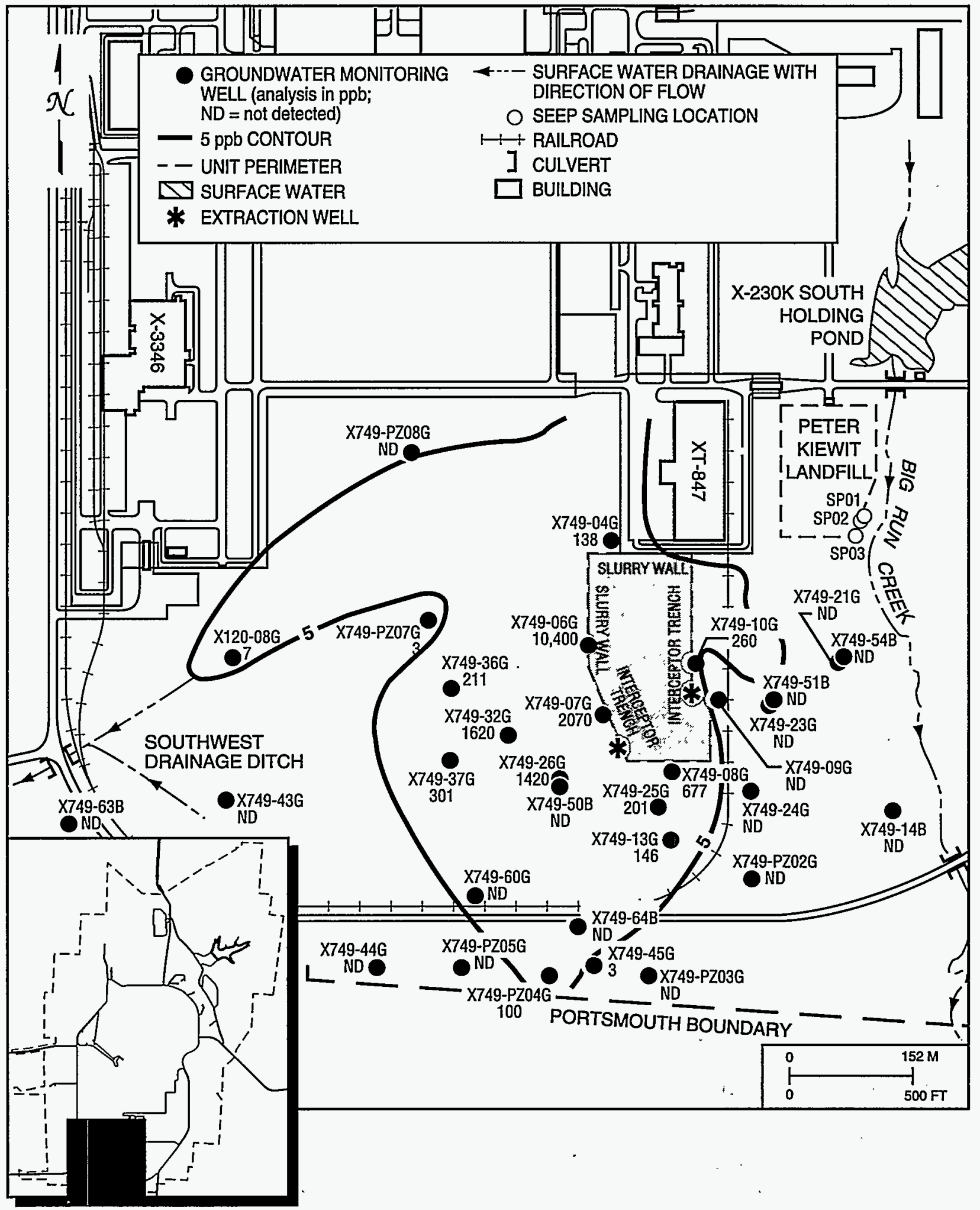

Fig. 7.8. X-749 south contaminated materials storage yard-extent of trichloroethylene concentration, 4 th quarter 1993. 
In addition to quarterly assessment monitoring, field investigations were conducted in 1992 and 1993 . The work included 75 Geoprobe borings, 21 piezometer or monitoring well installations, 2 synoptic water level measurements, 27 slug tests, continuous water level recording at 3 well clusters, groundwater sampling and analysis at 15 wells, digging of 12 test pits, and 2 pumping tests. This six-month long investigation defined the nature and extent of groundwater contamination and the hydrogeologic characteristics of the shallow waterbearing zone and provided data to support the evaluation and selection process for the interim measure alternative.

\section{Groundwater Flow}

The primary pattern of groundwater movement in the Minford clay/silt is vertically downward. Approximately $80 \%$ of the surface water entering the Minford clay/silt travels downward to the Gallia sand.

East of the X-749 south contaminated materials storage yard, near Big Run Creek, approximately $76 \%$ of the groundwater entering the Gallia sand flows horizontally, the remainder migrates vertically downward. The vertical component predominantly migrates directly to the Berea sandstone because the Sunbury shale is either thin or absent in this area and has been completely eroded by Big Run Creek.

The direction of horizontal flow is affected by the presence of groundwater divides. North-south trending groundwater flow divides are present in both the Gallia sand and the Berea sandstone. The divide in the Gallia sand is situated near the western boundary of the unit: groundwater flowing east from the divide migrates toward Big Run Creek; groundwater flowing to the west migrates toward the unnamed southwest drainage ditch and to the south toward the Portsmouth boundary.

Two pumping tests in the Gallia sand have been conducted at the X-749 south contaminated materials storage yard. Hydraulic conductivity values determined from pumping test data range from 4.13 to $5.98 \mathrm{ft} /$ day. Groundwater velocities calculated from using these hydraulic conductivity values range from $0.06 \mathrm{ft} /$ day to less than $0.6 \mathrm{ft} /$ day. Groundwater flow velocity is relatively constant in the Gallia sand throughout the area of this unit. A decrease in the hydraulic conductivity from the X-749 south materials storage yard toward Big Run Creek is compensated by a rapid drop in elevation over this same distance; this results in higher hydraulic gradients towards the east. Gallia sand potentiometric surface elevations average 8 to $15 \mathrm{ft}$ higher than those of the Berea sandstone. Hydraulic conductivity values for the Sunbury shale, when present, are significantly lower than those for the Gallia sand and Berea sandstone.

The direction of groundwater flow in the Berea sandstone is very similar to that observed for the Gallia sand, except that the north-south trending divide in the Berea sandstone is farther west than the Gallia sand divide. Flow east of the divide migrates toward Big Run Creek; flow west of the divide migrates toward the unnamed southwest drainage ditch. The average groundwater linear velocity in the Berea sandstone is $0.015 \mathrm{ft} /$ day. The area of higher Berea sandstone groundwater velocity is east of the X-749 south contaminated materials storage yard, where the Sunbury shale has been eroded.

\section{Extent of Contamination}

Although 18 wells were selected for quarterly assessment sampling, 25 wells were monitored all four quarters of 1993 because of apparent contaminant plume migration. Samples were analyzed for parameters listed in Table 7.2. The most extensive and most concentrated VOCs at the X-749 south contaminated materials storage yard were TCE and TCA. Other VOCs detected were 1,1-dichloroethane (DCA), DCE, 1,2-DCE, chloroform, and Freon-113. All contaminants were generally lower in concentration than, and contained within the extent of, the TCE plume.

The field work in 1992 and 1993 indicated that the TCE plume is closer to the Portsmouth boundary than was anticipated. The Gallia sand contamination (see Fig. 7.8) plume at the X-749 south contaminated materials storage yard extends about $1500 \mathrm{ft}$ to the south-southwest, about $1000 \mathrm{ft}$ to the south, and about $200 \mathrm{ft}$ to the southeast of the unit. The largest area of contamination extending to the south corresponds to the area where the Gallia sand deposits are thickest. In 1993 the X-749 interim remedial measure investigation was completed and the location of the southern edge of the VOC contamination plume was refined. TCE was detected within $55 \mathrm{ft}$ of the Portsmouth boundary. A regulatory-approved interim remedial measure alternative is a subsurface barrier that will divert the southern migration of groundwater and contaminant transport. 


\section{Remediation Measures}

The X-749 south contaminated materials storage yard has been closed according to RCRA requirements. Elements of the closure included

- installation of a multimedia cap,

- installation of a slurry wall along the north side and northwest corner of the unit,

- installation of subsurface groundwater drains on the northern half of the east side and the southwest corner of the unit, and

- one groundwater extraction well within each of the groundwater drains.

The slurry wall and subsurface drains extend down to bedrock. After collection, groundwater is pumped from the subsurface drains to an activated carbon filtration system at the X-622 groundwater treatment building (Fig. 7.9), where the groundwater is treated. The decontaminated water is discharged through the 003 National Pollutant Discharge Elimination System (NPDES)-permitted outfall.

\section{X-231B Southwest Oil Biodegradation Plot}

The X-231B southwest oil biodegradation plot was used from 1976 to 1983 for land application of waste oils and degreasing solvents and consists of two disposal plots, each surrounded by an elevated soil berm. The plots were periodically fertilized and disced to enhance aeration and promote natural biological degradation of waste oil. This unit has been capped with a temporary synthetic cover. In late 1993, vadose zone remediation was initiated.

\section{Groundwater Investigations}

Since 1985 several groundwater investigations and installations of monitoring wells have occurred. At the completion of the GWQA investigation, 35 monitoring wells were installed in the vicinity of this unit (see Fig. 7.9): 3 wells were screened in the Minford clay/silt, 25 in the Gallia sand, 1 in the Sunbury shale, and 6 in the Berea sandstone. Thirteen wells have been selected for quarterly assessment monitoring. Samples are analyzed for the chemical parameters listed in Table 7.2.

\section{Groundwater Flow}

The primary pattern of groundwater movement in the Minford clay/silt is vertically downward to the Gallia sand. Groundwater entering the Gallia sand at X-231B southwest oil biodegradation plot flows laterally, primarily to the southeast toward the X-230K south holding pond. Most groundwater remains in the Gallia sand and does not migrate downward into the Berea sandstone. The hydraulic gradient is very low because the $\mathrm{X}-231 \mathrm{~B}$ southwest oil biodegradation plot is located in an area where the bedrock is relatively flat; thick, permeable Gallia sand deposits are present; and the area is close to the east-west groundwater divide that runs through the Portsmouth site. The vertical hydraulic gradient from the Gallia sand to the Berea sandstone is steep and has an average potentiometric difference of 8 to $10 \mathrm{ft}$; approximately $1 \%$ of the water entering the Gallia sand migrates to the Berea sandstone.

The hydraulic conductivity of the Gallia sand is $41.0 \mathrm{ft} /$ day, and the average flow velocity is $1.2 \mathrm{ft} /$ day. The Gallia sand is thin, generally less than $1.2 \mathrm{ft}$ thick, below the X-231 southwest oil biodegradation plot. More extensive Gallia sand deposits occur to the southeast and east of the unit. The average groundwater velocity for the Gallia sand is approximately $0.90 \mathrm{ft} /$ day.

The hydraulic conductivity of the Sunbury shale is significantly lower than the hydraulic conductivity of the Gallia sand. Therefore, the downward vertical migration of groundwater from the Gallia sand to the Berea sandstone is impeded.

Groundwater in the Berea sandstone flows to the southeast. The flow system is not similar to that in the Gallia sand because of the presence of relatively thick ( $8 \mathrm{ft}$ or more) Sunbury shale. Surface drainage influences 


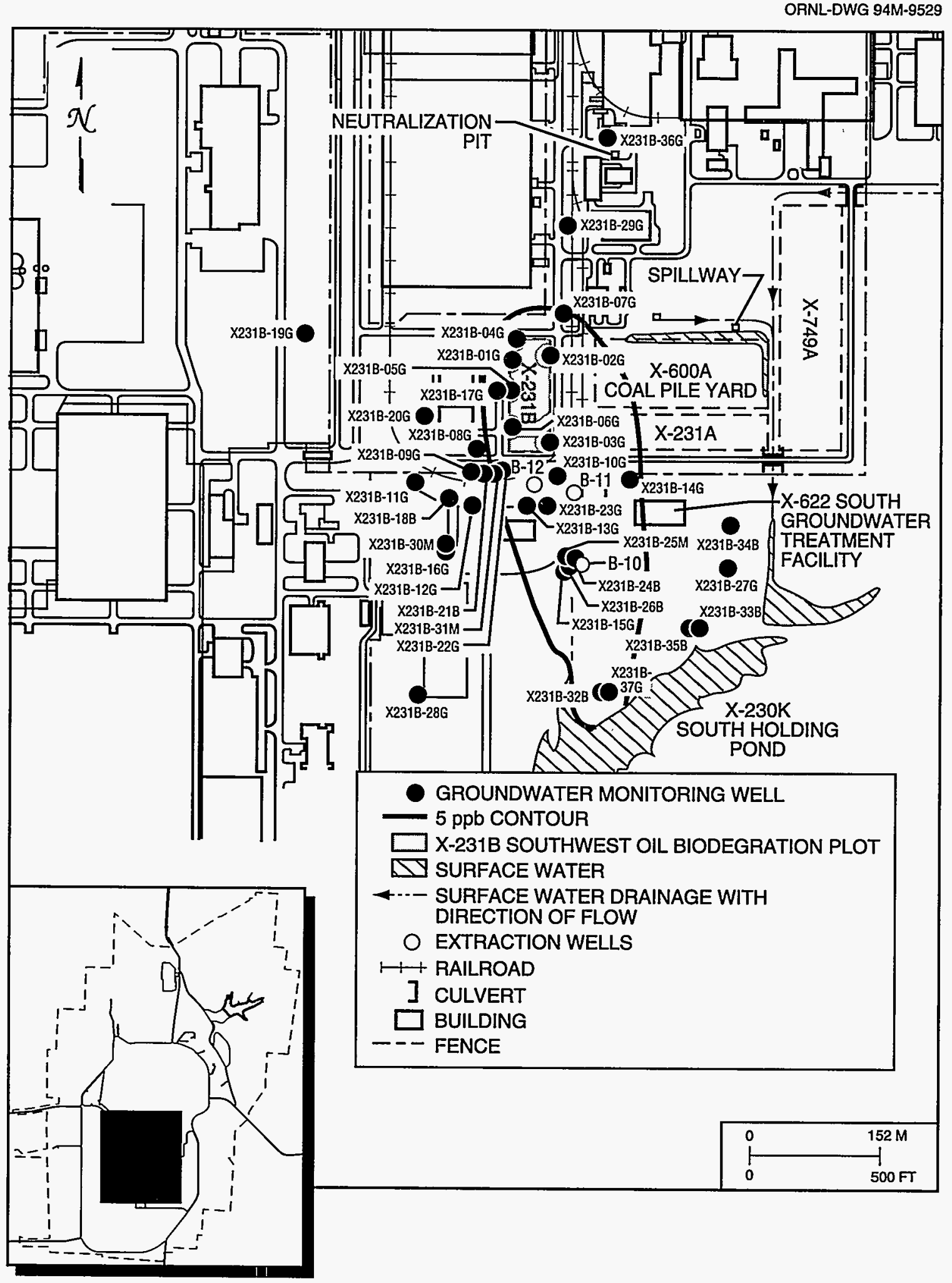

Fig. 7.9. X-231B southwest oil biodegradation plot monitoring well locations. 
the direction of groundwater flow in the Gallia sand but not in the Berea sandstone. The calculated average linear groundwater velocity for the Berea sandstone is $0.02 \mathrm{ft} /$ day.

Groundwater flow modeling predicts that groundwater movement from the X-231B southwest oil biodegradation plot is slow and eventually discharges to the $\mathrm{X}-230 \mathrm{~K}$ south holding pond (Fig. 7.9) in about 10 to 15 years.

\section{Extent of Contamination}

The VOC plumes at the X-231B southwest oil biodegradation plot are smaller in extent than those at the $\mathrm{X}-701 \mathrm{~B}$ holding pond and X-749 south contaminated materials storage yard. The plumes are narrow and elongated in the north-south direction. The Gallia sand contamination plume at the X-231B southwest oil biodegradation plot extends about $1000 \mathrm{ft}$ to the south toward the $\mathrm{X}-230 \mathrm{~K}$ holding pond. The northern boundary of the TCE plume is near the south end of the X-326 building. The areal extent of the TCE plume encompasses the areal extent of all other VOC plumes associated with X-231B oil biodegradation plot, and the levels of TCE are also higher than any other VOC.

\section{Remediation Measures}

As part of closure on this unit, three groundwater extraction wells were installed in the Gallia sand. These wells are located south of the unit and are aligned across the central portion of the TCE contaminant plume (shown in Fig. 7.9). This configuration prevents TCE dispersion.

\section{X-616 Liquid Effluent Control Facility}

The X-616 liquid effluent control facility (Fig. 7.10) consists of two unlined surface impoundments that were used from 1976 to 1985 for storage of sludge generated by treatment of recirculating cooling water blowdown from the Portsmouth process cooling system. A hexavalent chromium-based corrosion inhibitor was used in the cooling water system. The chromium in the blowdown was reduced to a trivalent chromium at the X-616 liquid effluent control facility by adding sulfur dioxide to the water, which produced sulfurous acid $\left(\mathrm{H}_{2} \mathrm{SO}_{3}\right)$. The resulting chromium hydroxide sludge was then precipitated in a clarifier by $\mathrm{pH}$ adjustment with slaked lime and a polymer coagulant. The sludge was pumped to the X-616 impoundments, where it was stored.

From February to May 1987, treated process effluent from the X-700 chemical cleaning facility, via the $\mathrm{X}-701 \mathrm{C}$ neutralization pit, was diverted to the X-616 liquid effluent control facility to reduce the high concentration of suspended solids discharged from the X-701B holding pond. In addition, chlorinated organic solvents were discovered in the X-700 chemical cleaning facility basement sump that discharges to the X-701C neutralization pit.

\section{Groundwater Investigations}

Since 1978 groundwater investigations have been conducted and monitoring wells have been installed at the $\mathrm{X}-616$ liquid effluent control facility. During the GWQA study for the X-616 liquid effluent control facility, 22 groundwater monitoring wells were sampled. Some VOCs were found in isolated wells at concentrations below $10 \mathrm{ppb}$. In November 1989, four wells were sampled for RCRA Appendix IX analytes and elevated levels of total chromium were detected. In 1990 quarterly sampling for chromium was conducted at 12 wells. The results indicated that some total chromium results exceeded regulatory limits. Upon completion of the GWQA, 28 monitoring wells were installed in the vicinity: 3 in the Minford clay/silt, 20 in the Gallia sand, and 5 in the Berea sandstone (Fig. 7.10).

During this time, the X-616 liquid effluent control facility was undergoing a clean closure according to RCRA requirements. A review of all groundwater data showed that TCE had been detected at low levels (less than $30 \mathrm{ppb}$ ) in monitoring wells not included in the 12-well monitoring network; therefore, a clean closure could not be certified. Two wells at which TCE had been detected were added to the monitoring well network. When TCE was detected in these two wells, an adjacent well was added to the monitoring well network.

In 1991 groundwater samples were monitored for VOCs, radiological parameters, and five unfiltered metals. In 1992 the five metals were analyzed for in both filtered and unfiltered samples. In 1993 common anions and 


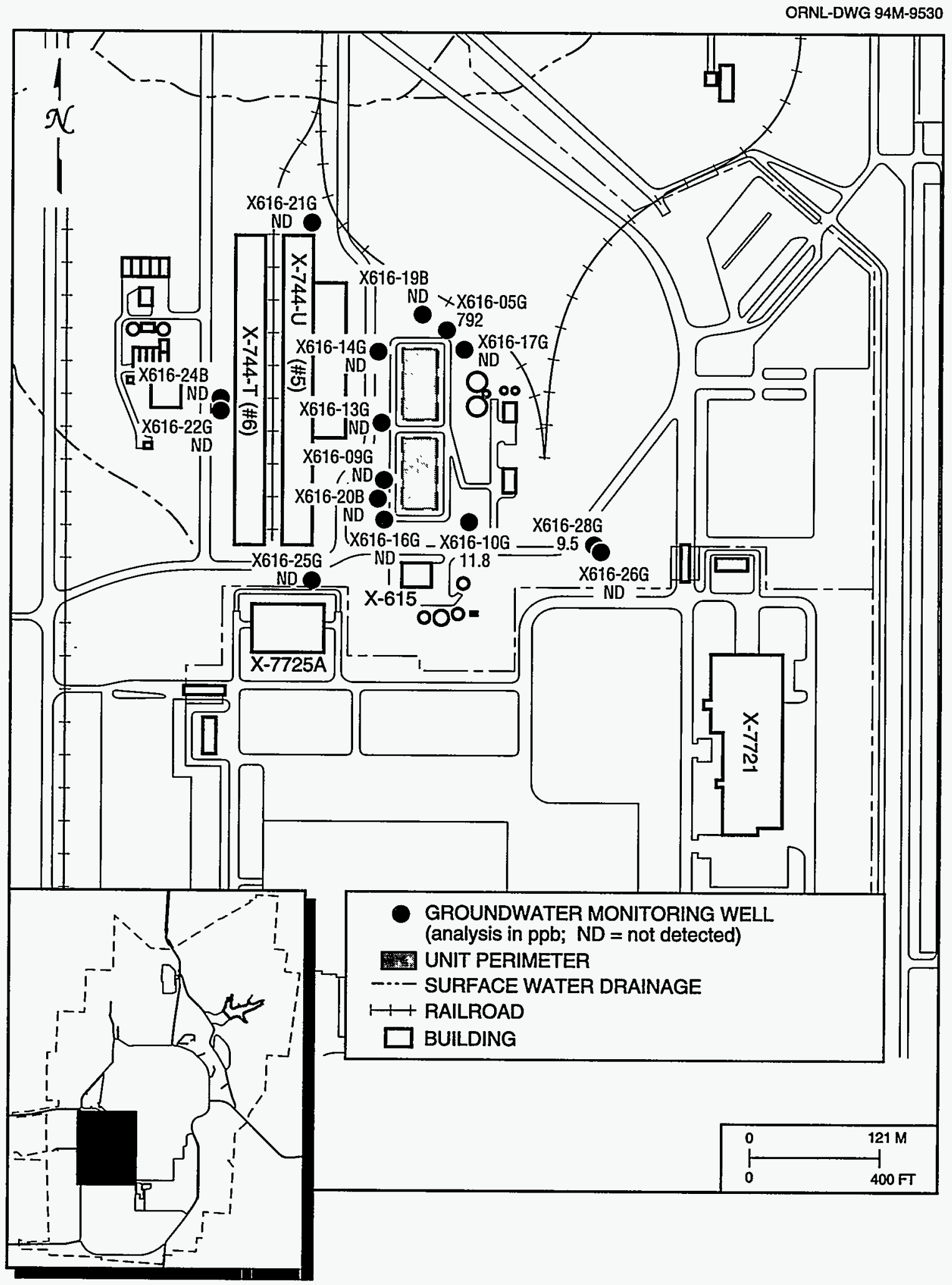

Fig. 7.10. X-616 chromium sludge surface impoundments-extent of chromium (SW846/Diss.) concentration, 1 st quarter 1993. 
cations were added to the list of analytes (see Table 7.2). Concentrations of chromium will be compared with background levels of chromium determined from off-site sampling to be completed in 1994.

\section{Groundwater Flow}

At the X-616 liquid effluent control facility, the Gallia sand is 4 to $6 \mathrm{ft}$ thick and thins in all directions away from the surface impoundments. The Sunbury shale is absent under the X-616 liquid effluent control facility, so the Gallia sand overlies the Berea sandstone. Hydraulic conductivity in the Gallia sand is about $4.6 \mathrm{ft} /$ day, and groundwater velocity ranges from 0.17 to $0.28 \mathrm{ft} /$ day. Before closure, groundwater flow from the site was reported as being radial. Since closure, groundwater flow in the Gallia sand has changed to a predominantly west-northwest direction toward local drainage channels of the west drainage ditch.

Groundwater flow in the Berea sandstone is primarily to the northwest. Groundwater in both the Gallia sand and the Berea sandstone flows away from the X-616 liquid effluent control facility through two forks of the west drainage ditch to the X-230J5 holding pond. The average Berea sandstone hydraulic conductivity in the vicinity of the X-616 liquid effluent control facility is $0.35 \mathrm{ft} /$ day, which is higher than that measured at the other assessment monitoring units. Because the Sunbury Shale is absent, the Gallia and Berea are in direct hydrologic communication. Groundwater flow modeling predicts that groundwater from both the Gallia sand and the Berea Sandstone discharges to the west discharge ditch, with an estimated groundwater travel time in excess of 30 years for both.

\section{Closure Activities}

Closure activities at the X-616 liquid effluent control facility in 1991 included dewatering, removing the chromium sludge, and backfilling the ponds with clean fill. Post-closure monitoring of this unit began in 1994.

\section{Groundwater Surveillance Monitoring}

The surveillance monitoring program at Portsmouth consists of perimeter exit pathway monitoring, off-site water supply sampling, and Portsmouth water supply well field sampling. Perimeter monitoring assesses the effect of the facility on regional groundwater quality and quantity. Off-site sampling and Portsmouth water supply well field sampling address concerns about the impact of Portsmouth operations on the quality of the drinking water supply. Baseline monitoring is also conducted.

\section{Exit Pathway Monitoring}

Groundwater investigations have determined that the Gallia sand is the primary hydrogeologic unit for contaminant migration at Portsmouth. The Gallia sand is not a regionally persistent unit because of the topography on which it was deposited, as well as its depositional environment. Selected locations on local streams and drainage channels near the reservation boundary are sampling points of the surveillance monitoring program because groundwater discharges to these surface waters. Monitoring wells near the reservation boundary are also used in the surveillance monitoring program. Figure 7.11 shows the sampling locations for exit pathway monitoring.

\section{Off-Site Sampling}

The purpose of the off-site well sampling program is to ensure that drinking water sources have not been adversely affected by Portsmouth operations. Although this program may provide an indication of contaminant transport off-site, it should not be interpreted as an extension of the on-site groundwater monitoring program, which bears the responsibility for detecting contaminants and determining the rate and extent of contaminant movement. Because little is known about how residential wells were constructed and about the pumps used in residential wells, data from this program will not be used in hydrogeologic or geochemical investigations.

Currently, nine residents are participating in the program (see Fig. 7.12 for sampling locations and Table 7.2 for the analytical parameters). All sampling for the residential program is conducted semiannually. Sampling locations are added or deleted as residents' requests and program requirements dictate. Typically, sampling 


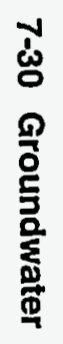

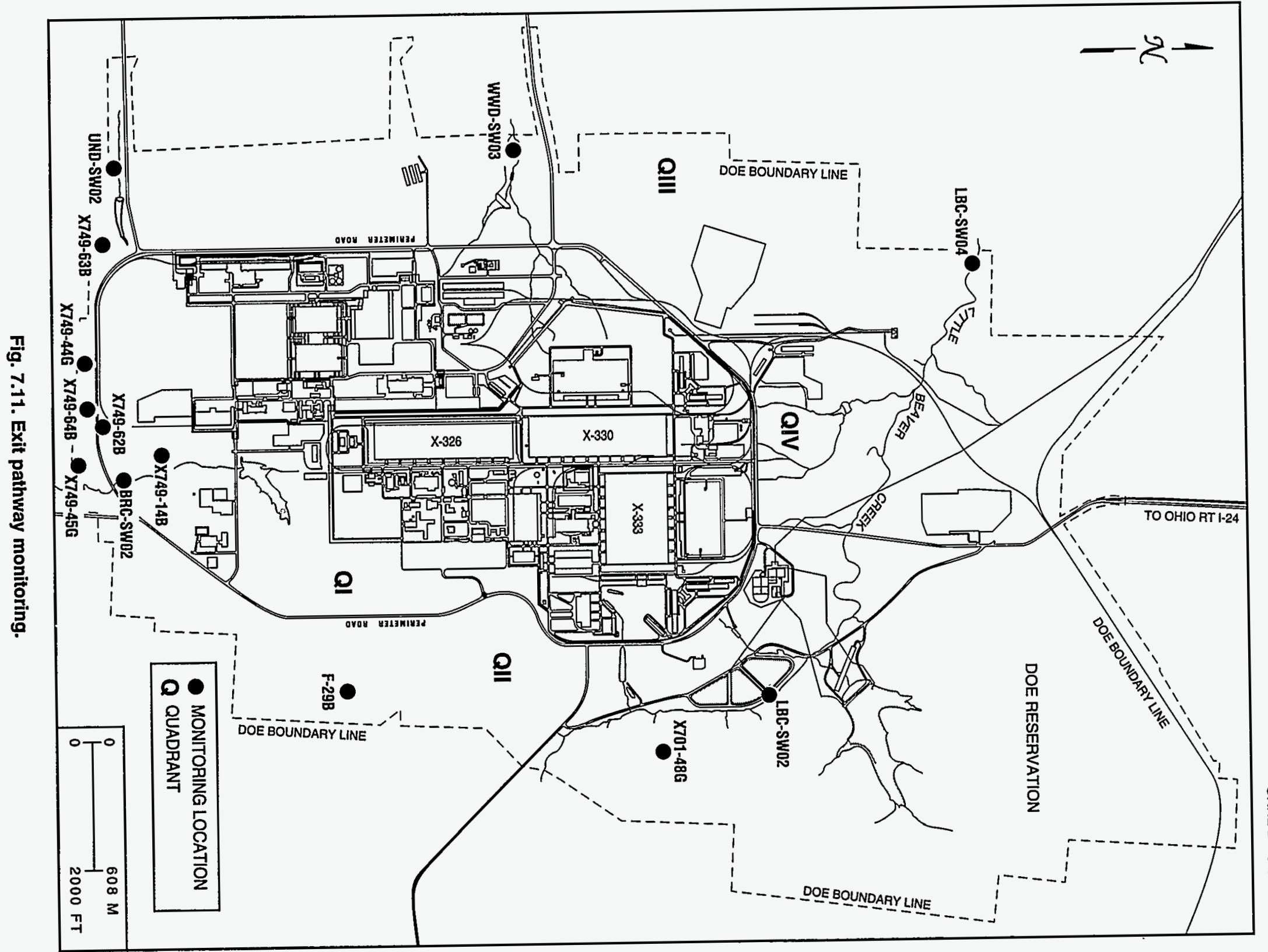


ORNL-DWG 94M-9533

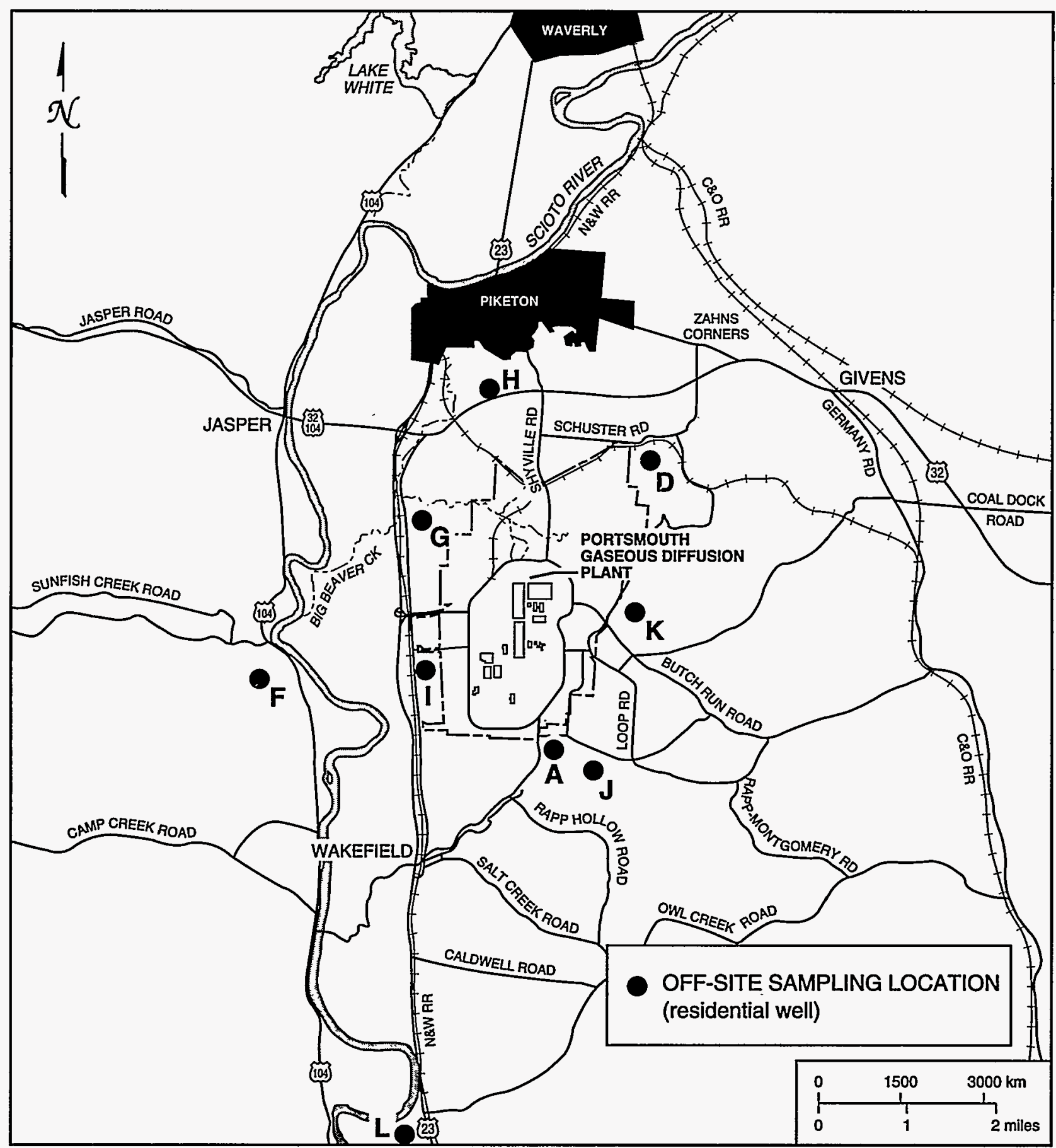

Fig. 7.12. Off-site well sampling locations. 
locations are deleted when a resident obtains access to the public water supply. Sampling locations are added on request and if there is a probable hydrogeologic connection between Portsmouth and a resident's water supply.

\section{Portsmouth Water Supply Well Field Sampling}

The water supply for Portsmouth is provided by the X-605G, X-608B, and X-6609 well fields that are located along the east side of the Scioto River about 0.9 to 4.5 miles west of Portsmouth (Fig. 7.13). At any given time, approximately $25 \%$ of the wells are out of service because of scheduled or unscheduled maintenance. Portsmouth water demands are met by pumping the remaining in-service wells from all three well fields.

Selected Portsmouth water supply wells are sampled semiannually. If the wells to be sampled are out of service during the sampling period, designated alternates are sampled. The original and alternative sampling wells are listed in Table 7.2.

\section{Baseline Monitoring}

Four well clusters, each composed of one well completed in the Gallia sand and one well completed in the Berea sandstone, are sampled semiannually to determine baseline water quality (Fig. 7.14). Sampling is conducted to support the next RCRA permit application and to provide a comparison between on-site wells and off-site background water.

\section{Other Investigations}

Three other groundwater or groundwater-related investigations occurred in 1993: (1) Peter Kiewit landfill seep sampling, (2) UST assessments, and (3) the X-737 proposed sanitary landfill hydrogeology investigation.

\section{Peter Kiewit Landfill}

The Peter Kiewit landfill is located west of Big Run Creek just south of the X-230K holding pond (Fig. 7.8). The landfill, opened in 1952, was used as the salvage yard, burn pit, and trash area during construction of Portsmouth. After the initial construction, the disposal site was operated as a sanitary landfill until 1968, when soil was distributed over the site and graded and the area was seeded with native grasses. No manifests or records exist that characterize the material in the landfill. In addition, construction details and operation records are not available.

Groundwater seeps have been identified along the southeast corner of the landfill. The approximate flow rate ranges from 300 to $570 \mathrm{gal} /$ day. Environmental sampling occurs at three of the seeps and at Big Run Creek, about $40 \mathrm{ft}$ downstream of the seeps. The primary contaminant of concern is vinyl chloride, which was first during Quadrant I RFI sampling. The most recent laboratory analyses indicate that the level of vinyl chloride in the seep samples is above the values reported in the draft of the Quadrant I final RFI report.

The vinyl chloride concentration of the seeps ranges from 20 to $104 \mathrm{ppb}$. However, the vinyl chloride concentration in the sample from Big Run Creek just downstream from the seeps is less than the detection limit of $1 \mathrm{ppb}$. After confirmation of contaminants in the seeps, sampling was conducted weekly for eight weeks. Current sampling is conducted quarterly. Portsmouth is developing an interim remedial plan that will prevent contaminant seepage into Big Run Creek.

\section{UST Investigations}

Two site assessments were performed in 1993: (1) at the X-1107DV portal and (2) at the X-750 building (Fig. 7.15). The assessments were performed to determine whether soil and groundwater are contaminated with petroleum products at levels that require corrective action. All work was done in compliance with the State Fire Marshal's Bureau of Underground Storage Tank Regulations (BUSTR), OAC 1301:7-9-13. Field activities consisted of putting in upgradient and downgradient soil borings, installing upgradient and downgradient monitoring wells, performing organic and radiological field screening of soil samples, obtaining water-level measurements, and performing chemical analyses on the groundwater and soil samples. Monitoring wells were screened across the water table.

\section{7-32 Groundwater}


ORNL-DWG 94M-9534

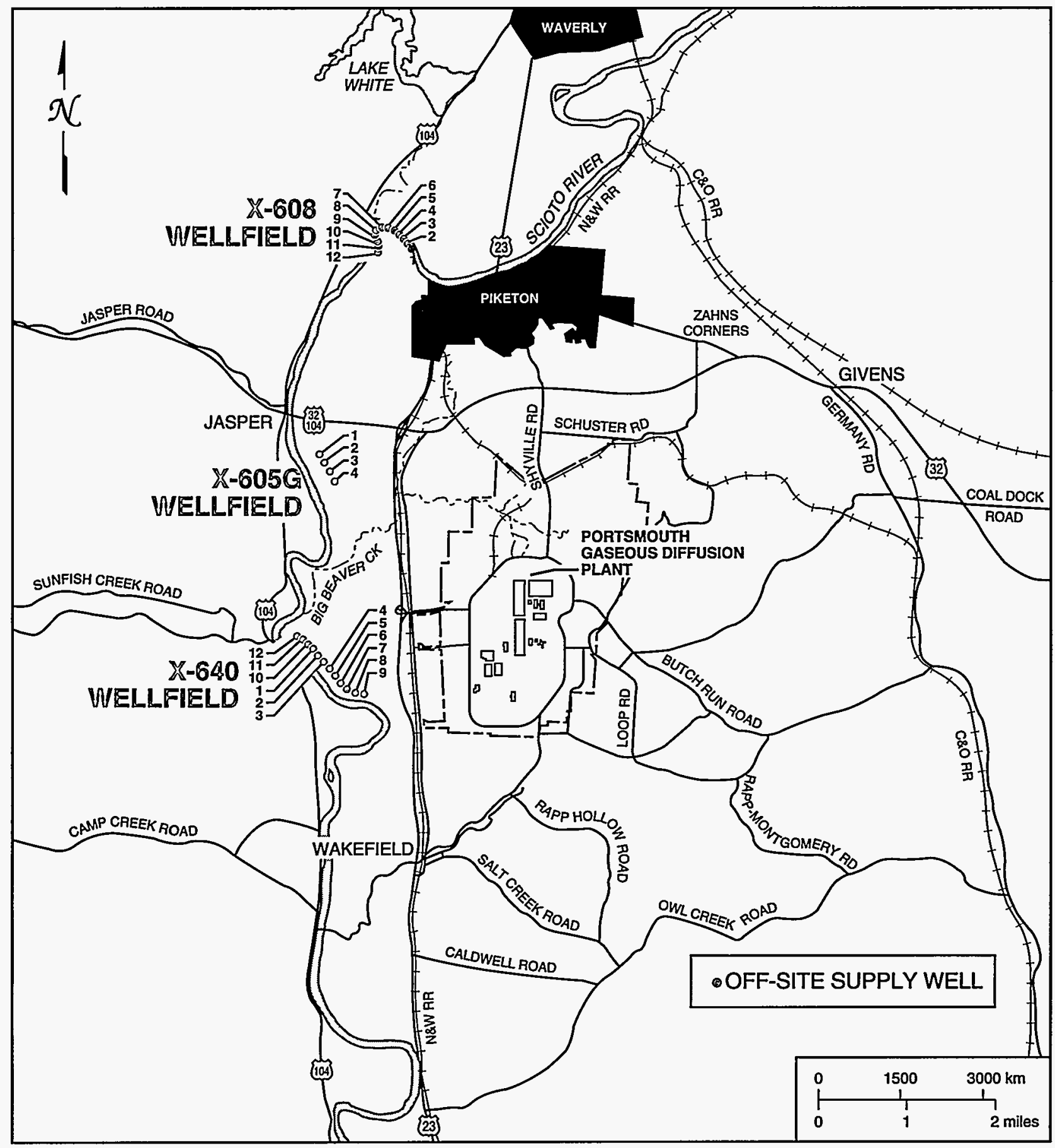

Fig. 7.13. Portsmouth water supply well field sampling. 


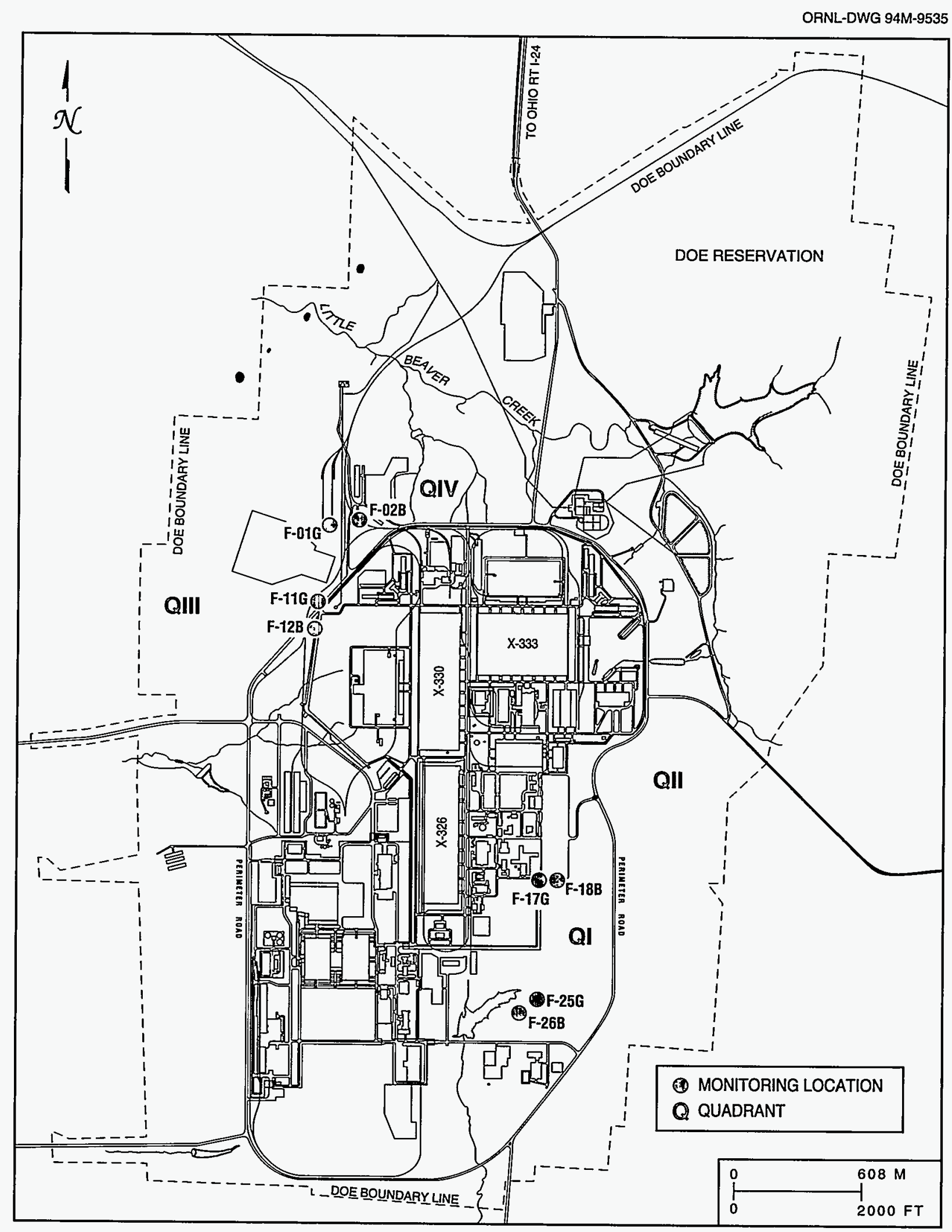

Fig. 7.14. Baseline well monitoring locations. 


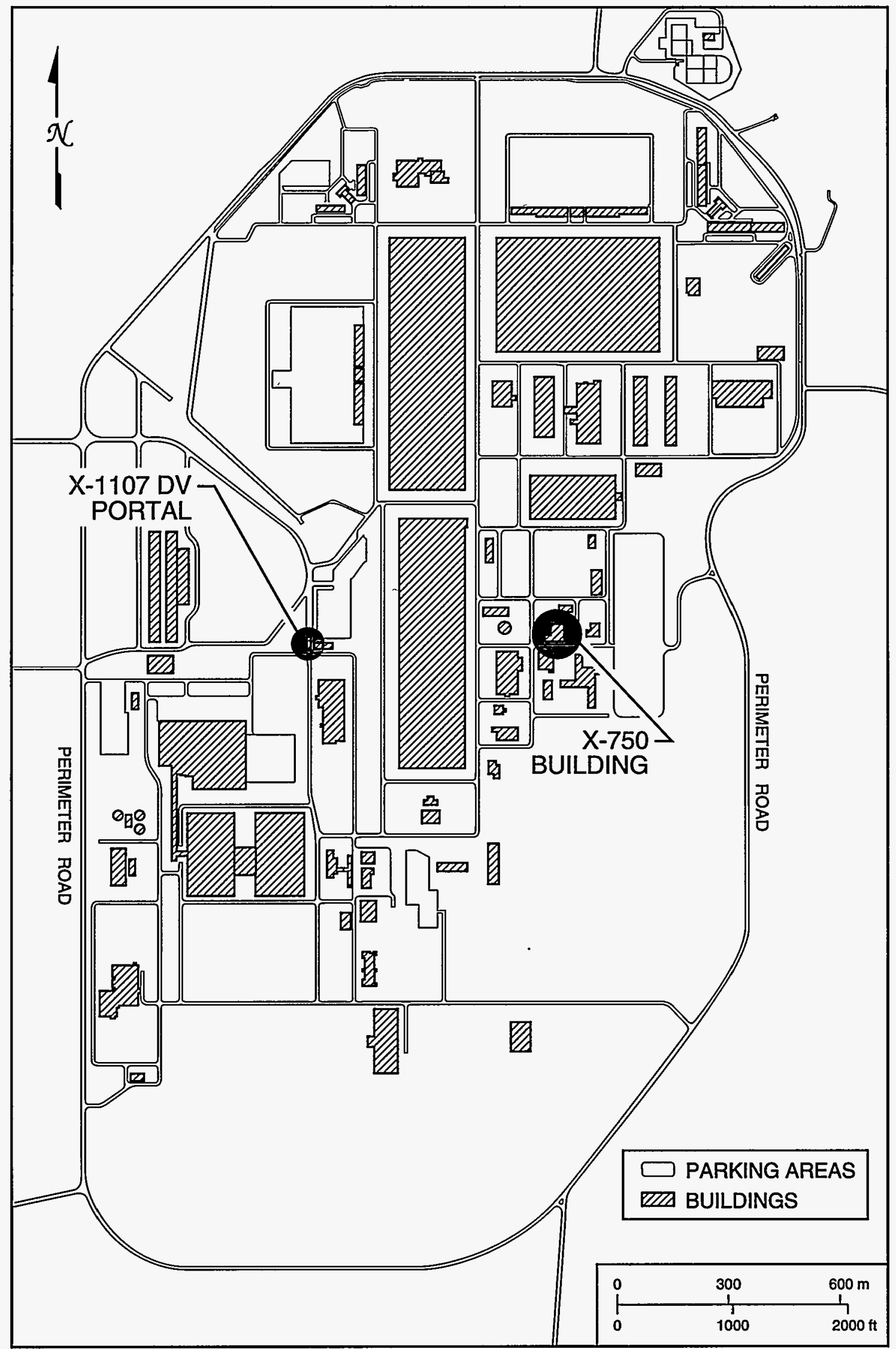

Fig. 7.15. UST investigations. 


\section{X-1107DV Portal UST Investigation}

The X-1107DV portal is a Portsmouth access control point (Fig. 7.15). At this location, a 500-gal fiberglass diesel UST failed a tightness test. A site check determined that petroleum hydrocarbons above the action level are present in the soil in the immediate vicinity (within $2 \mathrm{ft}$ ) of the UST; therefore, a site assessment was initiated.

For the assessment, a total of three soil borings were advanced 30 to $34 \mathrm{ft}$ below ground surface at the $\mathrm{X}-1$ 107DV portal and monitoring wells were installed in them. Soil samples were collected continuously from the ground surface to the termination of each boring. Groundwater samples were obtained from the monitoring wells. Field screening measurements for organic compounds were all less than 5 parts per million vapor (ppmv) above background readings for both soil and groundwater samples. No evidence of petroleum contamination was observed during the drilling, well installation, or sampling activities.

Seven soil samples and one groundwater sample from each of the wells were sent for laboratory analyses. No additional petroleum contamination was detected in the vadose, or saturated, zones of the unconsolidated sediments. Because contamination at the X-1107DV portal is of such limited extent, no further investigation is warranted.

\section{X-750 Building UST Investigation}

The X-750 building (Fig. 7.15) is the primary maintenance, fuel storage, and refueling station for Portsmouth mobile equipment. A 10,000-gal UST was removed from this location in 1991, and some surrounding soil was excavated during the tank removal. Soil and water samples from the pit were collected and sent for laboratory analysis. Because of safety concerns, the tank pit was backfilled before the sample analyses were received. The analyses indicated that fuel contamination was still present in the soil, so a site assessment was initiated.

Four soil borings were drilled into the Gallia sand to a depth of 30 to $35 \mathrm{ft}$ below ground surface at the X-750 building. Soil samples were collected continuously from the ground surface to the termination of each boring, and 12 samples were sent for laboratory analysis. Monitoring wells were installed in three of the four boreholes, and a groundwater sample from each well was also sent for. laboratory analysis.

No evidence of petroleum contamination was observed during the drilling, well development, or sampling activities. Except for one measurement, field screening for organic compounds performed on both soil and water samples were all less than 5 ppmv above background readings. The single field screening result above 5 ppmv was not confirmed by laboratory analysis of the sample.

During the UST and soil removal, the excavated petroleum-contaminated soil was removed and disposed of. Results of the site assessment indicate that no petroleum contamination migrated to nearby soil or groundwater.

\section{X-737 Landfill Investigation}

The X-737 landfill is the proposed location of a new sanitary landfill at the north end of the Portsmouth site (Fig. 7.16). The size of the proposed landfill is approximately 40 acres.

\section{Groundwater Investigations}

A hydrogeologic site investigation was conducted in 1993. Work conducted during this investigation fulfilled requirements specified in OAC 3745-27-06(C)(2), Solid Waste Disposal Regulations Permit To Install Application.

At this location, the combined thickness of the unconsolidated sediments composed of the Minford clay/silt and the Gallia sand is up to $43.8 \mathrm{ft}$. The Sunbury shale is absent, and the Berea sandstone forms the bedrock. Seven monitoring wells were installed in the unconsolidated sediments, and four monitoring wells were installed in the Berea sandstone. Eleven samples of unconsolidated sediments and four samples of the Berea sandstone were analyzed for parameters on the target compound list/target analyte list (TCL/TAL) and for radiological parameters. Geotechnical analyses were performed on three samples from the Berea sandstone. Slug tests were performed on seven of the groundwater monitoring wells: four in the unconsolidated sediments and three in bedrock. Groundwater samples were analyzed for TCL/TAL and radiological parameters. 


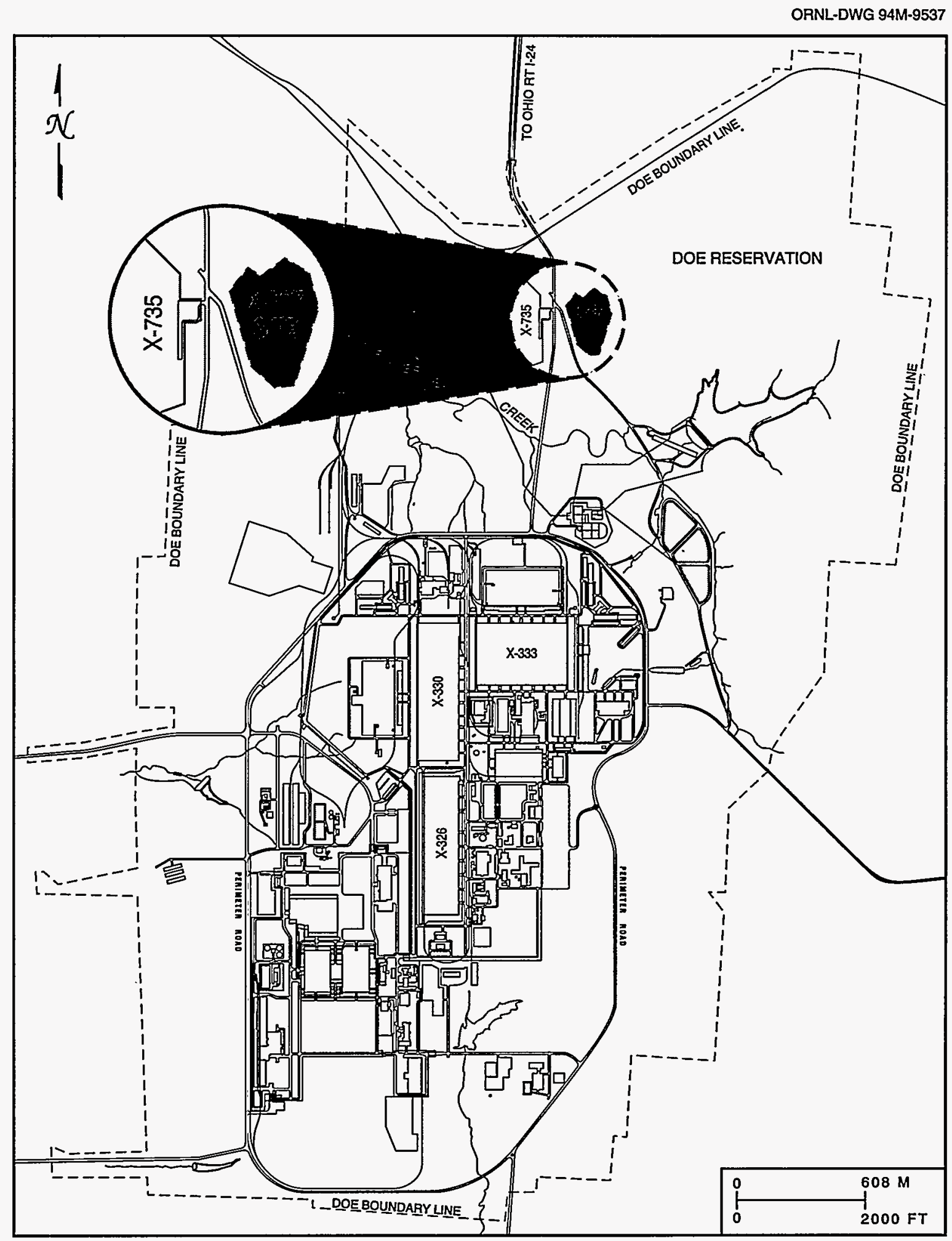

Fig. 7.16. X-737 proposed landfill. 


\section{Groundwater Flow}

Groundwater flow in the unconsolidated deposits is located in the lower Teays Fm., which is composed of the Minford silt and Gallia sand. The change from the Minford silt and Gallia sand is gradational, and the lithologic contact for the two cannot be distinguished. Therefore, for discussion of hydraulic conductivity, the Minford silt and Gallia sand will be considered as one hydrologic unit. Based on slug-test results, the hydraulic conductivity values for the lower Teays Fm. range from 3 to $5 \mathrm{ft} /$ day. Groundwater flow is to the west toward Little Beaver Creek and its tributary.

The Berea sandstone exhibits two hydraulic conductivities. The first is for unfractured Berea sandstone where groundwater flow is in the pore space of the formation. The unfractured rock hydraulic conductivity is $0.013 \mathrm{ft} /$ day. The second is where fractures are encountered and groundwater flow is in the fractures. In these cases, the Berea has the same $5 \mathrm{ft} /$ day hydraulic conductivity as the unconsolidated deposits. Groundwater flow in the Berea is to the west toward Little Beaver Creek and its tributary.

\section{RFI Quadrant Investigations}

The Consent Decree issued by the Ohio Attorney General's Office on August 29, 1989, and the RCRA, 3008(h), Consent Order issued by USEPA Region V on September 29, 1989, outline requirements and schedules for the RFI. These documents include specific dates and specifications for deliverables that must be complied with throughout the RFI, the corrective measures study, and corrective measures implementation.

Groundwater investigative activity is based on guidelines for a RCRA corrective action plan. However, because the Portsmouth site is large, complex, and resource intensive, the plan is being implemented in four parts called "quadrants." The quadrants divide the plant site into four geographic areas based roughly on groundwater divides and drainage patterns. These quadrants (QI, QII, QIII, and QIV) and associated drainages are indicated in Fig. 7.11. Parallel efforts to provide comprehensive definitions of geology and the hydrologic flow systems provide cohesiveness to this four-part approach.

Field work for quadrants I (QI) and II (QII) was completed in fall 1991. During the QI and QII RFIs, 103 monitoring wells were installed and 149 soil borings were drilled. The QI and QII RFIs provided separate investigations of 34 SWMUs. Contaminated groundwater plumes were discovered emanating from the following units: (1) the X-120 Goodyear Training Center (Fig. 7.8); (2) X-231A southeast oil biodegradation plot (Fig. 7.9); (3) X-710 neutralization pit (Fig. 7.5), X-710 "hot pit" and X-760 neutralization pit (Fig. 7.9); and (4) the X-700 chemical cleaning facility (Fig. 7.5), X-705 decontamination building (Fig. 7.5), and X-720 maintenance and stores building (Fig. 7.5).

A total of 18 SWMUs were investigated in the QIII RFI. As part of the investigation, 14 wells were installed, 44 soil borings and 93 hand augers were completed, 36 sediment samples were taken, and two surface water sampling sites were monitored. The results and conclusions of the report are included in the Quadrant $\mathrm{II}$ Draft Report dated December 1992. Additional sampling is scheduled to be completed in 1994 to support the RFI and the corrective measures study.

A total of 24 SWMUs were investigated in the QIV RFI. As part of this investigation, 49 wells were installed, 80 soil borings and 85 hand augers were completed, and 85 sediment samples were collected. The results and conclusions of the report are included in the Quadrant IV Draft Report dated August 1993. Additional sampling is scheduled to be completed in 1994 to support the RFI and the corrective measures study.

\section{X-120 Goodyear Training Center Contaminant Plume}

The X-120 Goodyear Training Center consists of several utility and storage buildings used during construction of Portsmouth in the 1950s. The plume associated with the X-120 Goodyear Training Center consists of TCE; 1200 ppb was the highest concentration detected. In 1989 TCE concentrations of 800 and $100 \mathrm{ppb}$ were detected in two groundwater wells at this location. Initially, this contamination was presumed to be associated with the X-749 south contaminated materials storage yard; however, results from the QI RFI indicated that the contamination is independent of the X-749 facility.

During the QI RFI, TCE was detected in four wells at concentrations ranging from 18 to $1200 \mathrm{ppb}$. The long and narrow TCE contaminant plume associated with the X-120 facility originates south of Hewes Street and 
extends approximately $1400 \mathrm{ft}$ to the southwest (Fig. 7.8); the southeastern edge of the plume nearly converges with the plume emanating from the X-749 south contaminated materials storage yard.

\section{X-231A Southeast Oil Degradation Area Contaminant Plume}

The plume associated with the X-231A southeast oil degradation area is composed of TCE, TCA, DCE, and DCA. The highest VOC concentration is TCE at $120 \mathrm{ppb}$. All non-TCE contaminants are contained within the TCE plume. The TCE plume has a semicircular shape extending from the south side of X-231A area (Fig. 7.9).

\section{X-710 Neutralization Pit, X-710 Hot Pit, and X-760 Neutralization Pit Contaminant Plume}

The plume associated with the X-710 neutralization pit, $\mathrm{X}-710$ hot pit, and the $\mathrm{X}-760$ neutralization pit is composed mainly of TCE, with minor amounts of TCA and DCE. The highest level of TCE was $1600 \mathrm{ppb}$, the highest level of DCE was $21 \mathrm{ppb}$, and the highest level of TCA was $5 \mathrm{ppb}$. Contaminants from these two units combine to form a single indistinguishable plume situated almost due south of the X-710 technical services building, under the $X-600 \mathrm{~A}$ coal pile yard, $\mathrm{X}-621$ coal pile runoff treatment facility, and the $\mathrm{X}-749 \mathrm{~A}$ classified material burial grounds. This plume coalesces with the $\mathrm{X}-231 \mathrm{~B}$ southeast oil biodegradation area plume shown in Fig. 7.9. The X-710 neutralization pit and the X-710 hot pit are both located just north of well X231B-36G. VOC contamination was not detected in any Berea sandstone monitoring wells in this area.

\section{X-700 Chemical Cleaning Facility, X-705 Decontamination Building, and X-720 Neutralization Pit Contaminant Plume}

The plume associated with the X-700 chemical cleaning facility, $X-700$ chemical and petroleum storage containment tanks, X-700 TCE/TCA outside storage tank, X-705 decontamination building, and the X-720 neutralization pit is composed primarily of TCE, with a maximum concentration of $19,000 \mathrm{ppb}$. Secondary VOC contaminants are TCA, DCE, chloroform, and methylene chloride. All VOC contaminant plumes are contained within the boundaries of the TCE plume.

\section{Groundwater Treatment Units}

In 1993 approximately 19 million gal of contaminated groundwater were treated at the X-622 south groundwater treatment facility (Fig. 7.9), X-622T treatment trailer (Fig. 7.5), and the X-624 Little Beaver groundwater building (Fig. 7.7). Approximately 107 gal of TCE was removed. All processed water is discharged through an NPDES outfall before exiting the Portsmouth site.

\section{X-622 South Groundwater Treatment Facility}

The groundwater treatment used at the X-622 south groundwater treatment facility is activated carbon filtration of the contaminated groundwater. TCE-contaminated groundwater from the X-231B southwest oil biodegradation plot, the X-749 south contaminated materials storage yard, and the basement sumps in the X-700 chemical cleaning facility and the X-705 decontamination building are processed at this treatment unit. In 1993 the unit processed approximately 9 million gal of groundwater and approximately 9 gal of TCE was removed. The X-700 and X-705 buildings are located above a VOC contaminant groundwater plume. Therefore, the building sumps extract contaminated groundwater. In 1993 the X-622 unit received the sump water for the first five months of the year.

\section{X-622T Groundwater Treatment Trailer}

The groundwater treatment used at the X-622T treatment trailer is activated carbon filtration of contaminated groundwater. From June 1993 to the end of the year, sump water from the X-700 chemical cleaning facility and the X-705 decontamination building was conveyed to the X-622T treatment trailer. Approximately 4.5 million gal was processed, and about 9 gal of TCE was removed. 


\section{X-624 Little Beaver Groundwater Building}

The groundwater treatment used in the X-624 Little Beaver groundwater building is an air stripper with offgas activated carbon filtration plus carbon filtration of the effluent water. TCE-contaminated groundwater from the X-701B holding pond is processed at this treatment unit. In 1993 about 5.5 million gal of groundwater was treated and about $89 \mathrm{gal}$ of TCE removed.

\section{X-701E Neutralizing Building}

The X-701E neutralizing building (Fig. 7.7) is a groundwater treatment using an activated carbon filtration system. Precipitation and groundwater from the X-701B holding pond is pumped to the X-701B neutralizing building for treatment. Treatment is intermittent and depends on the amount of precipitation and the amount of water accumulated in the pond.

\section{Background Sampling}

The USEPA and the OEPA have requested that background metal concentrations be determined from a statistically significant number of samples taken in off-site geologic and hydrogeologic settings similar to those existing on-site. The off-site background sampling will be completed in 1994.

\section{GROUNDWATER MONITORING RESULTS}

The results for groundwater monitoring activities at Portsmouth are discussed briefly under "Groundwater Monitoring at Portsmouth." However, for regularly scheduled compliance monitoring, a more detailed discussion of the results follows.

\section{RCRA Units}

The following Portsmouth RCRA units are included in either an assessment monitoring or detection monitoring program. Historical trends of groundwater contamination are important because changes in groundwater contaminant values help indicate the direction and rate of contaminant migration. Of particular importance are wells that show significant increases or decreases in concentrations or contamination that occurs in previously clean wells. A significant increase can be defined as an annual mean concentration that is at least two standard deviations higher than the previous year's mean.

\section{X-701B Holding Pond}

\section{voc Contamination}

The primary VOC contaminant at X-701B is TCE, which is limited to the Gallia sand. All other contamination is contained within the extent of the TCE plume. None of the X-701B wells had a significant change in TCE concentration (i.e., a 1993 mean concentration more than two standard deviations higher or lower than the 1992 mean concentration). TCE was not detected in groundwater samples from Berea monitoring wells.

\section{Radiological Contamination}

Radiological results were elevated in a number of the Gallia wells located in the X-701B TCE plume (701-06G, X701-08G, X701-14G, and X701-24G). Increases in technetium values were observed in X701-14G and X701-48G. Radiological results from Berea wells at X-701B showed little change from 1992. 


\section{X-749 South Contaminated Materials Storage Yard}

\section{VOC Contamination}

VOC contamination in the Gallia at X-749 is composed primarily of TCE, TCA, DCE, DCA, Freon-113, chloroform, and vinyl chloride. TCE and TCA concentrations continued to increase at wells X749-13G and X749-25G; before 1991 no VOCs had been detected in these wells. At monitoring well X749-07G, DCE and TCA concentrations increased. As part of the X-749 interim remedial measure investigation, a number of wells were installed near the edges of the X-749 plume.

The only VOCs detected in the Berea were DCAs and DCEs (maximum concentration of $13 \mathrm{ppb}$ ) at well X749-50B. Limited cross contamination from the Gallia could have occurred during installation of the well because the well is screened beneath the Gallia VOC plume. However, the annular seal of the well was investigated and found to be intact, so additional cross contamination should not occur. The VOCs, which are still being detected in this well, are thought to be remnants of the original cross contamination.

\section{Radiological Contamination}

In 1993 gross beta activity increased significantly at wells X749-13G and X749-25G. The radionuclide results for the remaining Gallia wells were relatively unchanged from 1992; likewise, results of the Berea radiochemical analyses were similar to the 1992 results.

\section{X-231B Southwest Oil Biodegradation Plot}

\section{VOC Contamination}

The primary VOC contaminant at X-231B is TCE; minor VOC constituents include TCA and DCE. In the Gallia, VOC concentrations increased significantly in wells X231B-02G and X231B-03G and decreased in wells $\mathrm{X} 231 \mathrm{~B}-04 \mathrm{G}$ and X231B-23G. The Berea wells at X-231B are not affected by VOC contamination.

\section{Radiological Contamination}

Results for radiological analyses were elevated in Gallia plume wells X231B-02G, X231B-04G, X231B-06G, and X231B-37G and in Berea well X231B-24B. However, the 1993 values were generally lower than 1992 values. Radiological results from Berea wells at X-231B showed little change from 1992.

\section{X-616 Liquid Effluent Control Facility}

\section{voc Contamination}

VOC contamination was detected in both the Gallia sand and the Berea sandstone at three neighboring wells (X616-09G, X616-16G, and X616-20B). The small area of contamination appears to be centered near the southwest corner of the X-616 surface impoundment. The source of the VOCs may be the nonoperational X-619 sewage treatment unit or an associated adjacent sewage line. The source of the contamination is being investigated. Low levels of VOCs were also detected in an upgradient well screened in the Berea sandstone.

\section{Metals Contamination}

Chromium was the primary contaminant of concern at X-616, versus VOCs for the other RCRA units in assessment monitoring. Both dissolved chromium (filtered) and total chromium (unfiltered) samples are collected at X-616. Both dissolved and total chromium concentrations remain elevated at well X616-05G. However, groundwater chromium concentrations have decreased significantly for the remainder of the wells since X-616 closure activities were completed in 1991. 


\section{Radiological Contamination}

Generally, radiological results for the X-616 wells were below the detection limits.

\section{Surface Water}

Surface water monitoring for Little Beaver Creek, the east drainage ditch, north holding pond, Big Run Creek, the unnamed southwest drainage ditch, and the western drainage ditch is conducted as part of assessment monitoring at X-701B, X-749, X-231B, and X-616. The results discussed in this section pertain only to surface water monitoring conducted in support of the Portsmouth GWPP.

\section{VOC Contamination}

The concentration of VOCs (primarily TCE) in the east drainage ditch and Little Beaver Creek near the $\mathrm{X}-701 \mathrm{~B}$ contaminant plume has decreased since the intercept trench (X-237) for the plume was installed in October 1991. TCE was detected in the first half of 1993, but this was likely caused by pump failures in the intercept trench during this period. TCE was not detected in either the east drainage ditch or Little Beaver Creek after new pumps were installed. At an unnamed southwest drainage ditch sampling site, UNC-SW01, TCE was detected at low concentrations in the third and fourth quarters of 1993. TCE was not detected in Big Run Creek, the north holding pond, or the west drainage ditch in 1993.

\section{Radiological Contamination}

Radiological results for 1993 were generally low for all surface water locations. Technetium was detected in the east drainage ditch during the first half of 1993. However, there were no detectable technetium levels in any of the other surface water locations. None of the surface water monitoring sites showed statistically significant changes for radiological results in 1993. 


\title{
8. Quality Assurance
}

\begin{abstract}
Quality assurance is an integral part of environmental surveillance at Portsmouth Gaseous Diffusion Plant (Portsmouth). Quality controls are part of sampling and monitoring in the field as well as analytical work performed in the Portsmouth laboratory. The Portsmouth laboratory has its own internal quality control program and participates in external quality control programs administered by the U.S. Environmental Protection Agency, the U.S. Department of Energy, and commercial laboratories. Of the 2283 external control measurements made by the Portsmouth laboratory in 1993, the percentage of acceptable results was $98.3 \%$.
\end{abstract}

\section{INTRODUCTION}

Quality assurance (QA), an integral part of the environmental surveillance effort, requires systematic control of the processes involved in sampling the environment and in analyzing the samples. To achieve the desired level of competence, Portsmouth Gaseous Diffusion Plant (Portsmouth) uses the following major types of planned and systematic controls:

- implementation of standard operating procedures for sample collection and analysis,

- surveyor and analyst training and qualification,

- implementation of sample tracking and chain-of-custody procedures to ensure traceability and integrity of samples and data,

- participation in external control programs,

- frequent calibration and routine maintenance of measuring and test equipment,

- maintenance of internal control programs,

- implementation of good measurement techniques and good laboratory practices, and

- frequent assessment of field sampling and measurement activities.

Environmental sampling at Portsmouth is conducted by members of the Environmental Control Department. Sampling plans and procedures are prepared, and appropriate sampling instruments or devices are selected in accordance with practices recommended by the U.S. Environmental Protection Agency (USEPA), the American Society for Testing and Materials, or other authorities. Chain-of-custody documentation is prepared from the point of sampling. The samples remain in the custody of the sampling group until they are transferred to the sample custodian at the laboratory.

An administratively independent QA manager is present at the Portsmouth analytical laboratory. The manager has general oversight responsibility for all phases of laboratory QA. The QA manager is also responsible for the activities of the Laboratory Controls and Standards Group. This group operates the laboratory's central sample-receiving chain-of-custody facility and administers external and internal control programs. The Laboratory Controls and Standards Group also generates internal quality control (QC) samples using materials from the National Institute of Standards and Technology (NIST) or other reliable source materials. The samples are then submitted to the laboratories at an established frequency. Two laboratory statisticians provide support to the laboratory's QA efforts by performing statistical evaluations and administering the control chart program. Good measurement practices used by laboratory personnel include use of matrix spikes, matrix spike duplicates, replicate samples, check samples, and various other internal controls. The extensive internal QC program helps ensure reliability of the analytical data on a day-to-day basis.

Environmental Control Department personnel track and interpret analytical results. Responsibility for interpreting and tracking environmental data is divided because of the large amount of surveillance information generated. Data are reviewed when made available to ascertain compliance with applicable regulations. In some instances, remedial action may be warranted. The data are reviewed periodically for overall interpretation and, 
where relevant, for their interprogram relationships. Documentation of these efforts serves as a resource for future activity.

\section{FIELD SAMPLING AND MONITORING}

Personnel involved in field sampling and monitoring are properly trained. They use approved procedures developed from guidelines and regulations promulgated by the U.S. Department of Energy (DOE) or other regulatory agencies exercising authority over Portsmouth activities. These procedures specify sampling protocol, sampling devices, and containers and preservatives to be used. Chain-of-custody procedures (used with all samples) are documented, and samples are controlled and protected from the point of collection to the generation of analytical results.

\section{Basic Concepts and Practices}

Because data generated from field sampling can be greatly influenced by the methods used to collect and transport the samples, it is imperative that a QA program be in place to ensure that the samples are collected properly and represent the conditions that exist in the environment at the time of sampling. The Portsmouth QA program mandates compliance with written sampling procedures, using clean sampling devices and containers, employing approved sample-preservation techniques, and submitting field blanks and duplicate samples. Chainof-custody procedures are strictly followed to ensure that sample integrity is maintained. Samples are delivered to the laboratory as soon as practicable after collection to ensure sample integrity.

\section{External Gamma Monitoring}

Measurements of external gamma levels on and around the Portsmouth site are collected according to a written procedure based on American National Standards Institute guidelines (ANSI 1975). Thermoluminescent dosimeters are installed, collected, and evaluated by department personnel.

\section{Air Monitoring}

A pretreated filter-paper fluoride collector behind a Teflon particulate filter for collecting radionuclides and fluorides is used as part of the Portsmouth air monitoring network. Materials that will not react with fluorides are used in the sampling train. This ensures that all gaseous fluoride drawn into the sample-train will reach the collector. The flow calibration of the devices that measure total air drawn through the sample trains during the sampling period is checked semiannually to ensure that results accurately reflect airborne concentrations. Written procedures are in place to guide personnel when collecting and analyzing the samples. These procedures provide instruction for monitoring the calibration of the air-metering device.

\section{Surface Water Monitoring}

Liquid effluent streams from Portsmouth are sampled and analyzed in compliance with the National Pollutant Discharge Elimination System (NPDES) discharge permit. Written procedures are used as guides for both sampling and analysis of effluent streams. Flow and $\mathrm{pH}$ are continuously measured and recorded at several discharge points. Calibration of instrumentation is monitored weekly to ensure that reliable data are being collected. Weekly composite samples are collected at two of the NPDES sample sites and one receiving stream site and are measured for radioactive constituents. Once a month, two of these composite samples and an upstream sample from the receiving stream are divided and then shared with the Ohio Department of Health Radiological Health Division for analysis in its laboratory. Comparisons of data from the state laboratory and the Portsmouth laboratory show close correlation. This agreement with the state laboratory is another indicator of the performance quality of the Portsmouth analytical laboratory. 


\section{Groundwater Monitoring}

The Portsmouth Groundwater Monitoring Program requires the use of individually dedicated pumps and delivery lines to purge and pump wells. Dedicated equipment reduces the risk of cross contamination of wells and samples. Written procedures are followed when collecting and analyzing samples. Field blanks and duplicate samples also are submitted to the laboratory to ensure that sampling techniques are not influencing the data being collected.

\section{Biological Monitoring}

Biological monitoring in 1993 included sampling of fish from receiving streams and food crops and grass grown outside the reservation. Randomly selected duplicate samples are submitted to verify the reliability of sampling and analytical procedures. Written procedures are followed when collecting and analyzing these samples.

\section{Soil and Sediment Sampling}

Soil from the area around the Portsmouth reservation and sediment from streams that receive liquid plant discharges are collected semiannually and are analyzed for parameters that would indicate the influence of plant operations on the sampled media. Written procedures are followed for sample collection. Duplicate samples are collected at randomly selected sites to verify the integrity of the sampling techniques.

\section{ANALYTICAL QUALITY ASSURANCE}

The Portsmouth analytical laboratory continues a long tradition of QA and has a well-established QA program. Integral to this program are a highly trained, well-qualified staff; use of approved written procedures and current analytical methodology; availability of excellent equipment and facilities; well-established in-house surveillance, noncompliance reporting, and corrective action programs; and routine use of accepted laboratory practices and measurement techniques. As part of the QA effort, the analytical laboratory maintains comprehensive internal QC programs, participates in a number of external QC programs, and extensively uses statistical interpretation to evaluate its performance.

The laboratory QA program is based on the QA/QC requirements mandated by the Ohio EPA (OEPA), the USEPA, and DOE. Analyses are performed using USEPA-approved methods. Other reliable methods are used when USEPA methods are not available.

During 1993, the Portsmouth laboratory was reaccredited as an American Industrial Hygiene Association Industrial Hygiene Laboratory. In addition, the lab has maintained accreditation from NIST for bulk asbestos fiber analysis under the National Voluntary Laboratory Accreditation Program (NVLAP). The Portsmouth drinking water laboratory is certified by the OEPA for chemical and bacteriological analyses on potable water.

\section{Internal QC}

Internal QC programs at Portsmouth are the basis for ensuring reliable analytical results on a day-to-day and batch-to-batch basis. In accordance with USEPA expectations, the total QC effort in these programs averages from 10 to $20 \%$ of the total laboratory effort. The QC programs also frequently serve as the basis for on-the-job training and qualification of laboratory analysts performing environmental analyses. Internal QC programs, which include both known and blind controls, are routinely administered by the Laboratory Controls and Standards Group, independent of the analytical laboratories. Statistical evaluation of the QC programs is performed by the laboratory statistician.

All analytical activities are supported by the routine use of either standard or reference materials from NIST, the USEPA, other DOE laboratories, or reliable commercial sources. QC is accomplished through the use of such materials for instrument calibrations; preparation of known, blind, and double-blind controls; yield/efficiency determinations; and spike recoveries. Numerous process control charts maintained by the laboratory assist in assessing the adequacy of analytical programs and procedures. If serious deviations are noted, noncompliance 
reports are initiated, investigations are conducted, and corrective actions are implemented. QC data can be retrieved when necessary to support the analytical results.

\section{External QC}

In addition to the internal QC programs, Portsmouth regularly participates in external QC programs. These programs, which are administered by the USEPA, the National Institute of Occupational Safety and Health (NIOSH), DOE, NIST, and commercial laboratories, generate data that serve as a periodic indicator of performance. Results are usually characterized as being acceptable, marginal, or unacceptable. For purposes of the summary that follows, marginal results are included in the acceptable category. Unacceptable results in external control programs are investigated through either the surveillance program or the nonconformance reporting program. Corrective actions are implemented as warranted. A detailed accounting of the Portsmouth . laboratory's performance in external QC programs during CY 1993 is given in Portsmouth Analytical Laboratory CY 93 External Control Program Results (Johnson and Lanning 1994).

\section{Radiological QC}

In 1993 the Portsmouth analytical laboratory participated in two external radiological QC programs: the USEPA Intercomparison Radionuclide Control Program, administered by the USEPA Environmental Monitoring System Laboratory at Las Vegas (EMSL-LV) and the DOE Environmental Measurements Laboratory (EML) Radionuclide Quality Assessment Program. In conjunction with the EMSL-LV, 16 analyses were performed on 6 parameters (alpha and beta activity, total uranium, ${ }^{239} \mathrm{Pu}$, and ${ }^{226} \mathrm{Ra}$ and ${ }^{228} \mathrm{Ra}$ ) in an aqueous matrix. Results in the acceptable range amounted to $75 \%$. Various matrix samples such as water, air filters, soil, tissue, and vegetation are analyzed semiannually for a variety of radioactive isotopes as part of the EML program. In 1993 Portsmouth performed a total of 60 analyses in the two rounds of this program (EML 556 and EML 559). All results were acceptable.

\section{Nonradiological QC}

The Portsmouth laboratory participated in several nonradiological QC programs in 1993, including the Proficiency Environmental Testing Program, the USEPA Discharge Monitoring Report QA Study, the USEPA Water Pollution Performance Evaluation Study (WP), the USEPA Water Supply Study (WS), the NIOSH Proficiency Analytical Testing Program, the NIOSH Environmental Lead Proficiency Analytical Testing Program, and the NIST NVLAP.

The Proficiency Environmental Testing Program is a commercial control program for environmental analysis sponsored by Analytical Products Group, Inc. (APG), of Belpre, Ohio. Samples at two concentration levels representing a wide variety of environmental parameters are distributed monthly to laboratories nationwide. Results are statistically evaluated by the APG and are issued to participating laboratories. The report includes two evaluations as a measure of performance for each analysis: percent recovery of the reference value (which is based on APG's reference value for the analyte) and deviation from the mean result of all reporting laboratories in the program (which provides a performance comparison with all participants). During 1993, 1772 analyses representing 76 analytes were performed. Of the total results, $99 \%$ were deemed acceptable.

The USEPA conducts a national QA program in support of the NPDES program. All holders of major NPDES permits are required to participate. The USEPA furnishes QC samples and evaluates the results. During 1993, 94\% of laboratory results for 16 analytes were deemed acceptable. In addition, results for two parameters (pH and residual chlorine) analyzed by the sample group were also acceptable.

The USEPA WP Study includes a wide variety of organic, inorganic, and miscellaneous test parameters applicable to water pollution analyses. The test materials are prepared and distributed from the EMSL in Cincinnati. Results are evaluated by the participating laboratory's USEPA regional office. In rounds WP030 and WP031, Portsmouth submitted 227 usable results ( 3 results submitted as "less than" values were tagged "unusable" and were not evaluated). Of the usable results, 95\% were acceptable. The USEPA WS Study also includes a variety of inorganic, metal, and organic analytes applicable to analysis of drinking water. The Portsmouth laboratory participated in rounds WS-031 and -032. Analyses of nitrate and turbidity only were required by the state of Ohio to maintain the laboratory's status as a certified drinking water laboratory.

\section{8-4 Quality Assurance}


However, the Portsmouth laboratory voluntarily participated in additional analyses of metals and miscellaneous analytes in round WS-032. Of the 16 results submitted in this program, the only unacceptable result was related to a nonrequired analyte. An acceptable result percentage of $94 \%$ was attained.

Laboratories nationwide participate in the NIOSH Proficiency Analytical Testing Program. Although its primary purpose is to support safety and health programs, this program includes a number of analyses that represent environmental concerns. In each round, four analyses were performed for each of eight parameters (i.e., three metals, silica, asbestos, and three organic solvents). The Portsmouth laboratory achieved $100 \%$ acceptable results for the 128 results submitted during 1993.

The Environmentai Lead Proficiency Analytical Testing Program, established in 1992, is a cooperative effort among NIOSH, the USEPA, and the American Industrial Hygiene Association to improve and evaluate the performance of laboratories involved in the analysis of lead in paint, dust, and soil matrices. During 1993 the Portsmouth laboratory participated in all four rounds (002-005) of this program. Acceptability for the 48 results submitted was $100 \%$.

During 1993 NSST continued the Portsmouth laboratory's accreditation for the analysis of bulk asbestos by polarized light microscopy under the NVLAP Program. Laboratory accreditation is based on the implementation of an extensive QA/QC program, on-site assessment of laboratory operations by the NVLAP technical representative, and satisfactory analysis of all proficiency samples.

\section{Performance Summary}

During 1993, the Portsmouth laboratory performed 2283 external control measurements, 396 more measurements than in 1992. The percentage of acceptable results for 1993 was $98.3 \%$, an increase from $97.9 \%$ in 1992. Because of the constantly increasing emphasis being placed on laboratory QA, it is expected that performance will continue to improve in 1994. 


\title{
9. Unusual Occurrences and Special Studies
}

\begin{abstract}
Unusual occurrences at Portsmouth in 1993 included three spills of ethylene glycol (antifreeze), discovery of trichloroethylene- and petroleum hydrocarbon-contaminated soil during assessments of underground storage tanks, and a pump failure that allowed the escape of trichloroethylenecontaminated groundwater from an interceptor trench. In the summer and fall of 1993, DOE initiated a baseline ecological risk assessment that included several studies regarding plant and wildlife activity.
\end{abstract}

\section{PORTSMOUTH GASEOUS DIFFUSION PLANT SPILL REPORT}

Releases of hazardous substances at Portsmouth are investigated by Portsmouth shift superintendents, Portsmouth Environmental, Safety, and Health personnel, and other staff members. Investigations are conducted to determine environmental impact, provide input for reducing any harmful effects, and monitor potential health effects. Cleanup activities are performed in accordance with Portsmouth standard operating procedures and are monitored by Environmental, Safety, and Health staff. The Portsmouth shift superintendents report all spills or releases to various levels of Portsmouth management and to U.S. Department of Energy (DOE) Oak Ridge Operations officials as appropriate.

In 1993 Portsmouth made three notifications for releases that were thought to exceed Comprehensive Environmental Response, Compensation, and Liability Act (CERCLA) reportable quantities. These incidents included (1) the release of an estimated 15 gal of an ethylene glycol (antifreeze)-water mixture from the airconditioning system at the X-100B building; (2) the release of approximately 5 gal of an ethylene glycol-water mixture into the storm sewer at the X-7745R concrete storage pad; and (3) the release of 1 quart of ethylene glycol from the coolant system of a vehicle in the west parking area of the X-104 building. Because a reportable quantity had not been established for ethylene glycol in 1993, releases were subject to the default reporting limit of $1 \mathrm{lb}$ as required under Section 102 of CERCLA. The following are summaries of the events that caused the releases.

- $\quad X-100 B$ air-conditioning system spill-In the process of repairing a packing lead on a recirculating pump for the air-conditioning system in the X-100B building, the pump packing blew out. As a result, the ethylene glycol-water mixture spilled down the floor drain and subsequently flowed to the south holding pond. No impact on the water quality of the holding pond was observed or expected. The floor drain in the X-100B building was subsequently sealed to prevent any future spills from reaching the environment.

- GX-7725R spill-While cleaning a surplus generator prior to shipment, a contractor ruptured a rubber hose connected to the coolant system, causing a release of approximately 10 gal of ethylene glycol onto the $\mathrm{X}-7725 \mathrm{R}$ concrete storage pad. An estimated 5 gal of liquid entered the storm sewer before the discharge was contained.

- Vehicle spill in X-104 parking area-A vehicle parked in the west parking area of the X-104 building developed a leak in its radiator hose, spilling an estimated 1 quart of ethylene glycol. By the time cleanup was attempted, most of the liquid had evaporated. The vehicle was scheduled for immediate maintenance.

These incidents were reported to the National Response Center, the Ohio Environmental Protection Agency (OEPA), and the Pike County Local Emergency Planning Commission, as well as to DOE and Martin Marietta Energy Systems, Inc. (MMES), management organizations as appropriate.

\section{UNDERGROUND STORAGE TANKS (USTS)}

The UST program is managed in accordance with regulations of DOE, the U.S. Environmental Protection Agency, the OEPA, and the Ohio State Fire Marshal's Bureau of Underground Storage Tank Regulations (BUSTR). Portsmouth registered 26 tanks with BUSTR in 1993, including one waste oil tank at the X-750 facility, which was closed under the Resource Conservation and Recovery Act (RCRA) on May 20, 1993. 
Tanks previously leased to the Defense Logistics Agency and tanks currently leased to the Ohio Army National Guard were included on the Portsmouth annual tank registration.

Eighteen USTs were tightness tested in 1993. Seventeen were certified to be in compliance. One tank, a 550-gal diesel tank for emergency generator power, was not leak-tight. A site check was performed and revealed total petroleum hydrocarbon levels above action levels set forth by BUSTR. In response, a site assessment was performed that seemed to indicate that fuel contamination had not migrated to the surrounding soils or groundwater; however, BUSTR required submittal of a remedial action plan. When approved, the plan will be implemented.

Three tanks managed by MMES have been emptied and are scheduled for closure activities beginning August 30, 1994. These tanks are being closed because they are no longer needed.

One tank was suspected of leaking based on inventory records. The tank was tightness tested August 12, 1993, and no leaks were noted. The problem was determined to be record keeping rather than a leaking tank. The tank was emptied and either must be put back into service or closure proceedings initiated by July 8, 1994 .

Three other tanks, leased by the Ohio Army National Guard, might soon be closed or removed as required under RCRA regulations. The tanks have come into contact with a trichloroethylene (TCE)-contaminated groundwater plume. The tanks are being investigated as part of a RCRA facility investigation. At the request of BUSTR, a second site assessment was performed for three previously closed USTs. The initial findings indicated no further need for remediation; however, BUSTR requested development of a remedial action plan for the stockpiled soils. These soils were treated with microbial agents in 1992 and were disposed of in accordance with the OEPA Petroleum Contaminated Soils Policy, which was superseded in September 1993 by the BUSTR Stockpile Guidance Document.

A site feature scoring system report on previously removed USTs at Portsmouth was prepared and submitted to BUSTR.

During 1993, soil from UST removals was treated with microbial agents that degrade fuel. These soils were disposed of as contaminants were reduced to levels acceptable by regulatory agencies.

\section{NATIONAL POLLUTANT DISCHARGE ELIMINATION SYSTEM (NPDES) TREATMENT BYPASS AT THE X-624 GROUNDWATER TREATMENT FACHLITY}

Historical use of solvents at Portsmouth has resulted in several groundwater contaminant plumes containing TCE. One of these TCE contaminant plumes previously discharged to Little Beaver Creek. To prevent further discharges to the creek, an interceptor trench was constructed and the X-624 carbon treatment facility was built to capture and treat the contaminated groundwater.

Water captured by the interceptor trench was pumped to the treatment facility by two pumps. One of the pumps serving this function failed in late 1992, but it was believed that the remaining pump could adequately pump all of the groundwater captured by the interceptor trench. Subsequent evaluation of the system's pumping design rates, intercept geology, and elevated TCE concentrations in Little Beaver Creek indicated that contaminated groundwater was no longer being effectively captured and treated at the X-624 facility. When the significance of the nonoperable pump was realized, a new pump was installed immediately and additional administrative controls were instituted to ensure proper operation of the system.

The appropriate OEPA personnel were contacted to report and discuss this issue. The event was subsequently classified as an unauthorized discharge under the NPDES program, and a five-day follow-up letter was sent to the OEPA describing the incident and its resolution.

\section{SPECIAL STUDIES}

\section{Ecological Risk Assessment}

In the summer and fall of 1993, DOE initiated the development and preparation of a baseline ecological risk assessment for Portsmouth. Included as part of the risk assessment are several important studies: a wetlands survey, a threatened and endangered plant survey, and a bat survey. To date, Portsmouth has completed the threatened and endangered animal reconnaissance survey and the wetland survey. The wetland survey identified a 
number of areas considered wetland or emergent wetland. These areas will be delineated and mapped in April 1994. The threatened and endangered plant survey began April 4, 1994, and will be completed by October 1994. The bat survey is scheduled to be completed by September 1994. The final reports with regard to these surveys will be submitted to DOE; the OEPA; the U.S. Fish and Wildlife Service; the Department of Natural Resources, Division of Wildlife and Division of Natural Areas and Preserves; and the Ohio Biological Survey.

Survey results also indicate the presence of several state-listed and possibly one federally listed threatened and endangered species within the Portsmouth reservation boundary.

In addition, a wildflower project was started to reduce maintenance costs and risks associated with mowing banks that are slumping or that are too steep to mow safely. An added benefit is that the wildflower areas will be aesthetically pleasing for plant employees and visitors.

DOE is also developing a programmatic agreement with the State Historical Preservation Office. Structures of historic architectural importance, local archaeology, and cultural resources, such as the Mt. Gilead Cemetery, will be the topics of discussion.

All of these studies and projects will mutually benefit DOE, the United States Enrichment Corporation, MMES, and Martin Marietta Utility Services.

\section{Aerial Radiological Survey}

An aerial radiological survey was conducted from August 10-16, 1993, over a 78- $\mathrm{km}^{2}\left(30-\mathrm{mile}^{2}\right)$ area of the Portsmouth plant and the surrounding area near the city of Portsmouth, Ohio. The survey was performed at a nominal altitude of 46 meters $(150 \mathrm{ft}$ ) with a line spacing of 76 meters $(250 \mathrm{ft})$. A contour map of the terrestrial gamma exposure rate extrapolated to 1 meter above ground level was prepared and overlaid on a set of U.S. Geological Survey topographic maps of the area and an aerial photograph of the plant. The terrestrial gamma exposure rates varied from about 7 to 14 microroentgens $(\mathrm{mR})$ per hour at 1 meter above ground. Analysis of the data was performed for human-made sources and for the ${ }^{238} \mathrm{U}$ decay product, ${ }^{234 m} \mathrm{~Pa}$. The presence of ${ }^{234 m} \mathrm{~Pa}$ was observed with elevated readings at six sites within the boundaries of the plant. At a seventh site, only ${ }^{235} \mathrm{U}$ was observed. No other human-made, gamma ray emitting radioactive material was present in a detectable quantity, either on or off the plant property.

Soil sample and pressurized ion chamber measurements were obtained at four locations within the survey boundaries to support the aerial data. The results of the aerial and ground-based measurements were found to agree within $\pm 15 \%$. 


\section{Appendix A: Radiation}

This appendix gives basic facts about radiation. The information is intended to be a basis for understanding the dose associated with releases from the Portsmouth Gaseous Diffusion Plant, not a comprehensive discussion of radiation and its effects on the environment and biological systems. The McGraw-Hill dictionary defines radiation and radioactivity as follows.

radiation-1. The emission and propagation of waves transmitting energy through space or through some medium; for example, the emission and propagation of electromagnetic, sound, or elastic waves.

2. The energy transmitted through space or some medium; when unqualified, usually refers to electromagnetic radiation. Also known as radiant energy. 3. A stream of particles, such as electrons, neutrons, protons, alpha particles, or high-energy photons, or a mixture of these (McGraw-Hill 1989).

radioactivity-A particular type of radiation emitted by a radioactive substance, such as alpha radioactivity (McGraw-Hill 1989).

Radiation occurs naturally. It was not invented; rather, it was discovered. People are constantly exposed to radiation. For example, radon in air, potassium in food and water, and uranium, thorium, and radium in the earth's crust are all sources of radiation. The following discussion describes important aspects of radiation, including atoms and isotopes; types, sources, and pathways of radiation; radiation measurement; and dose information.

\section{ATOMS AND ISOTOPES}

All matter is made up of atoms. An atom is "a unit of matter consisting of a single nucleus surrounded by a number of electrons equal to the number of protons in the nucleus" (ANS 1986). The number of protons in the nucleus determines an element's atomic number, or chemical identity. With the exception of hydrogen, the nuclei of each type of atom also contains at least one neutron. Unlike protons, the number of neutrons may vary among atoms of the same element. The number of neutrons and protons determines the atomic weight. Atoms of the same element with a different number of neutrons are called isotopes. In other words, isotopes have the same chemical properties but different atomic weights. Figure A.1 depicts isotopes of the element hydrogen.

Another example is the element uranium, which has 92 protons; all isotopes of uranium, therefore, have 92 protons. However, each uranium isotope has a different number of neutrons. Uranium-238 (also-denoted ${ }^{238} \mathrm{U}$ ) has 92 protons and 146 neutrons; uranium-239 has 92 protons and 147 neutrons; uranium-240 has 92 protons and 148 neutrons.

Some isotopes are stable, or nonradioactive; some are radioactive. Radioactive isotopes are called radionuclides, or radioisotopes. In an attempt to become stable, radionuclides "throw away," or emit, rays or particles. This emission of rays and particles is known as radioactive decay.

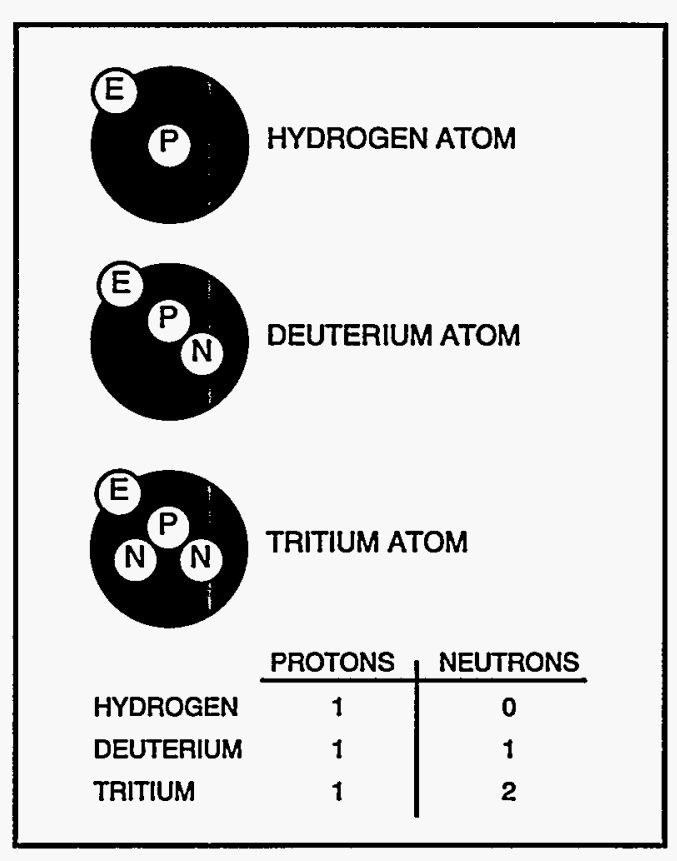

Fig. A.1. Isotopes of the element hydrogen. 


\section{RADIATION}

Radiation, or radiant energy, is energy in the form of waves or particles moving through space. Visible light, heat, radio waves, and alpha particles are examples of radiation. When people feel warmth from the sunlight, they are actually absorbing the radiant energy emitted by the sun.

Electromagnetic radiation is radiation in the form of electromagnetic waves; examples include gamma rays, ultraviolet light, and radio waves. Particulate radiation is radiation in the form of particles; examples include alpha and beta particles. Radiation also is characterized by the way in which it interacts with matter.

\section{lonizing Radiation}

Normally, an atom has an equal number of protons and electrons; however, atoms can lose or gain electrons in a process known as ionization. Some forms of radiation can ionize atoms by "knocking" electrons off atoms. Examples of ionizing radiation include alpha, beta, and gamma radiation. Ionizing radiation is capable of changing the chemical state of matter and subsequently causing biological damage and thus is potentially harmful to human health. Figure A.2 shows the penetrating potential of different types of ionizing radiation.

\section{Nonionizing Radiation}

Nonionizing radiation bounces off of or passes through matter without displacing electrons. Examples include visible light and radio waves. Currently, it is unclear whether nonionizing radiation is harmful to human health. In the discussion that follows, the term radiation is used to describe ionizing radiation.

\section{SOURCES OF RADIATION}

Radiation is everywhere. Most occurs naturally, whereas a small percentage is human made. Naturally occurring radiation is known as background radiation.

\section{Background Radiation}

Many materials are naturally radioactive. In fact, this naturally occurring radiation is the major source of radiation in the environment. Though people have little control over the amount of background radiation to which they are exposed, this exposure must be put into perspective. Background radiation remains relatively constant over time; background radiation present in the environment today is much the same as it was hundreds of years ago.

Sources of background radiation include uranium in the earth, radon in the air, and potassium in food. Background radiation is categorized as cosmic, terrestrial, or internal, depending on its origin.

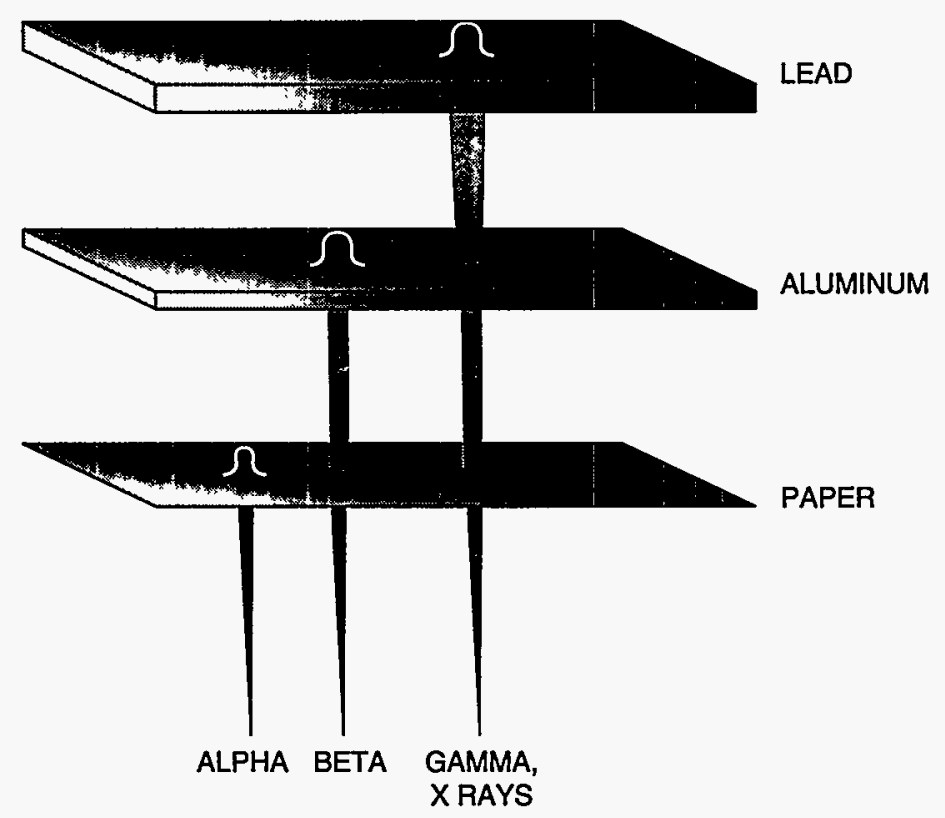

Fig. A.2. Penetrating power of radiation. Some types of radiation can be easily shielded against. For example, a sheet of paper is sufficient to stop an alpha particle. Gamma rays can pass through paper but can be stopped by the appropriate amount of lead. Radiation's ability to penetrate is an important consideration in protecting human health. Adequate shielding decreases the power of radiation by absorbing part or all of it. 


\section{Cosmic Radiation}

Energetically charged particles from outer space continuously hit the earth's atmosphere. These particles and the secondary particles and photons they create are called cosmic radiation. Because the atmosphere provides some shielding against cosmic radiation, the intensity of this radiation increases with altitude above sea level. In other words, a person in Denver, Colorado, is exposed to more cosmic radiation than a person in Death Valley, California.

\section{Terrestrial Radiation}

Terrestrial radiation refers to radiation emitted from radioactive materials in the earth's rocks, soils, and minerals. Radon $(\mathrm{Rn})$; radon progeny (the relatively short-lived decay products of ${ }^{235} \mathrm{Ra}$ ); potassium $\left({ }^{40} \mathrm{~K}\right)$; isotopes of thorium (Th); and isotopes of uranium $(U)$ are the elements responsible for most terrestrial radiation.

\section{Internal Radiation}

Radioactive material in the environment enters the body with the air people breathe and the food they eat; it also can enter through an open wound. Natural radionuclides in the body include isotopes of uranium, thorium, radium, radon, polonium, bismuth, and lead in the ${ }^{238} \mathrm{U}$ and ${ }^{232} \mathrm{Th}$ decay series. In addition, the body contains isotopes of potassium $\left({ }^{40} \mathrm{~K}\right)$, rubidium $\left({ }^{87} \mathrm{Rb}\right)$, and carbon $\left({ }^{14} \mathrm{C}\right)$.

\section{Human-Made Radiation}

In addition to background radiation, there are human-made sources of radiation to which most people are exposed. Examples include consumer products, medical sources, and fallout from atmospheric atomic bomb tests. (Atmospheric testing of atomic weapons has been suspended.) Also, about one-half of $1 \%$ of the U.S. population performs work in which radiation in some form is present.

\section{Consumer Products}

Some consumer products are sources of radiation. In some of these products, such as smoke detectors and airport X-ray baggage inspection systems, radiation is essential to the performance of the device. In other products, such as televisions and tobacco products, the radiation occurs incidentally to the product function.

\section{Medical Sources}

Radiation is an important tool of diagnostic medicine and treatment, and, in this use, is the main source of exposure to human-made radiation. Exposure is deliberate and directly beneficial to the patients exposed. Generally, medical exposures from diagnostic or therapeutic $\mathrm{X}$ rays result from beams directed to specific areas of the body. Thus, all body organs generally are not irradiated uniformly. Radiation and radioactive materials are also used in a wide variety of pharmaceuticals and in the preparation of medical instruments, including the sterilization of heat-sensitive products such as plastic heart valves. Nuclear medicine examinations and treatment involve the internal administration of radioactive compounds, or radiopharmaceuticals, by injection, inhalation, consumption, or insertion. Even then, radionuclides are not distributed uniformly throughout the body.

\section{Other Sources}

Other sources of radiation include fallout from atmospheric atomic bomb tests; emissions of radioactive materials from nuclear facilities such as uranium mines, fuel processing plants, and nuclear power plants; emissions from mineral extraction facilities; and transportation of radioactive materials. 


\section{PATHWAYS OF RADIATION}

Radiation and radioactive material in the environment can reach people through many routes. Potential routes for radiation are referred to as pathways. For example, radioactive material in the air could fall on a pasture. The grass could then be eaten by cows, and the radioactive material on the grass would show up in the cow's milk. People drinking the milk would thus be exposed to this radiation. Or, people could simply inhale the radioactive material in the air. The same events could occur with radioactive material in water. Fish living in the water would be exposed; people eating the fish would then be exposed to the radiation in the fish. Or, people swimming in the water would be exposed (see Fig. A.3).

\section{MEASURING RADIATION}

To determine the possible effects of radiation on the environment and the health of people, the radiation must be measured. More precisely, its potential to cause damage must be ascertained.

\section{Activity}

When measuring the amount of radiation in the environment, what is actually being measured is the rate of radioactive decay, or activity. The rate of decay varies

ORNL-DWG 94M-5235

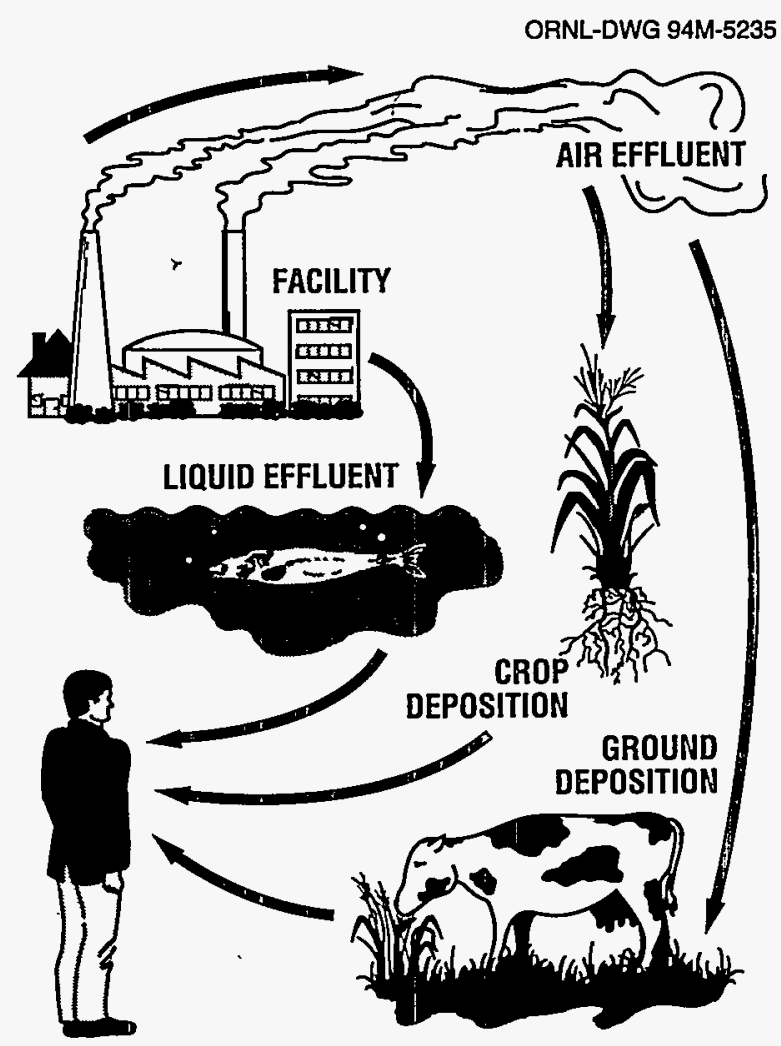

Fig. A.3. Possible radiation pathways. widely among the various radioisotopes. For that reason, $1 \mathrm{~g}$ of a radioactive substance may contain the same amount of activity as several tons of another material. This activity is expressed in a unit of measure known as a curie ( $\mathrm{Ci})$. More specifically, $1 \mathrm{Ci}=3.7 \mathrm{E}+10(37,000,000,000)$ atom disintegrations per second (dps). In the international system of units, $1 \mathrm{dps}=1$ becquerel (Bq).

\section{Absorbed Dose}

The total amount of energy absorbed per unit mass as a result of exposure to radiation is expressed in a unit of measure known as a rad. In the international system of units, $100 \mathrm{rad}$ equals 1 gray (Gy). However, in terms of human health, it is the effect of the absorbed energy that is important, not the actual amount.

\section{Dose Equivalent}

The measure of potential biological damage caused by exposure to and subsequent absorption of radiation is expressed in a unit of measure known as a rem. One rem of any type of radiation has the same total damaging effect. Because a rem represents a fairly large dose, dose is expressed as a millirem (mrem), or 1/1000 of a rem. In the international system of units, 100 rem equals 1 sievert (Sv); 100 mrem equals 1 millisievert (mSv).

\section{DOSE}

Many terms are used to report dose. Several factors are taken into account, including the amount of radiation absorbed, the organ absorbing the radiation, and the effect of the radiation over a 50-year period. The term "dose," in this report, includes the committed effective dose equivalent (EDE) and the effective dose equivalent attributable to penetrating radiation from sources external to the body. 


\begin{abstract}
Dose Terminology
absorbed dose

quantity of radiation energy absorbed by an organ divided by an organ's mass

dose equivalent

absorbed dose to an organ multiplied by a quality factor

effective dose

equivalent

single weighted sum of combined dose equivalents received by all organs

committed dose equivalent

effective dose equivalent to an organ over a 50-year period following intake

committed effective

total effective dose equivalent to all organs in the human body over

dose equivalent

a 50-year period following intake

collective effective

sum of effective dose equivalents of all members of a given

dose equivalent

population

quality factor

modifying factor used to adjust for the effect of the type of radiation, for example, alpha particles or gamma rays, on tissue

weighting factor

tissue-specific modifying factor representing the fraction of the total health risk from uniform, whole-body exposure
\end{abstract}

Determining dose is an involved process using complex mathematical equations based on several factors, including the type of radiation, the rate of exposure, weather conditions, and typical diet. Basically, radiant energy is generated from radioactive decay, or activity. People absorb some of the energy to which they are exposed. This absorbed energy is calculated as part of an individual's dose. Whether radiation is natural or human made, it has the same effect on people.

\title{
Comparison of Dose Levels
}

A scale of dose levels is presented in Table A.1. Included is an example of the type of exposure that may cause such a dose or the special significance of such a dose. This information is intended to help the reader become familiar with the type of doses individuals may receive.

\section{Dose from Cosmic Radiation}

The average annual dose received by residents of the United States from cosmic radiation is about 27 mrem $(0.27 \mathrm{mSv}$ ) (NCRP 1987). The average annual dose from cosmic radiation received by residents in the Portsmouth area is about 50 mrem $(0.33 \mathrm{mSv})$.

\section{Dose from Terrestrial Radiation}

The average annual dose received from terrestrial gamma radiation is about $28 \mathrm{mrem}(0.28 \mathrm{mSv})$ in the United States. This dose varies geographically across the country (NCRP 1987); typical reported values are $16 \mathrm{mrem}(0.16 \mathrm{mSv})$ at the Atlantic and Gulf coastal plains and about $63 \mathrm{mrem}(0.63 \mathrm{mSv})$ at the eastern slopes of the Rocky Mountains. 


\section{Dose from Internal Radiation}

Short-lived decay products of radon are the major contributors to the annual dose equivalent for internal radionuclides (mostly ${ }^{222} \mathrm{Rn}$ ). They contribute an average dose of about $200 \mathrm{mrem}(2.00 \mathrm{mSv})$ per year. This dose estimate is based on an average radon concentration of about $1 \mathrm{pCi} / \mathrm{L}(0.037 \mathrm{~Bq} / \mathrm{L})$ (NCRP 1987).

The average dose from other internal radionuclides is about 39 mrem ( $0.39 \mathrm{mSv})$ per year, most of which can be attributed to the naturally occurring isotope of potassium, ${ }^{40} \mathrm{~K}$. The concentration of radioactive potassium in human tissues is similar in all parts of the world (NCRP 1987).

\section{Dose from Consumer Products}

The U.S. average annual dose received by an individual from consumer products is about $10 \mathrm{mrem}$ (0.10 mSv) (NCRP 1987).

\section{Dose from Medical Sources}

Nuclear medicine examinations, which involve the internal administration of radiopharmaceuticals, generally account for the largest portion of the dose received from human-made sources. However, the radionuclides used in specific tests are not distributed uniformly throughout the body. In these cases, comparisons are made using the concept of EDE, which relates exposure of organs or body parts to one effective whole-body dose. The average annual EDE from medical examinations is $53 \mathrm{mrem}(0.53 \mathrm{mSv})$, including $39 \mathrm{mrem}(0.39 \mathrm{mSv})$ for diagnostic $X$ rays and $14 \mathrm{mrem}(0.14 \mathrm{mSv})$ for nuclear medicine procedures (NCRP 1989). The actual doses received by individuals who complete such medical exams are much higher than these values, but not everyone receives such exams each year (NCRP 1989).

\section{Dose from Other Sources}

Small doses received by individuals occur as a result of radioactive fallout from atmospheric atomic bomb tests, emissions of radioactive materials from nuclear facilities, emissions from certain mineral extraction facilities, and transportation of radioactive materials. The combination of these sources contributes less than $1 \mathrm{mrem}(0.01 \mathrm{mSv})$ per year to the average dose to an individual (NCRP 1987).

A comprehensive U.S. Environmental Protection Agency (USEPA) report of 1984 projected the average occupational dose to monitored radiation workers in medicine, industry, the nuclear fuel cycle, government, and miscellaneous industries to be $105 \mathrm{mrem}(1.05 \mathrm{mSv})$ per year for 1985 , down slightly from $110 \mathrm{mrem}$ $(1.10 \mathrm{mSv}$ ) per year in 1980 (Kumazawa et al. 1984).

\section{How are Workers and the Public Being} Protected?

Portsmouth is equipped with alarms that automatically warn employees of significant increases in radiation levels. Dosimeters, or radiation-sensitive personnel badges, are worn by all employees and visitors entering any plant-site limited area. Protective clothing and
respiratory equipment are worn during work assignments involving an increased risk of contacting radioactive materials, and workers are monitored for contamination when leaving restricted areas. Employees undergo extensive training so that they understand operating procedures and all emergency and safety requirements.

A public warning system has also been in place at the plant since 1988. In the unlikely event of a significant environmental release residents within a 2 -mile radius of the plant. Local emergency preparedness agencies and area media would also be notified simultaneously. with the potential to go off-site, the public 
Table A.1. Comparison and description of various dose levels

\begin{tabular}{|c|c|}
\hline Dose level & Description \\
\hline $1 \mathrm{mrem}(0.01 \mathrm{mSv})$ & Approximate daily dose from natural background radiation, including radon \\
\hline $2.5 \mathrm{mrem}(0.025 \mathrm{mSv})$ & $\begin{array}{l}\text { Cosmic dose to a person on a one-way airplane flight from New York to Los } \\
\text { Angeles }\end{array}$ \\
\hline $10 \mathrm{mrem}(0.10 \mathrm{mSv})$ & $\begin{array}{l}\text { Annual exposure limit, set by the USEPA, for exposures from airborne } \\
\text { emissions from operations of nuclear fuel cycle facilities, including power } \\
\text { plants and uranium mines and mills }\end{array}$ \\
\hline $46 \mathrm{mrem}(0.46 \mathrm{mSv})$ & $\begin{array}{l}\text { Estimate of the largest dose any off-site person could have received from the } \\
\text { March 28,1979, Three Mile Island nuclear power plant accident }\end{array}$ \\
\hline $50 \mathrm{mrem}(0.50 \mathrm{mSv})$ & $\begin{array}{l}\text { Average yearly dose from cosmic radiation received by people in the } \\
\text { Portsmouth area }\end{array}$ \\
\hline $66 \mathrm{mrem}(0.66 \mathrm{mSv})$ & Average yearly dose to people in the United States from human-made sources \\
\hline $100 \mathrm{mrem}(1.00 \mathrm{mSv})$ & $\begin{array}{l}\text { Annual limit of dose from all U.S. Department of Energy facilities to a } \\
\text { member of the public who is not a radiation worker }\end{array}$ \\
\hline 110 mrem $(1.10 \mathrm{mSv})$ & $\begin{array}{l}\text { Average occupational dose received by U.S. commercial radiation workers in } \\
1980\end{array}$ \\
\hline $244 \mathrm{mrem}(2.44 \mathrm{mSv})$ & Average dose from an upper gastrointestinal diagnostic $\mathrm{X}$-ray series \\
\hline $300 \mathrm{mrem}(3.00 \mathrm{mSv})$ & $\begin{array}{l}\text { Average yearly dose to people in the United States from all sources of natural } \\
\text { background radiation }\end{array}$ \\
\hline $1-5$ rem $(0.01-0.05 \mathrm{~Sv})$ & $\begin{array}{l}\text { USEPA Protective Action Guidelines state that public officials should take } \\
\text { emergency action when the dose to a member of the public from a nuclear } \\
\text { accident will likely reach this range }\end{array}$ \\
\hline $5 \mathrm{rem}(0.05 \mathrm{~Sv})$ & $\begin{array}{l}\text { Annual limit for occupational exposure of radiation workers set by the U.S. } \\
\text { Nuclear Regulatory Commission and the U.S. Department of Energy }\end{array}$ \\
\hline $10 \mathrm{rem}(0.10 \mathrm{~Sv})$ & $\begin{array}{l}\text { The BEIR V report estimated that an acute dose at this level would result in a } \\
\text { lifetime excess risk of death from cancer, caused by the radiation, of } 0.8 \% \\
\text { (BEIR 1990) }\end{array}$ \\
\hline $25 \mathrm{rem}(0.25 \mathrm{~Sv})$ & $\begin{array}{l}\text { USEPA guideline for voluntary maximum dose to emergency workers for } \\
\text { non-lifesaving work during an emergency }\end{array}$ \\
\hline $75 \mathrm{rem}(0.75 \mathrm{~Sv})$ & $\begin{array}{l}\text { USEPA guideline for maximum dose to emergency workers volunteering for } \\
\text { lifesaving work }\end{array}$ \\
\hline $50-600 \mathrm{rem}(0.50-6.00 \mathrm{~Sv})$ & $\begin{array}{l}\text { Doses in this range received over a short period of time will produce radiation } \\
\text { sickness in varying degrees. At the lower end of this range, people are } \\
\text { expected to recover completely, given proper medical attention. At the top of } \\
\text { this range, most people would die within } 60 \text { days }\end{array}$ \\
\hline
\end{tabular}

Adapted from Savannah River Site Environmental Report for 1993, Summary Pamphlet, WSRC-TR-94-076, Westinghouse Savannah River Company, 1994. 


\section{Appendix B: Environmental Permits}

Table B.1. Portsmouth environmental permits as of March 30, 1994

\begin{tabular}{|c|c|c|}
\hline $\begin{array}{l}\text { Permitted } \\
\text { unit }\end{array}$ & $\begin{array}{l}\text { Issue } \\
\text { date }\end{array}$ & $\begin{array}{l}\text { Expiration } \\
\text { date }\end{array}$ \\
\hline \multicolumn{3}{|c|}{ Air permits } \\
\hline $\begin{array}{l}\text { X-700 solvent-contaminated water } \\
\text { treatment system }\end{array}$ & July 3, 1992 & July 2, 1995 \\
\hline $\mathrm{X}-735$ refuse/asbestos handling & February 9, 1993 & February 8, 1996 \\
\hline $\mathrm{X}-735$ sanitary landfill license & December 31, 1993 & December 31, 1994 \\
\hline Open burning permit & December 31, 1993 & December 31, 1994 \\
\hline $\mathrm{X}-600$ steam plant boiler 1 (south) & March 18, 1994 & March 17, 1997 \\
\hline $\mathrm{X}-600$ steam plant boiler 2 (middle) & March 18, 1994 & March 17, 1997 \\
\hline$X-600$ steam plant boiler 3 (north) & March 18, 1994 & March 17, 1997 \\
\hline $\mathrm{X}-735$ roads/parking area landfill & February 9, 1993 & February 8, 1996 \\
\hline $\mathrm{X}-720$ compressor shop vapor degreaser & December 8, 1992 & December 8, 1995 \\
\hline $\mathrm{X}-720$ motor shop vapor degreaser ${ }^{b}$ & & December 8, 1992 \\
\hline X-720 motor shop burn-off oven & May 18,1990 & May 18, 1993 \\
\hline $\mathrm{X}-700$ vapor degreaser & October 23, 1992 & October 22, 1995 \\
\hline \multicolumn{2}{|c|}{ Wastewater permits } & - \\
\hline $\begin{array}{l}\text { National Pollutant Discharge } \\
\text { Elimination System }\end{array}$ & September 23, 1991 & July 29, 1994 \\
\hline \multicolumn{3}{|c|}{ Hazardous waste permits } \\
\hline $\begin{array}{l}\text { Applications for Resource Conservation } \\
\text { submitted May 13, 1992, and June 5, } 19\end{array}$ & overy Act Part A a & B permits were \\
\hline
\end{tabular}

${ }^{a}$ Applications for 235 air emission source permits are pending with the Ohio Environmental Protection Agency.

${ }^{b}$ This source is not in use, and a project has been initiated to remove it. Permit will not be renewed. 


\section{Appendix C: Chemical Release Data}

Table C.1. Portsmouth Gaseous Diffusion Plant chemical releases for 1993

\begin{tabular}{|c|c|c|c|c|c|}
\hline Chemical & & $\begin{array}{l}\text { Type of } \\
\text { release }\end{array}$ & $\begin{array}{l}\text { Release quantity } \\
\text { [lb (kg)] }\end{array}$ & $\begin{array}{l}\text { Major release } \\
\text { sources }\end{array}$ & $\begin{array}{l}\text { Basis of } \\
\text { estimate }\end{array}$ \\
\hline \multicolumn{6}{|c|}{$S A R A 313^{a}$} \\
\hline Chlorine & Air: & stack & $76(35)$ & Production vents & Other \\
\hline CFC -114 & Air: & fugitive & $344,000(156,000)$ & Air-conditioning systems & Usage records \\
\hline Methanol & Air: & $\begin{array}{l}\text { fugitive } \\
\text { stack }\end{array}$ & $\begin{array}{l}2100(940) \\
270(120)\end{array}$ & $\begin{array}{l}\text { Biodenitrification facility } \\
\text { Biodenitrification facility }\end{array}$ & $\begin{array}{l}\text { Other } \\
\text { Emission factors }\end{array}$ \\
\hline Nitric acid & Air: & stack & $860(390)$ & $\begin{array}{l}\text { Miscellaneous equipment } \\
\text { cleaning }\end{array}$ & Other \\
\hline Sulfuric acid & Water: & Scioto River & $0(0)$ & Cooling systems & Monitoring data \\
\hline Zinc & Water: & $\begin{array}{l}\text { Scioto River } \\
\text { Little Beaver Creek } \\
\text { Big Run Creek } \\
\text { West drainage ditch } \\
\text { Southwest drainage } \\
\text { ditch }\end{array}$ & $\begin{array}{c}220(100) \\
200(93) \\
77(35) \\
29(13) \\
3(1)\end{array}$ & $\begin{array}{l}\text { Water treatment } \\
\text { Water treatment } \\
\text { Water treatment } \\
\text { Water treatment } \\
\text { Water treatment }\end{array}$ & $\begin{array}{l}\text { Monitoring data } \\
\text { Monitoring data } \\
\text { Monitoring data } \\
\text { Monitoring data } \\
\text { Monitoring data }\end{array}$ \\
\hline \multicolumn{6}{|c|}{ Other large-inventory chemicals } \\
\hline CFC-12 & Air: & fugitive & $2300(1000)$ & Air-conditioning systems & Other \\
\hline CFC-22 & Air: & fugitive & $1100(480)$ & Air-conditioning systems & Other \\
\hline CFC-113 & Air: & fugitive & $2600(1200)$ & $\begin{array}{l}\text { Miscellaneous equipment } \\
\text { cleaning }\end{array}$ & Othere \\
\hline \multirow[t]{2}{*}{ Ethylene glycol } & Air: & fugitive & $330(150)$ & Air-conditioning systems & Other \\
\hline & Water: & $\begin{array}{l}\text { Big Run Creek } \\
\text { West drainage ditch }\end{array}$ & $\begin{array}{c}80(36) \\
130(59)\end{array}$ & $\begin{array}{l}\text { Air-conditioning system } \\
\text { spill } \\
\text { Emergency generator } \\
\text { spill }\end{array}$ & $\begin{array}{l}\text { Other } \\
\text { Othere }\end{array}$ \\
\hline Hydrogen fluoride & Air: & stack & $6900(3200)$ & Production vents & Monitoring data \\
\hline \multirow[t]{2}{*}{ 1,1,1-Trichloroethane } & Air: & fugitive & $590(270)$ & $\begin{array}{l}\text { Miscellaneous equipment } \\
\text { cleaning }\end{array}$ & Other \\
\hline & & stack & $1200(560)$ & $\begin{array}{l}\text { Miscellaneous equipment } \\
\text { cleaning }\end{array}$ & Othere \\
\hline \multicolumn{6}{|c|}{ Steam Plant } \\
\hline Sulfur dioxide & Air: & stack & $5,900,000(2,700,000)$ & Steam plant emissions & Other \\
\hline Nitrogen oxides & Air: & stack & $780,000(350,000)$ & Steam plant emissions & Emission factors \\
\hline Carbon monoxide & Air: & stack & $280,000(130,000)$ & Steam plant emissions & Emission factors ${ }^{e}$ \\
\hline Particulates & Air: & stack & $58,000(26,000)$ & Steam plant emissions & Other \\
\hline
\end{tabular}

"Superfund Amendments and Reauthorization Act of 1986, Title III, Section 313.

${ }^{b}$ Chlorofluorocarbon.

'Based on best engineering judgement.

Based on coal analysis.

Based on emission factors from U.S. Environmental Protection Agency guidance document AP-42, Compilation of Air Pollution Emission Factors.

$f_{B a s e d}$ on coal analysis and demonstrated performance of electrostatic precipitators. 


\section{Appendix D: Radionuclide and Chemical Nomenclature}

Nomenclature and half-life for radionuclides

\begin{tabular}{lll||lll}
\hline Radionuclide & Symbol & Half-life & Radionuclide & Symbol & Half-life \\
\hline Bismuth-210 & ${ }^{210} \mathrm{Bi}$ & 5.01 days & Radium-226 & ${ }^{226} \mathrm{Ra}$ & 1,602 years \\
Bismuth-214 & ${ }^{214} \mathrm{Bi}$ & 19.7 minutes & Radon-222 & ${ }^{22} \mathrm{Rn}$ & 3.821 days \\
Lead-206 & ${ }^{206} \mathrm{~Pb}$ & Stable & Technetium-99 & ${ }^{99} \mathrm{Tc}$ & 212,000 years \\
Lead-210 & ${ }^{210} \mathrm{~Pb}$ & 21 years & Thorium-230 & ${ }^{230} \mathrm{Th}$ & 80,000 years \\
Lead-214 & ${ }^{214} \mathrm{~Pb}$ & 26.8 minutes & Thorium-231 & ${ }^{231} \mathrm{Th}$ & 25.5 hours \\
Polonium-210 & ${ }^{210} \mathrm{Po}$ & 138.9 days & Thorium-234 & ${ }^{234} \mathrm{Th}$ & 24.1 days \\
Polonium-214 & ${ }^{214} \mathrm{Po}$ & 164 microseconds & Uranium-234 & ${ }^{234} \mathrm{U}$ & 247,000 years \\
Polonium-218 & ${ }^{218} \mathrm{Po}$ & 3.05 minutes & Uranium-235 & ${ }^{235} \mathrm{U}$ & $710,000,000$ years \\
Potassium-40 & ${ }^{40} \mathrm{~K}$ & $1,260,000,000$ years & Uranium-236 & ${ }^{236} \mathrm{U}$ & $23,900,000$ years \\
Protactinium-234m & ${ }^{234 m} \mathrm{~Pa}$ & 1.17 minutes & Uranium-238 & ${ }^{238} \mathrm{U}$ & $4,510,000,000$ years \\
\hline
\end{tabular}

Nomenclature for elements and chemical constituents

\begin{tabular}{ll||ll}
\hline Constituent & $\mathrm{Symbol}$ & Constituent & $\mathrm{Symbol}$ \\
\hline Aluminum & $\mathrm{Al}$ & Manganese & $\mathrm{Mn}$ \\
Ammonia & $\mathrm{NH}_{3}$ & Mercury & $\mathrm{Hg}$ \\
Antimony & $\mathrm{Sb}$ & Nickel & $\mathrm{Ni}$ \\
Arsenic & $\mathrm{As}$ & Nitrogen & $\mathrm{N}$ \\
Barium & $\mathrm{Ba}$ & Nitrate & $\mathrm{NO}_{3}$ \\
Beryllium & $\mathrm{Be}$ & Nitrite & $\mathrm{NO}_{2}$ \\
Cadmium & $\mathrm{Cd}$ & Oxygen & $\mathrm{O}$ \\
Calcium & $\mathrm{Ca}$ & Ozone & $\mathrm{O}_{3}$ \\
Calcium carbonate & $\mathrm{CaCO}$ & Phosphorus & $\mathrm{P}$ \\
Carbon & $\mathrm{C}$ & Phosphate & $\mathrm{PO}_{4}$ \\
Chlorine & $\mathrm{Cl}$ & Potassium & $\mathrm{K}$ \\
Chromium & $\mathrm{Cr}$ & Radium & $\mathrm{Ra}$ \\
Chromium, hexavalent & $\mathrm{Cr}$ & Radon & $\mathrm{Rn}$ \\
Cobalt & $\mathrm{Co}$ & Selenium & $\mathrm{Se}$ \\
Copper & $\mathrm{Cu}$ & Silver & $\mathrm{Ag}$ \\
Fluorine & $\mathrm{F}$ & Sodium & $\mathrm{Na}$ \\
Hydrogen fluoride & $\mathrm{HF}$ & Sulfate & $\mathrm{SO}_{4}$ \\
Iron & $\mathrm{Fe}$ & Sulfur dioxide & $\mathrm{SO}_{2}$ \\
Lead & $\mathrm{Pb}$ & Thorium & $\mathrm{Th}$ \\
Lithium & $\mathrm{Li}$ & Uranium & $\mathrm{U}$ \\
Magnesium & $\mathrm{Mg}$ & Zinc & $\mathrm{Zn}$ \\
\hline
\end{tabular}




\section{Appendix E: Errata for the Portsmouth Gaseous Diffusion Plant Environmental Report for 1992}

Part 1, page 3-8, Table 3.2.

\begin{tabular}{lll}
\multicolumn{3}{c}{ Table 3.2. 1992 PORTS radionuclide air emissions } \\
\hline \multicolumn{1}{c}{ Radionuclide } & kg/year & Ci/year \\
\hline${ }^{234} \mathrm{U}$ & 0.022 & 0.013 \\
${ }^{235} \mathrm{U}$ & 1.77 & 0.0038 \\
${ }^{236} \mathrm{U}$ & 0.00018 & 0.000012 \\
${ }^{238} \mathrm{U}$ & 6.60 & 0.0022 \\
${ }^{T} \mathrm{otal}$ uranium & 8.39 & 0.14 \\
${ }^{99} \mathrm{Tc}$ & 0.072 & 1.23 \\
Uranium daughters & $1.0 \times 10^{-10 a}$ & 0.0082 \\
\hline
\end{tabular}

${ }^{a} 0.0000000001$.

The first line of this table contains a typographical error in the activity emissions for ${ }^{234} \mathrm{U}$; it should read

\begin{tabular}{ccc} 
Radionuclide & $\mathrm{kg} /$ year & $\mathrm{Ci} /$ year \\
\hline${ }^{234} \mathrm{U}$ & 0.022 & 0.13
\end{tabular}

The remainder of the table (including total uranium emissions) is correct. 


\section{References}

American Nuclear Society (ANS). 1986. Glossary of Terms in Nuclear Science and Technology, American Nuclear Society.

American National Standards Institute (ANSI). 1975. Performance Testing and Procedural Specifications for Thermoluminescent Dosimetry (Environmental Applications), New York, N.Y.

Baker, D. A., and J. K. Soldat. 1993. "Methods for Estimating Doses to Organisms from Radioactive Materials Released into the Aquatic Environment," PNL-8150, Pacific Northwest Laboratories, Richland, Wash.

Beres, D. A. 1990. The Clean Air Act Assessment Package-1988 (CAP-88): A Dose and Risk Assessment Methodology for Radionuclide Emissions to Air, SC\&A, Inc., McLean, Va.

BEIR. 1990. Health Effects of Exposure to Low Levels of Ionizing Radiation, Committee on the Biological Effects of Ionizing Radiations (BEIR V), National Research Council, National Academy of Sciences, National Academy Press, Washington, D.C.

Geraghty and Miller. 1989. Groundwater Quality Assessment of Four RCRA Units. Dublin, Ohio.

International Commission on Radiological Protection (ICRP). 1977. Annals of the ICRP 1, ICRP Publication 26, Pergamon, Oxford, N.Y. 1978. Publication 30, Pergamon, Oxford, N.Y.

Johnson, R., and B. Lanning. June 1994. Portsmouth Analytical Laboratory CY 93 External Control Program Results, POEF-TO-30.

Kumazawa S., et al. 1984. Occupational Exposure to Ionizing Radiation in the United States: A Comprehensive Review for the Year 1980 and a Summary of Trends for the Years 1960-1985, EPA/520/1-8-005, U.S. Government Printing Office, Washington, D.C.

Martin Marietta Energy Systems (MMES). March 31, 1994. Environmental Monitoring Plan for the Portsmouth Gaseous Diffusion Plant, POEF-EW-11.

McGraw-Hill. 1989. McGraw-Hill Dictionary of Scientific and Technical Terms, 4th ed., McGraw-Hill, Inc., New York.

National Council on Radiation Protection (NCRP). 1983. Iodine-129: Evaluation of Releases from Nuclear Power Generation, NCRP Report No. 75, National Council on Radiation Protection and Measurements, Bethesda Md.

1987. Ionizing Radiation Exposure of the Population of the United States, NCRP Report No. 93, National Council on Radiation Protection and Measurements, Washington, D.C. 1989. Exposure of the U.S. Population from Diagnostic Medical Radiation, NCRP Report No. 100, National Council on Radiation Protection and Measurements, Bethesda, Md.

U.S. Environmental Protection Agency (USEPA). September 1989a. RCRA Groundwater Monitoring Technical Enforcement Guidance Document, OSWER-9950.1, USEPA.

1989b. Risk Assessment Guidance for Superfund: Human Health Evaluation Manual, Part A Interim Final), Washington, D.C. 1991. Integrated Risk Information System (IRIS) (data base), Washington, D.C.

U.S. Department of Commerce, Bureau of the Census. April 1991. 1990 Census of Population and Housing Public Law 94-171 Data, Washington, D.C. 


\section{Glossary}

absorption-The process by which the number and energy of particles or photons entering a body of matter is reduced by interaction with the matter.

accuracy-The closeness of the result of a measurement to the true value of the quantity.

activity-See radioactivity.

aliquot-The quantity of sample being used for analysis that is representative of a larger quantity (e.g., 5 aliquots of 15 in the sample).

alkalinity-A measure of the buffering capacity of water; because $\mathrm{pH}$ has a direct effect on organisms as well as an indirect effect on the toxicity of certain other pollutants in the water, buffering capacity is important to water quality.

alpha particle-A positively charged particle emitted from the nucleus of an atom having the same charge and mass as that of a helium nucleus (two protons and two neutrons).

ambient air-The atmosphere around people, plants, and structures.

analytical detection limit-The lowest reasonably accurate concentration of an analyte that can be detected; this value varies depending on the method, instrument, and dilution used.

analyte-A constituent or parameter being analyzed.

anion-A negatively charged ion.

annealing-Maintenance of glass or metal at a specified temperature for a specific length of time followed by gradual cooling. This treatment removes internal strains and eliminates distortions and imperfections.

aquifer-A saturated, permeable geologic unit that can transmit significant quantities of water under ordinary hydraulic gradients.

aquitard-A geologic unit that inhibits the flow of water.

ash-Inorganic residue remaining after ignition of combustible substances.

assimilate-To take up or absorb.

atom-Smallest particle of an element capable of entering into a chemical reaction.

beta particle-A negatively charged particle emitted from the nucleus of an atom. It has a mass and charge equal to those of an electron.

biomass - The weight of any specific or general kind of organic matter, usually expressed per area or volume.

biota-The animal and plant life of a particular region considered as a total ecological entity. 
blank-A control sample that is identical, in principle, to the sample of interest, except that the substance being analyzed is absent. In such cases, the measured value or signal for the substance being analyzed is believed to be a result of artifacts. Under certain circumstances, that value may be subtracted from the measured value to give a net result reflecting the amount of the substance in the sample. The U.S. Environmental Protection Agency (EPA) does not permit the subtraction of blank results in EPA-regulated analyses.

calibration-Determination of variance from a standard of accuracy of a measuring instrument to ascertain necessary correction factors.

carcinogen-A cancer-causing substance.

cation-A positively charged ion.

CERCLA-reportable release-A release to the environment that exceeds reportable quantities as defined by CERCLA (Comprehensive Environmental Response, Compensation, and Liability Act).

chain of custody-A form that documents sample collection, transport, analysis, and disposal.

chemical oxygen demand-The quantity of oxidizable materials present in water; varies with water composition, concentrations of reagent, temperature, period of contact, and other factors.

chemical speciation-The occurrence of chemical elements in different forms or species (e.g., elemental, ionic, complexed), depending on environmental conditions.

chlorocarbons-Compounds of carbon and chlorine or carbon, hydrogen, and chlorine, such as carbon tetrachloride, chloroform, and tetrachloroethylene. They are among the most significant and widespread environmental contaminants and are classified as hazardous wastes. Chlorocarbons may have a tendency to cause detrimental effects, such as birth defects.

Ci-See curie.

closure-Control of a hazardous waste management facility under Resource Conservation and Recovery Act requirements.

COD—See chemical oxygen demand.

compliance-Fulfillment of applicable requirements of a plan or schedule ordered or approved by government authority.

concentration-The amount of a substance contained in a unit volume or mass of a sample.

conductivity-A measure of water's capacity to convey an electric current. This property is related to the total concentration of the ionized substances in water and the temperature at which the measurement is made.

confluence-The point at which two or more streams meet; the point where a tributary joins the main stream.

contamination-Deposition of unwanted material on the surfaces of structures, areas, objects, or personnel. 
control limits-A statistical tool used to define the bounds of virtually all values produced by a system in statistical control.

cosmic radiation-Ionizing radiation with very high energies, originating outside the earth's atmosphere. Cosmic radiation is one contributor to natural background radiation.

count-The signal that announces an ionization event within a counter; a measure of the radiation from an object or device.

counter-A general designation applied to radiation detection instruments or survey meters that detect and measure radiation.

counting geometry-A well-defined sample size and shape for which a counting system has been calibrated.

curie (Ci)-A unit of radioactivity. One curie is defined as $3.7 \times 10^{10}$ (37 billion) disintegrations per second. Several fractions and multiples of the curie are commonly used:

kilocurie ( $(\mathrm{CC})-10^{3} \mathrm{Ci}$, one thousand curies; $3.7 \times 10^{13}$ disintegrations per second. millicurie $(\mathrm{mCi})-10^{-3} \mathrm{Ci}$, one-thousandth of a curie; $3.7 \times 10^{7}$ disintegrations per second. microcurie $(\mu \mathrm{Ci})-10^{-6} \mathrm{Ci}$, one-millionth of a curie; $3.7 \times 10^{4}$ disintegrations per second. picocurie (pCi) $-10^{-12} \mathrm{Ci}$, one-trillionth of a curie; 0.037 disintegrations per second.

2,4-D-2,4-Dichlorophenoxyacetic acid.

daughter-A nuclide formed by the radioactive decay of a parent nuclide.

DCG-See derived concentration guideline.

decay, radioactive-The spontaneous transformation of one radionuclide into a different radioactive or nonradioactive nuclide or into a different energy state of the same radionuclide.

decontamination and decommissioning-See Environmental Restoration.

dense nonaqueous phase liquid (DNAPL) - The liquid phase of chlorinated organic solvents. These liquids are denser than water and include commonly used industrial compounds such as tetrachloroethylene and trichloroethylene.

derived concentration guideline (DCG)-The concentration of a radionuclide in air or water that under conditions of continuous exposure for one year by one exposure mode (i.e., ingestion of water, submersion in air, or inhalation) would result in either an effective dose equivalent of $0.1 \mathrm{rem}(1 \mathrm{mSv})$ or a dose equivalent of 5 rem $(50 \mathrm{mSv})$ to any tissue, including skin and the lens of the eye. The guidelines for radionuclides in air and water are given in DOE Order 5400.5.

desorption-The process of removing a sorbed substance by the reverse of adsorption or absorption.

detector-Material or device (instrument) that is sensitive to radiation and can produce a signal suitable for measurement or analysis. 
dilution factor-The mathematical factor by which a sample is diluted to bring the concentration of an analyte in a sample within the analytical range of a detector (e.g., $1 \mathrm{~mL}$ sample $+9 \mathrm{~mL}$ solvent $=1: 10$ dilution, or a dilution factor of 10$)$.

disintegration, nuclear-A spontaneous nuclear transformation (radioactivity) characterized by the emission of energy and/or mass from the nucleus of an atom.

dissolved oxygen-A desirable indicator of satisfactory water quality in terms of low residuals of biologically available organic materials. Dissolved oxygen prevents the chemical reduction and subsequent leaching of iron and manganese from sediments.

DNAPL $\_$See dense nonaqueous phase liquid.

dose-The energy imparted to matter by ionizing radiation. The unit of absorbed dose is the rad, equal to 0.01 joules per kilogram in any medium.

absorbed dose-The quantity of radiation energy absorbed by an organ divided by the organ's mass. Absorbed dose is expressed in units of rad (or gray) (1 rad $=0.01 \mathrm{~Gy}$ ).

dose equivalent-The product of the absorbed dose (rad) in tissue and a quality factor. Dose equivalent is expressed in units of rem (or sievert) $(1 \mathrm{rem}=0.01 \mathrm{~Sv})$.

committed dose equivalent-The calculated total dose equivalent to a tissue or organ over a 50-year period after known intake of a radionuclide into the body. Contributions from external dose are not included. Committed dose equivalent is expressed in units of rem (or sievert).

committed effective dose equivalent-The sum of the committed dose equivalents to various tissues in the body, each multiplied by the appropriate weighting factor. Committed effective dose equivalent is expressed in units of rem (or sievert).

effective dose equivalent-The sum of the dose equivalents received by all organs or tissues of the body after each one has been multiplied by an appropriate weighting factor. The effective dose equivalent includes the committed effective dose equivalent from internal deposition of radionuclides and the effective dose equivalent attributable to sources external to the body.

collective dose equivalent/collective effective dose equivalent-The sums of the dose equivalents or effective dose equivalents of all individuals in an exposed population within a 50 -mile $(80-\mathrm{km})$ radius expressed in units of person-rem (or person-sievert). When the collective dose equivalent of interest is for a specific organ, the units would be organ-rem (or organ-sievert). The 50-mile distance is measured from a point located centrally with respect to major facilities or DOE program activities.

dosimeter-A portable detection device for measuring the total accumulated exposure to ionizing radiation.

dosimetry-The theory and application of principles and techniques involved in the measurement and recording of radiation doses. Its practical aspect is concerned with using various types of radiation instruments to make measurements.

downgradient-In the direction of decreasing hydrostatic head.

downgradient well-A well that is installed hydraulically downgradient of a site and that may be capable of detecting migration of contaminants from a site.

drinking water standards (DWS)-Federal primary drinking water standards, both proposed and final, as set forth by the U.S. Environmental Protection Agency. 
DWS-See drinking water standards.

effluent-A liquid or gaseous waste discharge to the environment.

effluent monitoring-The collection and analysis of samples or measurements of liquid and gaseous effluents for purposes of characterizing and quantifying the release of contaminants, assessing radiation exposures of members of the public, and demonstrating compliance with applicable standards.

Environmental Restoration-A DOE program that directs the assessment and cleanup of its sites (remediation) and facilities (decontamination and decommissioning) contaminated with waste as a result of nuclear-related activities.

equipment blank-A sample container of deionized water that has been pumped through or has filled a sampling device (e.g., well pump bailer). Laboratory analysis of the blank can identify potential contaminants in water, sample container, or analytical equipment.

exposure (radiation) - The incidence of radiation on living or inanimate material by accident or intent. Background exposure is the exposure to natural background ionizing radiation. Occupational exposure is that exposure to ionizing radiation that takes place at a person's workplace. Population exposure is the exposure to the total number of persons who inhabit an area.

external radiation-Exposure to ionizing radiation when the radiation source is located outside the body.

fauna-The population of animals at a given area, environment, formation, or time span.

fecal coliform-The coliform group comprises all of the aerobic, non-spore-forming, rod-shaped bacteria. The test determines the presence or absence of coliform organisms.

field blank-A sample container of deionized water generated by filling the sample container at the sample location and treated as a groundwater sample.

fixed residue-Material left in the vessel after evaporating a water sample and its subsequent ashing in an oven at a high temperature. Waters yielding considerable residue are generally inferior with respect to palatability, or they may induce an unfavorable physiological reaction in the transient consumer.

flora-The population of plants at a given area, environment, formation, or time span.

formation-A mappable unit of consolidated or unconsolidated geologic material of a characteristic lithology or assemblage of lithologies.

gamma ray-High-energy, short-wavelength electromagnetic radiation emitted from the nucleus of an excited atom. Gamma rays are identical to $\mathrm{X}$ rays except for the source of the emission.

gamma spectrometry-A system consisting of a detector, associated electronics, and a multichannel analyzer that is used to analyze samples for gamma-emitting radionuclides.

Gaussian puff/plume model-A computer-simulated atmospheric dispersion of a release using a Gaussian (normal) statistical distribution to determine concentrations in air. 
Geiger-Mueller (GM) counter-A highly sensitive, gas-filled radiation detector that operates at voltages sufficiently high to produce ionization. The counter is used primarily in the detection of gamma radiation and beta emission. It is named for Hans Geiger and W. Mueller, who invented it in 1928.

grab sample-A sample collected instantaneously with a glass or plastic bottle placed below the water surface to collect surface water samples (also called dip samples).

groundwater, unconfined-Groundwater exposed to the unsaturated zone.

half-life, radiological-The time required for half of a given number of atoms of a specific radionuclide to decay. Each nuclide has a unique half-life.

halogenated compound-An organic compound bonded with one of the five halogen elements (astatine, bromine, chlorine, fluorine, and iodine).

halomethane-Any compound that includes a methane group $\left(\mathrm{CH}_{3}\right)$ bonded to a halogen element (astatine, bromine, chlorine, fluorine, or iodine).

heavy water-Water in which the molecules contain oxygen and deuterium, an isotope of hydrogen that is heavier than ordinary hydrogen.

hydrology-The science dealing with the properties, distribution, and circulation of natural water systems.

hydrogeology-Hydraulic aspects of site geology.

in situ-In its original place; field measurements taken without removing the sample from its origin; remediation performed while groundwater remains below the surface.

internal blank-Deionized water sample generated by the laboratory; an internal blank is analyzed with each batch of samples as an in-house check of analytical procedures and equipment.

internal dose factor-A factor used to convert intakes of radionuclides to dose equivalents.

internal radiation-Occurs when natural radionuclides enter the body by ingestion of.foods, milk, or water or by inhalation. Radon is the major contributor to the annual dose equivalent for internal radionuclides.

ion-An atom or compound that carries an electrical charge.

ion exchange-A process in which a solution containing soluble ions is passed over a solid ion exchange column that removes the soluble ions by exchanging them with labile ions from the surface of the column. The process is reversible so that the trapped ions are removed from the column and the column is regenerated.

irradiation-Exposure to radiation.

isotopes-Forms of an element having the same number of protons but differing numbers of neutrons in their nuclei. 
long-lived isotope-A radionuclide that decays at such a slow rate that a quantity of it will exist for an extended period (half-life is greater than three years).

short-lived isotope-A radionuclide that decays so rapidly that a given quantity is transformed almost completely into decay products within a short period (half-life is two days or less).

laboratory blank-See internal blank.

LLD-See lower limit of detection.

lower limit of detection (LLD)-The smallest concentration or amount of analyte that can be reliably detected in a sample at a $95 \%$ confidence level.

macroinvertebrates-A size-based classification used for a variety of insects and other small invertebrates; as defined by the U.S. Environmental Protection Agency, those organisms that are retained by a No. 30 (590 micron) U.S. standard sieve.

maximally exposed individual-A hypothetical individual who remains in an uncontrolled area and would, when all potential routes of exposure from a facility's operations are considered, receive the greatest possible dose equivalent.

mean relative difference (MRD)—a percentage error based on statistical analysis.

mercury-A silver-white liquid metal solidifying at $-38.9^{\circ} \mathrm{C}$ to form a tin-white, ductile, malleable mass. It is widely distributed in the environment and biologically is a nonessential or nonbeneficial element. Human poisoning caused by this highly toxic element has been clinically recognized.

microbes-Microscopic organisms.

migration-The transfer or movement of a material through air, soil, or groundwater.

milliroentgen (mR)-A measure of X-ray or gamma radiation. The unit is one-thousandth of a roentgen.

minimum detectable concentration-The smallest amount or concentration of a radionuclide that can be distinguished in a sample by a given measurement system at a preselected counting time and at a given confidence level.

monitoring-Process whereby the quantity and quality of factors that can affect the environment or human health are measured periodically to regulate and control potential impacts.

MRD-See mean relative difference.

mrem-The dose equivalent that is one-thousandth of a rem.

natural radiation-Radiation from cosmic and other naturally occurring radionuclide (such as radon) sources in the environment.

nonstochastic effects-Biological effects in which the severity in affected individuals varies with the magnitude of the dose above a threshold. 
nuclide-An atom specified by its atomic weight, atomic number, and energy state. A radionuclide is a radioactive nuclide.

outcrop-A place where groundwater is discharged to the surface. Springs, swamps, and beds of streams and rivers are the outcrops of the water table.

outfall-The point of conveyance (e.g., drain or pipe) of wastewater or other effluents into a ditch, pond, or river.

part per billion (ppb)—A unit measure of concentration equivalent to the weight/volume ratio expressed as $\mathrm{g} / \mathrm{L}$ or $\mathrm{ng} / \mathrm{mL}$.

part per million (ppm)-A unit measure of concentration equivalent to the weight/volume ratio expressed as $\mathrm{mg} / \mathrm{L}$.

person-rem-Collective dose to a population group. For example, a dose of 1 rem to 10 individuals results in a collective dose of 10 person-rem.

$\mathrm{pH}-\mathrm{A}$ measure of the hydrogen ion concentration in an aqueous solution. Acidic solutions have a $\mathrm{pH}$ from 0 to 6 , neutral solutions have a $\mathrm{pH}$ equal to 7 , and basic solutions have a $\mathrm{pH}>7$.

piezometer-An instrument used to measure the potentiometric surface of the groundwater; also, a well designed for this purpose.

point of compliance-A vertical surface located at the hydraulically downgradient limit of the waste management area that extends down into the uppermost aquifer underlying the regulated units.

population dose commitment-See collective dose equivalent.

ppb-See part per billion.

ppm-See part per million.

precision-The closeness of approach of a value of similar or replicate results to a common value in a series of measurements.

process water-Water used within a system process.

process sewer-Pipe or drain, generally located underground, used to carry off process water or waste matter.

purge-To remove water before sampling, generally by pumping or bailing.

QA-See quality assurance.

QC-See quality control.

quality assurance (QA) - Any action in environmental monitoring to ensure the reliability of monitoring and measurement data.

\section{G-8 Glossary}


quality control (QC)-The routine application of procedures within environmental monitoring to obtain the required standards of performance in monitoring and measurement processes.

quality factor-The factor by which the absorbed dose (rad) is multiplied to obtain a quantity that expresses, on a common scale for all ionizing radiation, the biological damage to exposed persons. It is used because some types of radiation, such as alpha particles, are more biologically damaging than others.

rad-The unit of absorbed dose deposited in a volume of material.

radiation detection instruments-Devices that detect and record the characteristics of ionizing radiation.

radioactivity - The spontaneous emission of radiation, generally alpha or beta particles or gamma rays, from the nucleus of an unstable isotope.

radioisotopes-Radioactive isotopes.

radionuclide—An unstable nuclide capable of spontaneous transformation into other nuclides by changing its nuclear configuration or energy level. This transformation is accompanied by the emission of photons or particles.

RCRA-See Resource Conservation and Recovery Act.

reagent-Any substance used in a chemical reaction to detect or measure another substance or to convert one substance into another by means of the reaction that it causes.

reagent blank-A control sample used to determine the background of each reagent or solvent used in a given method of analysis. They are composed of all constituents that will contact the sample except the sample itself.

reclamation-Recovery of wasteland, desert, etc., by ditching, filling, draining, or planting.

reference material-A material or substance with one or more properties that is sufficiently well established and used to calibrate an apparatus, to assess a measurement method, or to assign values to materials.

release-Any discharge to the environment. Environment is broadly defined as any water, land, or ambient air.

rem-The unit of dose equivalent (absorbed dose in rads $\times$ the radiation quality factor). Dose equivalent is frequently reported in units of millirem (mrem), which is one-thousandth of a rem.

remediation-The correction of a problem. See Environmental Restoration.

replicate-In groundwater monitoring, a second sample from the same well taken at the same time as the primary sample and sent to the same laboratory for analysis.

replicate result-The analytical result of a blind replicate sample.

resin-An organic polymer used as an ion-exchange material. 
Resource Conservation and Recovery Act (RCRA)—Federal legislation that regulates the transport, treatment, and disposal of solid and hazardous wastes.

RFI Program-RCRA Facility Investigation Program; U.S. Environmental Protection Agency-regulated investigation of a solid waste management unit with regard to its potential impact on the environment.

roentgen-A unit of exposure from $\mathrm{X}$ or gamma rays. One roentgen equals $2.58 \times 10^{-4}$ coulombs per kilogram of air.

routine radioactive release-A planned or scheduled release of radioactivity to the environment.

screen zone-In well construction, the section of a formation that contains the screen, or perforated pipe, that allows water to enter the well.

seepage basin-An excavation that receives wastewater. Insoluble materials settle out on the floor of the basin, and soluble materials seep with the water through the soil column where they are removed partially by ion exchange with the soil. Construction may include dikes to prevent overflow or surface runoff.

self-absorption-Absorption of radiation by the sample itself, preventing detection by the counting instrument.

sensitivity-The capability of methodology or instruments to discriminate between samples with differing concentrations or containing varying amounts of an analyte.

settleable solids-Material settling out of suspension within a defined period.

settling basin-A temporary holding basin (excavation) that receives wastewater that is subsequently discharged.

sidegradient well-A well that intercepts groundwater flowing next to a site; a sidegradient well is located neither upgradient nor downgradient to the monitored site.

sievert (Sv)-The SI (International System of Units) unit of dose equivalent; $1 \mathrm{~Sv}=100 \mathrm{rem}$.

slurry-A suspension of solid particles (sludge) in water.

Solid Waste Disposal Facility (SWDF)—A place for burying unwanted radioactive material to prevent escape of radioactivity. The surrounding water acts as a shield. Such material is placed in watertight, noncorrodible containers so that it cannot leach out and invade underground water.

source-A point or object from which radiation or contamination emanates.

source check-A radioactive source with a known amount of radioactivity used to check the performance of the radiation detector instrument.

source term-Quantity of radioactivity released in a set period of time that is traceable to the starting point of an effluent stream or migration pathway.

specific conductance-The ability of water to conduct electricity; this ability varies in proportion to the amount of ionized minerals in the water.

\section{G-10 Glossary}


spike-The addition of a known amount of reference material containing the analyte of interest to a blank sample.

split sample-Two samples from the same well taken at the same time and sent to two different laboratories for analysis.

stable-Not radioactive or not easily decomposed or otherwise modified chemically.

stack-A vertical pipe or flue designed to exhaust airborne gases and suspended particulate matter.

standard deviation-An indication of the dispersion of a set of results around their average.

standard reference material (SRM)-A reference material distributed and certified by the National Institute of Standards and Technology.

stochastic effects-Biological effects the probability of which, rather than the severity, is a function of the magnitude of the radiation dose without threshold (i.e., stochastic effects are random in nature).

storm water runoff-Surface streams that appear after precipitation.

strata-Beds, layers, or zones of rocks.

substrate-The substance, base, surface, or medium in which an organism lives and grows.

sulfate-Compound containing the $-\mathrm{SO}_{4}$ group (e.g., $\mathrm{Na}_{2} \mathrm{SO}_{4}$ ); widely distributed in nature and may be present in natural waters in concentrations ranging from a few to several thousand milligrams per liter.

supernatant-The portion of a liquid above settled materials in a tank or other vessel.

surface water-All water on the surface of the earth, as distinguished from groundwater.

suspended solids—Mixture of fine, nonsettling particles of any solid within a liquid or gas.

Sv-See sievert.

SWDF-See Solid Waste Disposal Facility.

tank farm-An installation of interconnected underground tanks for storage of high-level radioactive liquid wastes.

terrestrial radiation-Ionizing radiation emitted from radioactive materials, primarily ${ }^{40} \mathrm{~K}$, thorium, and uranium, in the earth's soils. Terrestrial radiation contributes to natural background radiation.

thermoluminescent dosimeter (TLD)—A device used to measure external gamma radiation.

TLD-See thermoluminescent dosimeter. 
total activity-The total quantity of radioactive decay particles that are emitted from a sample.

total dissolved solids-Dissolved solids and total dissolved solids are terms generally associated with freshwater systems and consist of inorganic salts, small amounts of organic matter, and dissolved materials.

total organic halogens-A measure of the total concentration of organic compounds that have one or more halogen atoms.

total solids-The sum of total dissolved solids and suspended solids.

total suspended particulates-Refers to the concentration of particulates in suspension in the air irrespective of the nature, source, or size of the particulates.

transuranic waste-Solid radioactive waste containing primarily alpha-emitting elements heavier than uranium.

transuranic elements-Elements with higher atomic weights than uranium; all 13 known transuranic elements are radioactive and are produced artificially.

tritium $\left({ }^{3} \mathbf{H}\right)$-The hydrogen isotope with one proton and two neutrons in the nucleus. It emits a low-energy beta particle (0.0186 MeV max) and has a half-life of 12.5 years.

t-test-Statistical method used to determine if the means of groups of observations are equal.

turbidity-A measure of the concentration of sediment or suspended particles in solution.

upgradient—In the direction of increasing hydrostatic head.

vadose zone-Soil zone located above the water table.

variation-The divergence in the structural or functional characteristics of an organism from those considered typical of the group to which it belongs.

volatile organic compounds-1,1,1-TCA, perclene, and triclene are common names for trichloroethane, tetrachloroethylene, and trichloroethylene, respectively. Used in many processes, the levels of these carcinogenic compounds must be kept to a minimum. They are measured by volatile organic analyses content.

watershed-The region draining into a river, river system, or body of water.

wetlands-A lowland area, such as a marsh or swamp, inundated or saturated by surface or groundwater sufficiently to support hydrophytic vegetation typically adapted to life in saturated soils.

wind rose-A diagram in which statistical information concerning direction and speed of the wind at a location is summarized.

\section{G-12 Glossary}




\section{Internal Distribution}

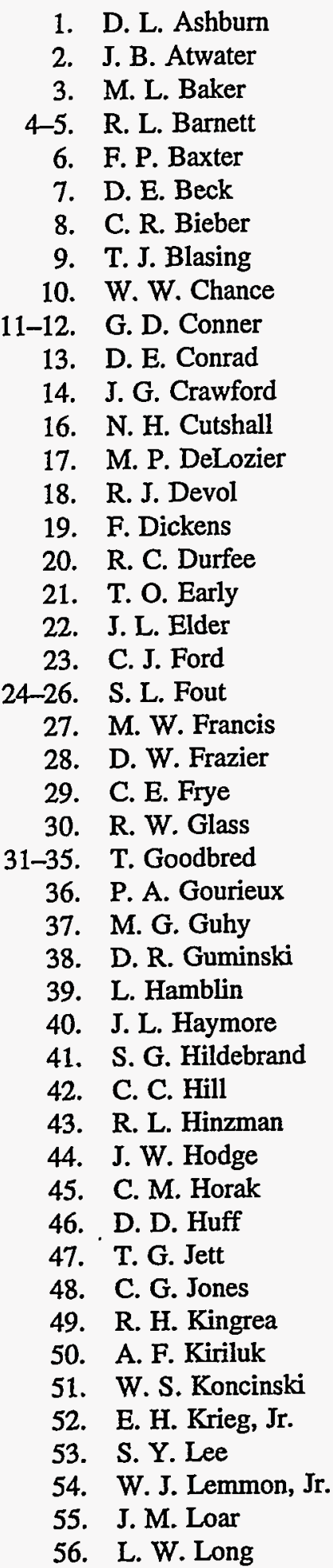

57. A. P. Malinauskas

58. W. D. Malis

60. F. K. Martin

61. J. C. Massey

62 T. McDermott

63. J. G. McDonald

64. L. W. McMahon

65. S. A. Meacham

66. L. J. Mezga

67. J. L. Miranda

68. G. L. Murphy

69. J. B. Murphy

70-99. S. C. Newman

100. C. E. Nix

101. F. R. O'Donnell

102. T. W. Olin

103. S. E. Payne

104. M. J. Peterson

105. G. V. Pierce

106. J. E. Powell

107. R. E. Pudelek

108. D. E. Ray

109. R. Richmond

110. D. L. Roberts

111. J. L. Roberts

112. J. G. Rogers

113. J. E. Rushton

114. G. E. Rymer

115. L. B. Ryon

116. J. Sherwin

117. E. M. Schilling

118. L. G. Shipe

119. S. P. N. Singh

120. N. L. Sinor

121. E. L. Smith, Jr.

122-123. M. C. Smith

124. R. H. Snyder

125. M. L. Socolof

126. G. R. Southworth

127. P. A. Sperling

128. D. L. Stansberry

129. L. Stenzel

130. L. E. Stokes

131. S. H. Stow

132. W. D. Strunk

133. F. G. Taylor, Jr.

134. T. D. Taylor 
135. J. H. Turner

136. W. Walker

137. C. W. Walter

138. C. W. Weber

139. L. Welch

140-189. D. C. West

190. D. A. White

191. M. G. White

192. R. K. White

193. J. K. Williams

194. W. R. Williams

195. S. L. Winters

196. ORNL Central Research Library

197. DOE K-25 Site Office

197-217. DOE Portsmouth Site Office
218. DOE Y-12 Site Office

219. ORNL ESD Library

220-222. ORNL Laboratory Records

223. ORNL Laboratory Records--RC

224. ORNL Patent Section

225. ORNL Y-12 Technical Library

226. PGDP Library

227. Portsmouth Administrative Records

228. Portsmouth Central Files

229. Portsmouth Records Management

230. Portsmouth Technical Library

231. Portsmouth Environmental Management-RC

232. K-25 CEP Document Center

233. K-25 Site Library

\section{External Distribution}

234. Office of Assistant Manager for Energy Research and Development, U.S. Department of Energy Oak Ridge Operations, P.O. Box 2001, Oak Ridge, TN 37831-8600.

235-236. Office of Scientific and Technical Information, P.O. Box 62, Oak Ridge, TN 37831.

237-333. This report is distributed widely by the Department of Energy's, Oak Ridge Operations Office to local, state, and federal government agencies; the Congress; the public; and the news media. 